ENTRE EISENMAN, BERLIM E O MEMORIAL 
JOÃO CARLOS AMARAL YAMAMOTO

\section{ENTRE EISENMAN, BERLIM E O MEMORIAL}

DISSERTAÇÃO APRESENTADA À FACULDADE

DE AROUITETURA E URBANISMO DA

UNIVERSIDADE DE SÃO PAULO PARA

OBTENÇÃO DO TÍTULO DE MESTRE EM

AROUITETURA E URBANISMO

área de concentração

DESIGN E AROUITETURA

orientador

PROF. DR. GIORGIO GIORGI JR.

são paulo, 2014 
fins de estudo e pesquisa, desde que citada a fonte.

e-mail do autor: joaoyamamoto@gmail.com

Yamamoto, João Carlos Amaral

Y19E Entre Eisenman, Berlim e o Memorial João Carlos Amaral Yamamoto. --São Paulo, 2014.

340 p. : il.

Dissertação (Mestrado - Área de Concentração: Design e Arquitetura) - FAUUSP.

Orientador: Giorgio Giorgi Junior

1.Arquitetura moderna - Berlim 2. Semiótica da Arquitetura 3. Projeto de Arquitetura 4.Artes 5.Escultura 6.Monumentos 7.Memórias 8.Holocausto Judeu

9.Eisenman, Peter, 1932 - I.Título
Muitas pessoas e entidades me ajudaram de diversas maneiras ao longo de todo o processo. As que aqui estão listadas e àquelas que, por um acidente, não foram incluídas, meus sinceros agradecimentos. Ao CNPq e à FAU pela concessão da bolsa de pesquisa que garantiu a dedicação necessária para a realização deste trabalho.

Ao Giorgio, pela orientação, pelas conversas, cafés e cervejas, pela oportunidade de acompanhá-lo em sala de aula durante um semestre e, sobretudo, pela enorme confiança depositada em mim, desde o processo de seleção (com uma proposta tão nebulosa quanto aquela) até os últimos dias de fechamento.

À Irene Machado, pelas aulas e conversas que influíram de maneira decisiva na minha pesquisa e aos colegas do Grupo de Pesquisa Semiótica da Comunicação.

Às professoras Lucrécia Ferrara e Irene Machado, pelas contribuições na Banca de Qualificação, que ao trazerem o meu texto para um terreno sólido, permitiram a caminhada.

Ao Canadian Centre for Architecture (CCA) e à Renata Guttman pelo acesso ao acervo do projeto de Eisenman; à Georgia Lobo pela gentileza de dedicar suas horas a um desconhecido para pesquisa e fotografar o material; ao Adamo Cicchi, da Fundação Memoria dos Judeus Assassinados da Europa, pela cessão da publicação de fotos da construção. 
Aos amigos Gabriel Pedrosa, pelas conversas, leituras e sugestões, Gabriela Tamari, pela ajuda, sugestões e empréstimo da pequena câmera automática, João Sodré, pelas leituras e referências, Max Gheringuer, pelo empréstimo de longuíssimo prazo dos mapas e fotos aéreas de Berlim, e Guy Hunt, pela tradução do resumo.

Ao professor, Fernando Vázquez, pelas leituras e incentivo para a publicação do artigo; aos professores José Lira, Luís Antônio Jorge, Alvaro Puntoni, Carlos Ferrata e Milton Braga, pelas cartas de recomendação e documentos para o processo de seleção do mestrado e da bolsa; aos professores Vicente Gil, pela oportunidade da monitoria de graduação, e Fernando Franco, pelas conversas iniciais.

Aos amigos Eduardo Gurian, Giovanni Meirelles e Gustavo Delonero, pelas preciosas referências; Vito Macchione, pelas referências e parcerias nas experiências espaciais e acústicas que, de alguma maneira, fizeram parte do raciocínio deste trabalho; André Nunes, Andrei Almeida, Annette Gorenstein, Claudio Dedecca, Carolina Leonelli, Carolina Heldt, Gil Tokio, José Paulo Gouvêa, Juliana Braga, Paula Gabbai, Rodrigo Sommer e Thiago Mendes, pelas diversas contribuições. Aos amigos do conjunto 53, pelo empréstimo da mesa nos delirantes dias quentes do começo de fevereiro.

Aos meus pais e irmãos, pelo apoio incondicional e tudo mais..

À Paula, companheira com quem me perco e me acho, nessa e em todas as viagens. Meu mar. Foi para ela que fiz este trabalho.

\section{RESUMO}

A pesquisa lançou um olhar sobre a produção arquitetônica de Peter Eisenman e sobre a cidade de Berlim, buscando centrar-se na análise de uma obra específica, o Memorial dos Judeus Assassinados da Europa. 0 texto construído é uma reunião de instantâneos de percurso, de fragmentos de uma narrativa imaginada e interpretada pelo verbal. Tentando construir uma análise que contemplasse de alguma maneira a dimensão da experiência da obra, foi promovido o cruzamento com comentários e análises escritas em outros momentos com reflexões feitas a partir de achados de pesquisa, com recortes de textos e imagens e desenhos analíticos feitos ao longo do trabalho. Assim, o conjunto de três capítulos procura desenhar um percurso análogo ao desenvolvido ao longo da pesquisa, procurando permanecer atento ao suporte texto/imagem de uma dissertação e condensando o processo de três anos no relato ficcional de uma jornada de um dia. No primeiro capítulo é feita uma espécie de panorâmica cronológica da obra de Eisenman que, no entanto, não conta a sua história, mas a do pesquisador seguindo a trilha deixada pelo arquiteto. No segundo capítulo a jornada ganha tempo e espaço com a sequencia que narra a chegada à cidade de Berlim e o percurso até o Memorial dos Judeus Assassinados da Europa, cuja análise é feita no terceiro capítulo.

Palavras-chave: Arquitetura; semiótica da arquitetura; projeto diagrama; Peter Eisenman; Berlim; arte; escultura; monumento; memória; holocausto. 
This research takes an overview of the architectural output of Peter Eisenman and more generally, the city of Berlin. The research then focusses on an analysis of a single specific work, the Memorial to the Murdered Jews of Europe.

The text itself is constructed from moments in a perambulation of the work and fragments of an imagined narrative. As an attempt to construct an analysis which contemplates the physical experience of the work, this method interlaces commentaries and analyses made at different times, reflections on findings of the research and snippets of text, images and drawings made during the course of the research As a whole, the three chapters seek to illustrate the route taken during the research. Whilst remaining aware of the need to support the text/images of a dissertation, the text aims to condense the process of three years of research into the fictional story of a single day.

The first chapter gives a chronological overview of the works of Eisenman. This is not recounted as a history of the works, but as an account of the researcher following the trail left by the architect. The second chapter gains time and space with a sequence that narrates the arrival of the researcher in Berlin and the journey to the Memorial to the Murdered Jews of Europe. The analysis of the Memorial itself is contained in the third chapter.

\section{Keywords:}

Architecture, architectural semiotics, project, diagram, Peter Eisenman, Berlin, art, sculpture, monument, memorial, holocaust. 
PRIMEIRO CAPÍTULO: NA TRILHA DE EISENMAN 27 TRAJETÓRIA 38

SEGUNDO CAPÍTULO: CAMINHADA EM BERLIM

LASTRO

APROXIMAÇÃO 124

CABOTAGEM 136

TERCEIRO CAPITULO: NO MEMORIAL

MARGEM

MERGULHO

DERIVA

212

SUPERFICIE

266

CONSIDERAÇÕES FINAIS

REFERÊNCIAS BIBLIOGRÁFICAS 
Disse Le Corbusier que "a arquitetura é o jogo sábio, correto e magnífico dos volumes reunidos sob a luz"1. A afırmação, disparada como tiro de alerta logo no início do célebre texto para anunciar as suas proposições aos arquitetos, não apenas revela e apóia uma concepção especifica de arquitetura como também indica uma chave de leitura, aponta para uma forma de pensar e analisar as suas obras. Dos três "lembretes aos arquitetos" que seguem a afırmação - o volume, a superfície e a planta -, os dois primeiros referem-se diretamente à percepção da manifestação visual da construção, ou seja, às qualidades captadas e interpretadas através das capacidades perceptivas do olho no momento de interação com a obra. Já a última, a planta aponta para o momento de concepção, para o pensamento a respeito de algo que ainda não existe fisicamente, para uma projeção no futuro ${ }^{2}$. A planta, como ferramenta analítica que cria uma espécie de visão racionalizada do espaço, organiza plasticamente os volumes e superfícies que, construídos, serão atingidos pela luz e apreendidos pelo olho. Sendo assim, a visualidade - tanto da arquitetura construída, como da planta - é para Le Corbusier o ponto central no pensamento sobre a arquitetura e, para nós, fundamental para analisarmos a sua obra.

Mas, ao olharmos para a infınidade de leituras feitas sobre o conjunto de realizações do arquiteto franco-suiço, encontramos não apenas análises que às vezes deixam a visualidade em papel secundário, como também algumas que simplesmente a ignoram. Além de leituras feitas a partir da expressão plástica, nos deparamos com outras que procuram localizar as obras dentro de uma tradição e dentro do percurso desenvolvido pela disciplina, que buscam compreendê-las a

1. "A arquitetura é o jogo säbio, correto e magnifico dos volumes reunidos sob a luz. Nossos olhos são eitos para ver formas sob a luz; as sombras e os claros revelam as formas (...)". LE CORBUSIER. Por uma arquitetura. São Paulo, Perspectiva, 1977, p.13. 
partir dos processos produtivos, das relações de trabalho no canteiro, da tecnologia da construção, que exploram o seu funcionament como estrutura ou como organização programática, que avaliam o seu desempenho funcional, ergonômico, térmico, energético, e ainda, com outras tantas que partem das relações com a história da cultura em que foram produzidas, do lugar em que se realizaram, da vida do arquiteto que as projetou ou das relações sociais em que foram envolvidas. E, apesar da facilidade com que chegamos àquela conclusão e da óbvia ligação entre a idéia de arquitetura e a visão, não conseguimos deixar de considerar relevantes muitas das observações encontradas.

Qualquer um desses entendimentos, entretanto, se transformado em explicação ou definição, potencialmente cai por terra ou ao menos tem a sua estrutura abalada quando confrontado com a experiência da obra ou com outra análise feita sobre bases que são estranhas a ele. Qualquer associação é potencialmente falível. Qualquer retrato feito é distorcido se mudarmos o ponto de vista. E mais do que isso, como observou Décio Pignatari, qualquer leitura feita sobre manifestações como as da arquitetura, enfrentará de antemão um limite que diz respeito à própria natureza do seu objeto de leitura.

“O mundo das formas - visuais, sonoras, palativas, hápticas, olfativas - é um mundo icônico. Nas relações dialéticas entre o qualis e o quantum, aqui, sobreleva o qualis, ou a 'qualidade de um sentimento', como quer Peirce. Ao analisarmos o estilo barroco, por exemplo, podemos verbalizar aquilo que consideramos como suas principais características: nesta forma de generalização simbólica (verbal), sobreleva o quantum. Mas a informação principal, o qualis do barroco, aquilo que faz do barroco um sistema formal único, não pode ser verbalizado. um rema que só pode ser captado ou capturado por apreensão direta. É como procede o artista, diferentemente do analista, do critico, do historiador; a função destes, justamente, é a de sitiar, acuar o objeto até os limites sitiáveis e acuáveis (além dos quais é inalcançável)". ${ }^{3}$
Mesmo se falarmos apenas dos pontos do texto de Le Corbusier - a planta, a superfície e o volume -, algumas questões além da visualidade poderiam ser consideradas. A planta não é somente o esquema gerador, a inscrição de uma regra na superfície do solo ou a base de onde se eleva uma estrutura, não é apenas o meio através do qual o arquiteto confere ordem ao jogo de volumes e superfícies que atingem o "olho do espectador". A planta é também um elo com a tradição em arquitetura, é parte de um sistema de projeção ortogonal, estabelece relações com disciplinas como a álgebra e a geometria, e é uma ferramenta de pensamento que, em função de suas próprias qualidades, maneiras de operar e traduzir, conduz os resultados de uma maneira muito específica. A superfície e o volume, por sua vez, não são apenas imagem, não são apenas luz refletida pelo plano incidindo na retina, mas também som, textura, temperatura, ou ainda, a maneira como o indivíduo caminha (e o tempo dessa caminhada), independentemente de possuir a faculdade da visão.

Uma construção não é percebida e entendida como arquitetura apenas pela sua dimensão visual, mas pelo cruzamento e, fundamentalmente, pela percepção de relação entre as diversas qualidades (visuais, sonoras, táteis, olfativas), as diversas associações feitas a partir delas e as hipóteses e conclusões a que se chega nos raciocínios operados na tentativa de sua compreensão. A arquitetura é linguagem e, como organização de informação construída não apenas a partir de percepções visuais, mas multisensoriais, produz mensagens (e gera raciocínios) que não dependem exclusivamente do código visual. Parafraseando Iúri Lotman ${ }^{5}$, em uma obra de arquitetura tudo é mensagem. A apreensão da obra de arquitetura entendida como processo comunicacional abre caminho para a possibilidade de entendermos essas realizações como textos. ${ }^{6}$

3. PIGNATARI, Décio. Semiótica da arte e da arquitetura. São Paulo, Cultrix, 1981, p.111

4. LE CORBUSIER. Por uma arquitetura. São Paulo, Perspectiva, 1977, p.27.

5. LOTMAN, I. M. A estrutura do texto artístico. Lisboa, Editorial Estampa, 1978, p.49. 
Materializada, percebida e interpretada, a obra de arquitetura, ao mesmo tempo em que se dá como realidade espacial e como oferta aos sentidos, pode estabelecer um diálogo com outras disciplinas ${ }^{7}$ dependendo assim de outros códigos, com realizações e projeções anteriores e com o processo de pensamento percorrido pelo arquiteto durante o projeto. Assim como haviam sido os inúmeros croquis desenhos técnicos, textos, modelos físicos, todas as ferramentas que participaram daquele processo, a obra construída se estabelece como mais um elemento de um raciocínio arquitetônico ${ }^{8}$ e oferece para aquele que percorre essa trilha - seja ele o arquiteto que a projetou ou simplesmente aquele que se propôs essa tarefa - elementos que não poderiam ser oferecidos de outra maneira. A obra de arquitetura, ao mesmo tempo em que é fenômeno, é também a formalização de um diálogo com toda a sequência de obras e proposições realizadas anteriormente (a tradição em arquitetura), com a natureza dos materiais que aglutinados lhe dão consistência, com todos os procedimentos e ações executadas no processo de construção (as marcas deixadas pelas mãos e pelas máquinas na matéria), com os suportes e técnicas de representação e com a aquilo que todos esses elementos, colocados em relação uns aos outros, provocaram a cada etapa do processo.

6. "Se a arte é meio de comunicação particular, uma linguagem organizada de forma particular (meorganizado que serve de meio de comunicacão e que utiliza signos') então as obras de arte - ou seja, as comunicaçōes nesta linguagem - podem ser consideradas textos". LOTMAN, I. M. A estrutura do texto artístico. Lisboa, Editorial Estampa, 1978, p.32.

7. Na prova didática do concurso para professor titular da Fauusp, João Batista Vilanova Artigas responde interessante ( ) como esse artista malicioso não aceita a relacão imediata da passagem do apoio e da força de gravidade para sustentar a coluna a não ser por meio dessa forma dialética negativa da própría força inexorável da gravidade, por meio do capitel. Nesse ponto ele fala uma outra linguagem. Nessa altura, o que o arquiteto diz é: 'Não tenho nada a ver com a força da gravidade, é um obstáculo absurdo. que a ideia, o pensamento a sensibilidade podem negar dialeticamente. Enegam-no cantando! Quer diz uma coisa dessas ja esta lendo na arquitetura, ou escutando a linguagem da forma. E, quando falo seus edifíios, por mais modestos que pOSsam ser, terha uma coise a dizer( )" ARTIGAS, João Batista Vilanova. Caminhos da arquitetura. São Paulo, Cosac Naify, 2004, p.224.
Projeto, construção e obra realizada guardam, como arquitetura, embora de forma precária e totalmente dependente dos repertórios de seus interpretantes, uma íntima e inextirpável ligação.

Independentemente dos repertórios e das mais variadas associações feitas - pois, "caindo na vida", a obra de arquitetura foge do controle do seu criador e abre-se à infınidade de associações e significações possíveis, aos mais diversos usos e apropriações -, se falarmos dessas realizações como obras de arquitetura (e delas como textos), o projeto e a construção deverão ser tratados como o momento em que são pensadas as relações entre aqueles elementos, como um momento de notação de mensagens, de operação nos códigos (arquitetônico, tecnológico, visual, verbal, etc.), muito embora, como já dito, além da impossibilidade de previsão segura de resultados, será somente a obra realizada, com tudo aquilo que ela tem de específico e intraduzível ${ }^{9}$, a responsável pela oferta aos sentidos. Parece não ser tão incomum entre arquitetos, inclusive, a idéia de que a arquitetura não prescinde de materialização para que seja entendida e pensada como tal (cosa mentale). Embora esse senso deva ser visto com algumas reservas - pois pode levar à idéia de dispensa de formalização nos raciocínios operados antes de se atingir a "representação" final da obra -, chamamos a atenção para ele, pois coloca em evidência os cálculos do processo de interpretação de que depende a arquitetura. É bastante significativo que grande parte do que chamamos de produção arquitetônica (talvez a maior parte)

8. Abrindo uma entrevista a Eva Meyer, Jacques Derrida disse: "Consideremos o pensamento arquitetônico. a o problema da arquitetura como uma possibilidade do próprio pensamente, que não pode ser reduzida categoria de representação do pensamento. / Como você aludiu a uma separação entre teoria e prática, podemos começar nos perguntando como aconteceu essa divisao de trabalho. Penso que, no momento em que distinguimos a theoria da praxis, percebemos a arquitetura como uma mera técnica, descolada do pensamento. Quem sabe, não haverá, talvez, um caminho de pensamento, ainda por descobrir, que faç "Entrevista de Jacques Derrida a Eva Meyer. Uma arquitetura onde o desejo pode morar" In. NESBITT, Kate. Uma nova agenda para a arquitetura: antologia teórica (1962-1995). São Paulo, Cosac Naify, 2006, p.166 
não seja feita de pedras, aço e cimento aglomerados em luta contra a gravidade, mas de grafite e nanquim depositados sobre o papel, formando desenhos e palavras. Também é notável que muitas das contribuiç̃es mais importantes para o pensamento da disciplina não tenham sido concretizadas, como as etapas intermediárias de alguns projetos que posteriormente sofreram interferências de maior força ou as pranchas finais de outros que não puderam ter sequência. Da mesma forma, os diversos experimentos que não poderiam (ou não queriam) ser concretizados pelas mais diversas razões, sejam elas políticas, sociais e até mesmo físicas, mas que apresentaram novas possibilidades para a arquitetura e se incorporaram no pensamen to coletivo sobre ela: os edifícios monumentais de Étienne-Louis Boullée, as explorações dos artistas-arquitetos soviéticos Iakov Chernikhov, Kazimir Malevich, Ivan Leonidov e Vladimir Tatlin, as contra-construções de Theo van Doesburg, a produção crítica e política do Superstudio e Archigram, além de uma infinidade de outras manifestações arquitetônicas ${ }^{10}$.

9. "O filósofo (...) não faz muita idéia da importância dos modos materiais, dos meios e dos valores de execuçāo, porque tende invencivelmente a distsingui-los da ideia. Repugna-he pensar numa troca 'fundo', entre a conscî̀ncia e auco que elejulga acidente co que julga substancia, entre a forma' eo generalizado, a liberdade adquirida comon essas trocas, a existência no artista de um tipo de medidd comum escondida entre elementos de natureza extremamente diferente, éa colaboração inevitável e indivisivel, a coordenacão, a cada instante e em cada um de seus atos, do arbitrário e do necessário, do esperado e do inesperado, de seu corpo, de seus materiais, de suas vontades, e de suas ausências mesmo, que permitem enfim associar à natureza considerada como fonte praticamente infinita de assuntos, de modelos, de meios e de pretextos algum objetto que náo pode ser simplificado e reduzido a um pensamento simples e abstrato, porque tem a sua origem e o seu efeito num sistema intrincado uma tese é reter-lhe o essencial. Resumir (ou substituir por um esquema) uma obra de arte é perderhe o essencial. Vê-se o quanto essa circunstância (se se compreender o seu alcance) torna ilusória a análise do esteta". VALÉRY, Paul. "Leonardo e os Filósofos". In: Introdução ao método de Leonardo da Vinci. São Paulo, Editora 34, 1998, p.201.

10. Poderiam ser somados à lista, diversos outros textos nãa arquitetônicos, sejam eles verbais - os os das artes plásticas, do design, da música e do cinema - - que reverberaram de maneira bastante incisiva no pensamento sobre a disciplina.
Nesse sentido, buscando se afastar da visão pálida e cristalizadora de algumas análises - se comparadas com a riqueza que uma obra pode oferecer como comunicação - e procurando reunir as ferramentas que possibilitem leituras das obras de arquitetura como parte de um processo em pleno movimento, coloca-se a necessidade de atenção, além da própria obra realizada e incorporada na vida cotidiana e da produção da crítica e da historia que se refere a ela, aos diversos registros do processo de projeto e aos procedimentos desenvolvidos ao longo da sua construção, entendidos aqui como elementos que fizeram parte do pensamento sobre aquela obra. Melhor dizendo, coloca-se a necessidade de leituras da obra de arquitetura que considerem e estejam atentas aos raciocínios operados na sua configuração formal e às relações que a estruturam como linguagem. Dizer que há a necessidade de se desenvolver leituras desse tipo, significa dizer que há a necessidade de que essas leituras contemplem - como uma das partes do conjunto de relações que nelas se constroem, e que as constituem como hipóteses - alguns dos elementos emergidos na semiose do projeto.

Alterando de maneira significativa os rumos desta pesquisa, o conceito de diagrama e de raciocínio diagramático de Peirce, cujo estudo se tornou o elo entre os diversos trabalhos do Grupo de Pesquisa Semiótica da Comunicação, do qual participo desde o ano de 2012, transformou a maneira como a obra e o projeto de arquitetura estavam sendo pensados. Mesmo não sendo assumido como o objeto principal da investigação - já que a pesquisa se propõe o estudo de uma ocorrência 
cultural e não da ontologia do diagrama, por exemplo -, ele se faz presente como um elemento que atravessa horizontalmente todas a explorações realizadas. Como pesquisa cujo objetivo inicial era o de empreender uma investigação sobre a linguagem da arquitetura e sobre a representação nos processos que antecedem a realização da obra, ou seja, o projeto e a construção, ganhando posteriormente mais concretude com a análise de uma obra, o trabalho sentiu o forte impacto do contato com o conceito de diagrama em diversos níveis, desde as preocupações com o modo de análise, até a forma como a dissertação se estruturou, fortemente baseada na exploração da visualidade e do cruzamento de leituras de diversas naturezas.

Diante das dificuldades encontradas na formulação e no andamento da pesquisa e temendo o risco de se perder no labirinto de espelhos (e no acompanhamento dos reflexos de si mesmo) que o verbal tende a construir, fui em busca de uma realização que servisse de lugar onde as questões que emergissem pudessem ser trabalhadas. Assim, foi colocada como necessidade a escolha de uma situação exemplar, de uma obra de arquitetura onde pudessem ser flagrados com maior clareza, dada a saturação dos códigos, os indícios que me levassem (como mera possibilidade) aos caminhos percorridos nos processos de projeto e construção, e desses de volta à interpretação da obra. Nesse cenário surgiu a figura de Peter Eisenman, arquiteto norte americano cuja trajetória peculiar marcou profundamente o debate arquitetônico, sobretudo a partir do final da década de 1970. Embora o objeto de investigação procurado fosse uma obra e não o percurso de um arquiteto, no caso de Eisenman um recorte frio se tornaria não somente complicado, como impossivel de ser feito, pois, se as suas construções podem ser analisadas de forma isolada, podem também ser entendidas - e de maneira bastante clara - como momentos de uma sequência investigativa. Os vínculos e associações entre cada obra, entretanto, não se dão apenas por contiguidade e a partir de um elemento em comum que não diz respeito diretamente à forma das obras: o arquiteto Peter Eisenman. Suas ligações se dão em diversos níveis e são declaradas publicamente em diversas formas. Se, como diria Pignatari, toda obra de arquitetura é crítica das obras que a precederam, nos trabalhos de Eisenman essa relação se coloca de maneira bastante contundente e visivel. Impõe-se à análise de qualquer obra do arquiteto um voo panorâmico por todo o território do qual ela faz parte, necessidade reforçada pela fertilidade da sua dupla produção: a projetual e a teórica.

A atividade de Peter Eisenman no projeto se confunde com a sua atividade na teoria. A produção dos inúmeros textos, que são vistos como correspondentes argumentativos de seus projetos, mas que possuem um grau muito grande de independência, constitui uma investigação teórica que demonstra de maneira declarada o caráter exploratório da sua obra. A aproximação com as artes plásticas e o interesse pela filosofia de Derrida (com quem chegou a dividir em 1987 a autoria de um projeto no Parc de la Villette em Paris) poderia submeter a arquitetura a outras formas de pensamento que a levariam ao limite de sua dissolução, deixando de ser uma para ser pensada como a outra. 0 que se constata, no entanto, já que seus projetos e suas obras desenvolvem formulações não-verbais em diálogo (e não submissão) com as questões desenvolvidas na teoria, é a tentativa de redefinicão da disciplina e de tensionamento da linguagem. Desenhando textos e escrevendo arquiteturas, Eisenman tenta construir uma trilha que, com algum esforço, poderia ser seguida por aquele que quisesse acompanhá-lo.

Aquilo que o arquiteto desenvolve como questão central no campo da teoria, ou seja, a investigação sobre a linguagem da arquitetura e sobre o própria atividade projetual, é desenvolvido de maneira paralela em algumas de suas obras, deixando na configuração final da obra índices das hipotéticas operações efetuadas durante o processo, pegadas que apontariam para possíveis caminhos, percurso esse que seria o próprio ato de interpretação da obra e que poderia ser entendido como comunicação arquitetônica. Deixando, em certa medida, ser levada 
pelo encadeamento de proposições, ao mesmo tempo em que seguia as pegadas deixadas pelo caminho desenhado, esta pesquisa lançou un olhar sobre a produção arquitetônica de Peter Eisenman (suas obras e seus textos) buscando centrar-se na análise de uma obra específica, o Memorial dos Judeus Assassinados da Europa (também conhecido como Memorial do Holocausto), construído em Berlim.

A peculiaridade dessa obra e seu caráter exemplar para o tipo de exploração que eu havia escolhido fazer foi o motivo de sua escolha, entre tantas outras possibilidades, como objeto para a minha análise. A primeira particularidade morava no fato de que a obra era resultado de uma parceria entre Eisenman e o escultor americano Richard Serra, parceria que, entretanto, limitou-se apenas à primeira fase de projeto, já que o artista abandonou a empreitada após algumas dificuldades encontradas na relação com o governo alemão. Esse fato poderia provocar no meu trabalho, assim como ocorre em outras importantes pesquisas recentes, uma discussão a respeito da relação entre arte e arquitetura, ou ainda sobre o sentido que a dissolução das suas fronteiras ganha na reflexão sobre o mundo contemporâneo. Minha proposta de trabalho, entretanto, era a de empreender o exercício de análise de uma ocorrência cultural específica, e uma obra que transitava livremente entre as fronteiras dos antigos campos e que, às vezes, pelo suposto hibridismo, inviabilizava o uso de certas ferramentas oferecidas pela teoria ou pela história da arquitetura parecia ofertar muitas possibilidades de interpretação.

Outra característica - a essa última relacionada - dizia respeito à ideia de função e ao programa, elementos tão caros à arquitetura moderna. 0 programa e o problema central da obra a ser resolvido, a questão a ser equacionada, ou seja, a representação do massacre de 6 milhões de judeus e de toda a complexidade da memória do Holocausto, possuiam um grau de vagueza tão grande como o próprio sentido da palavra que dá origem ao programa, ou seja, a memória. Arquiteturalmente (ou artisticamente), a exploração desse "problema" é especialmente interessante e fértil pela sua complexidade. Assim como observou Eisenman certa vez em relação aos museus, o programa memorial "oferece muito pouco no sentido de necessidades funcionais específicas que podem atuar tanto como uma sugestão ou limitação para um desenvolvimento formal" ${ }^{\prime 1}$. Ao mesmo tempo, a questão, que também se relaciona diretamente com a discussão em torno da ideia de monumento, foi amplamente debatida no período de gestação da iniciativa e permaneceu viva graças às diversas polêmicas em que a obra foi envolvida ao longo dos anos que sucederam a escolha do projeto de Eisenman até a inauguração no ano de 2005. Um complicado processo que ao todo durou aproximadamente dezesseis anos e que me deu a possibilidade de contato com o vasto material relativo a esse período, composto por críticas especializadas e ensaios teóricos, notícias em jornais e revistas, etc.

Entre os dias 17 e 25 de julho de 2012 estive pela primeira vez em Berlim. Durante esse curto espaço de tempo, imergi em uma espécie de rotina, me dedicando quase que exclusivamente a uma única atividade diária: visitar o Memorial dos Judeus Assassinados da Europa. Nessa quase-profıssão temporária - marcada , inclusive, por aborrecidos e repetitivos procedimentos - produzi uma série 
de registros que participaram de um processo de transformação no meu pensamento a respeito daquela obra em Berlim. Uma enorme distância foi percorrida entre a visão que eu tinha do Memorial - da qual faziam parte os textos e fotografias em livros e revistas, os filmes, vídeos, mapas eletrônicos, etc. - e aquela com a qual voltei, resultado da transformação provocada pela experiência da obra da qual passou também a fazer parte, de maneira extremamente forte, a própria cidade de Berlim.

Mesmo não podendo reconstruir ou recontar esse processo, trazer alguns pontos de contato com o texto de uma dissertação de mestrado se tornou algo desejado e perseguido. Sendo assim, o texto construído aqui é uma reunião de instantâneos de percurso, de impressões recuperadas, de fragmentos de uma narrativa imaginada e interpretada pelo verbal. Tentando construir uma análise da obra que contemplasse de alguma maneira a dimensão daquela experiência - já que, além de tudo, para mim qualquer fria separação havia se tornado não somente inaceitável, como impossivel de ser concebida - promovi o cruzamento dos instantâneos de percurso - escritos, não à toa, em primeira pessoa - com comentários e análises escritas em outros momentos ${ }^{12}$, com reflexões feitas partir de achados de pesquisa, sobretudo o material encontrado no acervo de Eisenman no Canadian Centre for Architecture ${ }^{13}$, com recortes de textos e imagens, algumas das mais de cinco mil fotografias feitas em Berlim e, finalmente, com desenhos analíticos feitos durante a viagem e agora na finalização do trabalho. Assim, o conjunto de três capitulos procura desenhar um percurso análogo

12. Alguns trechos de três textos publicados durante o mestrado foram, ao longo da dissertaçăa - incluindo a introdução -, retrabalhados e recombinados em um novo texto. São eles: "Espaço diagrama". In: Arq.Urb, n.7, 2012, p. 17-32; "Sobre o Memorial dos Judeus Assassinados da Europa". In: Anais do 20 Seminário Internacional Representar Brasil 2013. As representaçoes na Arquitetura.

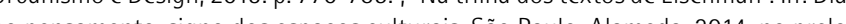

ao desenvolvido ao longo da pesquisa, do qual fizeram parte não apenas as atividades normais de leitura e escrita, como também a experiência em Berlim, a vivência da obra e o tempo de toda a reflexão. Procurando permanecer atento ao suporte texto/imagem de uma dissertação, condensei o processo de três anos no relato ficcional de uma jornada de um dia, limitação temporal que, por sua vez, é análoga à limitação do tempo da pesquisa e indica o caráter parcial e provisório de uma construção desse tipo.

Ainda sem um lugar no espaço (mas não fora do meu mapa) o percurso é iniciado no contato com a obra de Peter Eisenman, procurando reconhecer nos diversos textos e projetos uma forma de pensamento sobre a arquitetura e os elementos que poderiam me ajudar na interpretação do Memorial. Assim, o primeiro capítulo se construiu como uma espécie de panorâmica cronológica da obra de Eisenman que, no entanto, não conta a sua história, mas a minha,

13. A consulta ao arquivo do Canadian Centre for Architecture, que oficialmente abriga o acervo de Peter ilsenman, foi desde os primeiros meses da pesquisa, assumido como fundamental no embasamento da prelimitar boa parte do conteúdo do arquivo. Entretanto a maior parcela do acervo de Eisenman ainda encontra-se guardada em outro edifício, um arquivo off-site, esperando a catalogação detalhada e digitalização. Após algumas correspondências com a direção do centro, foi dada a autorização para a consulta desse arquivo off-site, consulta que, diante da impossibilidade de ser feita pessoalmente - por problemas de agenda e pela falta de recursos -, foi realizada pela arquiteta Georgia Lobo no dia 14 de setembro de 2012. Foram levant lados $\mathrm{e}$ fotografados desenhos de estudo, diagramas conceituais pranchas do projeto executivo de arquitetura, anotaçoes sollas, recortes eopias de livos anotados, contato até aquila a base de um panorama das 4 versões por que passou o projeto do Memorial dos Judeus Assassinados da Europa. Não foi disponibilizado pelo centro canadense o acesso a uma importante parcela do material relativo ao projeto: os dezoito CD's cujo conteúdo não foi nem ao menos informado eos quinze modelos fisicos que constam na listagem textual online do acervo. Muito provavelmente, os CD's contêm arquivos eletrônicos que poderiam me dar novas bases para uma reflexāo a respeito do projeto e da construção, o que certamente mudaria os rumos desta pesquisa e do seu resultado da obra considero ter sido fundamental, sobretudo na primeira fase de projeto. Assim, penso que um nova pesquisa sobre o Memorial dos Judeus Assassinados da Europa (ou a continuação desta) deveria obrigatoriamente ser iniciada pela tentativa de acesso à totalidade do material no acervo do CCA. 
seguindo a trilha deixada pelo arquiteto. A jornada ganha tempo e espaço na sequencia que narra a chegada à cidade de Berlim e o percurso entre o lugar onde me hospedei e o Memorial. 0 fato de 0 confronto com Berlim ocupar um capítulo inteiro da dissertação é bastante significativo se tivermos em vista que inicialmente uma reflexão sobre a cidade não havia sido prevista, a não ser para a tentativa de compreensão da forma do lote e do entorno imediato do Memorial. 0 espaço que Berlim ocupa neste texto é proporciona ao peso que exerceu sobre a minha interpretação da obra. Com a chegada ao Memorial dos Judeus Assassinados da Europa, narrada no terceiro capítulo, o desenho que o meu deslocamento faz no mapa da narrativa perde novamente os vínculos diretos com a cartografia. Se antes desenhava uma linha clara e reconhecível através da qual era possível deduzir aquilo que havia entre um ponto e outro (uma esquina, uma construção, uma avenida), no mergulho e deriva pelos elementos indistinguiveis organizados no grid da obra de Eisenman, a descrição do meu deslocamento feita na forma de desenho perde seu sentido de utilidade (o que não significa uma perda de interesse). Assim, a visita à obra não é descrita através do desenho de um deslocamento no território, mas no tempo: o mergulho e a deriva.

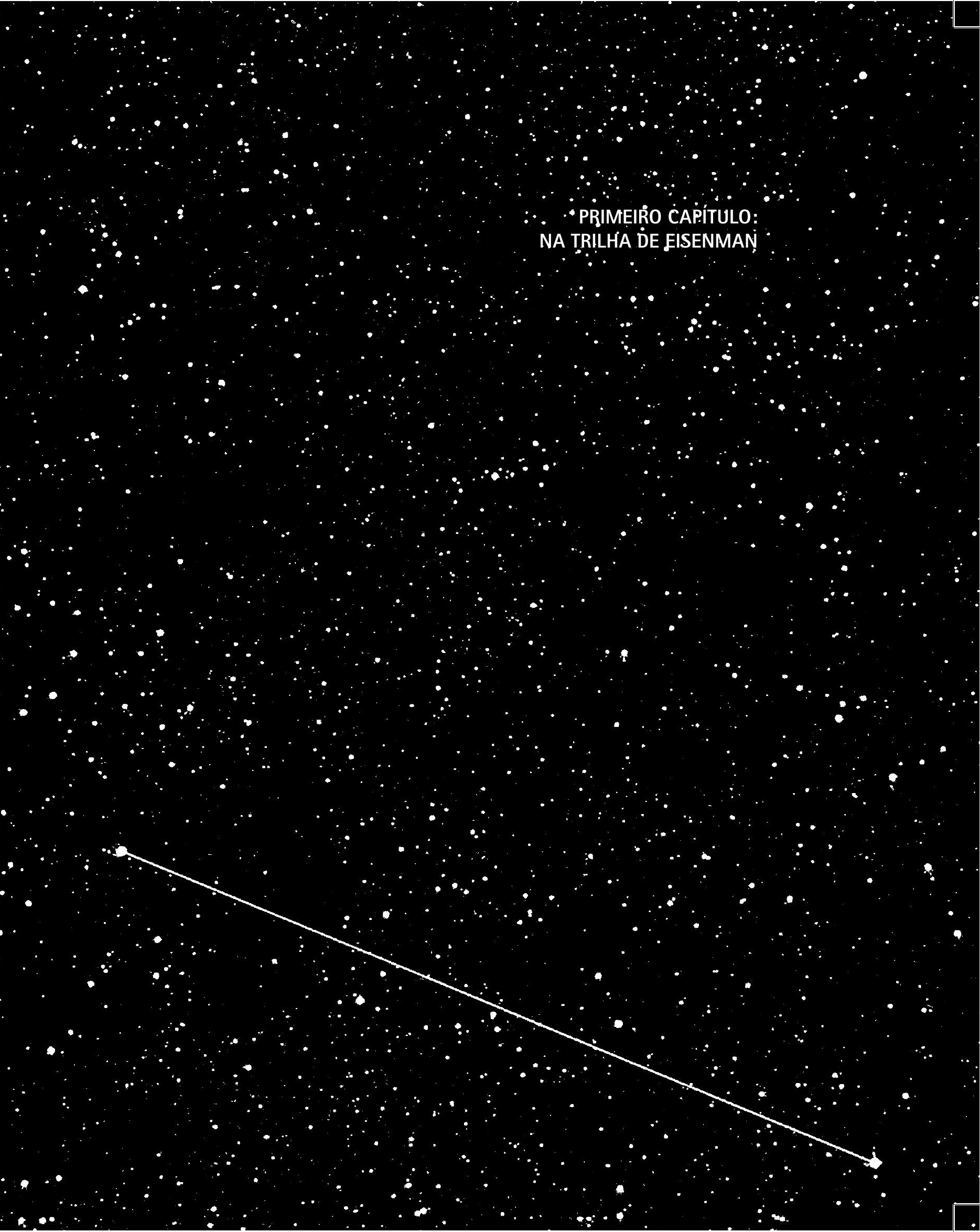




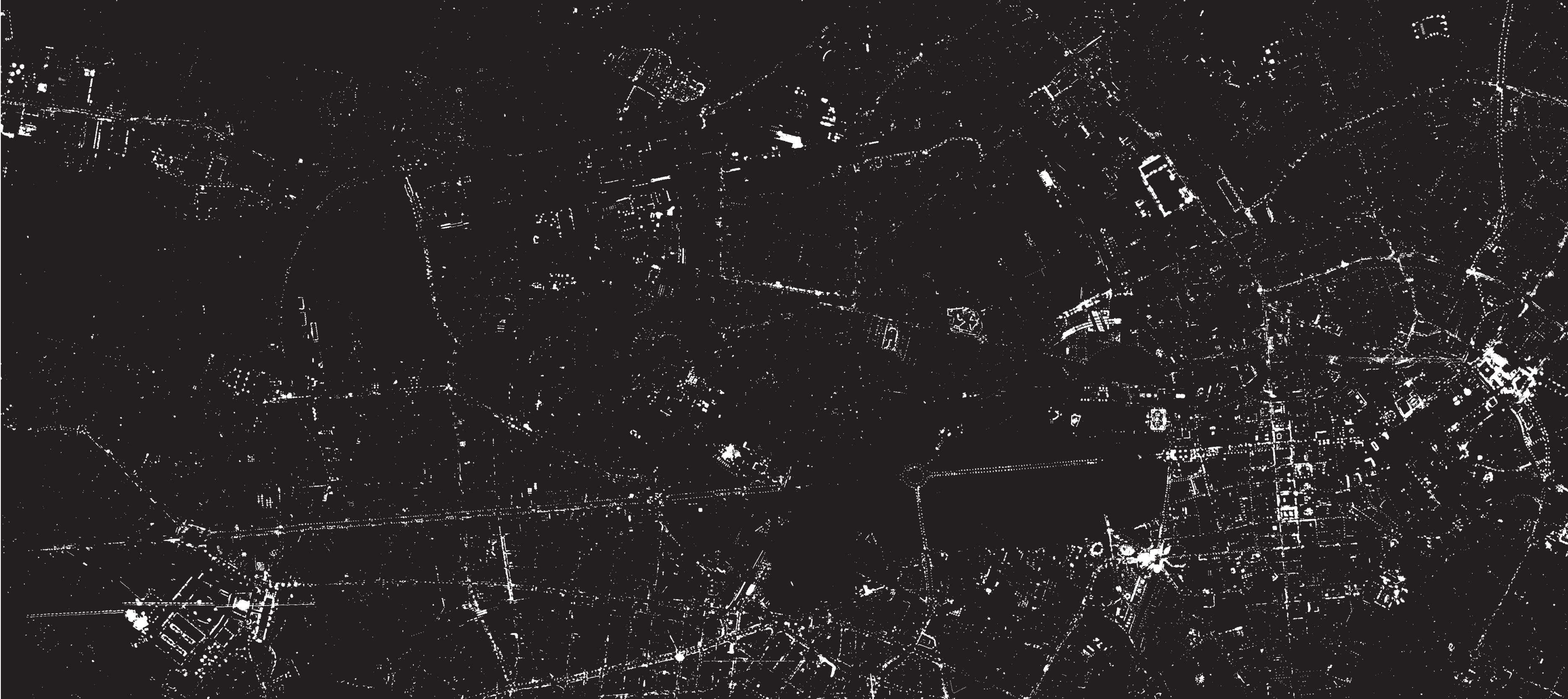

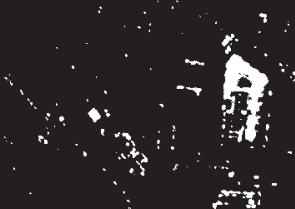

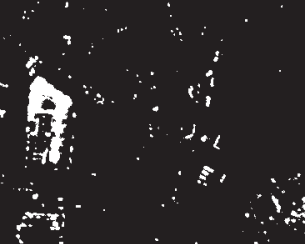

$+4$ 
0. Navegar é desenhar uma linha sem régua ou esquadro. Caminha-se para frente em sucessivas e intermináveis correções de rota, mirando um impreciso ponto, quase sempre invisível aos nossos olhos, guiando-se por inconstantes e variáveis referências: os ventos e correntes marítimas, a misteriosa dinâmica de campos magnéticos na superfície da Terra, a posição de estrelas e planetas, as fases da lua descritas em uma espécie de adivinhação feita a partir da consciência de um eterno e constante movimento. E ainda, sem o conhecimento daquilo que compõe a própria caminhada, ou seja, os lugares por que se passa e os momentos que são vividos. Sobre o traçado rigoroso e calculado da cartografia - que, apesar da aparente precisão, se realiza apenas como uma convenção, um acordo entre partes, como o produto de uma negociação entre o espaço e a capacidade de percepção, compreensão síntese das operações feitas pelo cartógrafo - desenha-se um plano que, a cada passo dado, a cada milha percorrida, tem sua estratégia reformulada, concretizando-se em uma linha cuja sinuosidade conta algo a respeito do embate entre aquele que se desloca e os lugares e momentos por onde passa. A linha torta e imperfeita não se desenha seguindo apenas seus próprios desígnios, mas também as condições que a cada momento lhe são dadas. 
Mas, como projeto (e com os olhos cravados no destino, que define o seu rumo), imagina-se linha reta, a menor distância entre dois pontos (ou ao menos, a menor possível), caminho certo e coerente. E, sobretudo após ser alcançado o objetivo e ao construir-se como narrativa, mostra-se como um percurso no qual até mesmo os percalços parecem ser parte de uma sequência de acontecimentos perfeitamente ajustados e combinados, um encadeamento que não poderia preceder algo que não fosse o motivo do deslocamento, o ponto de destino. Elementos isolados, eventos aleatórios, todas as suas partes desconexas são forçosamente arranjados na diacronicidade da linha narrativa. Nessa odisseia, todos os obstáculos, acidentes e desvios de rota ganham certo sentido ou utilidade. Destino e percurso assim se fundem, passando a fazer parte da mesma descoberta, um movimento que não anula a especificidade de cada ponto vivido (no espaço e no tempo) - já que suas qualidades só poderiam mesmo existir como instante na consciência de quem os viveu -, mas que, pelo contrário, cria uma possibilidade de contato entre aquele que se detém à narrativa e o oceano de elementos que a sustentam como construção.
Recompor meu percurso até aqui, dispondo no plano ou na linha tudo aquilo com que me deparei ao longo desses três anos, é um exercício de linguagem, um esforço de tradução que, como tal, envolve seleção, interpretação e transformação das qualidades de um a partir das qualidades de outro. Elementos soltos no tempo, lugares vividos e imaginados, recortes de jornal, entrevistas e vídeos, ruinas em fotografias e mapas antigos, cemitérios, textos de Eisenman e obras de Serra, todos os momentos vividos na viagem a Berlim condensados no encadeamento de palavras e imagens que compõe essa dissertação de mestrado, realização que me coloca o compromisso com uma linearidade e inteligibilidade que não é necessariamente própria da atividade de pesquisa e, muito menos, da maneira como desenvolvi um pensamento a respeito da obra de Eisenman. Mas seria inútil debater-se contra esse compromisso (que voluntariamente abracei três anos atrás) e contra uma incômoda impossibilidade colocada de antemão, a de não poder trazer para esse meio tudo aquilo que percebo como fundamental na experiência, tudo aquilo que faz parte do meu entendimento sobre aquela obra e sobre aquela cidade. Ao invés disso, e sem o risco de ser pego de surpresa por tantas limitações e impossibilidades, me sento agora à margem da experiência para transformar a deriva em odisseia, espaço em plano, ponto em linha, encarando a tarefa como atividade criativa, como trabalho de tradução. Ao invés de tentar figurar em recortes e descrições a aparência do objeto, buscando a sua explicação ou o seu resumo, recrio em palavras e imagens, submetidas às suas próprias limitações e às daquele que as trabalha, o movimento de uma descoberta, traduzido aqui como a narração de um percurso de investigação. 
Toda jornada tem um ponto de partida e todo desenho, que se define a partir do reconhecimento de uma ação, de um gesto cuja história é contada pelo rastro que deixou, precisa antes de um primeiro contato entre a ponta do lápis e um ponto na superfície do papel. Diante de um mar de possibilidades, escolhe-se uma específica a partir do qual a mão, antes livre da ideia de história, começa a registrar um gesto: não qualquer gesto, mas aquele específico que vai se fazendo em interação com os olhos e com a consciência da sua existência no tempo. A escolha do ponto define o começo do desenho, influindo assim nos seus resultados: trata-se de uma escolha absolutamente arbitrária que, se não determina, ao menos interfere na defınição de um caminho. Dessa maneira, começo aqui o registro do processo de pesquisa sobre o Memorial dos Judeus Assassinados da Europa recuperando o contato feito com a produção de Eisenman, muito embora meu trabalho não tenha partido da investigação de um arquiteto ou de uma construção em específico.

Embora arbitrária, não se trata de uma escolha aleatória. 0 percurso iniciado na seleção do mestrado teve seu rumo - o projeto de percurso ou desejo de um específico desenho final - profundamente alterado no momento em que, após o contato com as publicações, optei por vincular a discussão da ideia de representação na arquitetura, objetivo que eu perseguia desde o final da graduação, à análise de uma ocorrência cultural, neste caso, uma obra construída de arquitetura Mesmo sendo parte do mesmo processo, a decisão significou uma ruptura, uma interrupção no traçado que começava a ser feito: 
2. Ainda em terra e sem rumo, vagando perdido no labirinto,

lembro-me do diagrama que Teseu desenhou com o fio de 1. VALÉRY, Paul. Introdução ao

Ariadne e começo a traçar a minha estratégia de caça e $\quad$ método de Leonardo da Vinci

fuga. Viro em um corredor, subo e desço rampas, atravesso

o grande salão, vasculho caminhos e li- $\quad$ 2. "(...) o labirinto do continuo não é uma

gações recolhendo os fragmentos que linha que se disso/veria em pontosindepen-

encontro, pistes, como a areia fluida dissolve-se em

grãos, mas é como um tecido ou folha de pa-

arquiteto. Não me basta pel que se divide em dobras até o infinito ou

apenas encontrá-lo: será preciso com- que se decompóe ém movimentos curvos (...)

preender o caminho traçado para poder labirinto é a dobra, nỗo o ponto, que tunca

voltar ao ponto de origem e encontrar a é uma parte, mas uma simples extremidade

da linha". DELEUZE, Gilles. A dobra: Leibniz

e o Barroco. Campinas, Papirus, 1991, p.17.

3. "Enquanto a semelhança não
pode prescindir da comparação

une a de outra A ponta de uma linha se

une a de outra e, apesar da precariedade a relação de similaridade não se

dessa união, dos fios que permanecem $\quad \begin{aligned} & \text { orienta pela comparação, mas pela } \\ & \text { transformaç̃o de qualidades com }\end{aligned}$

soltos ou que pendem como as rabiolas base num processo que se manifes-

das pipas nos postes de rua, reconheço ta como interpretacão, semiose ou

o emaranhado como conjunto. A cada simplesmente gesto. Assim, pode-

passo dado, reúno os pequenos pedaços mos indagar: entre os traços que

desenham o mapa e o território a

relacão de similaridade? Seģundo

todas as evidências, os mapas de-

$\begin{array}{ll}\text { à outra extremidade do caminho que } & \text { senham o território a partir de rela- } \\ \text { vejo agos de similaridade sem, contudo, } & \text { çsendo insinuado. }\end{array}$

Talvez fosse mais correto, tendo em vista o objetivo do $\begin{aligned} & \text { estabelecer semelhanças. A compo- } \\ & \text { sição de mapas explicita apenas e }\end{aligned}$

desafio que me foi colocado - a compreensão do gesto de tão somente o cálculo dedutivo de

Eisenman -, tecer um fio cuja simplicidade me permitisse toda operação mental baseada ino

um percurso em qualquer sentido, que pudesse ser re- MACHADO, Irene. "Diagrama como

colhido e novamente estendido mantendo-se aquilo que problema semiótico". In: Diagramas:

nele importa, ou seja, ter as suas partes, o começo meio dos espaços culturais. São Paulo,

e fim, facilmente distinguiveis e o seu corpo, o conjunto, Alameda, 2014, no prelo.

coeso e preservado: uma ponta certamente me levando à outra.

Mas no meio caminho encontro novamente Paul Valéry - a

figura que me persegue e que, ao mesmo tempo, persigo desde

o começo da jornada - desenhando seu personagem fictício,

Leonardo da Vinci, o filósofo não-verbal. Comentando seu

próprio desenho, me diz:

"Um autor que compõe uma biografia pode tentar viver seu personagem, ou, então, construí-lo. E há oposição entre essas duas resoluções. Viver é transformar-se dentro da incompletude. A vida nesse sentido é toda anedotas, detalhes, instantes. A construção, ao contrário, implica condições a priori de uma existência que poderia ser - totalmente diferente. Essa espécie de lógica é o que leva na sequência das experiências sensiveis a formar o que denominei (...) Universo e conduz aqui a um personagem. Trata-se, em suma, de um uso do possivel do pensamento, controlado pelo máximo de consciência possivel"'.

4. Obrigação da qual o próprio
Eisenman se exime diante da tarefa

de narrar a si mesmo em um dos seus textos: "Escrever este texto narrativo sobre o processo de diaToma um processo que não tem uma trajetória interna e força-o a obedecer a uma estrutura narrativa". EISENMAN, Peter. Diagram Diaries. London, Thames \& Hud

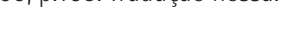

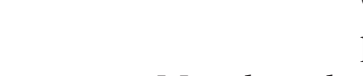

pre frágil), cujas junções opto por
aparentes. Meu desenho se faz de pontos, linhas e palavras, conjunto de fragmentos que não reconstitui o percurso ou gesto de Eisenman, mas que constrói um lugar (ou caminho paralelo) através do qual o interpreto: desenho aqui não o arquiteto, mas o mapa ${ }^{3}$ que me guia na jornada até a sua obra. Assim, livre da obrigação de capturar Eisenman ${ }^{4}$ mas ainda determinado a persegui-lo até Berlim, continuo andando pelos corredores do labirinto, acompanho as pistas deixadas pelo caminho e recolhendo-as no meu desenho

de linhas soltas.
As linhas que reúno para formar esse rastro distinguem-se do

E, por mais que possam parecer perfeitas e sem emendas, em um exame mais atento se infinidades de dobras, emaranhaos de outros fios². Experiência é estalo no empo que escorre entre os dedos e escapa aos olhos. Este texto é construção, realizacão que se faz pela criação de equilíbrio no mpilhar de pedras e conceitos (obra sempor deixar 
The Formal Basis of Modern Architecture. Tese de doutorado em Filosofia defendida em agosto de 1963 na Universidade de Cambridge. Não a primeira pegada que encontrei, mas, na verdade, uma das últimas. Induzindo uma estratégia de navegação e tentando construir um fio narrativo, abro com ela, entretanto, meu desenho que quer ser mapa.

Vejo aqui o jovem arquiteto americano após uma longa viagem pelo Velho Mundo, iniciando a tarefa que ocupou toda a sua vida: a exploração da linguagem da arquitetura em suas entranhas, em seus movimentos internos, tentando, a partir dessa "interioridade", definir a sua autonomia como disciplina. Mais à frente, o velho Eisenman dirá ao olhar para seus papeis reunidos: "Minhas ideias a respeito dessa 'interioridade' tiveram muitos nomes diferentes ao longo dos anos - estrutura profunda, imanência, base formal, entre eles"6. E, em um ponto intermediário, ao ser aproximado da figura do filósofo alemão que descreveu a si mesmo como sendo um arquiteto:

De fato eu possuo certa afinidade com Wittgenstein, porém, enquanto Wittgenstein se considerava como um filósofo-arquite to, eu realmente não quero me considerar um arquiteto-filósofo, porque eu não gostaria de considerar estas categorias ou definições servindo de suporte uma à outra. A arquitetura é tradicionalmente proveniente desta noção que a toma como uma disciplina secundária, mas, ao se mergulhar na arquitetura, encontra-se filosofia. O que eu gostaria de considerar é que ao se mergulhar profundamente na filosofia, pode-se topar com a arquitetura, isto é, que existe uma reversibilidade entre o discurso filosófico e discurso arquitetônico"'.
5. EISENMAN, Peter. The formal basis of modern architecture. Baden

6. ESENMMAN, Peter. Eisenman inside out: selected writings, 1963-1988. 2004. Tradução nossa.

7. MASP. Malhas, escalas, rastros a dobras na obra de Peter Eisenman. São Paulo, MASP, 1993, p.38. 
Mas nesse ponto da caminhada, Eisenman ainda é um jovem arquiteto cujo olhar se formou na vertigem capitalista americana, tendo cruzado o Atlântico em busca de uma erudição que supostamente lhe faltava ${ }^{8}$, enfrentando uma relação com a ideia de história absolutamente diversa daquela que vivia em seu país, terra em que a arte nesse momento se alimenta de fast-food - devorando frenética e indistintamente latas de sopa, celebridades e estantes de supermercado - e onde, alguns poucos anos adiante, Las Vegas e a Strip serão comparados com Roma e a piazza $^{9}$, e o decrépito Hotel Palenque com as ruínas maias ${ }^{10}$. Como estrangeiro, e sem a desenvoltura que seus colegas europeus exibem ao navegar no denso caldo milenar, acompanha por dois anos Colin Rowe, mas dele logo se separa. Ao invés de uma exploração ao longo do rio, Eisenman opta pelo mergulho, uma exploração no sentido transversal cujo objetivo, o de descobrir o seu nível mais profundo, passa a ser insistentemente perseguido. A base que ele busca dará sentido à expressão arquitetônica, a toda arquitetura independentemente da ideia de estilo ou tradição, uma "linguagem que comunicará a natureza da essência formal de qualquer arquitetura” ${ }^{\prime 1}$.

8. Seu colega de quarto na Columbia, o inglês "tinha um bom senso de projeto mas era um "burro' na compreensão da base teórica e ideológica da arquitetura moderna". EISENMAN, Peter. The formal basis of modern architecture. Baden, L. Muller, 2006, p.378. Traduçăo noss

9. VENTURI, Robert; BROWN, Denise Scott. "Uma mercados A\&tP, ou Aprendendo com Las Vegas". In: NESBITT, Kate Uma nova agenda pasa a arquitetura: antologia teórica (1962-1995). São Paulo, Cosac Naify, 2006, p.346.
10. Comparação feita por Robert Smithson em uma conferência na Universidade de Utah em 1972, comentando fotografias de Guilherme Dets em 1969. Ver: WISNIK, cruzados entre arte a arueviro. dialogos porânea. Tese de doutorado. São Paulo, FAUUSP, 2012, p.152.

11. EISENMAN, Peter. The formal basis of 2006, p.19. Tradução nossa

Do nível mais profundo - que, na verdade, ele nunca encontra, mas que, como mera hipótese, apresenta como descoberta - o arquiteto garimpa sólidos platônicos, o cubo e a esfera ${ }^{12}$, cálculos da geometria, mo vimentos. Seguindo o aprendizado com Wittkower ${ }^{13}$ e Rowe ${ }^{14}$, constrói suas ferramentas e, através delas, passa a olhar e medir todas as realizações arquitetônicas. Como exercício, mas também como demonstração de seu achado, opera a dissecação de realizações da arquitetura moderna: o Pavilhão Suiço e a Cité De Réfuge, de Le Corbusier; as casas Darwin D. Marin e Avery Coonley, de Frank Lloyd Wright; o Centro Cívico e o Museu Tallin, de Alvar Aalto; e, finalmente, o Asilo Infantile e a Casa Del Fascio, de Giuseppe Terragni, que ainda será objeto de novas dissecações em seus textos e projetos.

PETER EISENMAN

2. EISENMAN, Peter The forma basis of modern architecture. Baden, L. Müller, 2006, p.35. Principles in the Age of Humanism. The

(4. ROWE, Colin "The Mathem of the Ideal Villa". In: Architectura
Review, 1947, pp 101-4. 


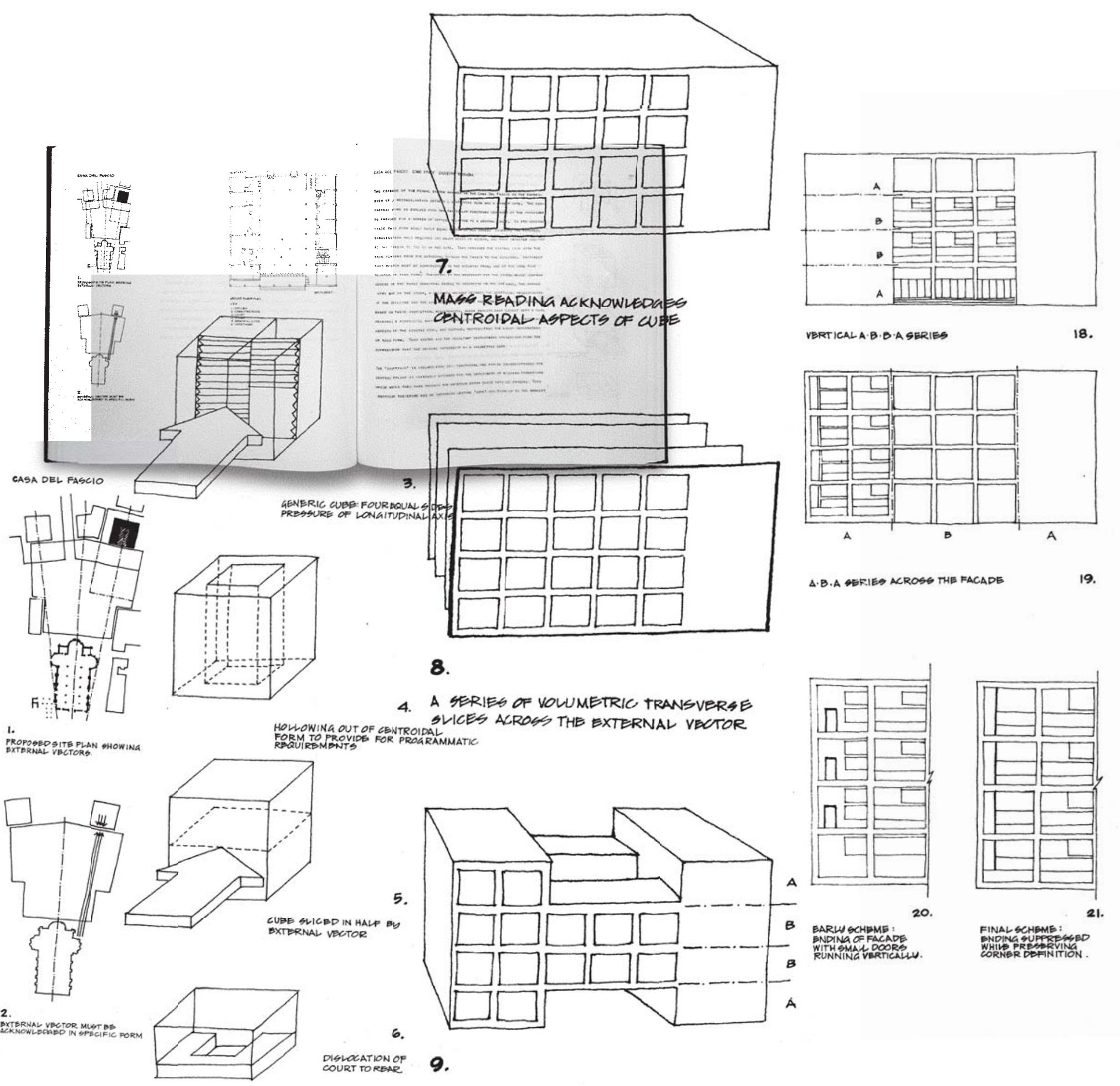

Seu olhar é minucioso, detecta relações entre partes distintas, às vezes até mesmo externas ao edifício, aponta o movimento em paredes e colunas que parecem sólidas e estáticas, eixos longitudinais, transversais, diagonais, progressões, fluxos. E apesar daquilo que possuem de abstração, tais observações só se realizam na materialidade do desenho que o arquiteto constrói, desenho que não apenas demonstra, como também induz e conduz (a partir da sensorialidade) um raciocínio muito particular. Tentando retomar para a Arquitetura o espaço ocupado pela História, Eisenman busca uma teoria própria da disciplina, um aparelho que pense a arquitetura de maneira objetiva - "Essa dissertação (...) se preocupa com questões conceituais, no sentido de que a forma é considerada como um problema de consistência lógica, ou, em outras palavras, como a interação lógica de conceitos formais. 0 argumento tentará estabelecer que considerações de natureza lógica e objetiva podem prover uma base conceitual e formal para qualquer arquitetura"15-, mas, como arquiteto (e não como historiador ou teórico acadêmico) seu método de análise se faz, curiosamente, pelo gesto, pela proposição formal mediada pelo desenho. Os procedimentos de leitura, desenvolvidos nos numerosos desenhos, são repetidos ao longo dos anos e, na volatilidade e imperfeição desse gesto mental e manual, dessa reflexão operada por conceitos e perceptos, se transformam gradualmente em um modo de pensar a arquitetura.

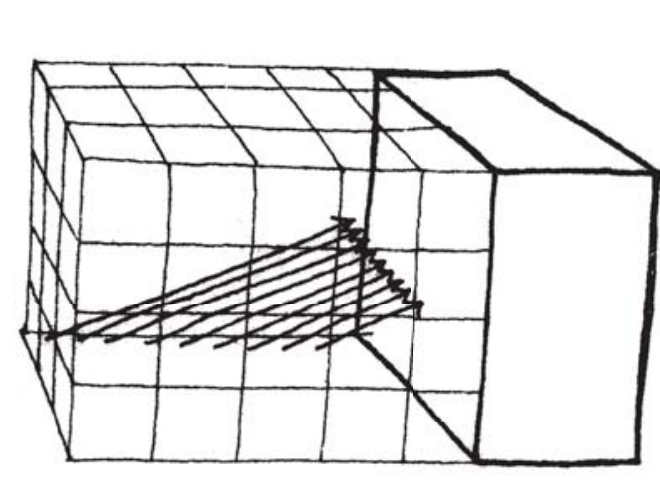

15. EISENMAN, Peter. The formal basis of modern architecture. p.17. Tradução nossa. 
Notes on Conceptual Architecture: Towards a Definition ${ }^{16}$.
16. EISENMAN, Peter. "Notes on Conceptual Architecture: towards a definition". In: Design Quaterly, .78/79, 1970, p.1-5.

17. WISNIK, Guilherme. Dentro do nevoeiro: diálogos cruzados entre arte e arquitetura contemporânea. Tese de doutorado. São Paulo, FAUUSP, 2012.

18. GRAHAM, Dan. "Arte em relação à arquitetura", In: Escritos de artistas: anos 60-70. Rio de Janeiro, Zahar, 2009, p.429-451.

19. WISNIK, Guilherme. Dentro do nevoeiro: diálogos cruzados entre arte e arquitetura contemporânea. Tese de doutorado. São Paulo, FAUUSP, 2012, p.16.

20. Analogia apontada por Stan Allen em: "Trace Elements". In: DAVIDSON, Cynthia. Tracing Eisenman. New York, Rizzoli, 2006, p.58

21. EISENMAN, Peter. "Notes on Conceptual Architecture: Towards a Definition". In: Eisenman inside out: selected writings, 1963-1988. New Haven, Yale University Press, 2004, p.15. Tradução nossa. out: selected writings, 1963-1988. New Haven, Yale University Press, 2004, p.16. Tradução nossa.

23. EISENMAN, Peter. "Notes on Conceptual Architecture: Towards a Definition". In: Eisenman inside out: selected writings, 1963-1988. New Haven, Yale University Press, 2004, p.17. Tradução nossa.

24. EISENMAN, Peter. "Notes on Conceptual Architecture II A". In: EDRA 4: Fourth International EDRA Conference. 1973, p.322. Tradução nossa

25. EISENMAN, Peter. "Notes on Conceptual Architecture: towards a definition". In: Design Quaterly

26. A versão completa analisada aqui foi publicada apenas em 2004 na compilação de escritos do rquiteto: EISENMAN, Peter. Eisenman inside out: selected writings, 1963-1988. New Haven, Yale 


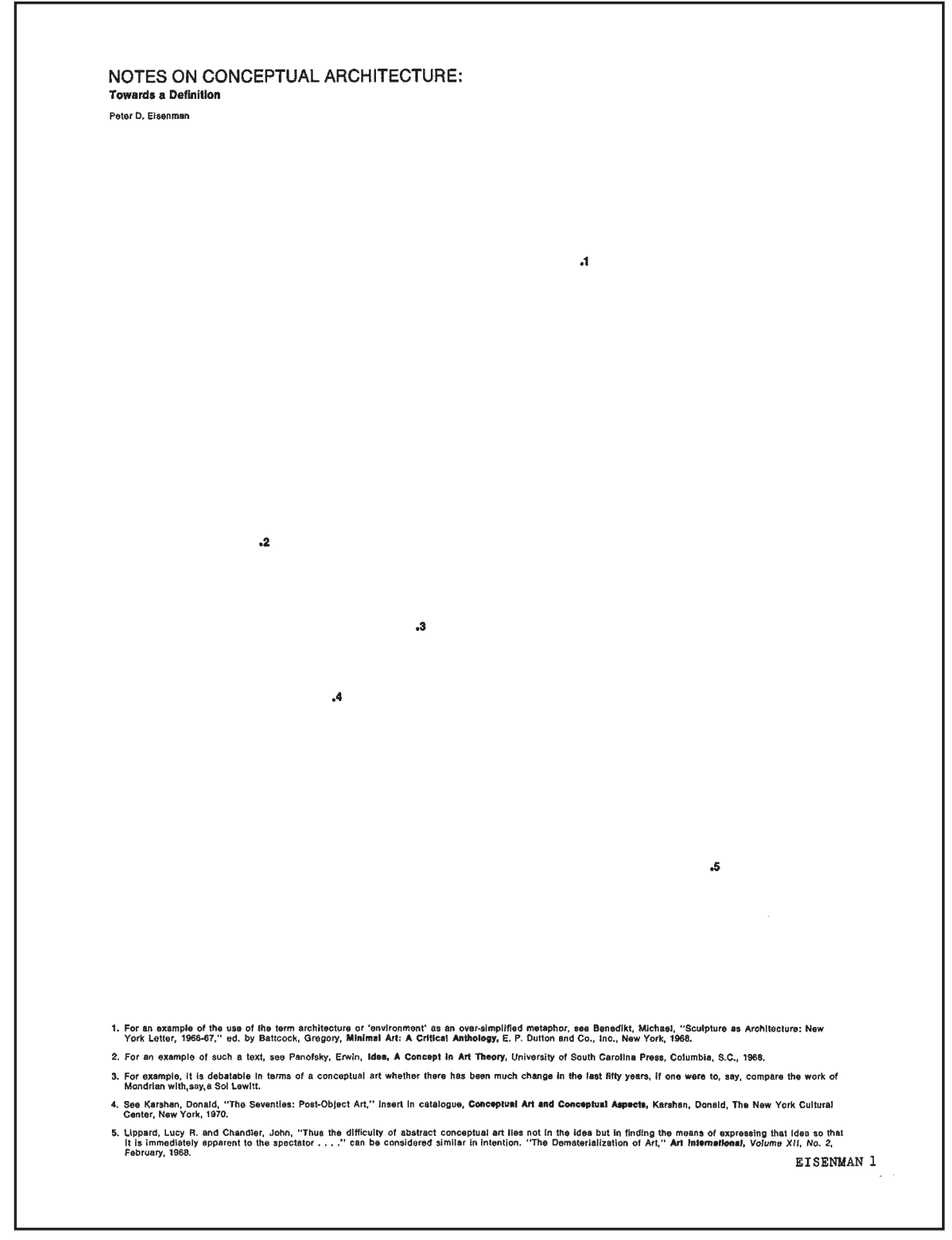

46

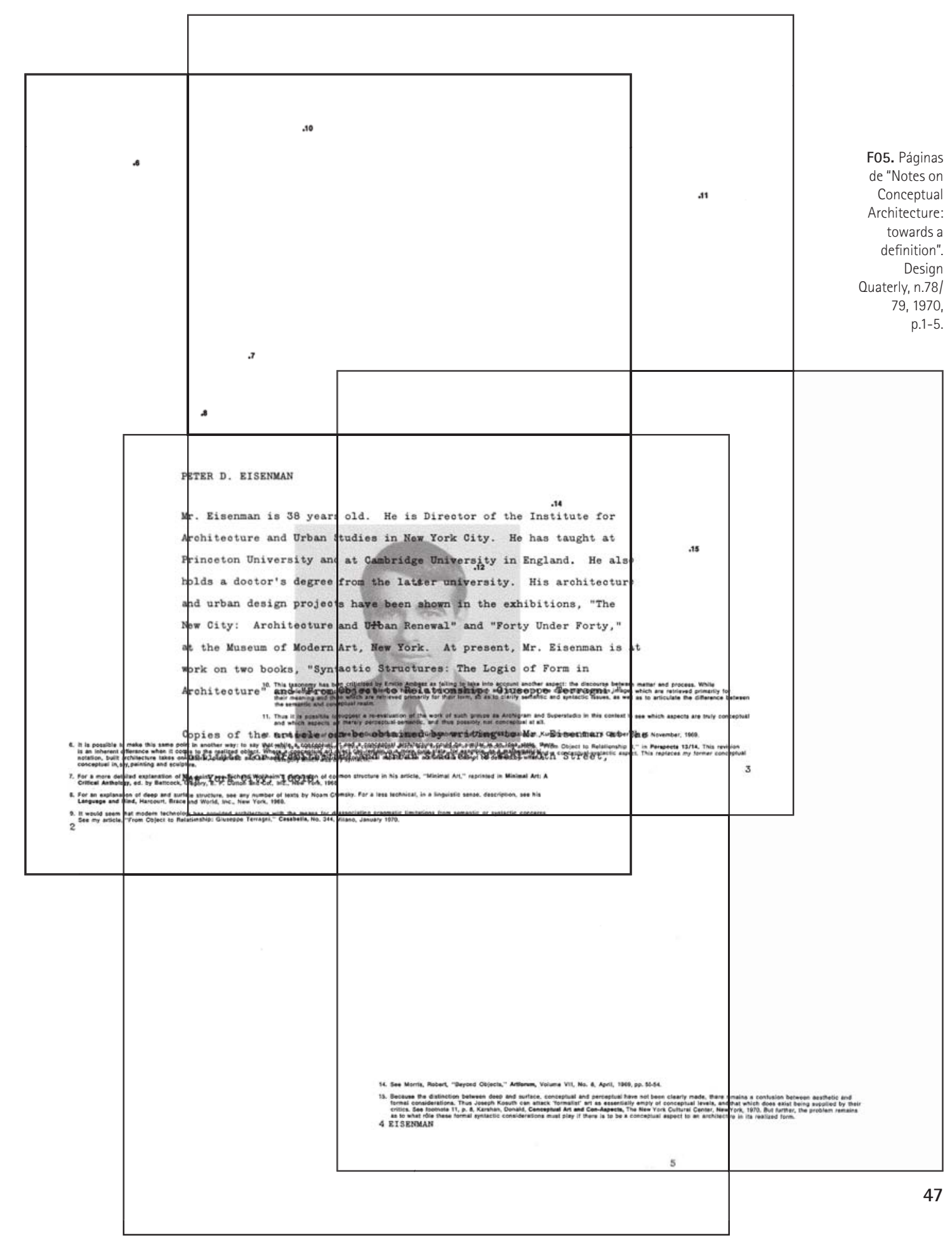



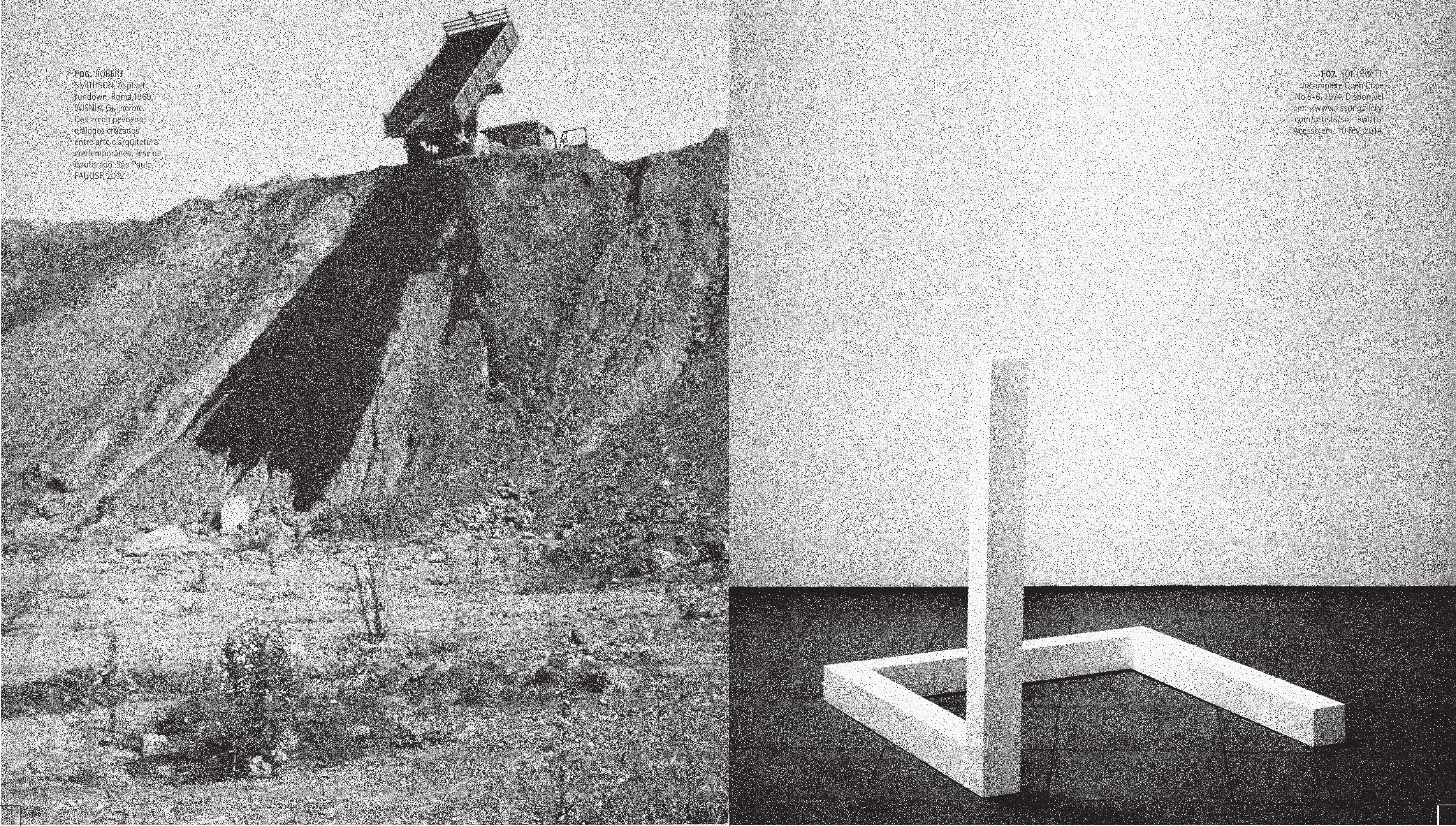
Eisenman de volta ao seu país com olhos de estrangeiro e, aflito, quer transformar o que vê com as ferramentas que trouxe na bagagem. Quer que seu ofício se construa a partir de cálculos e estratégias mentais operadas a partir daquilo que acredita ser a chave para libertá-la de sua submissão. Diante do cenário hostil que vê à sua frente, procura por caminhos paralelos e, da filosofia, da linguística da teoria da informação e da arte produzida por seus conterrâneos, toma elementos emprestados para a sua própria reflexão. Dirão alguns mais tarde que se trata de um assalto, outros, de invasão, falsificação, ou ainda, de uma fuga. Mas naquele momento as paredes do labirinto já não são mais tão sólidas como antes. Tornaram-se frágeis e bambas, com frestas sendo abertas em diversos pontos (às vezes à força, é verdade), ensaiando o processo de liquefação (ou sublimação ${ }^{17}$ ) que um pouco mais tarde se tornará evidente.

Nessa fragilidade de fronteiras, Eisenman não é o único a pisar em território que, supostamente, não lhe pertence. Muitos outros arquitetos passam a cruzar transversalmente os caminhos, ampliando uma movimentação que aos olhos reguladores e ordeiros da teoria e da história da arquitetura moderna, muitas vezes era tido como caótica e destrutiva. Ao mesmo tempo em que Eisenman olha para a arquitetura como um problema conceitual-formal, ao invés de construtivo e técnico, alguns artistas americanos, em um movimento contrário, como Robert Morris, Donald Judd, Dan Flavin e SolLe-Witt, são vistos construindo formas e espaços arquitetônicos, utilizando sistemas de iluminação de galerias ${ }^{18}$, fazendo cálculos para progressões seriadas de formas geométricas, ou ainda, "como Robert Smithson, Michael Heizer, Walter De Maria e Richard Serra, (...) dobrando grossas chapas de ferro em estaleiros navais, vestindo botas e capacetes, comandando helicópteros, tratores e escavadeiras, movimentando terra e orientando o trabalho de equipes de operários”.
Dos caminhos trilhados pela arte, Eisenman analisa os da chamada arte conceitual, centrando maior esforço na obra de Sol LeWitt - em dialogo, inclusive, com dois textos do artista cujos títulos são análogos, "Paragraphs on Conceptual Art" e "Sentences on Conceptual $A r t " 20$-, e tentando compreender o problema da formalização conceitual e física. "Em certo sentido, a arte conceitual é um modelo para nunca ser realizado em um objeto final, e, portanto, talvez seja possivel uma aproximacão de um verdadeiro estado conceitual. A ideia de que os objetos físicos podem ser processados totalmente conceitualmente não deve estar em questão. Também não deve a ideia de que para ser conceitual na arte e na arquitetura o trabalho deve permanecer em um estado de ideia. 0 que está em questão, e o que a arte conceitual mais deixa de levar em conta, é que a própria realidade física tem um aspecto conceitual”21.

Suas observações não são a de um crítico de arte, mas a de quem tenta formular uma teoria para a arquitetura. Do pensamento de uma disciplina, volta-se à outra trazendo elementos que, mesmo que como mera comparação, induzem um rearranjo de forças que a redefine. Não se trata nesse caso, portanto, de uma fusão de campos, mas de um redesenho de bordas, movimentação que contamina ambos os lados com o material do outro. Eisenman tem consciência da distinção de disciplinas e parece, de fato, ter nesse reconhecimento mais um elemento para a sua construção.

"Não há aspecto conceitual em arquitetura que possa ser pensado sem o conceito dos objetos pragmáticos e funcionais, caso contrário, não se trata de uma concepção arquitetônica. (...) Para se conceber algo conceitual em arquitetura é necessário tomar os aspectos pragmáticos e funcionais e colocá-los em uma matriz conceitual, onde sua existência essencial não é mais interpretada a partir do fato físico de ser um banheiro ou um armário, mas sim o aspecto funcional banheiro ou armário tornando-se secundário, para alguma leitura primária, como uma notação em um contexto conceitual”22. “(...) A fim de se 
aproximar de uma intenção conceitual, as formas que são percebidas deveriam conter uma estrutura dentro da sua presença física que teria a capacidade de levar o espectador a partir da percepção sensorial (imediata), a uma atitude conceitual, e, ao mesmo tempo, exigir desta estrutura uma capacidade de suprimir a possivel primazia de uma resposta sensual; para proporcionar um meio pelo qual relações conceituais são concebiveis como independentes de relações reais”.23.

Atenta para as diferenças entre a arte e a arquitetura no que diz respeito à concepção, à sua realização como fenômeno e, além isso, à interpretação - algo que o projeto desenha como possibilidade, mas que trilha caminhos que, para o desespero do ímpeto controlador da arquitetura, não pode prever -, a busca por uma definição da disciplina feita pelo arquiteto transparece uma fundamental preocupação com a ideia de comunicação. Em um texto posterior, cujo título anuncia a continuação do primeiro - Notes on Conceptual Architecture II A, no qual faz a crítica (ou autocrítica) à aplicação da linguística no pensamento sobre a arquitetura -, diz:

"Há um outro nível de informação que parece existir em qualquer configuração, que é mais dificil de sistematizar. Isso diz respeito algo na natureza do espaço arquitetônico que poderia ser considerado arquetípico. Isto é, a capacidade de um determinado desenvolvimento de forma e espaço de sugerir um nivel de informação formal que não pode ser entendido a partir de uma indicação da geometria real isolada, mas é proveniente tanto das implicações que são espacialmente inerentes à geometria real e a partir da capacidade do indivíduo no espaço para receber esta informação. (...) em arquitetura toda experiência do espaço é real e não se pode ter uma experiência virtual pe se. Aqui, um problema central para a arquitetura: tudo é real e nossa relação com ela é primeiramente real. Agora, se postula-se que toda a realidade física tem inerente a ela uma capacidade para o oposto, ou um estado virtual, por causa da capacidade de certas relações espaciais para apresentar um potencial continuum do real para virtual, então de alguma forma, devemos ser capazes de levar esse fator em conta (...) porque essa dialética entre real e virtual pode ser ativa mesmo se não foi concebida ou interpretada de forma consciente" ${ }^{24}$ Surge aqui, como preocupação de importância central, o potencial diálogo entre a forma realizada de uma construção (lida e interpretada como arquitetura) e o ambiente de projeto no qual as relações espaciais desse espaço foram, como mera possibilidade, objeto de um raciocínio. 0 espaço "real", que não é apenas a visualidade, mas sim as múltiplas sensorialidades, o tempo e maneira de um deslocamento, a interpretação que se faz a partir desses elementos etc, pensado como ambiente fértil de informação.

Mas, além, obviamente, daquilo que os textos de Eisenman trazem de elementos que me ajudam a construir o percurso do personagem, outro fator, não menos importante, não poderia deixar de ser notado e trazido para esse mapa: a forma com a qual ele apresenta Notes on Conceptual Architecture: Towards a Definition. Publicado em um periódico especializado ${ }^{25}$, o ensaio se apresenta como um conjunto de páginas brancas pontuadas por números que remetem às notas de rodapé de um texto que não pode ser lido, a não ser que, seguindo o convite feito na última página onde um endereço postal é exibido, se entre em contato com o arquiteto ${ }^{26}$. Fica claro através desse artifício, além de uma intenção mais evidente, a conclamação da participação do espectador no estabelecimento de comunicação com o autor, algo pouco usual em ensaios e artigos dessa natureza: uma profunda preocupação com a construção da linguagem que, como se vê nessa publicação e nos projetos e construç̃es que começam a ser desenvolvidos, é constantemente tensionada e testada ao limite do rompimento, explorando não somente, no caso específico desse ensaio, a produção de sentido a partir dos significados da palavra, mas também através da visualidade do texto no papel e das relações que se estabelecem entre os elementos impressos e a forma da página. 
Simultaneamente ao movimento que executa procurando a definição da chamada "interioridade" ou "estrutura profunda" ${ }^{27}$ na arquitetura, Eisenman descobre que ler e projetar arquitetura são ações de naturezas similares e intimamente relacionadas, que fazem parte do mesmo processo de interpretação, que são ambos raciocínios respeito da forma, do espaço, do programa, da estrutura, da téc nica etc., que transformam construção em arquitetura, ocorrência em linguagem e sistema. Seu proto-método de análise se converte em modo de projetar a arquitetura, realizando, de certa maneira, aquilo que ele busca nesses primeiros anos como arquiteto, ou seja, formular uma ferramenta que pense a arquitetura e seja traduzivel de maneira lógica e objetiva, excluindo-se julgamentos baseados na ideia de tradição, estilo ou preferência estética. 0 que nesse ponto ele atinge talvez não possa exatamente ser chamado de teoria talvez nem mesmo utilizando um termo do próprio Eisenman no último capítulo de sua tese, uma "open-ended theory" ${ }^{28}$, dada a 27. EISENMAN, Peter. "Notes on Conceptual Architecture II A". In: EDRA 4: Fourth International EDRA Conference. 1973, p.322.

8. "A Teoria deve abandonar ambos, a tradição histórica do séc. XIX e a tradição polêmica do séc. XX. Deve-se de alguma forma, para se ter alguma validade, estabelecer um sistema de prioridades baseado na consistência lógica. A teoria, em suma, deve se envolver com a compreensão de principios e não com a codificaçăóo dos principios. Ela e um esclarecimento de fundamentos,

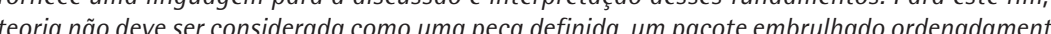
(T) formal basis of modern architecture. Baden, L. Müller, 2006, p.353. Traducâao nossa. potencial inadequação do termo. Construido a partir de investigações formais realizadas no desenho, por considerações que não apenas se expressam através dos diagramas, mas que, de fato, emergem deles, seu modo de análise e discurso se aproxima do seu modo de fazer e pensar a arquitetura no ambiente de projeto, um hibridismo entre verbal e não-verbal que conecta pensamentos de naturezas distintas. 0 desenho dos diagramas e dos textos deixa o papel que inicialmente lhe foi dado, o de apenas explicar a configuração formal de realizações arquitetônicas, para assumir o protagonismo do processo: uma reconquista de território, feita da aliança com a discursividade do verbal.

A casa, programa caro à arquitetura, cuja concepção está imbricada de maneira tão fundamental com uma função, a de abrigar, é o objeto de uma sequência de estudos que acompanham, ou melhor dizendo, que participam do esforço de Eisenman em pensar as bases da arquitetura e, a partir delas, definir a autonomia da arquitetura enquanto linguagem ${ }^{29}$. Daqui em diante se desenha um longo caminho de mais de quinze anos no qual o programa "casa" será trabalhado, tendo a função "abrigar” não como princípio, mas como

29. Em entrevista a Hanno Rauterberg, Eisenman disse: "Para mim a arquitetura começa uma vez cultura A arquitetura nos permite ter experiências que nem o cinema nem a literatura podem dar". RAUTERBERG, Hanno. Entrevistas com arquitetos. Rio de Janeiro, Viana \& Mosley, 2009, p.41. 
mais um elemento em um raciocínio formal. Entendendo a caminhada como processo, reafirmando o compromisso com o objetivo traçado alguns passos atrás, o arquiteto se vê na obrigação de descrever e analisar os próprios passos (como quem se explica diante de um espectador desconfiado), recorrentemente voltando às mesmas questões já delineadas: "Muito da obra da teoria da arquitetura moderna esté envolvida com um dilema básico porque ela se recusa a reconhecer problemas da forma como predicado de qualquer coisa, exceto ideias de transformação social e tecnológica ou como uma questão de estilística e especulação estética. (...) A configuração da forma pode, por exemplo, ser considerada como um problema de consistência

lógica, como uma consequência da estrutura lógica inerente a qualquer relação formal. A configuração da forma, nesse sentido, é mais do que a satisfação de requisitos funcionais e mais do que a criação de objetos esteticamente agradáveis, mas antes a exposição de um conjunto de relações formais" 30 .

A partir de um mesmo princípio, mas com diversas alterações e alargamentos no conjunto de regras determinadas, a série de casas se desenvolve ao longo desse caminho como um pensamento sobre a arquitetura. Série não apenas como sequência cronológica, mas como O. EISENMAN, Peter. "Cardboard Architecture". In: Eisenman insid conjunto composto de partes que se colocam como continuação e, ao mesmo tempo, crítica das anteriores. Poderia ser dito que formam uma trajetória razoavelmente reconhecível, não apenas para quem a olha daqui de longe, mas, talvez, no seu próprio construir-se (a consciência temporal de um gesto). A enumeração dos componentes desse conjunto, feita pelo próprio Eisenman, poderia ser comparada ${ }^{31}$ à enumeração de sinfonias feita por um músico, reforçando o caráter que o arquiteto tentou imprimir ao seu trabalho.

Tendo a geometria como princípio e a perspectiva axonométrica como principal técnica de representação, uma impressionante quantidade de diagramas desenhados para cada um dos

projetos registra cada operação, cada decisão projetual que conforma volumes, planos, transparências e vazios. 0 processo de projeto, com todas as suas supostas etapas detalhadamente descritas, ganha contornos definidos e tem para cada uma das suas operações - antes livres de qualquer restrição, de qualquer orientação que não a da misteriosa dinâmica do gesto - um limite determinado e uma lógica reconhecível. 0 resultado é um encadeamento de quadros de uma sequência fílmica que narra o processo de projeto e desenha um caminho que explica a configuração da obra.

31. Como fez Rafael Moneo em: MONEO, Rafael. Inquietação teórica e 
de indexicalidades que apontem para as ações do projetista, estabelece relações com as obras que a precederam ${ }^{32}$ - tanto as do próprio Eisenman como as de Le Corbusier, Terragni, Palladio etc. - e com o raciocínio desenvolvido ao longo de todo o percurso. No caso da House $I V$, por exemplo, o fato de não er sido construida em nada altera a sua posição dentro do conjunto, pois o que está em

jogo nesse caminho, mesmo que assumida a diferença da arquitetura para outras formas de arte, ou seja, a de estar inescapavelmente ligada à materialidade, não é a apreensão visual da obra construída, mas as relações formais que na sua concepção diagramátic são apontadas como possibilidades. Se dentro de um raciocínio um diagrama conduz a construção do próximo, na arquitetura uma obra é um pensamento sobre as anteriores e se coloca na base da configuração de uma construção futura.

Assim, embora atento às importantes considerações de Anthony Vidler, um dos

32. Em entrevista a Francesco Dal Co, Eisenman faz uma colocação importante a respeito da tradicăo em Arquitetura: "FDC: (...) que nós definimos como a superação da representação a través do trabalho da desconstrução, se traduz em realidade nexaltação da primazia da estrutura formal, exatamente como ocorre na Casa del Fastio de Terragni, que te fascina por seu Sim, mas com uma condic ão: agora nós nõ̃o estamos falando de mais Terragni, de suas fachadas, mas a minha interpretacâo de Terragni. Esta e a minha interpretação e não tem nada a ver com a objetividade da obra de Terragni. Terragni está par Palladio assim como estou para Terragni. A Casa del Fascio uma homenagem a a Palladio, como a minha House ll é ume "Peter Eisenman: Dall a casa del fascio al monumento all'olocausto Una conversazione intorno al significato e ai fini della pratica dell-architettura (e qualche ricordo)". Casabella, vol. 64, n. 675 fev. 2000, p.34. Traduçăa noss

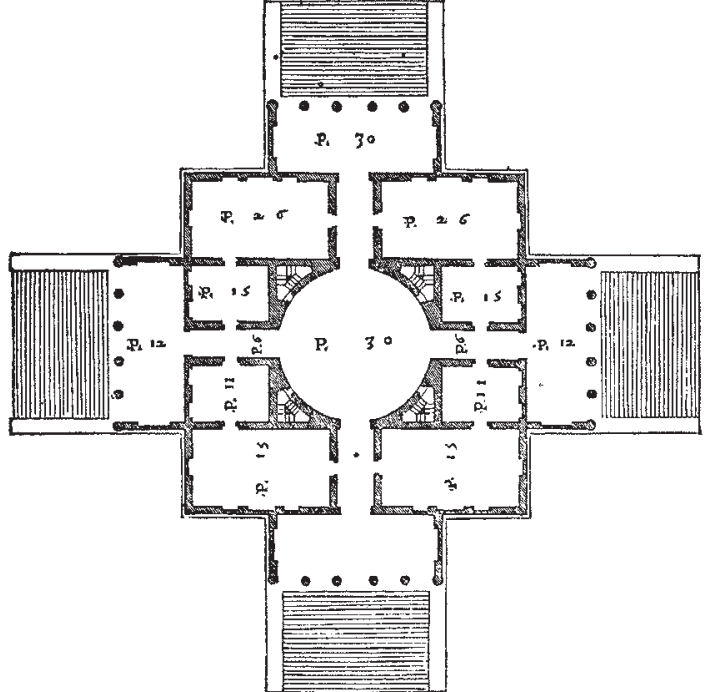

F08. ANDREA PALLADIO Villa Rotonda, 1570
GANDELSONAS, Mario "From Structure of an Architectural Language". House X. New York,
Rizzoli, 1982 .

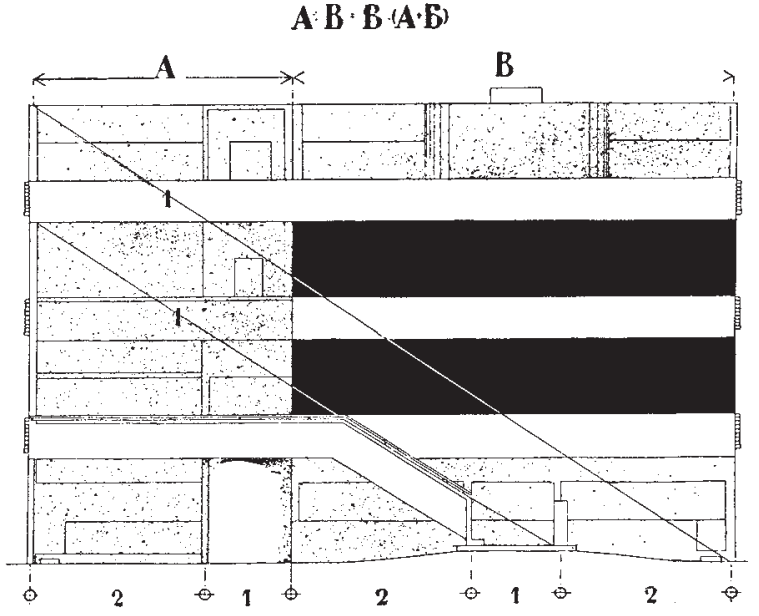

F09. LE CORBUSIER Villa en Garches
1927. BOESIGER, W. GIRSBERGER, H. Le Barcelona, Gustav
Gili, 197

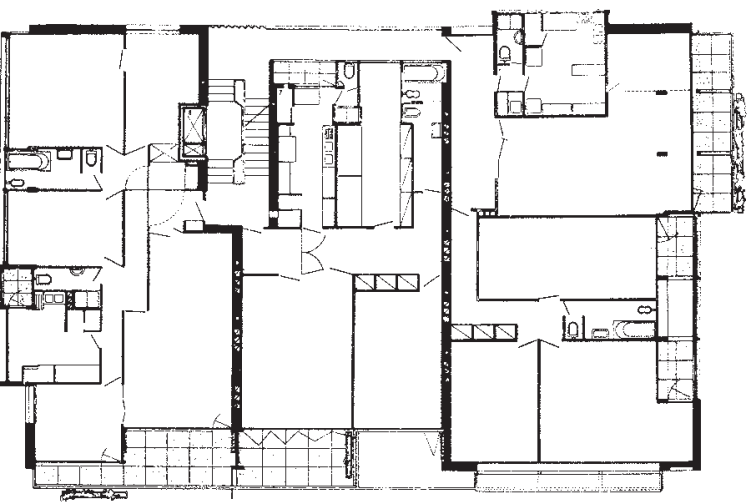

. GIUSEPPE TERRAGN 1939. FRAMPTON Kenneth. "Frontalidaa
entea rotacion". In: Gwathmey, Hejduk, Meier. New York, Oxford
University Press, 1975 
primeiros alunos de Eisenman em Cambridge, e às recomendações que faz para a leitura da obra do seu antigo mestre ${ }^{33}$, assim como para o autodeclarado descolamento do contexto físico social, histórico etc., que marca de maneira radical essa fase de produção, ao olhar para os inúmeros diagramas das casas e da tese de doutorado, vejo um claro diálogo entre aquilo que se estuda em um projeto e aquilo que pode ser lido em outras obras suas e de outros arquitetos, algo que afasta a ideia de sistema fechado e de hermetismo que muitas

vezes é atribuída à obra de Eisenman sobretudo a desse período. A suspensão criada no ambiente de projeto - com o isolamento de variáveis e com uma maneira específica de manipulá-las poderia ser comparada a de qualquer outra construção como, por exemplo, dos textos discursivos da crítica. Da mesma maneira, cada um dos componentes da série de desenhos não pode ser visto com um fim em si mesmo, não querendo representar nada, não visando qualquer construção ${ }^{34}$, ou ainda, não objetivando qualquer fim, como
33. "(...) dentro de tal contexto intelectual qualquer semance de unidade nas origens e nos fins, ou na sua sequatenç̃o para lapsos, linhas interrompidas, proposicões irreconciliáveis, e erupcões de conteúdos nõo sistematizáveis na aparente suavidade e ininterruptos processos de transformação e desenvolvimento. Isso deverá ser especialmente pertinente para a leitura dos projetos e textos de Peter Eisenman, que parecem deliberadamente evitar, comecos e fins. forma e conteúdo como um caminho de rejeição da história inscrita na tradicão arquitetônica. colocado consistentemente contra analogias antropomórficas, fechando sistemas formais, e derivaçôes funcionalistas, seus projetos de implicito retorno ao sistema clássico tepresentaçāo, negando qualquer autenticidade para

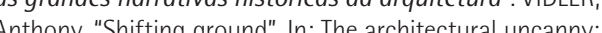
essays in the modern unhomely. Cambridge. The MIT Press. 992, p.118. Tradução nossa. em alguns trabalhos de Sol LeWitt ${ }^{35}$, mas como estudos sequenciais a respeito da forma, como investigações que, assim como nas contra-construções de Theo Van Doesburg, efetuam o isolamento provisório de variáveis - como, por exemplo, a da ação da gravidade - em busca de uma nova espacialidade ou de possibilidades espaciais que, pela imediata submissão a esses princípios, talvez não pudessem ser imaginadas ${ }^{36}$. 34. ARANTES, Otilia Beatriz Fiori. 0 Lugar da Arquitetura de São Paulo, 2000, p.68.

35. ALLEN, Stan. "Trace Elements". In: Tracing Eisenman. New York, Rizzoli, 2006, p.58.

36. Esse entendimento será particularmente importante no pensamento a respeito da arquitetura que se faz partir de novas ferramentas, como os modelos eletrônicos de Eisenman, ou de métodos não usuais, como os papéis amassados e curvados de Frank Gehry.
F11. SOL LEWITT, Variations of Incomplete Open Cubes, 1974.

Disponivel em: < <ww.martinmarek.name/variationsof- 1974 Whe

F12. THEO VAN DOESBURG, Contra-constructie, 1923. STRAATEN, Evert van. Theo van Doesburg: Peintre et architecte.
VARIATIONS OF IMCOMPLETE OPEN CUBES

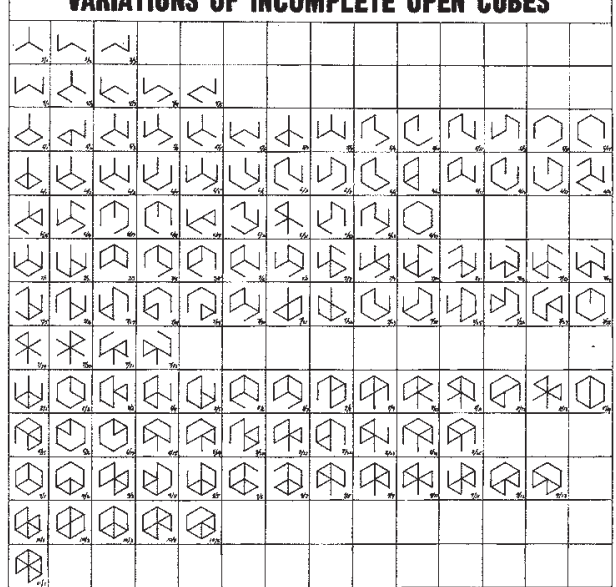


Sobre As Metamorfoses, de Ovídio, Chcheglóv fez uma análise que trago para cá (um furto que considero justificável) como mais um elemento que me ajuda a pensar o ambiente que Eisenman cria nessa sequência de desenhos feitos sob as mesmas bases: “(...) A impressão mais viva que fica de As Metamorfoses é a da unidade e parentesco de tudo no mundo, objetos inanimados e seres vivos. Por mais distantes entre si que estejam os objetos do mundo real, aqui eles são mostrados de tal modo que parecem criados do mesmo material. Nisso consiste a unidade do poema de Ovídio, tão variegado à primeira vista. 0 poeta pode misturar mitos de diferentes ciclos, tratar ora da guerra de Tróia, ora o voo de Faetonte, ora de formigas e lagartos; em tudo o que ele conta, transparece de um modo à primeira vista misterioso a unidade e continuidade do Universo. 0 grande e o pequeno têm o mesmo direito à atenção e estão construídos segundo as mesmas leis. 0 parentesco admirável de todos os objetos se manifesta, por exemplo, no fato de quão pouco é necessário no mundo de Ovídio para que um homem, por exemplo, se transforme numa ave e uma ave num homem. Os objetos se transformam muito facilmente uns nos outros; ocorre não se sabe que deslocamento insignificante de partes, às vezes uma simples mudança de nome - e a transformação está consumada. É mundo real nosso conhecido, mas como que examinado através de certo vidro peculiar e fantástico, que permite ver os objetos de modo novo"37. 37. CHCHEGLÓV, I. K. "Algumas caracteristicas da estrutura de As Metamorfoses de Ovidio". In: SCHNAIDERMAN, B Semiótica Russa. São Paulo, Perspectiva, 1979.

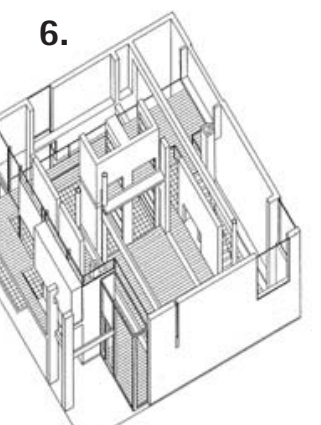

I (1967-68)

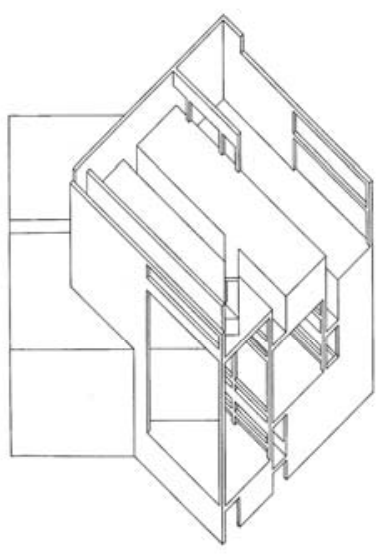

$\mathrm{V}(1972)$

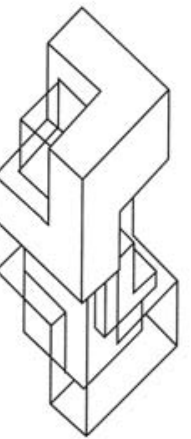

11a (1978)

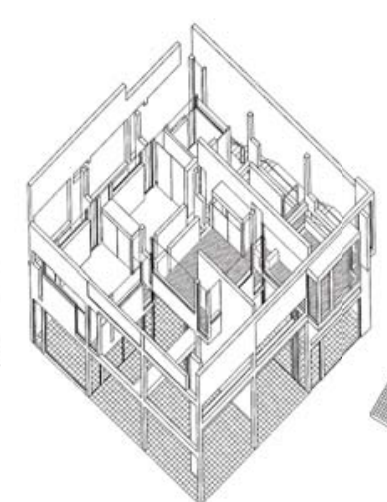

II (1969-70)

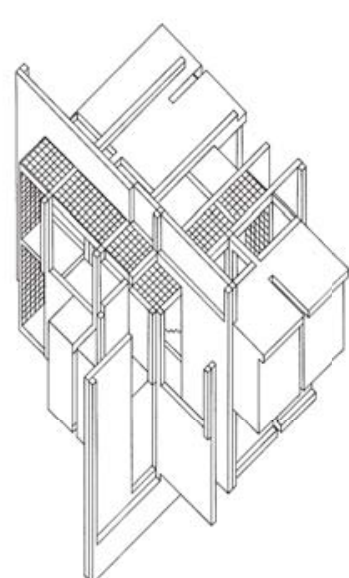

VI (1972-75)

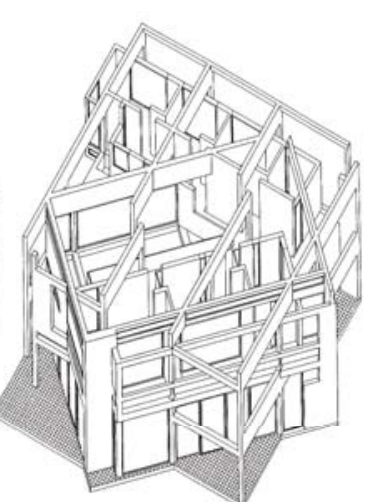

III (1969-71)

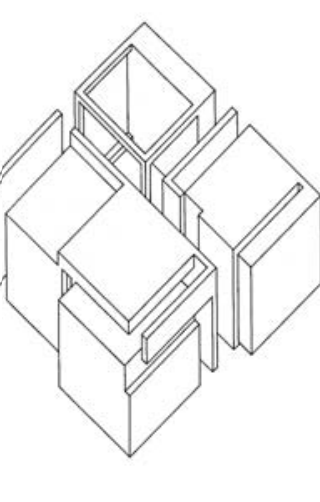

VIII (1973)

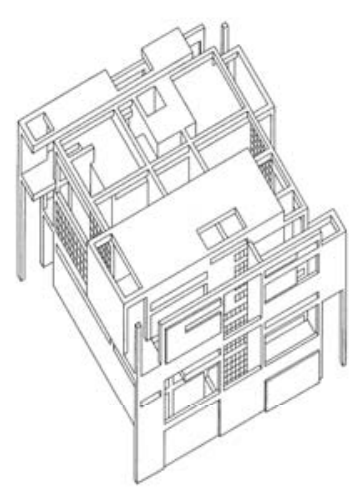

IV (1971)

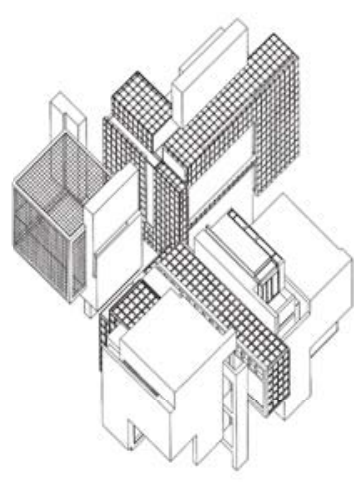

X (1975)

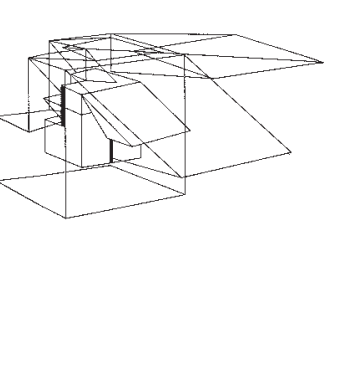

EL EVEN ODD (1980)

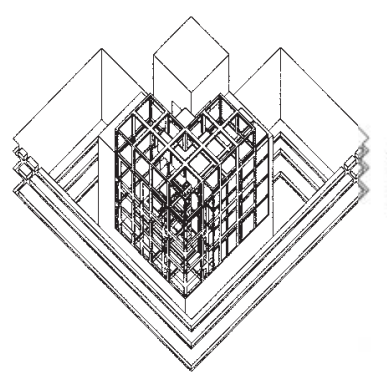

FIN D'OU T HOU S (1983)

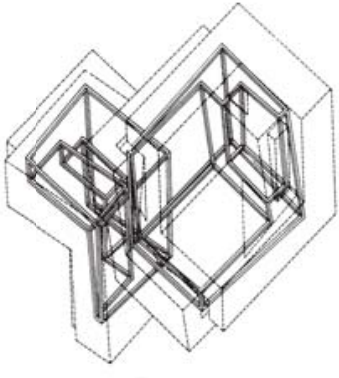

GUARDIOLA (1988) 


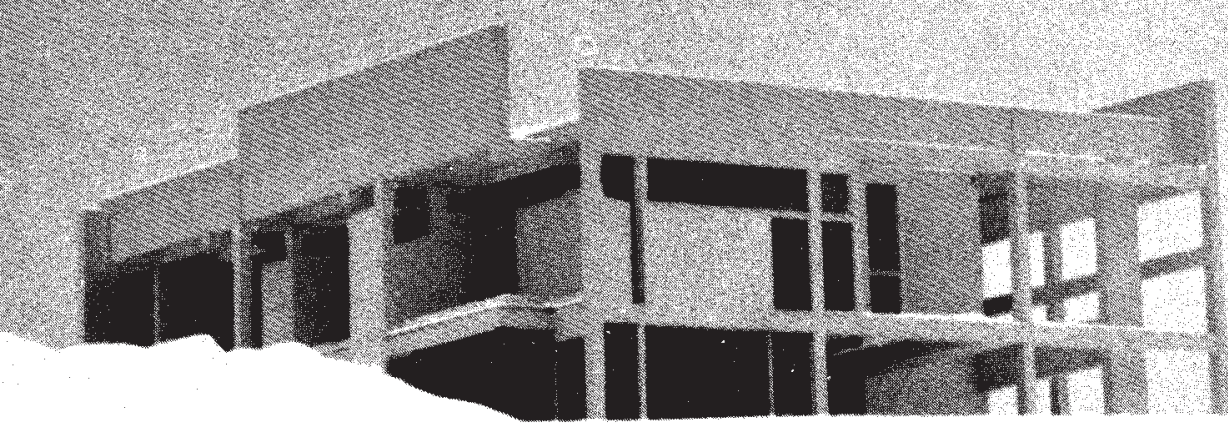

7. No contexto do ambiente criado pelos projetos, os elementos tradicionais da arquitetura - pilares, vigas, paredes, janelas, etc. - deixam de ser, segundo o discurso construído, tratadas apenas como representações simbólicas da resistência à força da gravidade ${ }^{38}$, da divisão entre o dentro e o fora, da construção de relação com a paisagem ou do cumprimento de exigências funcionais como a iluminação e ventilação. Como queria Eisenman, a função passa a estar incorporada de maneira subordinada em um conjunto de relações formais trabalhadas no ambiente de projeto, com a construção remetendo a ele a partir de indexicalidades como, em exemplos um pouco mais evidentes, no cruzamento diagonal de elementos estruturais (que muitas vezes só estruturam a si mesmos) na House III, indicando um movimento de rotação, ou na intersecção de grandes planos na House VI.

Como uma simples ironia e, ao mesmo tempo, como elemento de construção do discurso, as duas primeiras casas - e, por extensão, também as seguintes - ganham o título provocativo de cardboard architecture, uma analogia entre a aparência das casas construídas e os modelos físicos tradicionalmente usados nos processos de projeto, analogia enormemente reforçada pelas famosas fotografias preto-e-branco ${ }^{39}$ da House II, nas quais a casa é vista à distância no topo de uma elevação de terreno coberto de neve e com o fundo homogêneo de um céu nublado, abrindo a possibilidade de dúvida com relação à imagem: trata-se de uma fotomontagem com um modelo ou de uma fotografia de uma construção? Apesar de recorrentes interpretações que atribuíram à obra uma pretensão à imaterialidade - ou uma dispensa da necessidade de construção real -, o que a descontextualização de elementos, o tratamento neutro das superfícies, assim como o uso do polêmico título indica é, novamente, uma preocupação com a apreensão e interpretação da obra construída, tentando tira de campo associações por contiguidade que eventualmente possam ser feitas: um pilar, lido como elemento que suporta as cargas da estrutura, ou uma parede de tijolos, lida a partir de sua textura relacionada a uma específica tradição construtiva. 


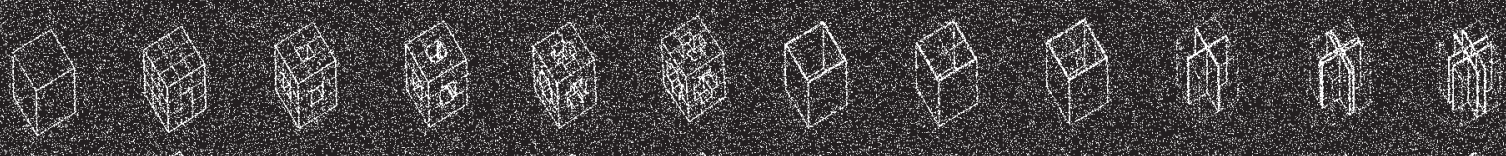

1.

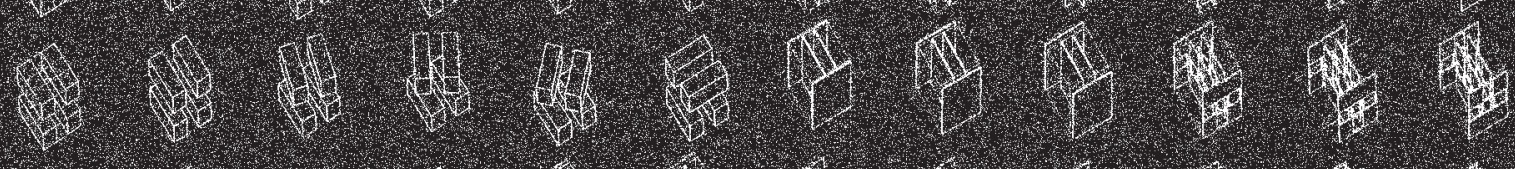

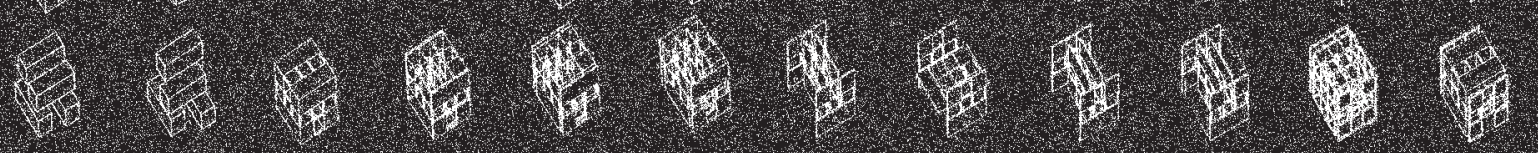

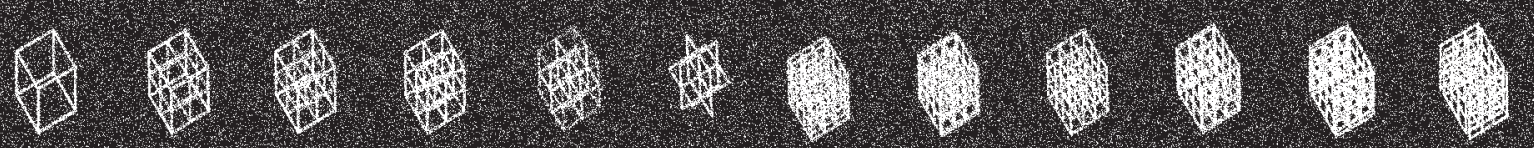

$4 \div 000000609$

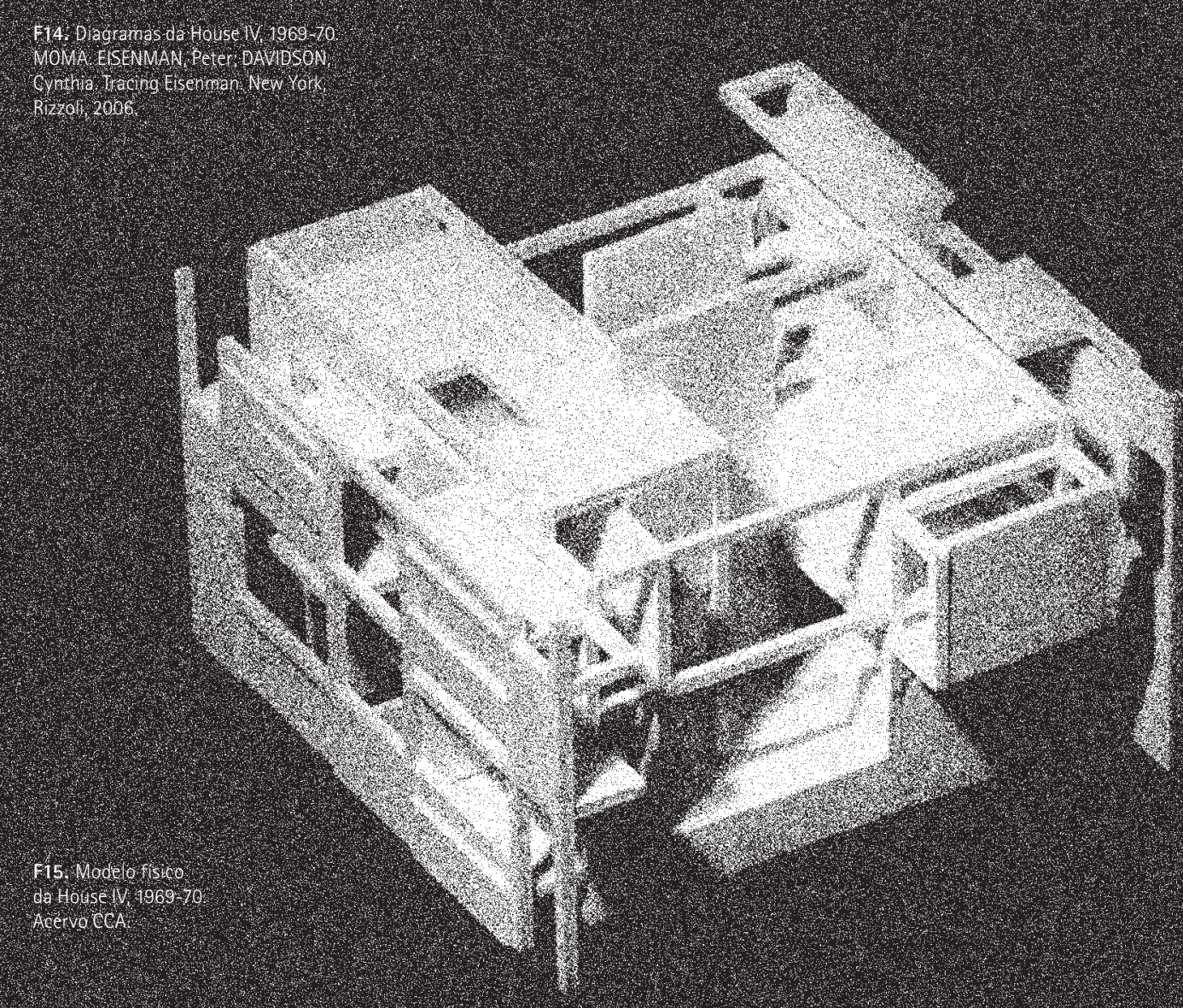

"Um aspecto do primeiro passo foi uma tentativa de reduzir ou retirar o significado existente das formas ditadas pela função, de modo que as formas podem ser vistas como uma série de marcas primitivas. Isto foi tentado através de uma manipulação da relação de cor, textura e formato das formas construidos. Formas brancas são usadas na casa para mudar nossa percepção visual e concepção de tais formas; da percepção de uma arquitetura real, tangivel, branca, volumétrica, para a concepção de uma abstração (...); da polêmica do 'branco' dos anos 1920 para a neutralidade do cartão"

Em um momento posterior, ao reconstruir sua própria trajetória em um livro, Eisenman chama a atenção novamente para esse ponto: "Nas primeiras casas, os diagramas são entendidos como sem cor e essencialmente despreocupados com a materialidade. Essa imaterialidade foi expressa como parte da codificação da casa, como uma representação do processo diagramático. Desde a House VI não ser tratava mais de uma representação do processo diagramatico mas, de fato, o processo em si, outra codificação foi necessária, isto é, a coloração não apenas dos diagramas como também da casa"ł1.

A partir dos mesmos princípios e preocupações com a interpretação dos projetos e obras, a série se desenvolve como uma sequência de experimentos. Dentro dessa espécie de narrativa, textos, desenhos, modelos e construções - elementos que mantêm certa independência, mas que se afirmam a todo tempo como partes de um conjunto dialogam com as realizações anteriores, demonstrando possibilidades não exploradas, e, de forma projetiva, com as que ainda serão realizadas, apontando possíveis desenvolvimentos. De um esquema de divisões proporcionais relativamente simples na House I (um princípio bastante presente na tradição arquitetônica, e detalhadamente

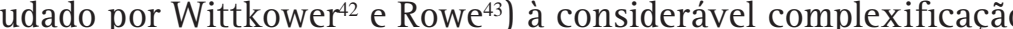
dos processos e princípios compositivos na House $X$, opera-se um jogo no qual o movimento de uma peça induz o posicionamento da próxima. Apesar dos diversos abismos que se abrem no entendimento

40. EISENMAN, Peter. "Cardboard
Architecture". In: Eisenman inside out: selected writings, 19631988. New Haven, Yale University Press, 2004, p.30. 41. ESEENMAN, Peter. Diagram Diaries. London, 1999, 77 Tradução nossa. 


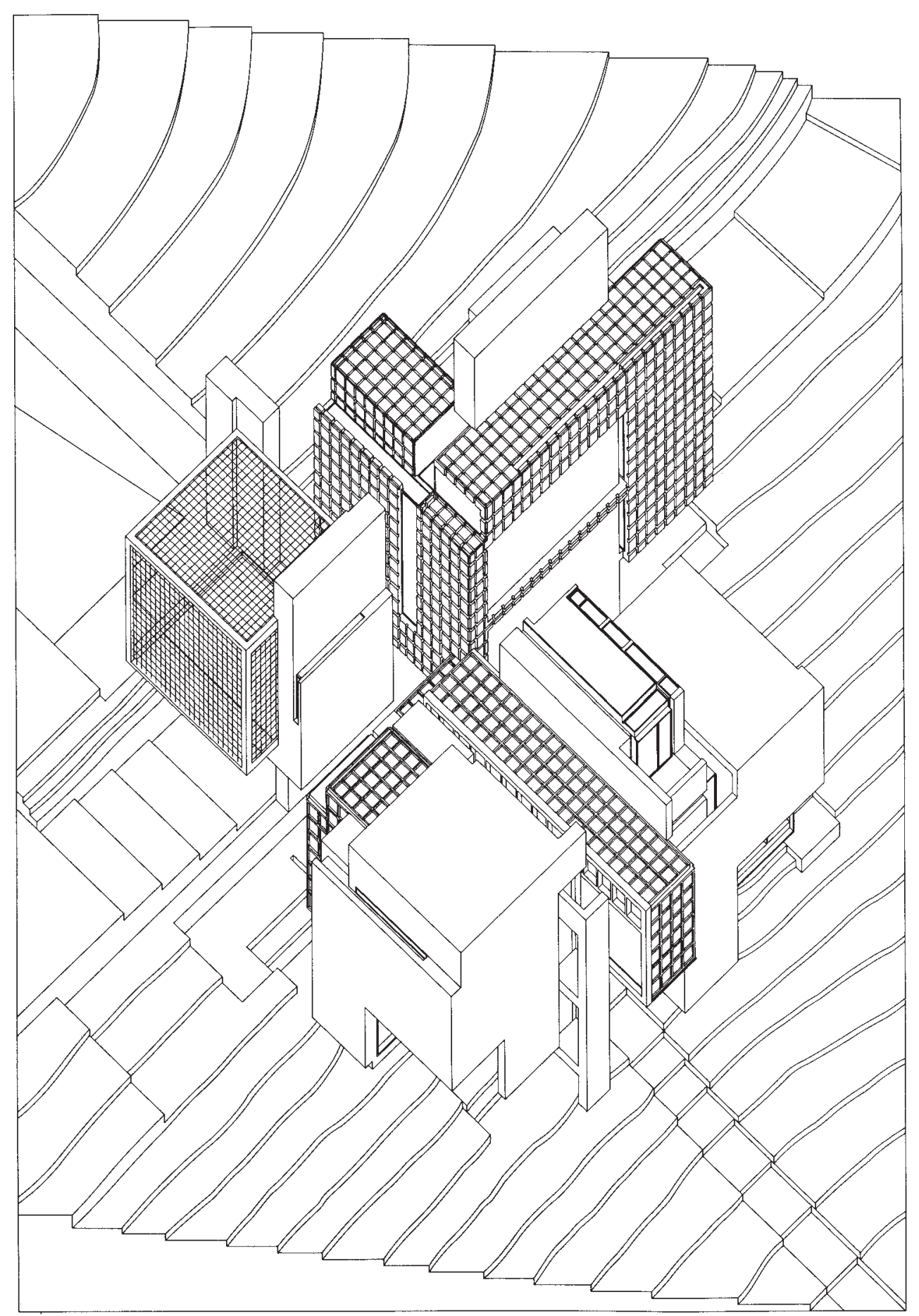

da sequência (uma tarefa que não é das mais fáceis, mesmo para um olhar muito atento), é possível detectar em cada ensaio, elementos herdados dos anteriores dando origem a novos resultados formais.

É preciso, entretanto, ressaltar que a ideia de sequência não deve ser entendida estritamente como cronologia, e a de percepção de influência de um movimento não pode ser tida a partir do princípio de causa e efeito. Trata-se de uma trilha repleta de bifurcações e becos sem saída, e não de uma linha reta na qual um evento sucede inequivocamente o outro. As operações de divisão de sólidos sobrepostos e a incorporação do resultado de suas somatórias na House I, assim como a exploração de outros volumes circunscritos no sólido da casa, que na House II surge como uma progressão de expansão vertical e horizontal, são reestudadas sob as mais diversas maneiras em todas as casas que compõem a série. Na House III, por exemplo, esses dois princípios são trabalhados de maneira razoavelmente clara e sintética (a despeito da complexidade do resultado), com o cruzamento de um grid espacial com volumes rotacionados, o que é retomado na House $I V$, mas com um grau de complexidade muito maior.

A própria maneira como o arquiteto se lança ao jogo, promove uma gradual "explosão do sistema" 4 , resultando em uma variação de processos na House X. Além, obviamente, da escala, uma diferença fundamental entre ela e suas antecessoras se dá na maneira como o problema é enfrentado, ou seja, na forma como o processo de projeto envolve e incorpora elementos, selecionando suas variaveis, delimitando seu campo de ação e definindo suas regras de transformação. A própria condição do terreno em declive já insere um dado que não estava tão presente nas outras casas - implantadas ou projetadas sem que o terreno interferisse claramente em seu jogo interno, o que contribui para a ideia de "realidade suspensa" 45 -, induzindo assim a adoção de uma variável que antes não estava em jogo, variável presente na representação de um plano inclinado como resultado de um corte de terreno em um dos diagramas que compõe a sequencia 


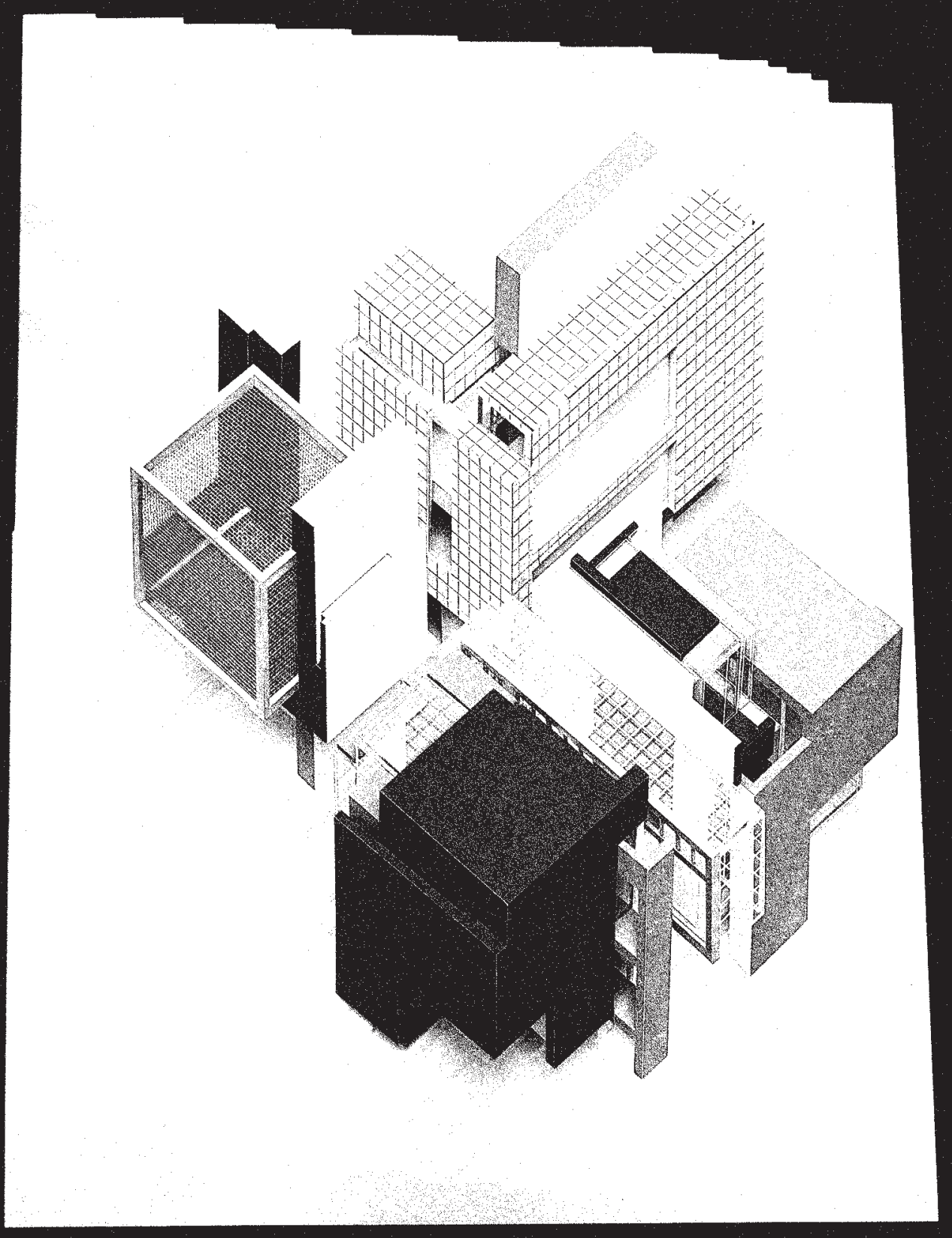

F17. Modelo axonométrico da House X, 1975.
EISENMAN, Peter. House X. New York, Rizzoli, 1982.

explicativa $^{46} .0$ volume virtual do qual deriva aqui sofre pela primeira vez a interferência de algo externo a ele: a topografia. Além disso, a maneira como os elementos são fracionados, reaglutinados, organizados e reorganizados a partir de um grid espacial aqui é feita de maneira mais complexa e com um número muito maior de subdivisões e deslocamentos que praticamente dissolvem a sua suposta origem. Ao invés disso, torna-se mais visível a leitura da origem em um paralelepípedo que teve uma de suas metades deslocada para baixo, leitura que, por sua vez, reforça a ideia de acomodação no terreno.

Por outro lado, a percepção da origem geométrica da composição se dá de maneira muito diferente nas axonométricas que acompanham a exposição (em comparação com as fotografias de modelos de estudo e com os cortes longitudinais). Isso não passa despercebido por Eisenman que, nas últimas páginas do volume faz uma ponderação a respeito do material exibido nelas: as imagens de um modelo construído para produzir, através da fotografia ${ }^{47}$, um efeito semelhante ao de uma perspectiva axonométrica. "O artefato final no processo de fabricação da House X é o modelo axonométrico. Ele foi feito, senão concebido, depois dos desenhos de trabalho serem concluidos e depois de ser decidido não prosseguir com a construção final da casa. Assim, pode ser visto como mia do objeto e a heurística e aproximada natureza do processo. (...) Usualmente, uma fotografia de um edificio é um registro narrativo de um fato - uma representação da realidade. Aqui a fotografia é a realidade do modelo; ela é a visão que revela sua essência conceitual como um desenho axonométrico. Mas enquanto a essência conceitual do modelo é um desenho, a da fotografia não. (...) Aqui, o círculo está fechado e a verdadeira realidade da casa permanece suspensa. $O$ modelo torna-se a aproximação heuristica final - o último ato de decomposição".

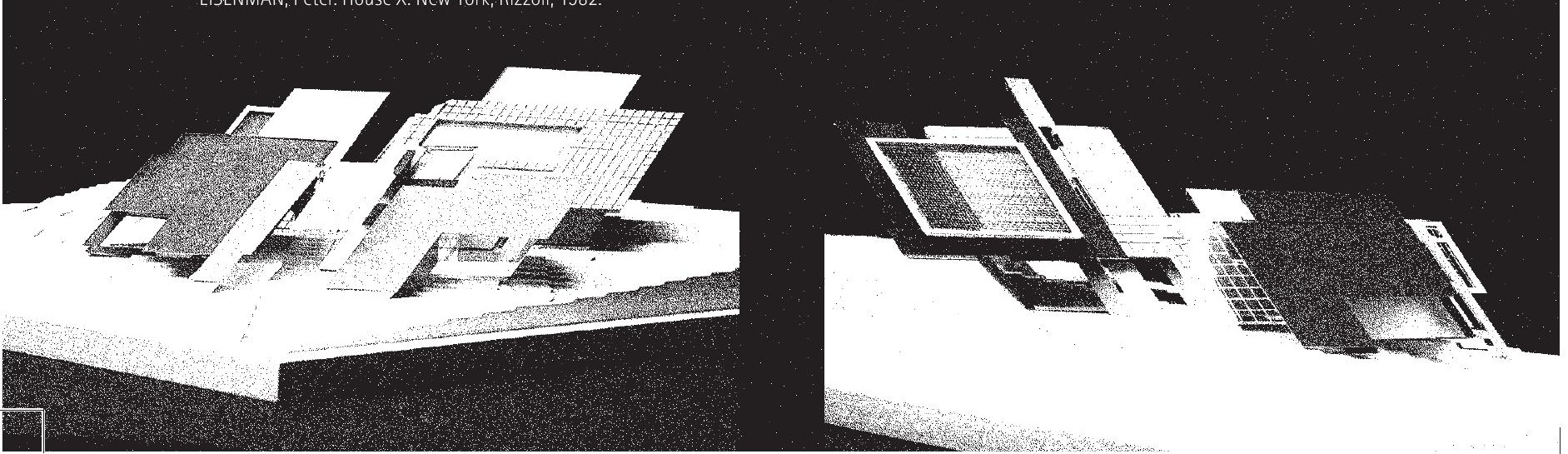


A fotografia desse modelo, assim como, obviamente, o próprio modelo, consolida-se como mais um ponto do mapa que desenho. Ela revela não apenas coisas a respeito do modo como a fotografia e as perspectivas axonométricas operam, mas também algumas das escolhas do arquiteto, algo que vai muito além de uma simples coleção de anedotas. Procurar revelar as escolhas significa procurar ir além dos resultados das operações, tentando reunir as variáveis recompor a própria equação. A escolha por projetar (e por demonstrar a validade de seus projetos) através de outros meios que não somente o da representação planta e corte, não é apenas uma escolha arbitrária, ela indica a opção pela retirada de cena daquilo que, entre outras coisas, segundo o arquiteto, impediu a arquitetura modern de estabelecer uma ruptura radical, ou seja, o predomínio do sentido da visão sobre qualquer pensamento a respeito da arquitetura ${ }^{49}$.

49. "O sentido da vista é tradicionalmente entendido com relação à visão. Quando uso o termo visão, estou me referindo áquela caracteristica peculiar da vista que liga o ato de ver ao de pensa o olho ao pensamento. Na arquitetura, a visão diz respeito a uma categoria especial da percep̧̧ão relacionada com a visão monocular perspectivada. A visão monocular do sujeito permite que todas as projeçōes do espaço se resolvam em uma unica superficie planimétrica. Por isso, não surpreend superficie bidimensional encontre na arquitetura um meio disponivel e insuficiente. Muito menos surpreende que a arquitetura desde cedo tenha começado a se adaptar a essa visão monocular racionalizadora, em sua própria materialidade. Qualquer que fosse o estilo, o espaço foi constituido como um constructo inteligivel e organizado em torno de elementos espaciais, tais como eixos, lagares, simetrias e outros. A perspectiva é ainda mais virulenta na arquitetura que na pintura devido às exigenncias imperiosas do olho e do corpo para se orientarem no espaço arquitetônico por por Brunelleschi da perspectiva linear (com um ponto de fuga) tenha ocorrido em una época de mudança de paradigma, quando a visão de mundo teocêntrica e teológica foi substituida por uma visão de mundo antropomórfica e antropocêntrica. A perspectiva tornou-se então o meio pelo qual a visão antropocêntrica se cristalizou na arquitetura subsequente àquela mudança de paradigma". ESENMAN, Peter. "Visöes que se desdobram: a arquitetura na era da midia eletrônica". In Uma nova agenda para a arquitetura: antologia teórica (1962-1995). São Paulo, Cosac Naify, 2006, p.60
A escolha pela utilização das regras da perspectiva axonométrica nos seus diagramas ainda nos revela uma preocupação com a construção de um processo de projeto analítico-descritivo, ao lançar mão de uma ferramenta historicamente usada para descrever coisas, devido à sua capacidade de representar no plano as três dimensões do espaço - que aqui é apenas uma interpretação feita pelo desenho - de maneira simultânea ${ }^{50}$. Trata-se de assumir o processo de projeto como um ambiente laboratorial, experimental, no qual investigações sobre a casa, a funcão, e, sobretudo, o espaço serão empreendidas, observadas e testadas, de pensá-lo como a delimitação de um campo, de um recorte no universo de possibilidades, criando assim a sua própria realidade e abarcando o tempo apenas na medida em que, sendo formuladas hipóteses, imagina possibilidades futuras, ressonâncias dos arranjos e relações estabelecidas, decorrências da realidade criada. E neste campo, diante dessas peças e desse modo de jogar, o arquiteto se coloca. A afırmação de Eisenman nas últimas páginas do seu livro expositivo da House $X$, a de que " verdadeira realidade da casa permanece suspensa", reforça a ideia de realidade como uma hipótese de trabalho, como uma delimitação de um espaço no qual determinados elementos interagem. Dentro de um continuum ${ }^{51}$ o ponto de vista é uma descontinuidade.

50. RAMOS, Fernando Vázquez 19211/2: Van Doesburg e (è) o vento que varre a Bauhas de Weimar nos anos 20: comunicação apresentada ao VII Fórum de Arte de Brasilia. Brasilia, 2009. 51. MACHADO, Irene. ; ROMANINI, A.V. Semiótica da comunicação: da semiose da natureza à cultura.
Revista FAMECOS, v. 17, n.2, p. 89-97, 2010, Porto Alegre, p.94. 
0 declive do terreno da House $X$ impõe ao rígido sistema, forças que até ali eram abertamente ignoradas ou deixadas em posição subordinada ao movimento geral dos elementos. Se na House V se ensaia (embora ainda timidamente) uma incorporação mais clara desse enfrentamento com algo até então externo à lógica formal, na House VI ele é rapidamente submetido àquilo que parecia ser de maior interesse, ou seja, a exploração da transformação de planos e volumes dentro de uma vertiginosa leitura da geometria nas perspectivas axonométricas. Os planos de apoio dessa casa, inclusive, recebem posteriormente um tratamento diferente das demais superfícies, sendo revestidos com uma cor vermelho-terra, quase como que dizendo que não faziam parte da casa, mas do terreno onde ela se apoiava. 0 volume dentro do qual as operações de transformação e derivação eram realizadas na House VIII, se parte em dois em um movimento de acomodação na superfície, mantendo-se uma "hipótese" formal que nela é anunciada: a relação entre quatro volumes cúbicos.

Mas o que importa aqui ressaltar é que no projeto da House $X$ a incorporação da topografia não se dá apenas em termos funcionais, ou seja, a necessidade de acomodar a construção no terreno, de permitir o deslocamento dos moradores de um nível para o outro, mas também em termos formais. Se nas casas anteriores o volume pousa sobre 0 terreno caracterizando ou uma independência ou uma intersecção, um enfrentamento - algo que fica bastante evidente na House V-, aqui o volume se deforma em um claro diálogo. Mas mais do que isso aqui as operações de transformação, a partir das quais cada uma da etapas se realiza, incorporam o deslocamento provocado pelo terreno como código. Os quatro sólidos cúbicos herdados da House VIII não apenas são deslocados verticalmente em função da acomodação, como também as transformações que se dão em cada um deles se fazem a partir de um princípio de oposição entre os volumes que foram deslocados para cima e os que foram deslocados para baixo. Assim os puros volumes cúbicos se transformam em complexas formas côncavas caracterizadas a partir de vazios e transparências, com as do topo se abrindo para cima e as da base para baixo.
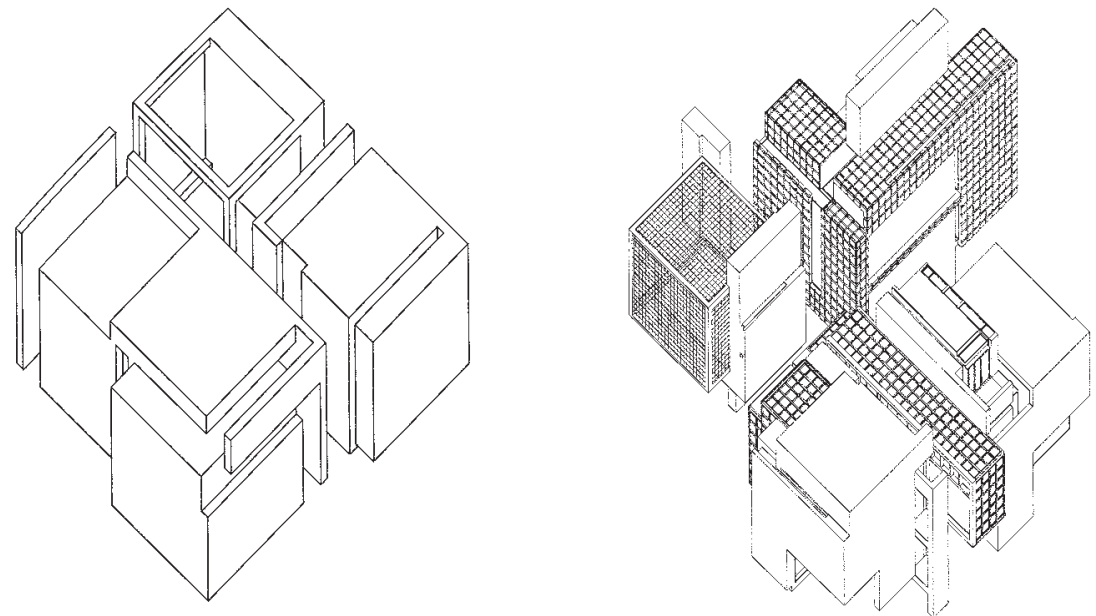

F18. House VIII House
GANDELSONAS, Mario. "From
Structure of an Lenguage"."in. House X. New York

Uma descrição feita dessa maneira pode ser considerada empobrecedora do raciocínio operado no projeto, mas, de toda forma, é importante para trazer para esse mapa mais um ponto que me guia nesse percurso: a incorporação de elementos externos não como condicionante formal ou em termos funcionais, mas como transformador das relações criadas no diagrama. Lidos a partir de um ponto de vista específico e incorporados dentro de um sistema, elementos como a forma do terreno perdem seus vínculos significativos habituais - a variação de topografia de um determinado sítio, a consciência geográfica do lugar, a vista para uma paisagem, etc. - para operarem dentro de um conjunto de relações a partir da indefınição de seu caráter icônico.

Assim, o resultado formal dessa interação não se dá em uma arquitetura pensada para corajosamente enfrentar a topografia, exibindo na sua viabilização como construção a vitória da batalha (um heroísmo bastante presente na história da arquitetura), mas em uma arquitetura que se faz a partir de elementos extraídos dela: as ideias de deslocamento, abertura, etc. como princípios de transformação. Estabelecido o diálogo, transformadas as relações, e incorporados os resultados, segue-se na suspensão do raciocínio diagramático. 


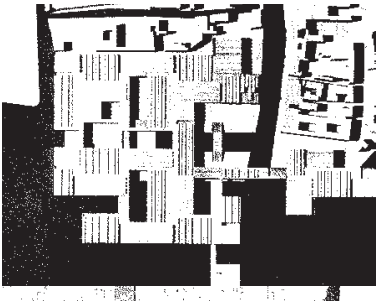

,
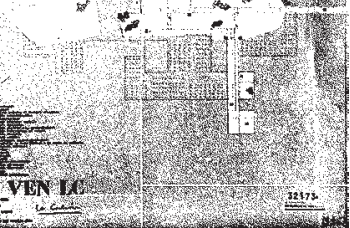

F20. Hospital em Veneza de Le

Corbusier. BOESIGER, Willy;
GIRSBERGER, Hans Le Corbusier

selected works 1910-1965.

Birkhauser, 1993.

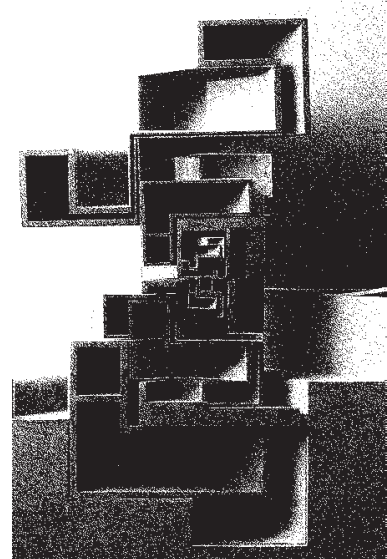

No Cannaregio, proposta para Veneza feita em um concurso internacional, Eisenman novamente promove a incorporação de elementos externos ao raciocínio forma executado no ambiente de projeto. Se no caso da House $X$ que se incorporu foram apena uma condição topográfica, elementos que, se traduzidos verbalmente, talvez ganhassem forma de verbos substantivados (um deslocar específico, o abrir de certa forma, etc.), no caso do Cannaregio, assim como em uma série de projetos feitos depois dele, foram incorporadas também as próprias formas dos elementos, tratados, entretanto de maneira descontextualizada e desvinculada de significados ligados a elas anteriormente. Assim, de um antigo projeto de Le Corbusier para a mesma cidade, um hospital implantado parcialmente sobre as águas, Eisenman extrai a forma da malha regular que o organizava e o princípio nela presente, ou seja, a arbitrariedade com que cada ponto era marcado da superfície, independentemente de ser na água ou na terra. Com essa arbitrariedade, Eisenman literalmente faz uma colagem da malha sobre o tecido milenar da cidade, com pontos ora caindo no espaço livre da praça, ora sobre antigas construções, gerando escavações que marcavam o grid. Deslocado dele, mas seguindo o mesmo princípio, traz sua House 11 a que é reproduzida e multiplicada em diversas escalas não apenas ao longo dos pontos do grid, como também dentro de cada uma delas, gerando espaços que não poderiam ser acessados e, muitas vezes, nem mesmo vistos, tendo sua existência totalmente dependente de uma dedução baseada na percepção da repetição.

F21. Seçăo de casa inabitável do

Tracing Eisenman. New York, Rizzol,

2006.

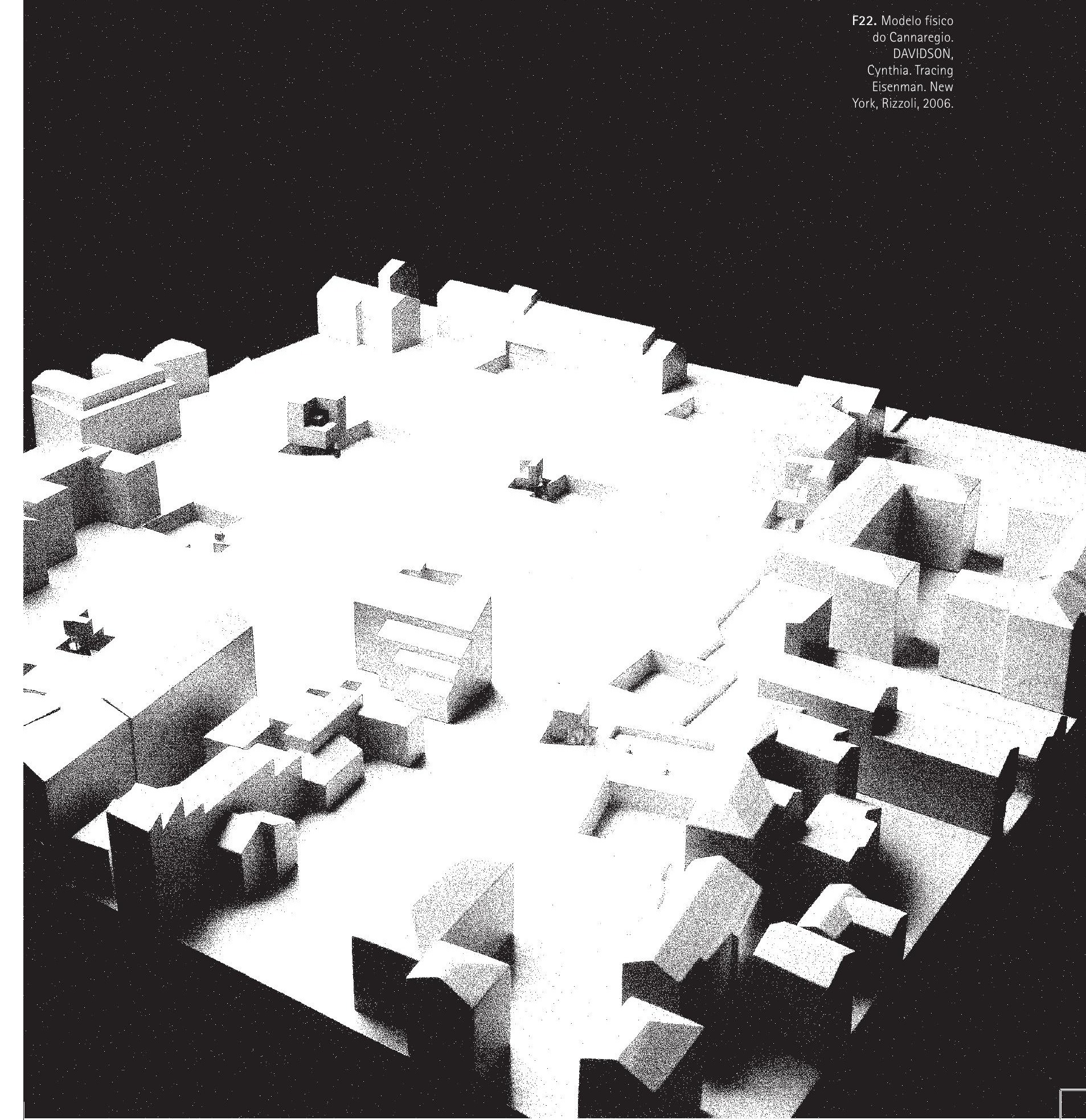


De maneira semelhante, o IBA Social Housing, projeto feito dois anos depois para uma área de Berlim próxima ao Check Point Charlie (posto militar de controle entre a Berlim ocidental e oriental), ao sobrepor em diversas alturas camadas que se constituíam como espécies de memórias físicas da cidade, transformando o terreno segundo as palavras do arquiteto, em um sítio arqueológico fictício. Muralhas e muros de diversas etapas e momentos de Berlim, malhas e sistemas cartesianos de localização são combinados em somas, subtrações e processos de extrusão, resultando em formas cuja aparente aleatoriedade é incorporada como dado a partir do qual o projeto é desenvolvido em termos construtivos e funcionais. Em 1982 Peter Eisenman submeteu seu projeto em Berlim para a apreciação de seus colegas em um evento no qual cada um dos vinte e dois arquitetos convidados deveria apresentar um projeto recente, um episódio anedótico narrado por Cynthia Davidson: “(... Eisenman mostrou seu projeto do IBA Social Housing para o Check Point Charlie, um local próximo ao Muro de Berlim e, na cidade dividida, carregado de significado. $O$ projeto era uma 'escavação artificial' inicial em que as camadas de mapeamentos - que ele chamou de superposições - conduziram a uma construção de sentido que 'deriva do seu próprio processo interno', e não do contexto ou da mão do autor. Rem Koolhaas criticou a intenção de Eisenman, argumentando que não há 'garantias de que [o IBA] será percebido como nada mais do que uma neurose pessoal'. Rafael Moneo disse: "O grid é o seu contexto artificial... sua própria sintaxe... Ele está falando uma linguagem em que palavras perderam seu sentido". Eisenman respondeu: "Se for possivel de se fazer palavras esvaziadas de sentido, eu gostaria de tentar fazer isso". ${ }^{54}$

\section{0}

$2 \operatorname{lig}^{2} 10$

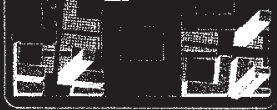

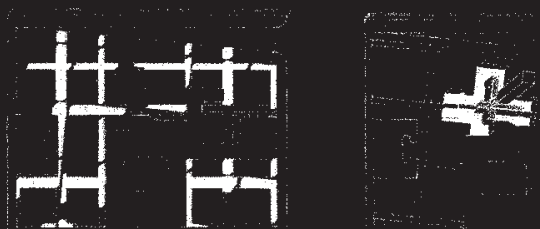

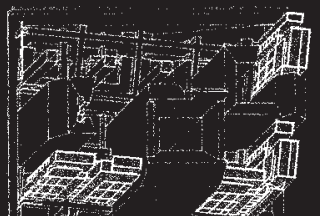
F23. Planta e foto de
rachada do

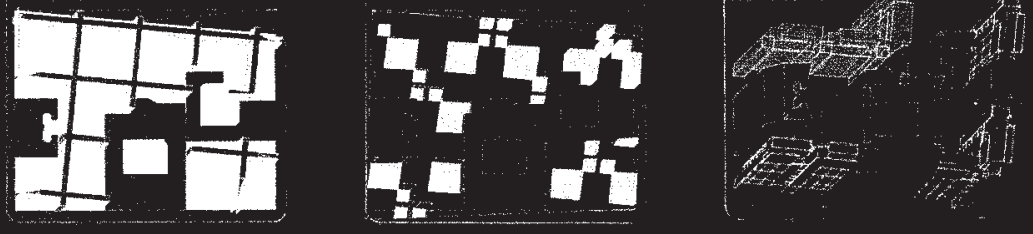

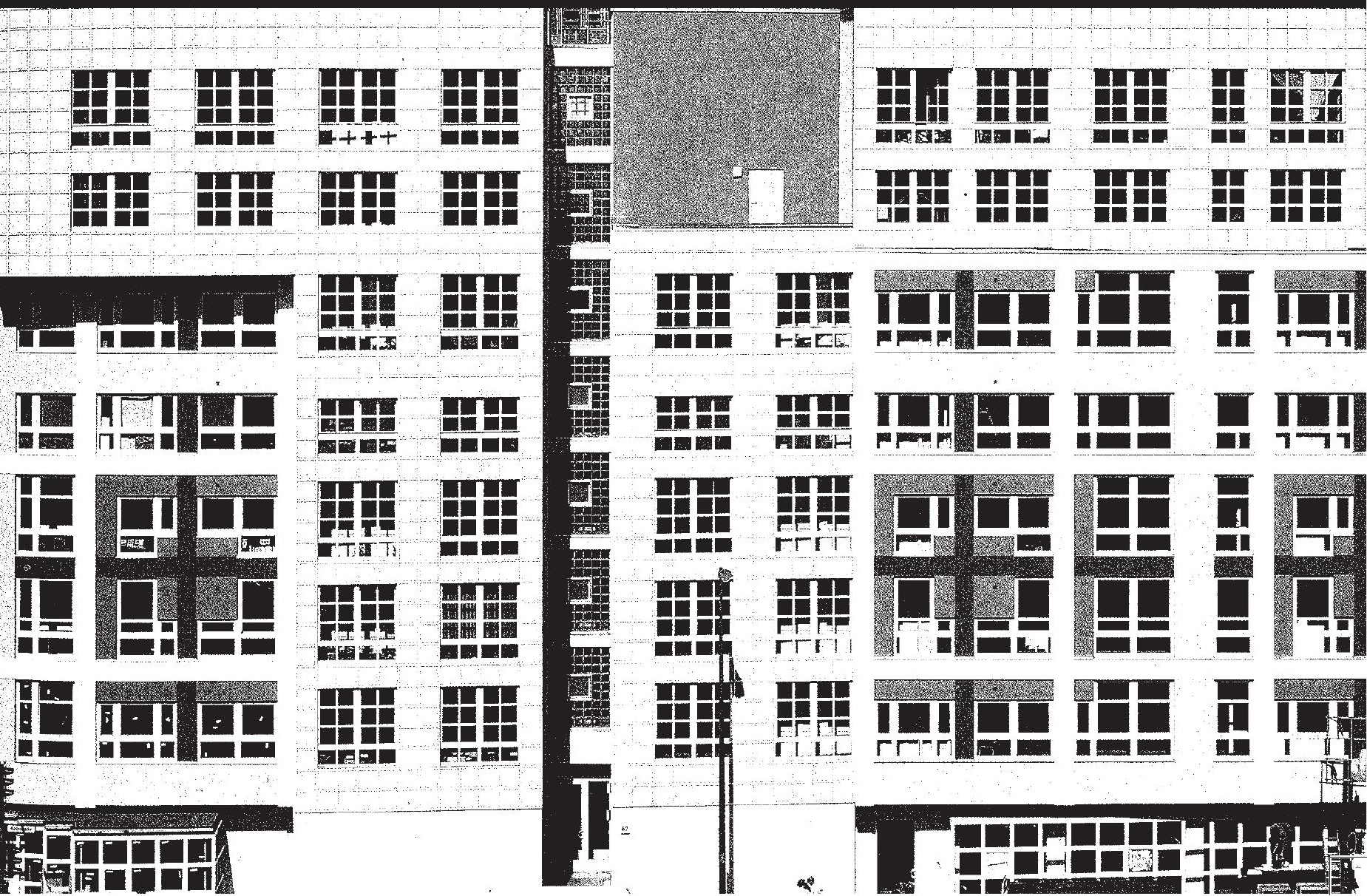




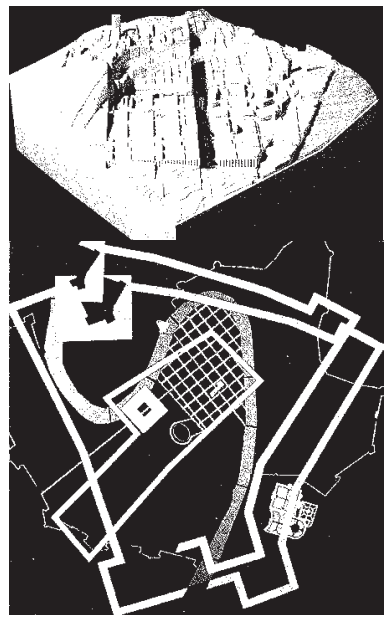

0 mesmo processo de esvaziamento de sentido e descontextualização que reduz elementos como um mapa, um projeto ou um texto a conjuntos de relações formais ou a princípios de transformação é operado em uma série de outros projetos posteriores como, por exemplo, o Moving Arrows, Eros, and other Errors ${ }^{55}$, projeto para a cidade de Verona no qual Eisenman faz uma leitura das três versões de Romeu e Julieta para construir mais um sítio de "escavação artificial", trabalhando novamente com a escala: "Através das múltiplas versões da história, a configuração é criada em mais de uma escala, prejudicando assim a obsessão antropocêntrica com a escala humana que tem dominado arquitetura desde o Renascimento"s.

F24. Modelo e diagrama de Moving
Arrows, Eros, and other Errors Arrows, Eros, and other Errors.

Eisenman. New York, Rizzoli, 2006

Uma das questões que podem ser extraídas desse tipo de abordagem projetual é relativa à visão que se tem do autor naquilo que diz respeito à intencionalidade. Condicionado por um conjunto de princípios, por um modo de representação ou até mesmo por formas e elementos determinados a priori, o trabalho e o gesto do arquiteto estariam incorporados (ou aprisionados) nessa

55.0 curioso nome dado por Eisenman a esse projeto, assim como no caso da Hous, construçōes verbais que trabaIham com a palaura escrita e falada, não apenas com o seu significicado conesvaziado, antecipa em alguma medida a natureza da exploração projetual e coloca em diálogo com algumas das pesquisas da linguística, como as de Noam Chomsky, de quem Eisenman era leitor.

56. EISENMAN, Peter; DAVIDSON, Rizzoli, 2006, p.118. Tradução nossa.

espécie de máquina de geração de formas. Entretanto, além de assumir qualquer projeto de arquitetura como algo necessariamente baseado em condições que antecedem os cálculos formais executados durante o processo condições que constituem, por exemplo, a habitabilidade da obra -, entendo que mesmo o gesto, cuja compreensão é muitas vezes coberta por uma neblina mística, não é livre de uma maneira muito específica de traduzir as formalizações realizadas mentalmente. 0 projeto de arquitetura não é a expressão de uma suposta ideia arquitetural formulada internamente (e anteriormente), mas a formalização de um processo de raciocínio operado no próprio ato de projetar, do qual fazem parte não só as capacidades perceptivas e expressivas do arquiteto, como também a natureza dos materiais com que ele trabalha.

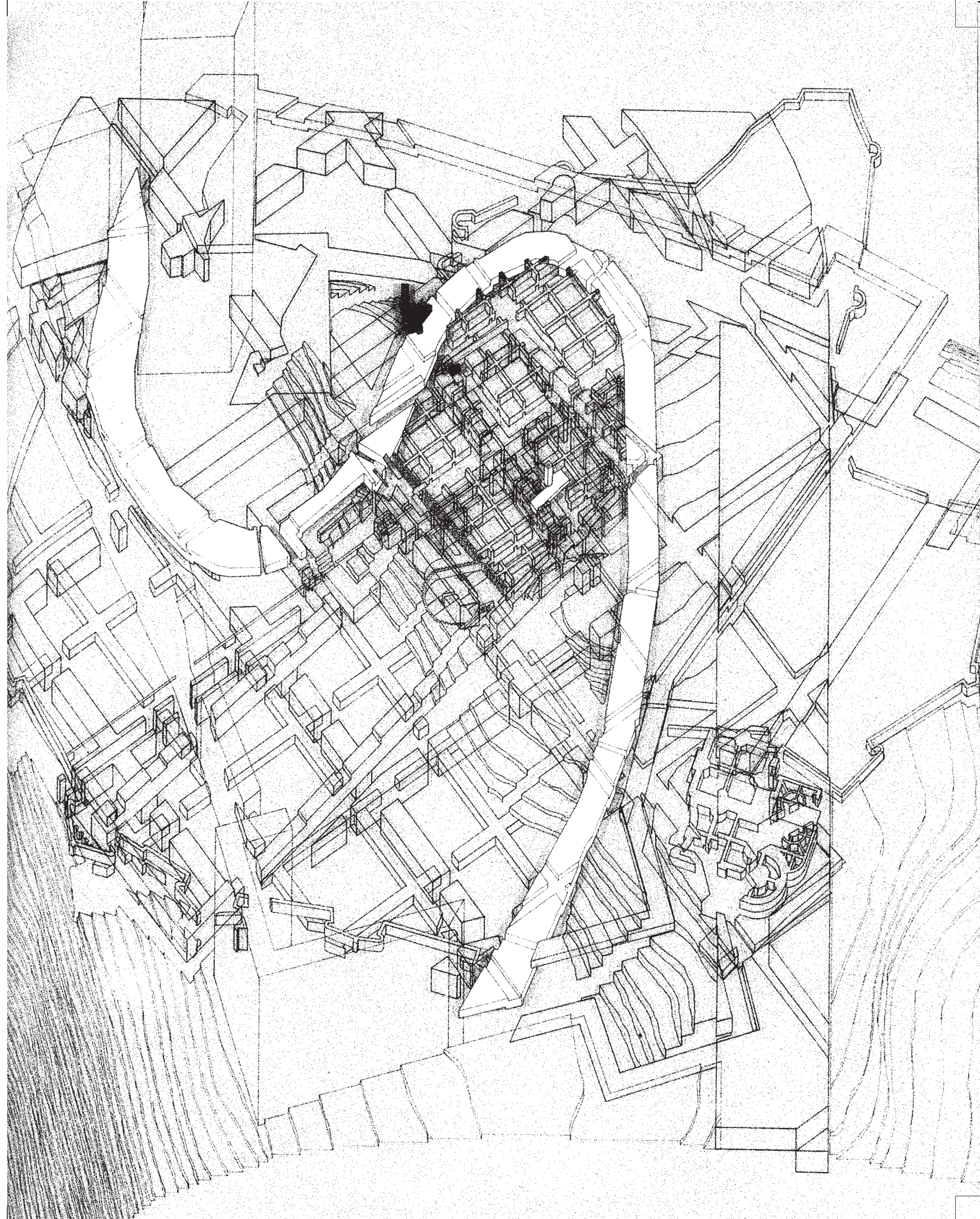


57. Greg Lynn foi integrante da equipe de Eisenman no projeto do
Biocentrum e é o curador da exposição "Archaeology of the Digital" realizada de 7 de maio a 13 de outubro de 2013 no Can
for Architecture (CCA).

58. EISENMAN, Peter. "Biology Center for the J. W. Goethe University of Frankfurt, Frankfurt fev. 1988, p.30. Tradução nossa. projeto do Biocentrum, além das condicionantes trabalho 作 p̧ỗes formais, a determinação de uma procedimentos foi levada a um nível de definição tão alto que levou a comparação com a máquina a um limite muito próximo de realização, chegando a ser descrito por Greo Lynn ${ }^{57}$, no seu esforco de escrever uma historia da chamada "arquitetura digital", como um momento de invenção da "abordagem paramétrica". Partindo de uma representação esquemática usada tradicionalmente na Biologia - na qual o DNA é descrito através de formas cores - o projeto foi desenvolvido con "uma leitura arquitetônica dos conceitos biológicos de processos de DNA", interpretando-os "em termos de processos geométricos" e "abandonando a geometria euclidiana clássica, sobre a qual a disciplina é baseada, em favor de uma geometria fractal", que estabeleceria um elemento de similaridade com a geometria dos processos do DNA e uma analogia entre a construção biológica e a construção arquitetônica. "No projeto, as figuras da Biologia foram sobrepostas sobre o terreno em uma linha com início na entrada principal, seguindo a exata sequência da cadeia de DNA para a proteina do colágeno, que produz a resistência à tração necessária em estruturas biológicas como o osso (..). o projeto foi produzido pela sujeição deste código figurativo aos próprios processos que ele descreve. Estes processos biológicos foram interpretados arquitetonicamente através da geometria fractal. Na geometria fractal, formas geométricas crescem através da aplicação de uma forma de geração em uma forma base" ${ }^{58}$.

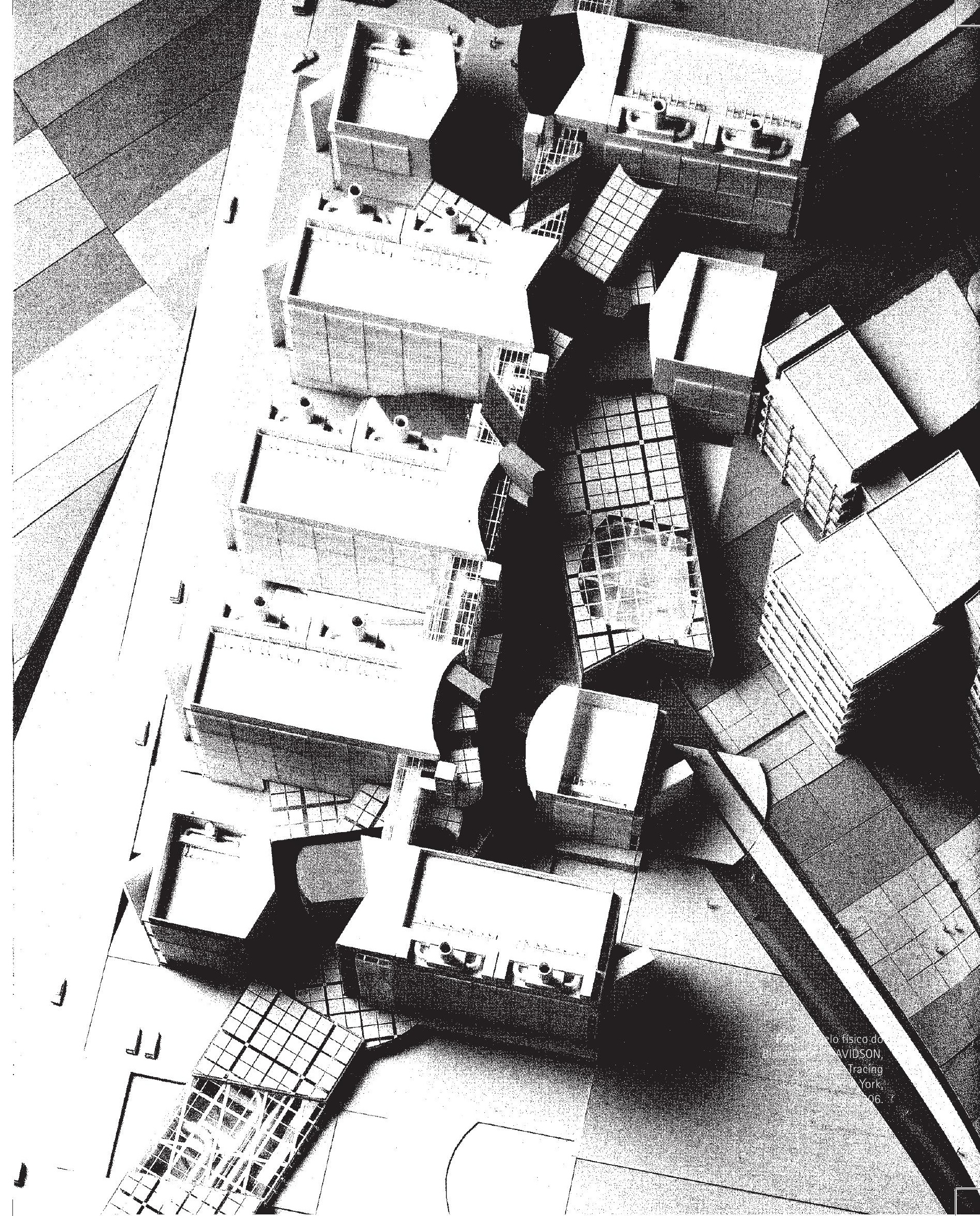


0 princípio combinatório do DNA e a geometria fractal, convertidos em conjunto de regras para o desenvolvimento do projeto, estabeleceu uma curiosa interpretação de uma das condições descritas no programa de necessidades: a possibilidade de futura expansão do complexo de edifícios. Mais do que detalhar um edifício e a sua implantação, assim como desenhar as construções e ligações que poderão ser realizadas futuramente, o projeto de Eisenman escreveu o código genético que guiará o crescimento da obra. Nesse sentido, o arquiteto perde a relação direta com o desenho, e a expressão ou gesto (em um sentido mais restritivo dos termos) deixam de se relevantes para a discussão da obra. Isso não significa, entretanto, uma falta de intencionalidade, mas apenas põe evidência uma mediação.

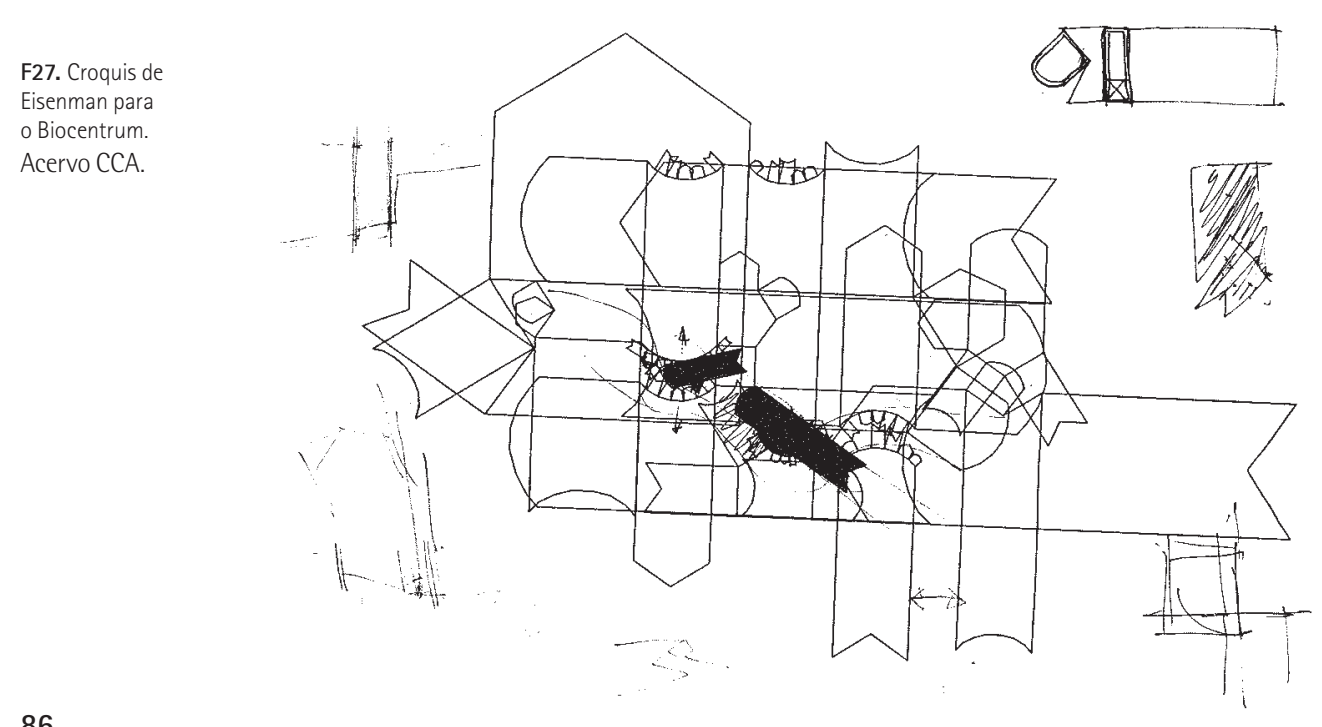

RULES $\quad 6-16-27$

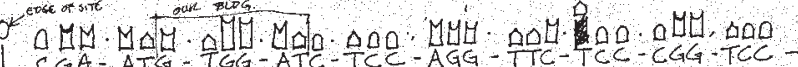

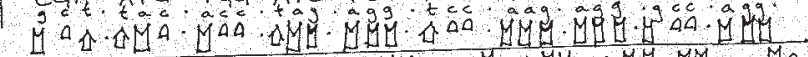
q 20 -

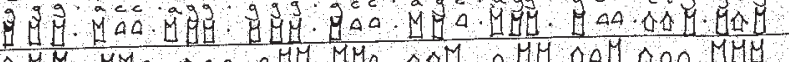

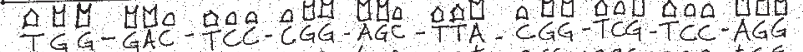

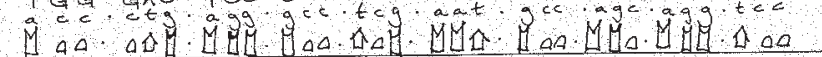

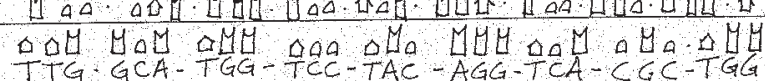

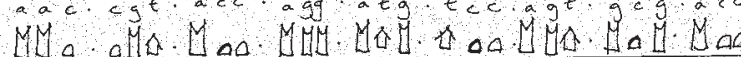

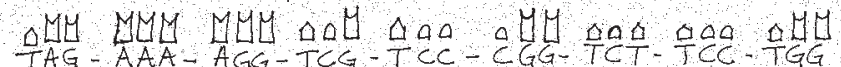
Ma

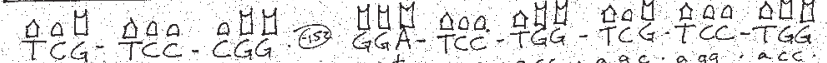

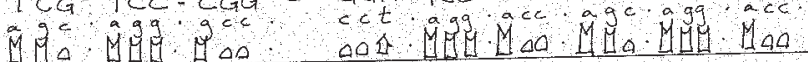

Generation 1: Base figures

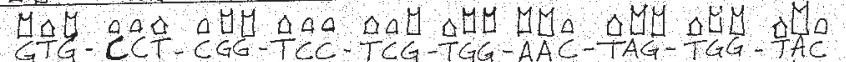

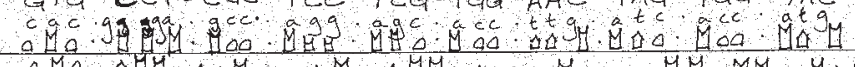

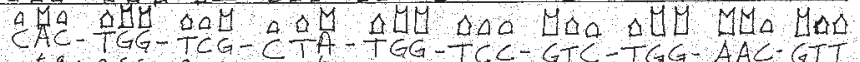
MoH. Waa MHa.

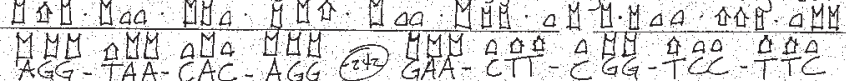

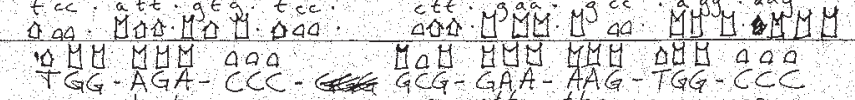

front: solid, $\quad$ talilide short=narrow up=left down=right

gaskets back/sides: .

tall=wide short=narrow

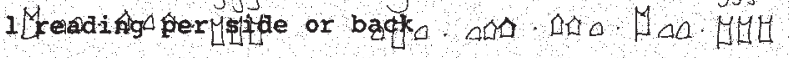

Generation 3:

front: solid (blanks become void and flip interior)

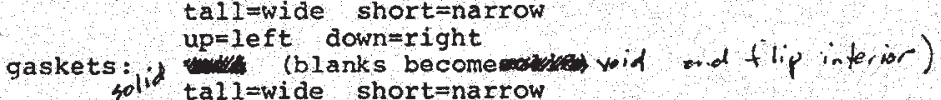

dimensions begin * below bottom surface, eat * into face

back/sides: voidenarrow shortwide 3 readings per side or back tall=narrow shortzwide 3 readings per side or back
dimensions begin * below bottom surface eat * into face

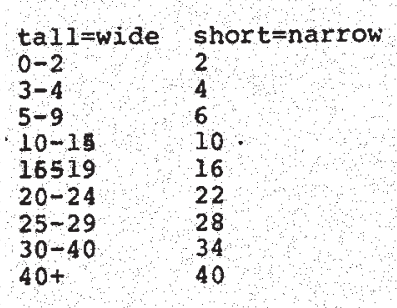

$\begin{array}{ll}\text { tallenarrow } & \text { short=wide } \\ 0-2 & 40 \\ 3-4 & 38 \\ 5-9 & 34 \\ 10-13 & 30 \\ 15-19 & 26 \\ 20-24 & 22 \\ 25-29 & 14 \\ 30-34 & 6 \\ 40+ & 2\end{array}$

$\begin{array}{ll}0-9 & 0.5 \\ 10-24 & 1.0 \\ 25+ & 1.5\end{array}$ 
Na Guardiola House, Eisenman traz novamente as formas "L" recuperando algumas questões da House X e deixando marcada na materialidade da casa a ideia de movimento. Se na Hou das sequências de quadros do cinema ${ }^{59}$ era mediado pela tridimensionalidade da perspectiva axonométrica, na Guardiola House o registro de movimento por amostragem foi feito mediado por diagramas bidimensionais cional representação corte e planta. Nessa casa a ideia se concretiza não somente no raciocínio operado através dos diagramas como também na formalização de uma estrutura flagrada em pleno movimento, estudada como as sequenciais de Eadweard Muybridge ou de Étienne-Jules Marey, retratada como na pintura cubista de Marcel Duchamp: casa descendo o morro.
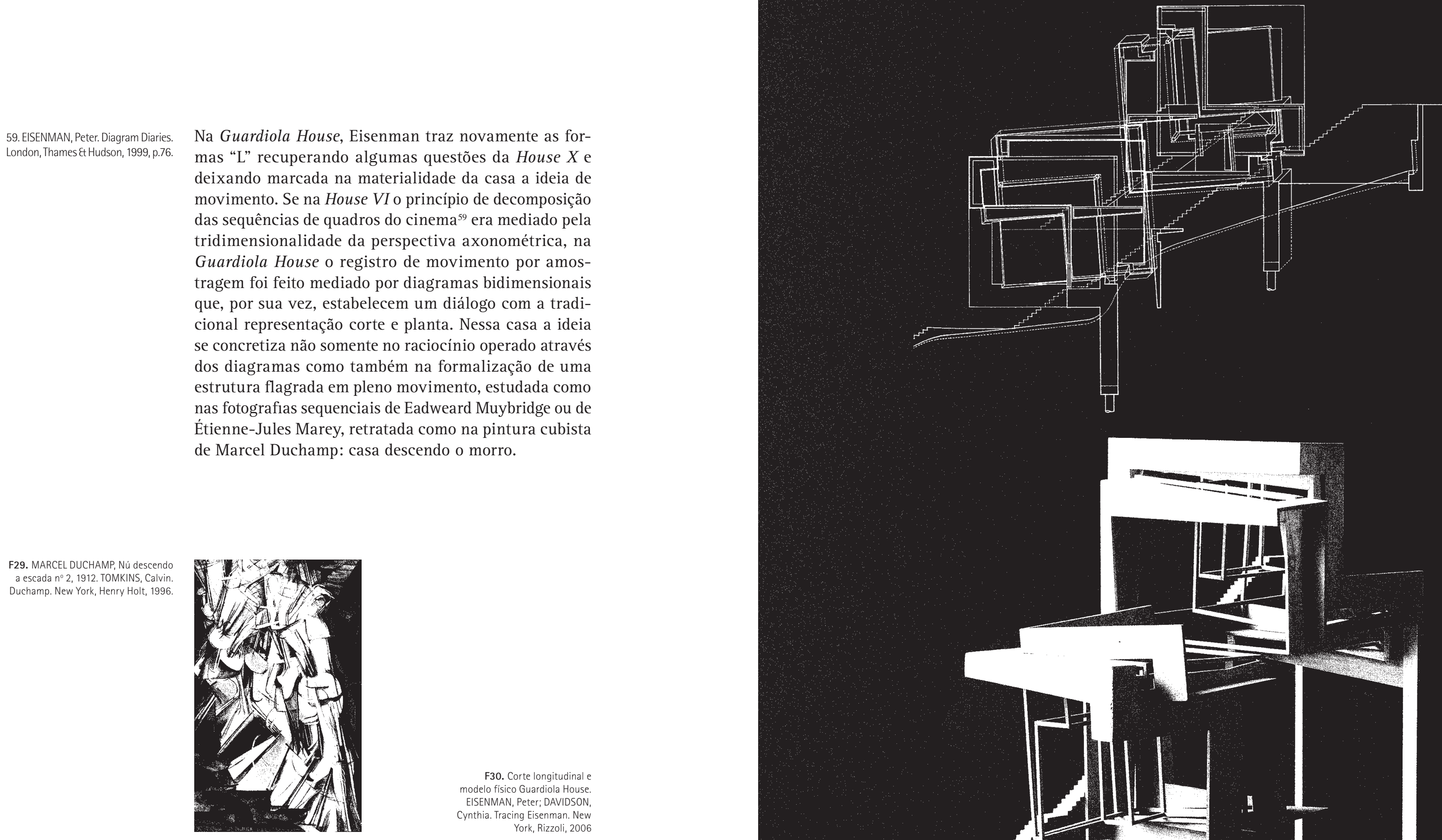
Mas nesse conjunto de retratos diacrônicos que, aqui nesse ponto onde acabo de chegar, se completa como o desenho cronológico do percurso do arquiteto (desenho feito a partir de rastros deixados pelo caminho) não encontro um método ou uma sequência de procedimentos muito bem descritos e alinhados em uma concatenação que leva inquestionavelmente à solução do problema, o projeto, mas sim um modo de pensar, de construir relações, um achado que não pode ser menosprezado pela sua falta de defınição. Nele pouco importa se aquilo com que se trabalha é o mapa de uma cidade ou a representação gráfica do DNA, uma construção existente ou um projeto não concretizado, ou ainda, o registro da fotografia, do cinema, da perspectiva axonométrica, etc. 0 que importa, e aí um traço fundamental que me ajuda a caracterizar esse tipo de processo, são os princípios extraídos de cada elemento trabalhado, incorporando aquilo que os engendram como realizações no próprio modo de se fazer e pensar uma arquitetura, no seu próprio co aponta para uma atividade de leitura das coisas do mundo, para um processo de projeto que promove conscientemente a invasão e o hibridismo, para projetos que se apresentam como traduções de um pensamento a respeito dos para um processo atento àquilo que sustenta cada realização como linguagem. 
Dos grandes saltos no tempo dados até agora, construindo (a partir da vista panorâmica proporcionada pela elevação) um relato cronológico do percurso de Eisenman, começo a transição para uma caminhada de passadas mais curtas - do comprimento de minhas próprias pernas - em paisagens das quais posso me aproximar e capturar a olho nu, para um ritmo que não é o da narrativa histórica, mas do relato pessoal, do diário. Uma escrita que não se ergue a partir de grandes acontecimentos (descritos com a criação de uma aparente continuidade ou com a demonstração de profundas rupturas), mas de pequenos detalhes capturados e pensados dentro de um conjunto de relações, que, consciente das suas próprias limitações e da impossibilidade de reconstrução dos movimentos e processos sobre os quais se debruça, empreende um esforço de criação de uma estrutura capaz de gerar movimentos análogos a eles. De un texto que figura um provável percurso do personagem, o arquiteto Eisenman, a partir de relatos e análises de terceiros, de leituras de projetos e espaços arquitetônicos mediados pelas publicações - as fotografias e textos reproduzidos em publicações impressas e eletrônicas que marcaram a primeira fase da pesquisa -, começo a transição para um texto que procura resgatar uma experiência pessoal: a confrontação com a cidade de Berlim e o Memorial dos Judeus Assassinados da Europa. A ideia de confronto não surge aqui à toa. Entre aquilo que eu conhecia a respeito da cidade e da obra, aquilo que, inevitavelmente, havia se consolidado como uma interpretação, e aquilo com que me deparei, as múltiplas sensorialidades e associações a elas feitas, operou-se uma profunda transformação, um processo de "desaprender" que, se não destruía as estruturas cristalizadas como conhecimento, ao menos as colocava em estado de suspensão. Tentando abarcar o ambiente desse confronto, mesmo com o risco de causar prejuizo à inteligibilidade desejada para um trabalho acadêmico, trago para esse texto alguns dos fragmentos dessa experiência que não deve ser entendida apenas como o conjunto de elementos que captei através das minhas capacidades perceptivas, mas do pensamento que se construiu nessa interação entre as interpretações baseadas em textos e fotografias e as baseadas na vivência do espaço. Assim, a transição feita pelo texto, com a invasão de elementos da experiência, é análoga ao processo vivido na pesquisa. 0 relato e as análises passam gradualmente a ficar submetidas a um deslocamento espacial e temporal ou, para ser mais rigoroso, à narração (ou tradução) desse deslocamento em forma de texto. 



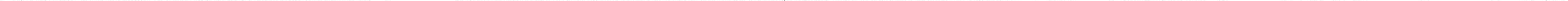


12. Les quatre cents coups ${ }^{60}$. A monumental torre se impõe à grande metrópole, revelando-se a cada espaço entre os edifícios, por de baixo de marquises, atravessando portais, onipresente na paisagem da obra-discurso-técnico do engenheiro Gustave Eiffel, glorificação da vitória do homem sobre a natureza, Babel do mundo mecânico, estrutura funcional emitindo ondas de rádio que anunciam "você está em Paris", um corte violento (suavizado apenas pelo fade-out da imagem e pela transição do tema musical que gradualmente se reduz a um delicado dedilhar de cordas) para a prosaica cena da sala de aula na qual os garotos traficam a fotografia de uma da sala de aula na qual os garotos traficam a fotografia de uma
pin-up: do espetacular ao ordinário; o pequeno e compartimentado apartamento; aquecedor a carvão, mesa para três, cômoda, janela e portas de madeira corroída pelo tempo; atravessar a rua para comprar farinha; Antoine Doinel caminhando pelas largas calçadas com seu colega; um beijo proibido junto a uma das grades que fecham as esquinas; as vidraças do comércio ao longo da rua; os dois meninos correndo pelas escadarias de Montmartre e a cidade vista do alto; mansardas. 
Les amants $d u$ Pont-Neuf ${ }^{61}$. No túnel mecanizado do metrô o som afiado do violoncelo percorre os corredores, vem de longe e corta a passividade com que ela era levada: quer encontrá-lo, mas onde? Não nesse corredor... Nem nesse... Segue desesperadamente pelo do meio acompanhado intermináveis painéis publicitários. 0 som é interrompido e ela se vê em uma encruzilhada. Novos acordes e a perseguição recomeça. Lances de escada, outros cruzamentos, derivações, cordas agudas freneticamente arranhadas, vão arrebentar, um labirinto... onde?; nas obras de restauro da Pont-Neuf, no coração interditado da cidade, os dois sem-teto e mais o velho vivem. Uma unidade de vizinhança de três pessoas: remansos da ponte como quartos, atravessar a rua para falar com o vizinho, apagar a luz do poste para dorr. "a cidade é uma casa. a casa é uma cidade" s-espetáculo construções ordinárias, reformas urbanas demolidoras e singelos cafés de esquina, a monumentalização da história e a vida diária sem glórias ou sentido: diversas faces daquela cidade retratadas a partir dos mais variados pontos de vista, dando ao espaço da cidade mais do que o status de cenário para dramas e comédias, mas de personagem vivo e em pleno ato.

61. OS AMANTES da Pont-Neuf. Direção: Leos Carax. Fotografia: Jean-Yves Escoffier. Música: Arvo Pärt, Frederic Chichin, David Bowie. [Paris] . Films Christian Fechner - FLLMSA2, 1991. 1 DVD (125 min.) color. Titulo original: Les amants du Pont-Neuf.

62. ARTIGAS, João Batista Vilanova. "Arquitetura e construção". In: Caminhos da arquitetura. São Paulo, Cosac Naify, 2004, p.119 
Mas, ao contrário de Paris, cuja da guerra, a uma escrita que não

silhueta eu julgava ser capaz procurava falar da cidade, mas de de adivinhar antes mesmo de eventos diacronicamente encadeconhecê-la (uma falsa e relativa ados de um fenômeno já extinto intimidade criada pela infinidade tendo-a apenas como pano de de imagens, sons e movimentos fundo: Berlim não é a cidade, do cinema, assim como pelos mas o centro do poder nazista. estudos, pelas realizações da lite- Confundem-se nesse imaginário ratura, das artes plásticas, etc), e as cidades alemãs e as imagens de onde parti para o meu destino publicitárias de Leni Riefenstahl fınal, Berlim para mim ainda é em Triumph des Willens ${ }^{63}$, os um mistério. Descrita em textos gigantescos desfiles militares, guiados pelo modo de olhar da a infınidade de pessoas desproHistória, a vida de seus espaços vidas de identidade, de corpos estava submetida à narração do formando volumes geométricos terrivel fenômeno do nazismo e alinhados em grandes avenidas, ruas e quarteirões, formando uma malha urbana viva, imagens não menos fantásticas que as de Metropolis $^{64}$ (que, não à toa, Hitler ${ }^{65}$ ): a forma da cidade nazista não é apenas a de Berlim ou de Munique, mas também a da multidão organizada no Zeppelinfeld, e às ruas de Nuremberg pertence o rio de soldados marchando em incrivel sincronia.

63. 0 TRIUNFO da vontade. Direcão: Len Riefenstahl. Alemanha: Leni RiefenstahlProduktion [produção]: NSDAP - Reichsleitung [produção], 1934 Bloomington: Synapse Film

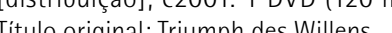

64. METRÓPOLIS. Direção: Fritz Lang. Alemanha: Universum Film Aktiengesell [produção], 1926 São Paulo: Continental Home petb. Titulo original: Metropolis.

65. Segundo Kracauer, reproduzindo as palavras de Fritz lang, o cineasta se encontrou com Goebbels e recebeu através dele um convite feito por Hitler para produzir filmes nazistas. 0 convite teria sido motivado pela impressão que "Metropolis causou em Hitlere Goebeels algun to Hitler. Princeton, Princeton University Press, 1947, . 165 Apud HUYSSEN, Andreas "The Vam and the Machine: Technology and Sexuality in Fritz Lang's Metropolis". In: New German Critique, n.24-25, pp.221-237.

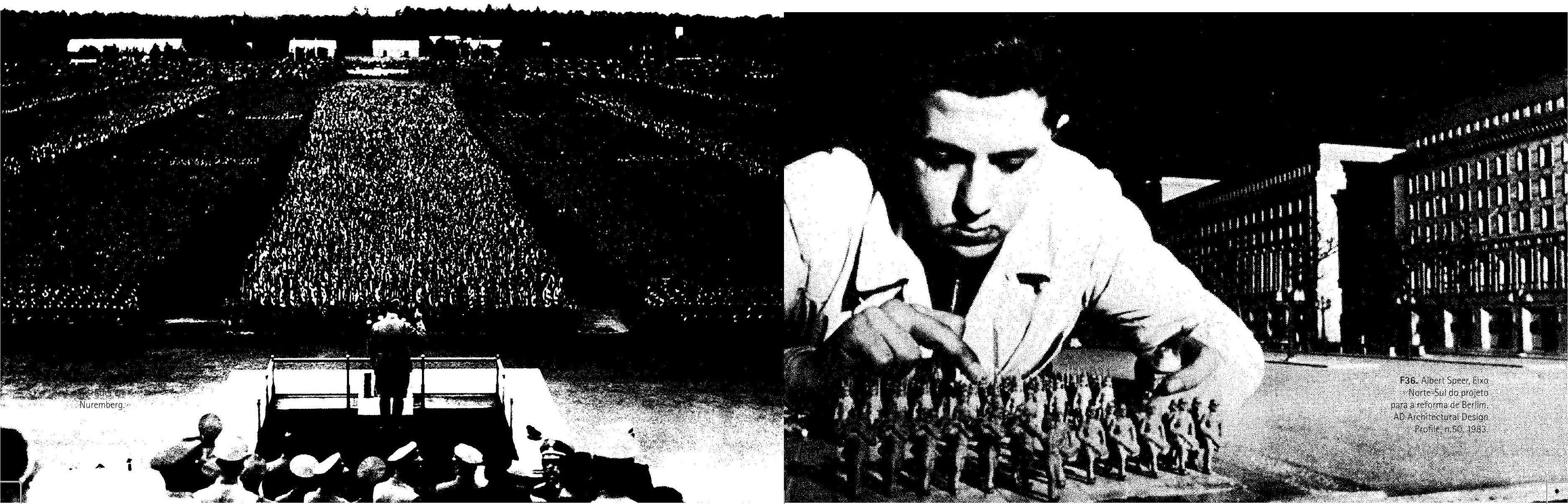


Berlin:Die Sinfonie der Großstadta

66. BERLIM, sinfonia da metrópole. Direção: 67. RICHARD, Lionel. "Uma identidade contraWalther Ruttmann. Alemanha: Fox-Europa Film ditória". In: Berlim, 1919-1933: a encarnação [produçäo], 1927 s.l.: Continental Home Video extrema da modernidade. Rio de Janeiro, Jorge [distribuiçäa], 200.100 Zahar, 1993, p.19.

A eficiente e agitada metrópole industrial do multidão cercando começo do século com seu impressionante dois homens que se exército de máquinas, máquinas de limpar batem na esquina, as ruas, de fabricar as lâmpadas, forjar vi- um guarda no crugas, polir panelas, cavar túneis, transportar zamento heroicapessoas, lavar pratos, de vender inutilida- mente organizando des nas intermináveis vitrines alinhadas ao os fluxos, pessoas, longo das ruas, como se fossem igualmente máquinas e animais fabricadas em série, com o mar de pesso- por todos os lados, as, bondes, carros e carruagens, bicicletas mais de quatro micruzando freneticamente as ruas e calçadas, lhões de habitantes, esbarrando uns nos outros, um cavalo caído não sobra ali qualem um acidente de trânsito, uma pequena quer espaço vazio,

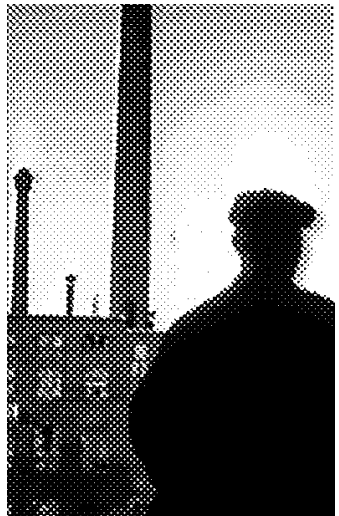

com sua intensa vida noturna, suas cervejarias servindo mais de duas mil pessoas por noite ${ }^{67}$, suas casas de espetáculos dos mais diversos tipos, um mágico, um cavalo, mulheres seminuas dançando em roda, do teatro de Erwin Piscator e Bertolt Brecht, dos trezentos cinemas, de Schönberg, do Dadá, das casas de baile onde se dança o charleston, como em Paris ou como na América, com as pernas de fora, os cabelos à garconne, uma metrópole cosmopolita e transbordando vida.

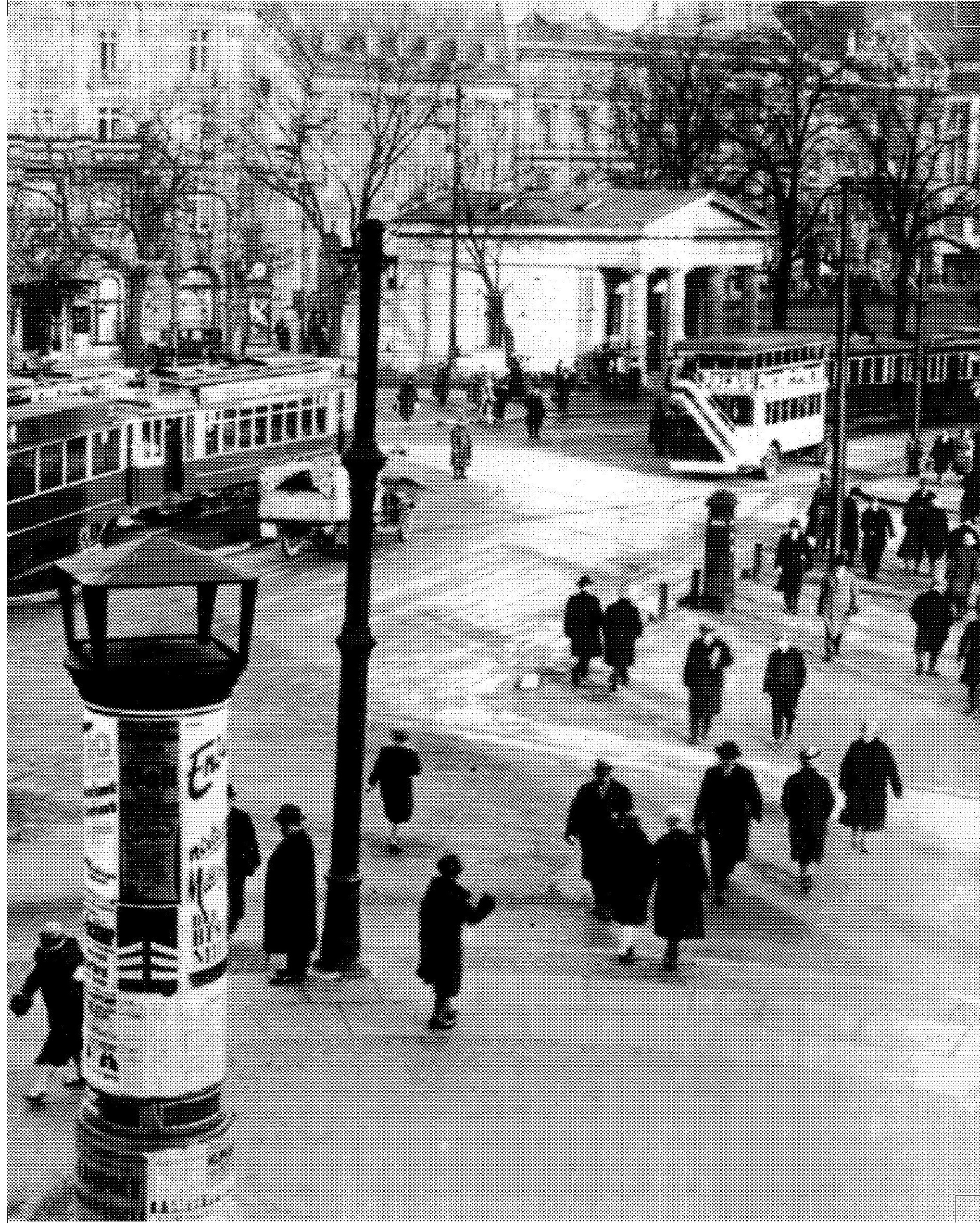




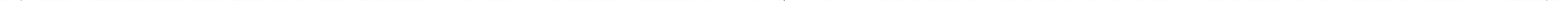


Berlin Alexanderplatz ${ }^{68}$. A Berlim do delinquente Franz Biberkopf "Estremeceu, engoliu em seco. Tropeçou no próprio pé. Então tomou impulso e sentou-se no bonde elétrico. No meio das pessoas. Adiante.

(...) Voltou a cabeça na direção do muro vermelho, mas o bonde disparou com ele sobre os trilhos, então só sua cabeça continuou virada para o lado da prisão. O vagão fez uma curva, árvores e casas intercalavam-se. Ruas animadas surgiam, a Seestraße, pessoa subiam e desciam. Dentro dele, o grito soava terrivel: atenção, atenção, vai começar. A ponta de seu nariz gelou, sua bochecha vibrava. 'Jornal vespertino do meio-dia', 'B. Z.', 'A mais nova revista', ' a Funkstunde', 'subiu mais alguém?'. Os policiais agora usam uniformes azuis. Desceu do vagão sem que ninguém percebesse, estava no meio das pessoas. E daí? Nada. (...) Formigueiro, que formigueiro Como tudo se movimentava. (...) O que era tudo isso? Lojas de calçados, lojas de chapéus, lâmpadas, lojas de bebidas destiladas. As pessoas precisam de sapatos se andam tanto de um lado para outro, nós também tínhamos uma sapataria, vamos manter isso em mente. Cem vidraças luzidias, deixe que brilhem, elas não vão amedrontar você, pode então quebra-las, o que há com elas, é que foram polidas. Quebravam o calçamento da Rosenthaler Platz, caminhou entre os outros sobre pranchas de madeira. A gente se mistura aos outros, a tudo passa, dai você não percebe nada, cara. Manequins posavam nas vitrines com ternos, casacos, saias, meias e sapatos. Do lado de fora, tudo se movimentava, mas - lá atrás - não havia nada! Nada parecia ter vida! Tinham rostos alegres, riam, aguardavam na ilha, diante do Aschinger, em dois, ou em três, fumavam cigarros, folheavam jornais. Ficavam como postes - e - cada vez mais imóveis. Faziam par com as casas, tudo branco, tudo madeira".

68. DÖBLIN, Alfred. Berlin Alexanderplatz. São Paulo, Martins Fontes, 2009, p.13.

69. HESSEL, Franz. Promenades dans Berlin. Paris, L'herne, 2012.

70. Localidade ao sudeste de Berlim, às margens de um lago do Rio Havel, do qual o Spee é afluente. 71. Antiga patisserie berlinense.
Promenades dans Berlin ${ }^{69}$.A Berlim do flâneur Franz Hessel."Pelo passeio que leva à estação atravessam transeuntes em saias claras e roupas de tecido lavável. Estes afortunados! É um belo dia de outono! Alguns escolhem a passarela estreita que leva à pequena estação de Wannsee ${ }^{70}$. Gostaria de ir atrás deles. Um veleiro ou ao menos uma canoa! Ou apenas um pequeno passeio em um dos Parques de Potsdam. Potsdam e os lagos do Havel, a alma secreta, a terra além de Berlim. E hoje, além disso, é dia de semana. Mas agora nós chegamos na Potsdamer Platz. É preciso dizer, de antemão, que não é uma praça, mas o que chamamos, em Paris, de carrefour, ou seja, um cruzamento, uma encruzilhada de ruas. Nós não temos uma palavra exata para isso. Outrora havia neste lugar uma das portas da cidade, onde Berlim acabava e de onde partiam as grandes estradas; seria necessário um olho particularmente bem treinado para, no mapa, achá-la na forma do carrefour. O tráfego é aqui oficialmente tão denso, em um espaço relativamente acanhado, que frequentemente nos espantamos de vê-lo tão fluido e tranquilo. $O$ efeito calmante decorre também das numerosas cestas multicoloridas e transbordantes dos comerciantes de flor. No meio, se destaca a famosa torre de sinalização que regula os jogos das ruas, tal como uma cadeira de árbitro de um jogo de tênis. Em pleno meio dia, as mensagens e imagens gigantes dos anúncios publicitários sobre os muros das casas e dos telhados, tem agora um ar estranhamento adormecido e vazio, elas esperam a noite para despertar. Clara, suave, à moda da "jovem Berlim", a renovada casa que abriga a antiga e famosa Conditorei Telschow ${ }^{71}$, desenha as suas linhas de vidro. Ainda por hora, o Josty-Eck resta daquele tempo antigo. Mas, do outro lado da Schöneberger Straße, ainda parcialmente escondido por um alto muro coberto de andaimes, um grande magazine com nome francês se ergue. Será ele tão belo como a obra prima de Messel, lá de trás da folhagem da praça de Leipzig : o edifício de Wertheim? A Schöneberger Straße, sobre a qual podemos lançar um breve olhar, se torna cada vez mais a rua "La Boétie" de Berlim. Lojas de arte se agrupam a outras lojas de arte. E, entre elas, as vitrines dos magazines de moda se tornam cada vez mais refinadas, com uma tendência crescente à natureza morta". 
0 que restou daquela cidade vibrante? 0 que restou de qualquer outra cidade que Berlim pode ter sido? 
Germania anno zero ${ }^{72}$.

Da larga pedra do meio-

fio a câmera se levanta, acompanha-

da no movimento pelo vigor dos sopros na

trilha, para impiedosamente anunciar

a tragédia: os edifícios desfigurados, as

ruas tomadas por entulhos, paredes sol-

tas no espaço prestes a tombar, bastando

para isso uma simples rajada de vento.

Sobre um carro ela percorre as ruas miran-

do as ruínas, reproduzindo os olhos de um turista em um city tour. Já

se passaram dois anos dos fatídicos acontecimentos e Rossellini quer de-

nunciar as condições de vida de três milhões e meio de pessoas de Berlim.

“(...) vivem uma vida terrivel, uma vida de desespero, quase sem nem se darem conta. Elas vivem como se a tragédia fosse um elemento natural,

mas não por serem fortes ou por terem fé, mas por estarem cansadas".

Inspecionados por um distinto homem vestindo terno e gravata, mulheres idosas, um homem e um garoto trabalham abrindo e fechando covas em troca de comida. Um cavalo caído no chão, talvez por um acidente, tem seu destino discutido por uma pequena multidão que em volta dele se aglomera. Dessa vez, diferentemente de anos atrás ${ }^{73}$, não é levantado, mas cortado com uma faca de cozinha. Edmund Koeler, um menin de 12 anos, comtado com curtas e suspensório perambula pelas ruas desviando anos, camisa, calças levar alguma coisa para casa. Ele tenta vender a dois soldados americanos o disco com um discurso do Führer. A voz furiosa de Hitler reverbera nas pared da Chancelaria, atravessa as janelas destrocadas e alcancra reverbera nas paredes velho como uma atravessa as janelas destroçadas e alcança os ouvidos de um velho como uma assombração. O pai de Edmund está muito doente e, como rezava a propaganda do regime, é considerado um fardo pesado para todas as outras pessoas. 0 irmão mais velho não trabalha e não pegou o cartão de alimentação. Vive escondido com medo de ser preso, pois lutou nas ruas até o último minuto. Sua família divide o espaço com outras 4 nas ruas apartamento de um prédio parcialmente destruído na Alexanderplatz. Ele mora muito perto de onde eu vou ficar, mas é quase impossível distingui essa rua de qualquer outra da cidade. Procuro nas imagens algum ponto de referência, mas só vejo as formas tortas dos edifícios bombardeados que poderiam ser de qualquer outro lugar. adolescência e, ao visitar novamente a cidade, não encontrou o lugar de suas lembranças. "Quando lá voltei, parei do lado de fora do que teria sido a casa em que todos morávamos, na

Aschaffenburgerstraße, em Wilmersdorf

No mapa, a rua ainda ia da Prager Platz à Bayrischer Platz. A Barbarossastraße deveria sair justamente do lado oposto da porta da frente de nosso edifício, levando diretamente à escola de minha irmã. Mas nada disso restara. Havia casas. mas não as reconheci. Como num desses pesadelo de desorientação e deslocamento, não apenas eu ja não conseguia identificar coisa alguma no lugar como tampouco sabia em que direc̃a no orientar. 0 prédio em ruínas de minha antiga escola ainda existia fisicamente de minha antiga escola ainda existia fisicamente na Grunewaldstraße, mas a escola não havia sobrevivido à guerra. O lugar onde ficava o escritório de meu tio no centro da cidade não era nem sequer identificável no mapa, pois toda a área em vol ta da Liepziger e Potzsdamer Platz, uma terra de ninguém bombardeada entre o Leste e o Oeste, não havia sido objeto de qualquer restauraçãoste e o Oeste, não havia sido objeto de qualquer restauração desde o fim do conflito. Em Berlim o passado físico fora apagado pelas bombas da Segunda Guerra Mundial. (...) Assim, a cidade em que passei os dois anos mais decisivos de minha vida existe somente em memória" Rossellini. Itália : Teverfilm [produçăa: Union Generrale [producão] : Sadfi [produção], 1930 São Paulo: Versátil Home Video [distribuição], p\&tb. Titulo original:

3. Em uma cena semelhante de Berlin: Die Sinfonie der Großstad configurando, possive-

HOBSBAwN, Eric J. 74. HOBSBAWN, Eric J uma vida no século XX. São Paulo, Companh das Letras, 200, p.60. 
16.

E como eu poderia ter uma ideia

mais formalizada de Berlim, assim

como tinha de Paris antes de conhecê-la?

Não são apenas os desfiles monumentais e

as bandeiras vermelhas que se sobrepõe à pai-

sagem que tento desenhar em uma dedução,

mas também a consciência da enorme des-

truição, de que as ruas, edifícios e pessoas da

lente de Walther Ruttmann, dos desenhos de Georg Grosz

ou do flâner de Franz Hessel não são mais os espaços e os

habitantes daquela cidade, que desapareceram, seja pela ação do tempo, seja pelo céu de bombas de setenta mil toneladas ${ }^{75}$ que sobre eles desabou. A paisagem mais uma vez desmorona no meu desenho e toda tentativa de reconstrução inevitavelmente me leva de volta ao mar de ruínas de Rossellini, às ruas quase indistinguiveis tomadas por escombros, às filas de mulheres e crianças passando baldes de mão em mão, removendo os setenta e cinco milhões de metros cúbicos de entulho ${ }^{76}$. As ruínas não são apenas o símbolo da derrota do nazismo ou do drama vivido pelos berlinenses, não são apenas o índice da ação destruidora das bombas e tiros de canhão, mas também forma, espaço, experiência estética. Realizadas, passaram a fazer parte da cidade e de seus habitantes.

identidade contranel. "Uma Berlim, 1919-1933:aenatoria". In: extrema da modernidade Raçà eneiro, Jorge Zahar, 1993, p. 29. 76. RICHARD, Lionel. "Uma iden1919-1933: a encarnara Berlim, trema da modernidaração exlaneiro, Jorge Zahar, 1993. . Rio de.
Der Himmel über Berlin ${ }^{77}$. 0 anjo caminha com o

velho pela paisagem devastada, ouvindo seus pensamentos entre o serpentear do muro repleto de pichações (e, portanto, estamos em Berlim Ocidental) e a pesada passarela metálica que parece levar a lugar algum. "Não consigo encontrar a Potsdamer Platz. Será aqui? Não pode ser. Era na Potsdamer Platz que estava o Café Josti. À tarde eu ia lá conversar, beber um café e observava o público depois de fumar um charuto na 'Loese\&tWolf', uma tabacaria de renome, aqui mesmo em frente. Isto aqui não pode ser a Potsdamer Platz. Não se encontra ninguém a quem se possa perguntar". Ele caminha na nossa direção com alguma dificuldade, amparado pelo anjo e por seu guardachuva. Um close-up, e podemos ver novamente de perto: o seu rosto marcado pelo tempo e as ruínas dos edifícios bombardeados. Passam lentamente à nossa frente. "Era uma praça cheia de vida. Elétricos, ônibus com cavalos e dois carros. 0 meu e o do negociante de chocolates”. Ele balança a cabeça lamentando-se. No contraluz, no alto-contraste entre a vida interior do velho e paisagem morta da cidade, os dois caminham desviando de poças imundas e restos irreconhecíveis de construções. "Os armazéns Wertheim também eram aqui. Depois, de repente, apareceram bandeiras. Ali. A praça inteira estava cheia delas. As pessoas deixaram de ser amáveis e a polícia também. Não desisto enquanto não encontrar a Potsdamer Platz". Mas cansado, o velho desaba sobre uma poltrona abandonada no meio da relva, tira o chapéu e olha resignado para o vazio. "Onde estão os meus heróis? Onde estais, meus filhos? Onde estão os meus, os simples de espirito, os primitivos?". 



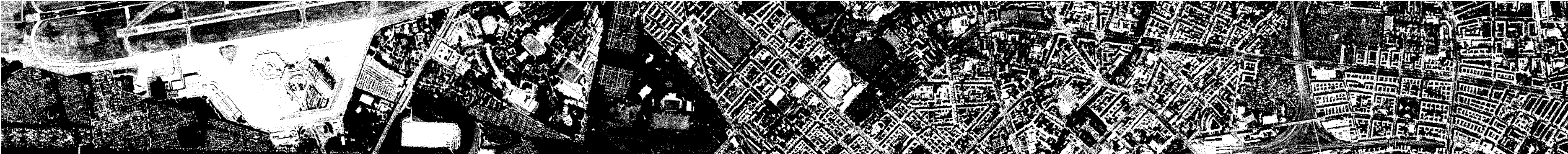

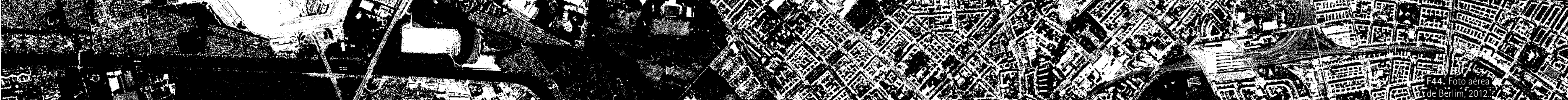
15...

1)

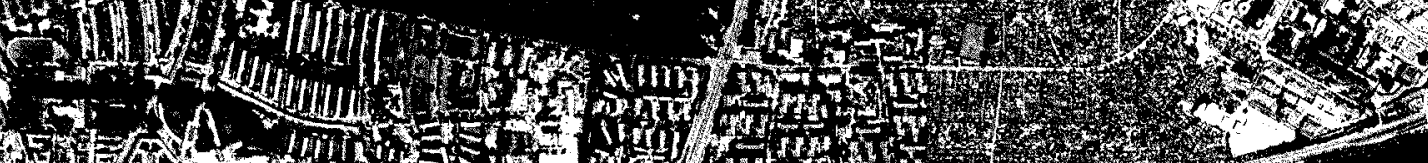
(t)

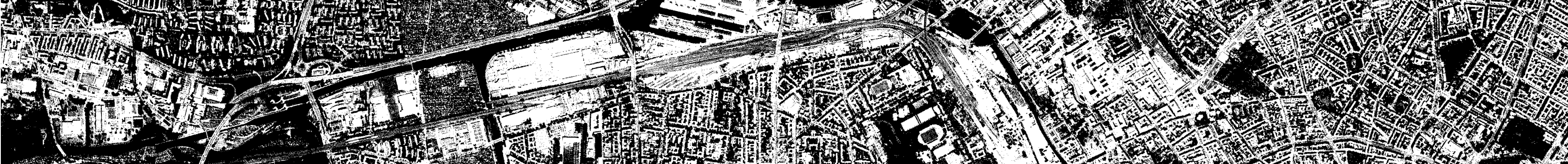

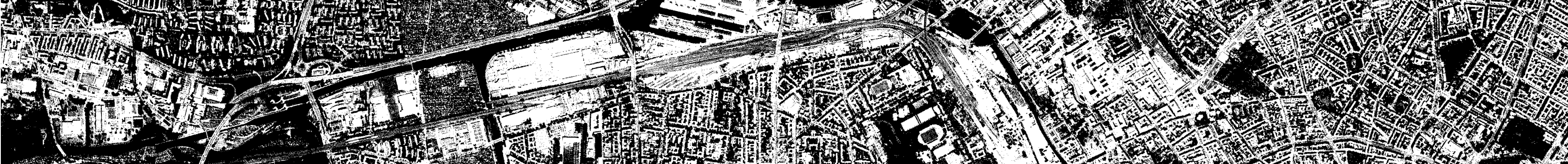
5.

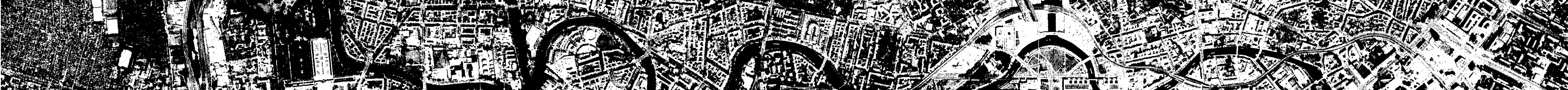

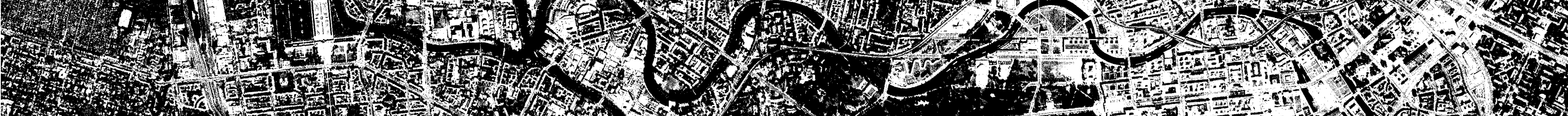
4.7. 3.7.7.

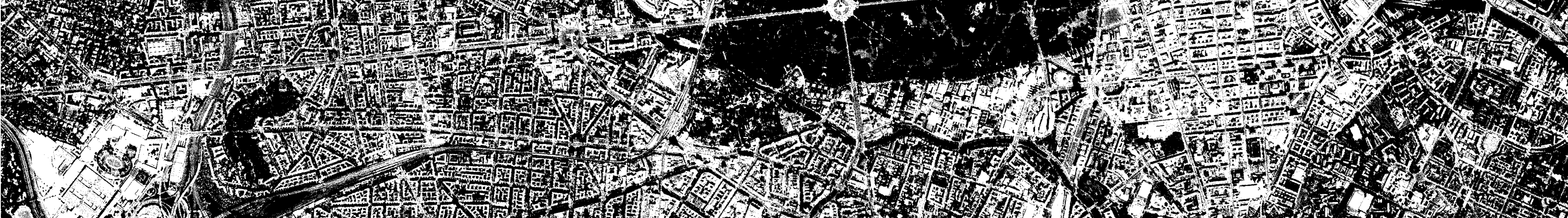
3
-1

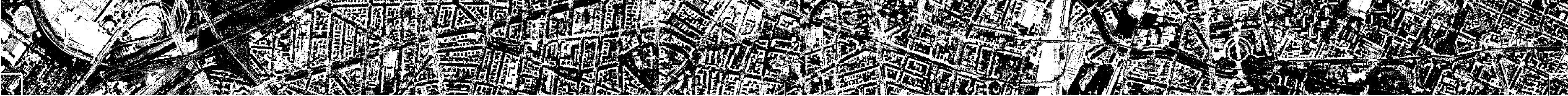



18. Nos guias e cartões postais, onde aparece ao lado da Fernsehturm, a extravagante torre de TV, e da Siegessäule, a coluna comemorativa das vitórias bélicas da Prússia, o Brandenburger Tor anuncia a entrada da cidade. Não será ele, entretanto, que eu verei ao chegar, já que ele está bem no meio da cidade, resquício de uma rápida expansão territorial feita, sobretudo, com a anexação de localidades vizinhas como Chalottenburg, Lichtenberg, Neukölln, Schöneberg, Spandau e Wilmersdorf, e que transformou Berlim nessa cidade esparramada. Ônibus; TXL; Direção: S+U Alexanderplatz; Partida: 12:16h Chegada: 12:38h. Deixando o espaço sem caráter do aeroporto. Estamos bem perto dos muros do velho presídio de Tegel onde Franz Biberkopf passou alguns anos depois de matar a sua esposa ${ }^{78}$, um dos muitos presídios que mais tarde ficaram superlotados com tantas prisões e que só foram aliviados com os campos de concentração.

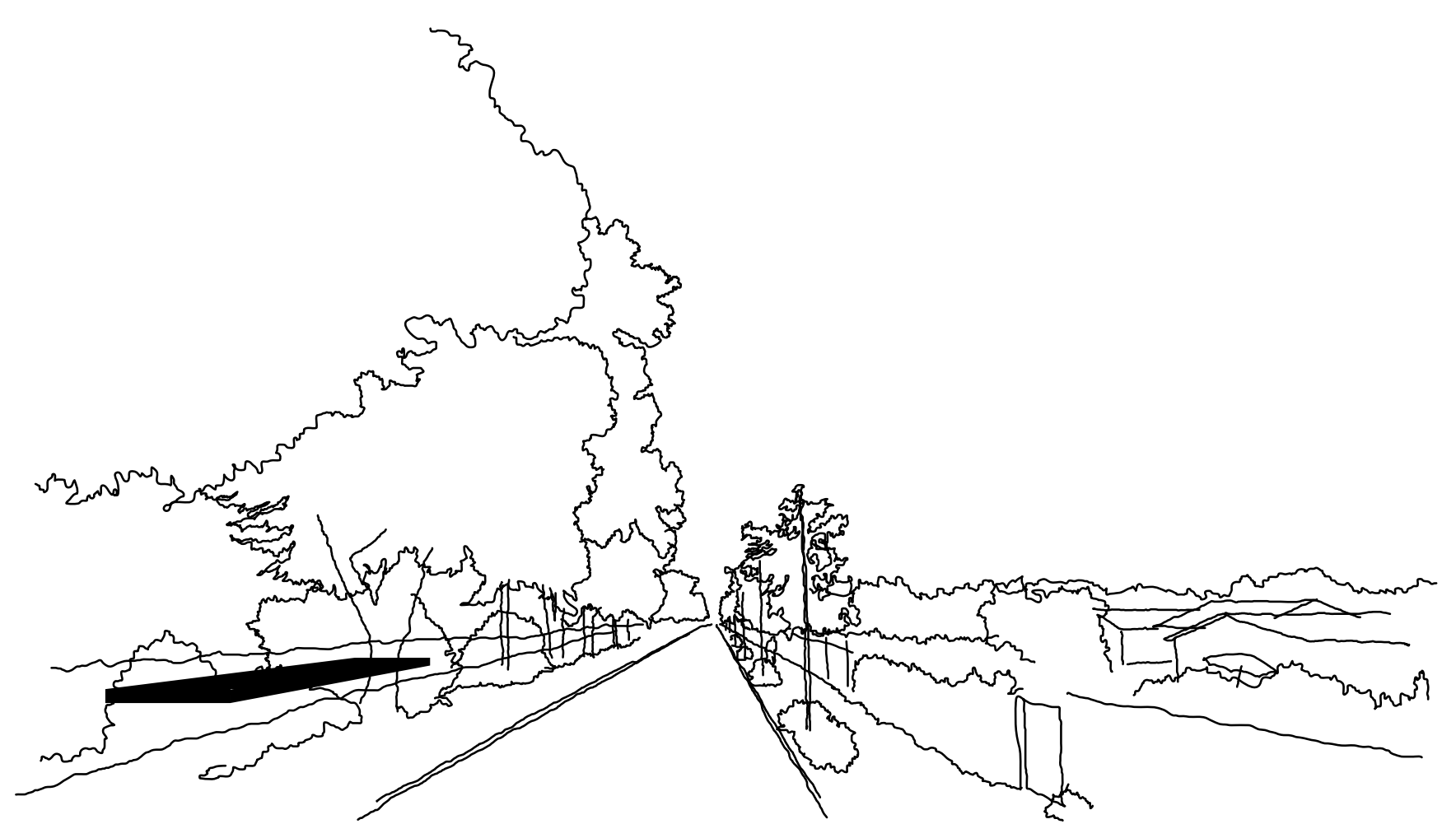

Túnel, avenida, ponte e a primeira visão de um dos canais que cortam Berlim formando o incrivel sistema de transporte hídrico dessa cidade-porto-fluvial ${ }^{79}$. Avenida, ponte, túnel. Seguindo entre o canal e um bosque, surge um bairro com cara de subúrbio: casas cercadas de jardins, espaços comerciais com grandes estacionamentos lotados de automóveis, terrenos baldios, máquinas industriais para locação e, fazendo a curva na avenida que se estreita, outras casas em pequenos terrenos. Uma barcaça espera o lento movimento da eclusa enquanto passo ansioso. Por enquanto, nada do pouco que eu esperava encontrar. Entramos na cidade?

78. Em Berlin Alexanderplatz. DÖBLIN, Alfred. Berlin Alexanderplatz. São Paulo, Martins Fontes, 2009 79. "A partir de 1923, são a final abertas as novas instalacões portuárias em construcão há uma dezena de anos. Berlim dispõe de 35 quilômetros de cais, milhares de metros quadrados de superfície para desembarque. Justamente em suas atividades como porto fluvial, que não são primeiro plano em sua vida econômica, a cidade desponta na frente, precedida apenas por Duisburg, porto exportador de carvão do Ruhr." RiCHARD, Lionel. "Uma identidade contraditơria'. In: Berlim, 1919-1933: a encarnaçãa .

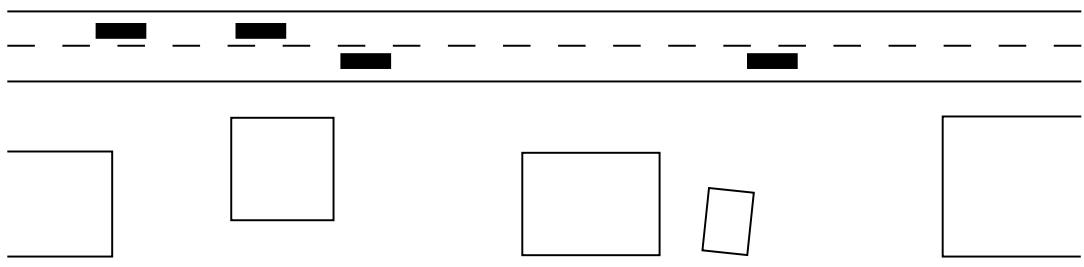


Sem aviso, a paisagem se abre em um grande cruzamento de avenidas, canais, um porto fluvial, linhas férreas, terminais e pontes, uma vasta e antiga zona industrial. Sobre a ponte que vence os trilhos a vista vai longe e alcança a estação de carga de Moabit, onde foi operada a deportação em massa de judeus que ainda viviam em Berlim, os chamados "Transportes", nome dado à importante ferramenta de execução da "Solução Final da Questão Judaica". De Berlim partiram em torno de cento e oitenta "Transportes" levando mais de quarenta e três mil e quatrocentas pessoas entre 1941 e 1945 para os guetos de Varsóvia, Lodz, Riga e Theresienstadt, por exemplo, ou para os campos de concentração e extermínio de Ravensbrück, Sachsenhausen, Bergen-Belsen e Auschwitz, para onde a grande maioria foi enviada ${ }^{80}$. Entre junho e setembro de 1942, época de preparação da ofensiva de verão na Rússia e a consequente impossibilidade de alocar trens especiais com grande capacidade de carga ${ }^{81}$ as saídas eram praticamente diárias, de segunda a sexta-feira, à vezes aos sábados, mas sempre respeitando os domingos, o dia do sagrado descanso. Nesse período fez parte da rotina dos soldados, dos funcionários da ferrovia e dos berlinenses ver diariamente os judeus, sempre em grupos de cinquenta ou cem pessoas, serem colocados em um ou dois vagões extras anexados aos trens de passageiros que partiam para o sul, com parada em Theresienstadt, o "gueto de idosos"s2, na hoje República Checa. 0 que pensavam os passageiros habituais desses trens? Se os anjos de Wim Wenders os acompanhassem, o que teriam ouvido? Entre essas viagens rotineiras de julho a setembro, embarcaram também oito grandes grupos de até mil pessoas indo para o sul ou para o leste, ação complicada que exigia a utilização de trens com vagões de carga e um contingente maior de soldados com seus cães e armas para controlar a potencia desordem e para viabilizar burocraticamente as listas de nomes e destinos $^{83}$. Assim como nos grandes carregamentos esporádicos que aconteceram até 1945 e, principalmente, na primeira semana de março de 1943, quando as maiores levas foram embarcadas, alcançando mais de mil e setecentas pessoas por trem. Toda essa movimentação deveria romper o ritmo normal da vida da cidade, deveria perturbar, ao menos momentaneamente, o movimento mecânico dos habitantes de Berlim, não poderia passar invisivel aos olhos embotados pela regularidade das operações diárias de uma metrópole industrial: o caminhão de lixo e a limpeza das ruas na madrugada, a entrega do leite pela manhã, o abrir de portas do comércio, a alternância de fluxos no cruzamento, o cartão no relógio de ponto, a partida do trem.
80. YAD VASHEM. Instituto internacional de pesquisa do holocausto. Disponivel em: <db.yadvashem org/deportation/page.html?!language=en>. Acesso em: 15 dez. 2013.

81. YAD VASHEM. Instituto internacional de pesquisa do holocausto. Disponivel em: <db.yadvashem. org/deportation/transportDetails.html? language =enEtitemld =5093041>. Acesso em: 15 dez. 2013. 82. YAD VASHEM. Instituto internacional de pesquisa do holocausto. Disponivel em: < db.yadvashem. org/deportation/transportDetails.html? language = enctitemld =5093041>. Acesso em: 15 dez. 2013 .

83. A ordem que dominava essas operaçōes, permitindo o controle estatístico demandado pelo regime, deixou um enorme rastro de documentos através dos qualis é possivel saber o nome, a data de ou aos campos de concentração e exterminio, base a partir da qual foi possivel estimar a dimensão do massacre e o destino de grande parte das vitimas.

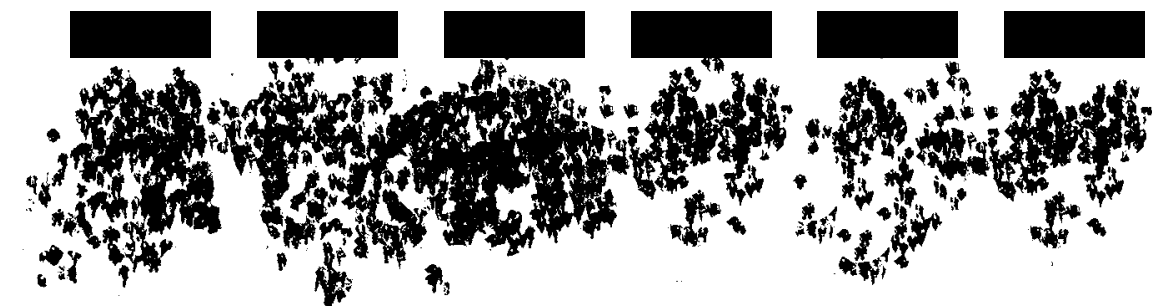


20. Descendo da elevação da ponte, mergulhamos na paisagem urbana Largas calçadas de pedra, edifícios de quatro ou cinco andares alinhados na testada do lote, o comércio em todo o térreo, de todos os tipos, carros e motos estacionados, muitas bicicletas, barracas de currywurst, caçambas, placas, pessoas passando, esperando o ônibus, chamando o táxi, conversando na esquina, o sinal va abrir, vai abrir, um quarteirão que não tem fim, árvores e a torre de uma igreja luterana. Rua, avenida, viaduto. A linha do metrô de superfície passa ali em cima. Passando sob ele, a paisagem mais uma vez se abre: atravessamos um bairro inteiro e alcançamos uma zona institucional da cidade onde o Spree faz uma curva acentuada e se liga ao canal que leva ao porto. Em frente à gigantesca estação central de Berlim, a Hauptbahnhof, descemos por engano do ônibus. A vista vai bem longe e, em um esforço para me localizar, avisto a cúpula do Reichstag e a famosa torre de TV, esforço que em nada nos ajuda. Nessa grande esplanada, com as construções da cidade lá longe, o peso das malas e das nuvens escuras anunciando um dilúvio, experimento uma sensação similar àquela de quando desci sozinho do último ônibus coletivo na Plataforma Rodoviária de Brasília: Qual é o rumo? Sprechen sie englisch? Táxi!

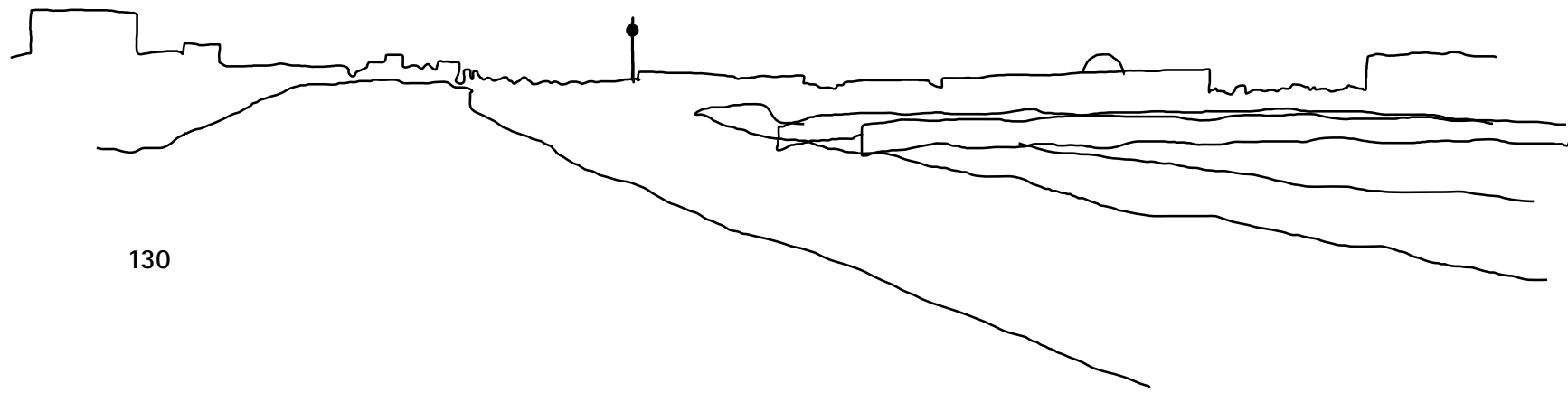

21. Linienstraße 53, please. Saímos da esplanada e mergulhamos em um novo bairro. Foi só passarmos novamente por baixo do viaduto metálico do S-Bahn e a paisagem instantaneamente voltou a se fechar nos corredores sombreados formados pelos edifícios alinhados na calçada, de forma um pouco diferente da outra, entretanto. Talvez um pouco mais regular nas alturas, mais estreita, com edifícios aparentemente mais solenes, certamente menos arborizada, talvez com um comércio menos intenso nos térreos, diferenças que me permitem identificar um novo bairro. Estamos no Mitte, no centro, já dentro dos limites da cidade no século XVIII e da Berlim Oriental no século XX, uma coincidência de limites que marca diversos pontos da cidade, incluindo a área do Memorial. Contorço meu corpo para, da janela oposta, ver a fachada da Nova Sinagoga, que sobreviveu aos incêndios da Kristallnacht em 1938, mas foi destruída com os bombardeios. Os judeus tinham forte presença nesse bairro e nos arredores e a construção dessa grande sinagoga foi um marco no crescimento da comunidade em Berlim. Logo aqui ao lado, na Große Hamburger Straße, também ficava um antigo cemitério, usado desde 1672 e destruído pelo regime nazista em $1943^{84}$, e o Lar de Idosos da comunidade, que no mesmo período foi convertido em um dos acampamentos-prisão que temporariamente abrigaram os judeus antes das deportações. Chove.

84. KOPPENFELS, Johanna von. Jewish cemeteries in Berlin. Berlin, Berlin Edition, 2005, p.32.

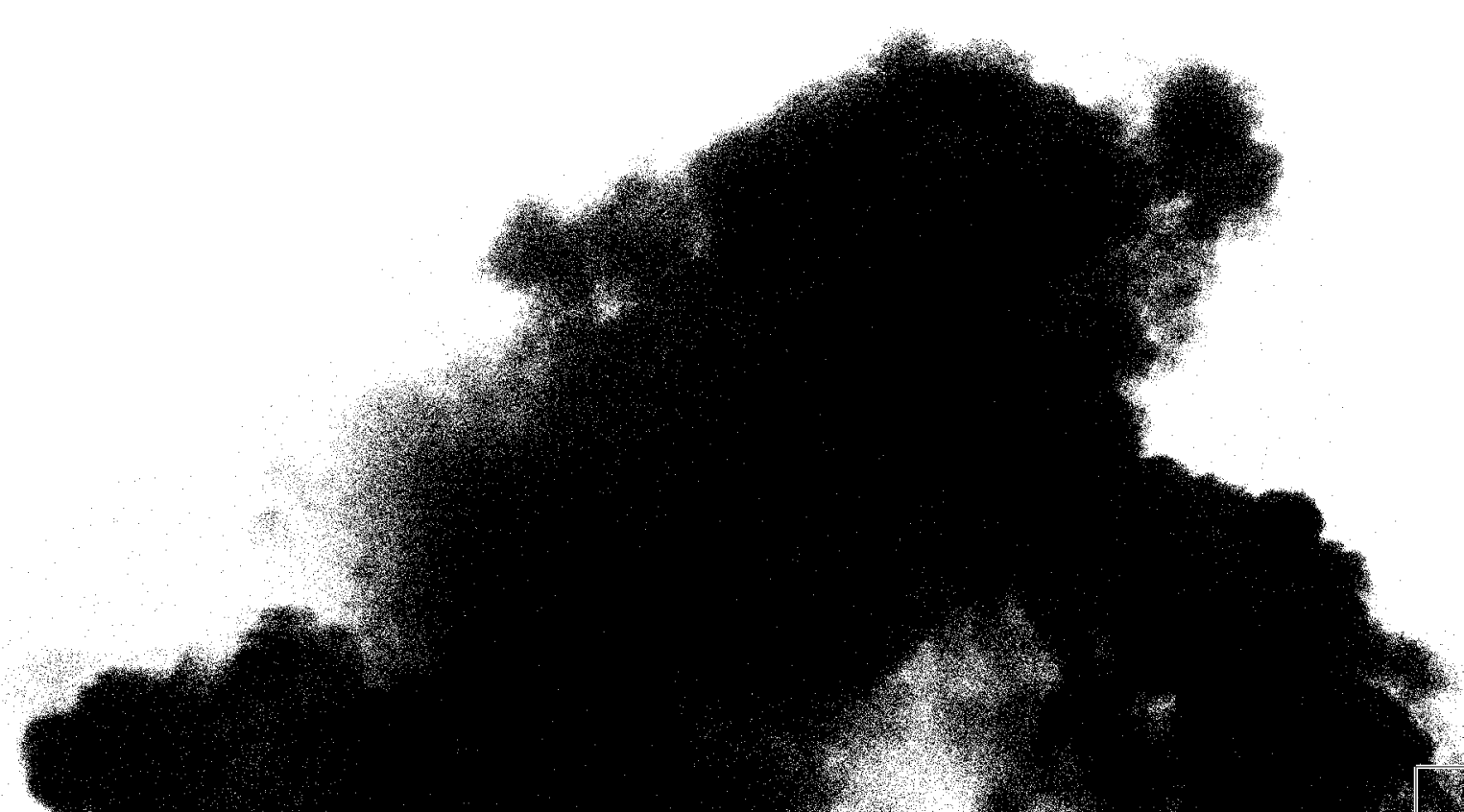


No comeco do século XX, daqui até a Alexanderplatz estendia-se uma área chamada na época de Scheunenviertel (algo como "região dos celeiros") habitada por uma população proletária, antigos camponeses, operários e judeus oriundos do Leste da Europa que chegaram, muitas vezes, apenas com a roupa do corpo. Esses, imigraram para cá desde a Primeira Guerra, quando milhares foram trazidos como trabalhadores da indústria bélica ou da construção da rede ferroviária, muitas vezes por meio de violência, e ao longo dos anos seguintes, quando a retirada das tropas alemãs e as profundas mudanças da revolução russa tumultuaram o leste europeu e provocaram "uma tempestade de

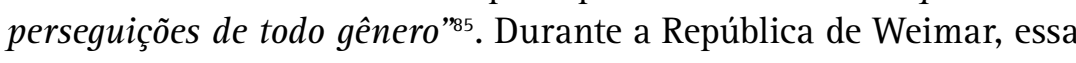
área era "uma espécie de território inimigo, o universo do mercado negro, dos jogos de azar, dos hotéis suspeitos, das mulheres baratas" "No Scheunenviertel, orava-se em quartos vizinhos a outros cômodos arrumados como cervejarias rudimentares. Os piedosos viviam ao lado de impudicos, as associações religiosas judaicas ao lado do sindicato do crime. Os santos e as meretrizes moravam no mesmo andar. Em suma, era o centro de todos os amálgamas, e, assim sendo, evidentemente, era fácil de confundir o rabino com o bandido. Para os contemporâneos, as ruas atrás da Alexanderplatz, bem como o bairro dos malfeitores em torno da Schlesischer Bahnhof [atual Ostbahnhof], constituiam um aqui onde cresceu e viveu durante grande parte de sua vida o escritor Alfred Döblin, e é aqui onde vive o seu anti-herói, Franz Biberkopf percorrendo os bares e prostíbulos, se encontrando com os judeus da Gormannstraße, vendendo jornais na Alexanderplatz, tentando permanecer honesto e envolvendo-se em trapaças.

85. GEISEL, EEke. "Excluidos e delinquentes". In: Berlim, 1919-1933: a encarnação extrema da modernidade. Rio de Janeiro, Jorge Zahar, 1993, p.58.

86. GEISEL, Eike. "Excluidos e delinquentes". In: Berlim, 1919-1933: a encarnação extrema da modernidade. Rio de Janeiro, Jorge Zahar, 1993, p.57.

87. GEISEL, Eike. "Excluídos e delinquentes". In: Berlim, 1919-1933: a encarnação extrema da modernidade. Rio de Janeiro, Jorge Zahar, 1993, p.60.

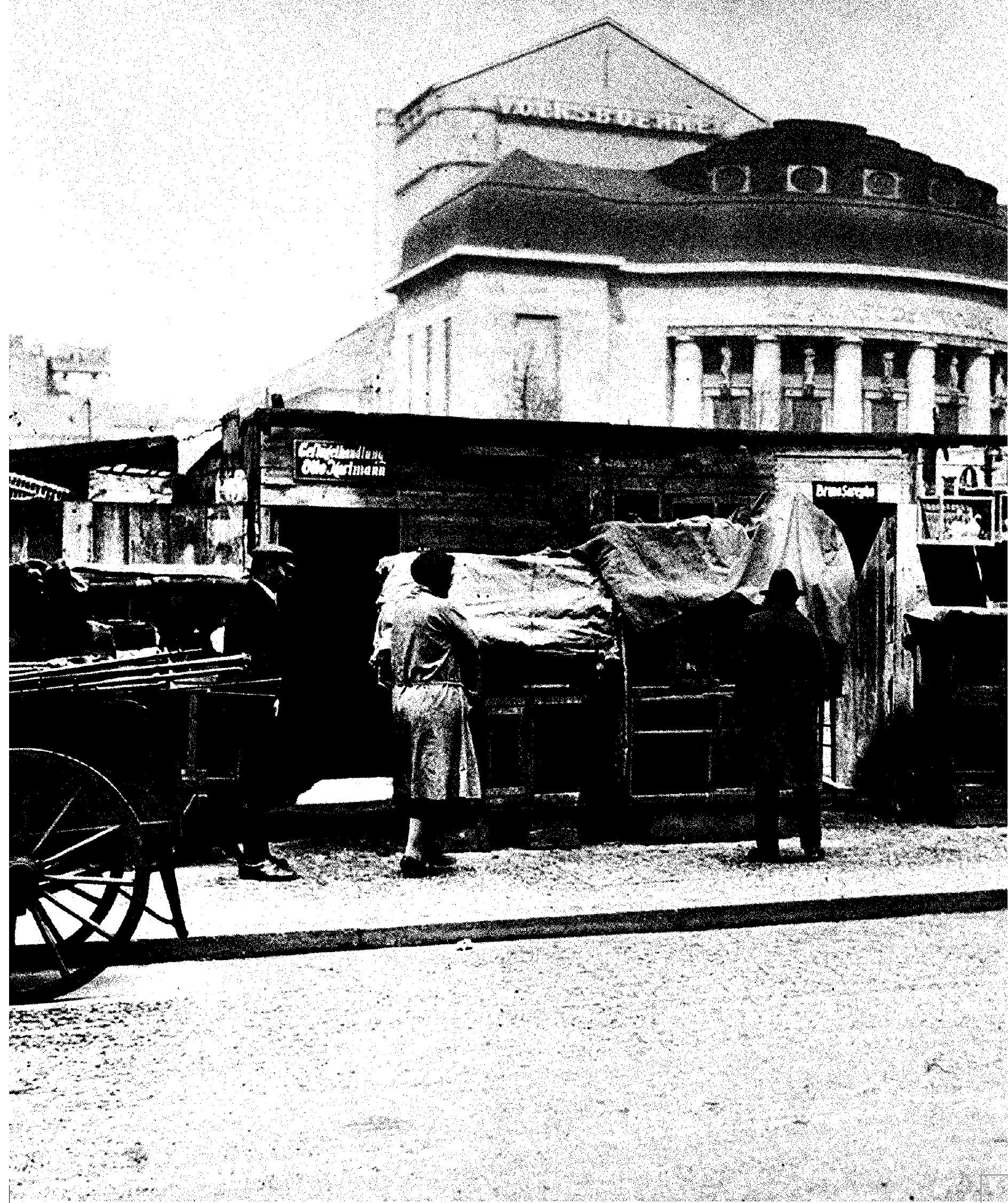



Cuidadosamente colocada ali para que eu tropeçasse nela. Aqui viveu Hermann Wolff, nascido em 1880, deportado em 1943, assassinado em Auschwitz. Gunter Demnig, artista berlinense que desde 1997 fabrica as peças de bronze e concreto com gravações de nomes de vítimas do nazismo, sejam elas judeus, ciganos, gays ou membros da resistência ao regime, instalou pessoalmente a maioria delas, que já passam de 43500 espalhadas em diversos países da Europa, nos seus últimos locais de residência. "Os Stolpersteine na frente dos edifícios trazem de volta à memória as pessoas que um dia viveram aqui. Cada 'pedra' começa com um 'aqui viveu'... Uma "pedra'. Um nome" ${ }^{{ }^{9} 9}$. A proposta artística acabou por converter-se em uma espécie de ofício, o de artista-calceteiro, ou de empresa que oferece ao seu público a instalação de um pequeno monumento: "Por 120 euros, qualquer pessoa pode patrocinar uma pedra, sua manufatura e instalação. Por favor, escreva para info@stolpersteine. eu para mais informações" ${ }^{\circ}$. Promovida de maneira pulverizada, a instalação das pedras se dá em contextos que variam de acordo com seus financiadores: de pequenas, mas solenes cerimônias, com discursos, aplausos, rezas e flores sobre a calçada, à rudeza das marretadas desferidas solitariamente pelo artista em uma cena que facilmente poderia ser confundida com o serviço de manutenção do passeio público. Por outro lado, a obra dificilmente alcançaria essa dimensão e certamente ganharia outros sentidos se dependesse unicamente da iniciativa e do financiamento de um governo ou de uma empresa. Conheco a obra. Sei que ainda toparei com outras pelo caminho. E a inscrição no bloco não deixa margem para

88. Em uma tradução livre: "pedra de tropeço".

89. STOLPERSTEINE. Projeto de arte para a Europa por Gunter Demnig. Disponivel em: <www.stolpersteine.eu>. Acesso em: 15 dez. 2013. Tradução nossa.

90. STOLPERSTENE. Projeto de ante para a Europa por Gunter Demnig. Disponivel em. <www.stolpersAcesso em: 15 dez. 2013. Tradução noss 
dúvida: aqui viveu uma vítima do nazismo. Mas a superfície de bronze - que me lembra uma placa comemorativa, dessas que se encontra em pontos turísticos da cidade anunciando fatos e figuras históricas ${ }^{91}$ - parece contaminar com a sua frieza institucional o nome que nela é gravado. Hermann Wolff é o nome na Stolperstein da Linienstraße n 53 . Hermann Wolff é o item $3871181^{92}$ da Base de Dados Central dos Nomes das Vítimas da Shoah. E um nome e um número. E, de novo, parte de um enorme esforço de catalogação: o primeiro feito para garantir seu desaparecimento e o segundo para tentar resgatá-lo. Hermann Wolff é a criança que nasceu em 21 de fevereiro de 1880 em Schubin, uma pequena cidade em Posen, antiga província da Prússia. Antes da Segunda Guerra Mundial, já em idade adulta, viveu em Berlim, em algum dos apartamentos deste mesmo edifício onde estou hospedado. Um quarto, sala e cozinha, pagando mensalmente 24,15 reichsmarks ${ }^{93}$. Todos os dias, ao chegar em casa, abria essa mesma porta, atravessava esse mesmo pátio escuro e subia as mesmas escadas de madeira. Talvez também sentisse o incômodo que sinto com a relação ergonomicamente errada entre o piso e o espelho dos degraus: a essa altura, a idade já começava a pesar nas suas costas. Trabalhava fabricando vassouras e escovas a quatro quadras daqui, na Blindenwerkstatt Otto Weidt. Talvez seja um dos rostos não identificados da antiga fotografia de grupo. Hermann era cego. Além disso, devia já ser considerado um velho pelos soldados nazistas que o cercavam. Provavelmente veio morar aqui pela proximidade da instituição onde poderia manter-se trabalhando e não ser considerado uma peça descartável.

91. Berlim possui 2916 placas comemorativas, a grande maioria delas dedicadas a vitimas ou opositores

92. YAD VASHEM. Instituto internacional de pesquisa do holocausto. Disponivel em: <db.yadvashem $\mathrm{org} /$ names/nameDetails.html?itemld =3871181 \&language=en>. Acesso em: $15 \mathrm{dez} .2013$.

93.STOLPERSTEINE IN BERLIN. Disponivel em: <www.stolpersteine-berlin.de/en/biografie/763>. Acesso em: 15 dez. 2013
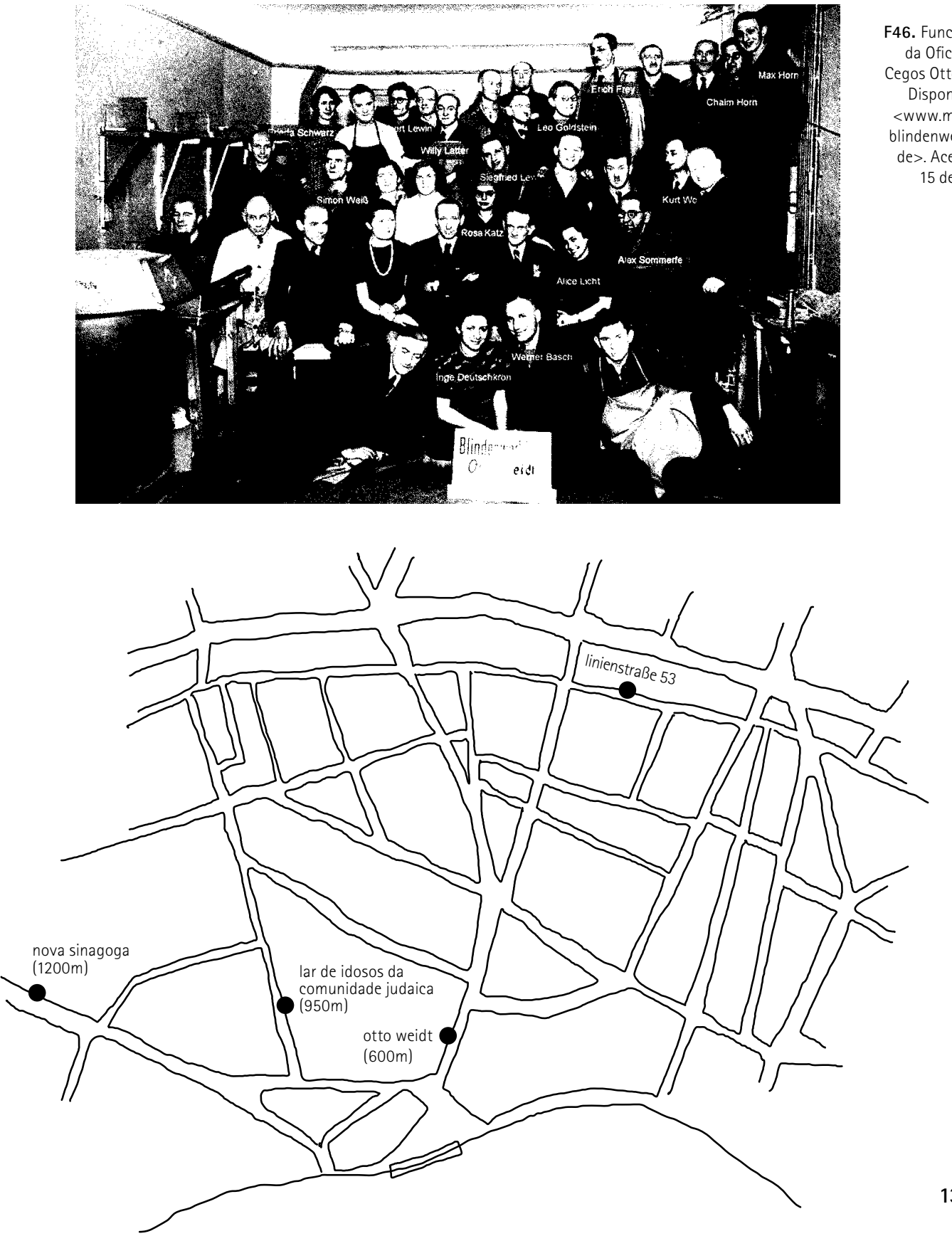
Seis dias depois do seu aniversário de 63 anos, no dia 27 de fevereiro de 1943 , foi levado do seu local de trabalho junto com os outros judeus cegos para um dos muitos acampamentos instalados na cidade, na Große Hamburger Straße ${ }^{\circ} 26^{94}$. Nas seis noites que passou lá, deve ter sentido fome, sede e frio, pois ainda era inverno e o edifício onde antes funcionava um abrigo para idosos mantido pela comunidade judaica não tinha camas, banheiros e nem provisões suficientes para todos. No dia 06 de março foi levado junto com outras 661 pessoas $^{95}$ (dos quais 479 eram mulheres ou crianças) para o norte da cidade na estação de carga de Moabit. Foi colocado em um vagão de gado do Osttransport 35 (o trigésimo quinto trem para o leste) e levado para o campo de extermínio de Auschwitz Birkenau ${ }^{96}$, na Polônia, onde desapareceu dos registros e censos. Hermann era solteiro, mas deve ter ficado aflito ou ter presenciado outros homens ficarem por suas famílias separadas: homens, mulheres e crianças, cada um para um canto. Como era cego, provavelmente não foi selecionado para o trabalho forçado, sendo assim logo mandado para as câmaras de gás. Hermann Wolff era o número 87 na lista de deportados de 06 de março. Na mesma lista estavam Amalie Wolff (66 anos) ${ }^{97}$, Natalie Wolff (39 anos) ${ }^{98}$, Harry Israel Wolff (13 anos) e Judith Ruth Sara Wolff (10 anos) ${ }^{99}$. Familiares? Como saber?... Seus nomes não estão aqui. Hermann Wolff está sozinho entre as pedras da calçada.

94. MUSEUM BLINDENWERKSTATT OTTO WEIDT. Disponivel em: <www.museum-blindenwerkstat. de/en/ausstellung/themen/the-situation-in-the-workshop-for-the-blind>. Acesso em: 15 dez. 2013 95. UNITED STATES HOLOCAUST MEMORIAL MUSEUM. Disponivel em: <www.ushmm.org/online/hsv/

96. Das seiscentas e sessenta e duas pessoas levadas para Auschwitz no Osttransport 35, cento e cinquenta e trés homens receberam os números de 107164 a 107316 e seis mulheres receberam os números de diretamente para a câmara de ǵs de Birkenau (Auschwitz II) Segundo os registros, apenas nove prisioneiros desse transporte sobreviveram ao massacre. YAD VASHEM. Instituto internacional de pesquisa do holocausto. Disponivel em: $<$ db.yadvashem.org/deportation/transportDetails.html?language=enctitemld=5092744\#! prettyPhoto>. Acesso em: 15 dez. 2013.

97. STATSSTK DES HOLOCAUST. Estatisticas sobre a deportaçăo da populaçăo judaica durante o nazismo. Disponivel em: <WWW.Statistik-des-holocaust.de/0T35-3.jpg>. Acesso em: 15 dez. 2013.

98. Idem. Disponivel em: <www.statistik-des-holocaust.de/0T35-16.jpg>. Acesso em: 15 dez. 2013.
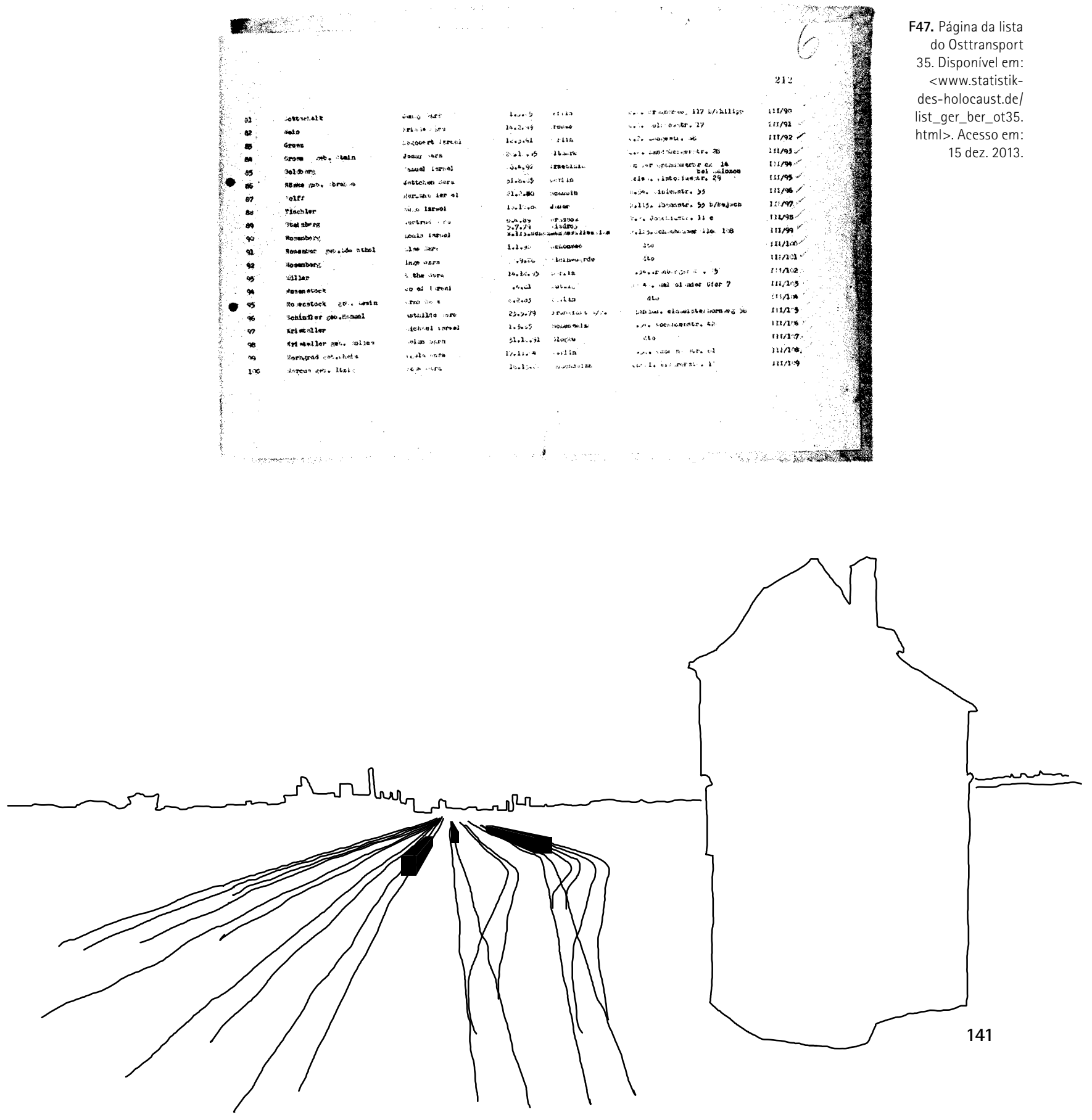

ram-se outras seis pedras: Israel Kessler, Maria Kessler, Oskar Kessler Adolf Kessler, Betti Kessler e Moritz Kessler ${ }^{100}$, uma família inteira deportada em 1943 e enviada a Auschwitz. Mais alguns poucos passos, junto ao meio-fio, quatro pedras formando um quadrado: Esther Szydlo ${ }^{101}$, Salomon Szydlo, Harry Szydlo e Paula Szydlo, mãe e filhos enviados ao gueto de Riga. Na esquina com a Alte Schönhauser Straße, três pedras em um triângulo: Rosa Michaelis ${ }^{102}$ Ludwig Kahn e Meta Kahn, enviados a Auschwitz. Paro mais uma vez no mercadinho onde comprei pão, manteiga e suco de maçã para o café da manhã de hoje: Walter Boldt ${ }^{103}$. Já atrasado no meu percurso até o Memorial, vou passando sem tropeçar por outras espalhadas pelo caminho. A rotina dos moradores dessa rua é permeada por essas pedras, cravadas na calçada com a intenção de lembra-los diariamente dos antigos vizinhos assassinados. Me pergunto se ainda escutam o lembrete. Talvez já tenham se acostumado com a repetição, transformado os nomes e datas de aniversário das vítimas em mais umas das inúmeras inscrições que pontilham a paisagem urbana, o caráter oficial, solene e duradouro do bronze em simples cor cintilante, percebendo a sua existência, mas esquecendo-se momentaneamente do seu significado habitual, como quando eu desço a Rua São Bento e acho graça na confusão de palavras do grito dos anunciantes sem me dar conta de que preciso de uma armação nova. “Óticaóticaóticaótica!”. Talvez, às vezes, sem querer se surpreendam novamente com a palavra "assassinado", lembrando da finalidade dos blocos. As crianças, que ainda não a aprenderam, talvez se divirtam em encontra-las, guardando-as em coleções imaginárias, definindo padrões, regras e procedimentos para o desafio, como em um desses jogos inventados para dar sentido à caminhada entre casa e a escola: não pisar nas linhas, caminhar sobre o meio-fio, arrancar uma folha da grande árvore, contar as pedras douradas.
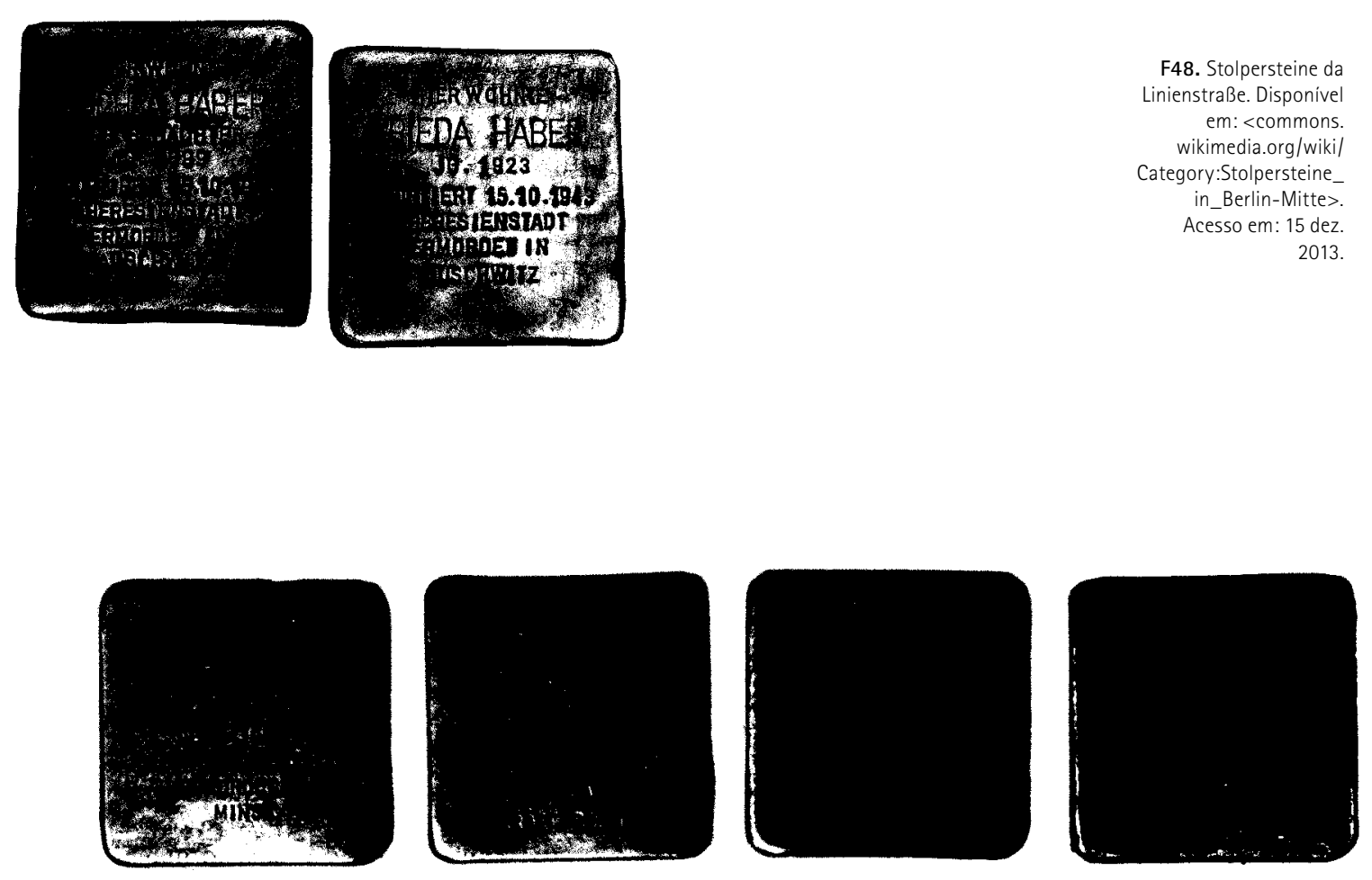

100. Idem. Disponivel em: <www.stolpersteine-berlin.de/en/biografie/319>. Acesso em: 15 dez. 2013 101. Idem. Disponivel em: <www.stolpersteine-berlin.de/en/biografie/68>. Acesso em: 15 dez. 2013. 102. Idem. Disponivel em: <www.stolpersteine-berlin.de/en/biografie/3541>. Acesso em: 15 dez. 2013 
Enquanto Gunter Demnig crava mais uma pedra na calçada, Uta Franke, sua parceira e coordenadora do Stolpersteine, se debruça sobre o mapa da Alemanha aberto no chão do escritório: "E Herdecke... está feita...”104. Com alfinetes vermelhos, verdes e amarelos marca as cidades conquistadas, construindo o diagrama de alcance territorial e concentração do projeto. "O maior projeto de celebração do mundo"105, diz o site da iniciativa em Munique. "Toda grande cidade tem as pedras, exceto Munique, pois eles negaram a autorização. Mesmo as menores vilas as têm, mas a Bavária é o estado com o menor número. Esqueci Nördlingen... Ou ela pertence a BadeVurtemberga? Não, ela ainda é na Bavária". E crava mais um alfinete vermelho. "Ainda assim há mais pedras em Mecklenburg. Mesmo que as manchetes de lá estejam repletas de histórias neonazistas, há mais localidades envolvidas no projeto do que na Bavária” ${ }^{106}$. Uta certamente faz alusão ao fato de Munique ter sido o berço do nazismo. A oposição às Stolpersteine em Munique, entretanto, não foi liderada por um político de direita, mas por Charlotte Knobloch, presidente da comunidade judaica de Munique e Alta Baviera - a segunda maior da Alemanha -, que considerou que a ideia desonrava os nomes das vítimas gravadas nas pedras ao expô-las ao pisoteamento diário de transeuntes. Em outro foco de resistência ao projeto, na cidade de Krefeld, Michael Gilad, o presidente da comunidade judaica local, se colocou à frente da oposição ao dizer que as pedras o faziam lembrar dos desmontes de cemitérios de judeus promovidos pelo regime nazista, nos quais as lápides eram reaproveitadas na pavimentação de passeios públicos.

104. STOLPERSTEIN. Direção: Dörte Franke. Alemanha : Film Kino Text, 2008. 1 DVD (73 min), color. Tradução nossa.

105. STOLPERSTEINE INITIATIVE FÜR MÜNCHEN. Disponivel em: <www.stolpersteine-muenchen.de/ english.php>. Acesso em: 15 dez. 2013. Tradução nossa.

106. STOLPERSTEIN. Direção: Dörte Franke. Alemanha : Film Kino Text, 2008. 1 DVD (73 min), color. Tradução nossa.
Ao estabelecer a analogia entre cada uma das vítimas do Holocausto e as pedras instaladas na frente das suas antigas residências - "Uma 'pedra'. Um nome"107,108-, ao usar um material como o bronze, tão fortemente ligado à imagem de placas comemorativas e de identificação de túmulos, assim como, ao criar a associação do caminhar na cidade com o caminhar em um cemitério - um grande e difuso cemitério urbano, associação enormemente reforçada pelas inúmeras imagens espalhadas pela $w e b$, nas quais visitantes depositam flores ao lados das pedras ${ }^{109}-$, o projeto criou para si a armadilha na qua foi mais tarde capturado. 0 uso de uma representação simbólica da individualidade das vidas exterminadas e da ideia de morte através da imagem do cemitério parece ter sido crucial na maneira como a obra foi recebida nessas duas ocasiões. Ao mesmo tempo, a obra tem no seu cerne uma relação de enfrentamento com o passado que incomodou alguns outros, como o prefeito de Munique, que disse já haver um excesso de memoriais e cerimônias comemorativas do Holocausto. Em defesa da expansão da sua obra para a cidade, e questionando a listagem de nomes em memoriais e museus, $o$ artista argumenta que esses espaços fechados podem ou não ser visitados, enquanto que as pedras na calçada podem ser (e serão, obrigatoriamente) vistas por todos. Filho de um ex-militar nazista - passado que ele descobriu apenas aos 18 anos e do qual seu pai se recusava a falar -, Gunter Demnig faz parte de uma geração de alemães que

107. STOLPERSTEINE. Projeto de arte para a Europa por Gunter Demnig. Disponivel em: <www.stolpersteine.eu>. Acesso em: 15 dez. 2013. Tradução nossa.

108. 0 artista diz ainda, a respeito dessa analogia: "Eu nunca abriria uma fábrica onde as pedras seriam calizados em forma de linha de montagem. Eu penso gue coda pedra deve ser foita à mão, de mo que cada destino individual seja restaurado". STOLPERSTEIN. Direção: Dörte Franke. Alemanha : Film Kino Text, 2008. 1 DVD (73 min), color. Tradução nossa.

109. Outras açōes curiosas também contribuem para isso, como os grupos organizados através de redes sociais, que, assim como as dedicadas viúvas que zelam pela conservação impecável dos túmulos de seus maridos, voluntariamente percorrem as ruas das cidades munidos de panos e produtos de limpeza removendo a camada escura que naturalmente se forma com a oxidação do material, devolvendo assim a polidez inicial da peça 
estabeleceu uma relação bastante conflituosa com a história recente do país. Pensando na sua trajetória e levando em conta as declarações em que atribui aos trabalhos de "arte pública" um maior poder de transformação social, pode-se comparar as Stolpersteine a uma manifestação em praça pública, a uma obra-denúncia que, portanto, se faz de maneira dependente da sua visibilidade e extensão. Guardadas ou instaladas dentro das casas, como é o caso das pedras de Munique ${ }^{110}$ que permanecem vetadas no espaço público, a principal intenção da obra se perde, ou seja, a de se impor à rotina e aos olhos dos cidadãos. Gunter Demnig quer, com suas pedras ostensivamente colocadas nas calçadas, escancarar um passado obscuro, obrigar os moradores das ruas a ler todos os dias os nomes das vítimas do regime totalitário do qual, muitas vezes, fizeram parte ou com o qual foram coniventes.

110. TAZ. Versão eletrônica do jornal diário. "Wer gedenkt am besten?". Disponivel em: <www.taz. de/!19361>. Acesso em: 15 dez. 2013.

111. YOUNG, James E. Germany's vanishing Holocaust monuments. Disponivel em: <www.gerz.fr/deb/ put_file.htm|?ident=d0cb109e93e99da34f3ffff7ae44de24>. Acesso em: 15 dez. 2013. Tradução nossa 112. Um material que, além da maleabilidade que possibilitava a gravação dos nomes, conferiu à obra
uma superficieie cinza-escuro bastante regular.
Jochen Gerz, outro artista berlinense que cresceu entre as ruínas da cidade e do nazismo, executou um movimento contrário ao de Demnig, construindo duas obras que, ao invés se imporem visualmente para se contrapor ao silêncio que marca a memória do holocausto, exploraram a ideia de ausência para falar do extermínio: dois monumentos "invisiveis", ou "contra-monumentos" "Memorial Contra o Facismo", feito em parceria com Esther ShalevGerz na cidade de Hamburgo, a população da cidade era convidada gravar seus nomes em uma monumental coluna de aco revestido de chumbo ${ }^{112}$ com 12 metros de altura - lembrando a forma arquetípica de um obelisco - , configurando um enorme abaixo-assinado contra o fascismo. À medida que a superfície acessivel em altura era preenchida pelas assinaturas e mensagens, a coluna era lentamente engolida por sua base até que dela restasse apenas a marca do seu topo no plano do chão, um movimento de submersão que se deu ao longo de mais de sete anos, de outubro de 1896 a novembro de 1993. 
Perto de onde estamos, assim como em diversas áreas da cidade, é possível ver imensos lotes vagos e edifícios inteiros caindo aos pedaços, alguns deles ocupados por jovens artistas, punks, hippies e desempregados. Por toda parte, empenas cegas com os resquícios de uma antiga construção: o desenho de um telhado de duas águas bastante inclinadas, a marca de pavimentos e escadas, azulejos de uma cozinha, de um banheiro, um quarto pintado de azul e o outro de amarelo. A entrada deveria ser por aqui. Enormes álbuns de retratos, que Berlim parece há muito tempo colecionar, em exposição para os olhos de todos e de toda a cidade. Como no filme de Rosselini, a vida ainda segue entre as ruinas.
29. Em São Paulo, provavelmente esses lotes passariam despercebidos. Mas aqui não. Aqui o caminhar de miradas com poucas surpresas - para aquele que logo entende que há uma regra para fazer a cidade - sempre seguindo o alinhamento das fachadas, a altura regulada das construções, fatalmente se volta para esses espaços vazios: transborda de seu fluxo normal. 0 primeiro que vi, logo ao lado de onde ficamos, estava ocupado por um jardim que criava uma conexão com o miolo de quadra. Fomos entrando sem saber se era ou não permitido. Arbustos, gramíneas floridas, pequenas árvores, o chão de terra batida, um banco de madeira no canto, uma mulher lendo um livro e, entre as folhagens lá no fundo, a sombra de alguém entrando por uma porta. Achei lindo. Mas depois me dei conta: aquilo não era um simples jardim, era o vazio de uma ruína que não havia sido reocupado.

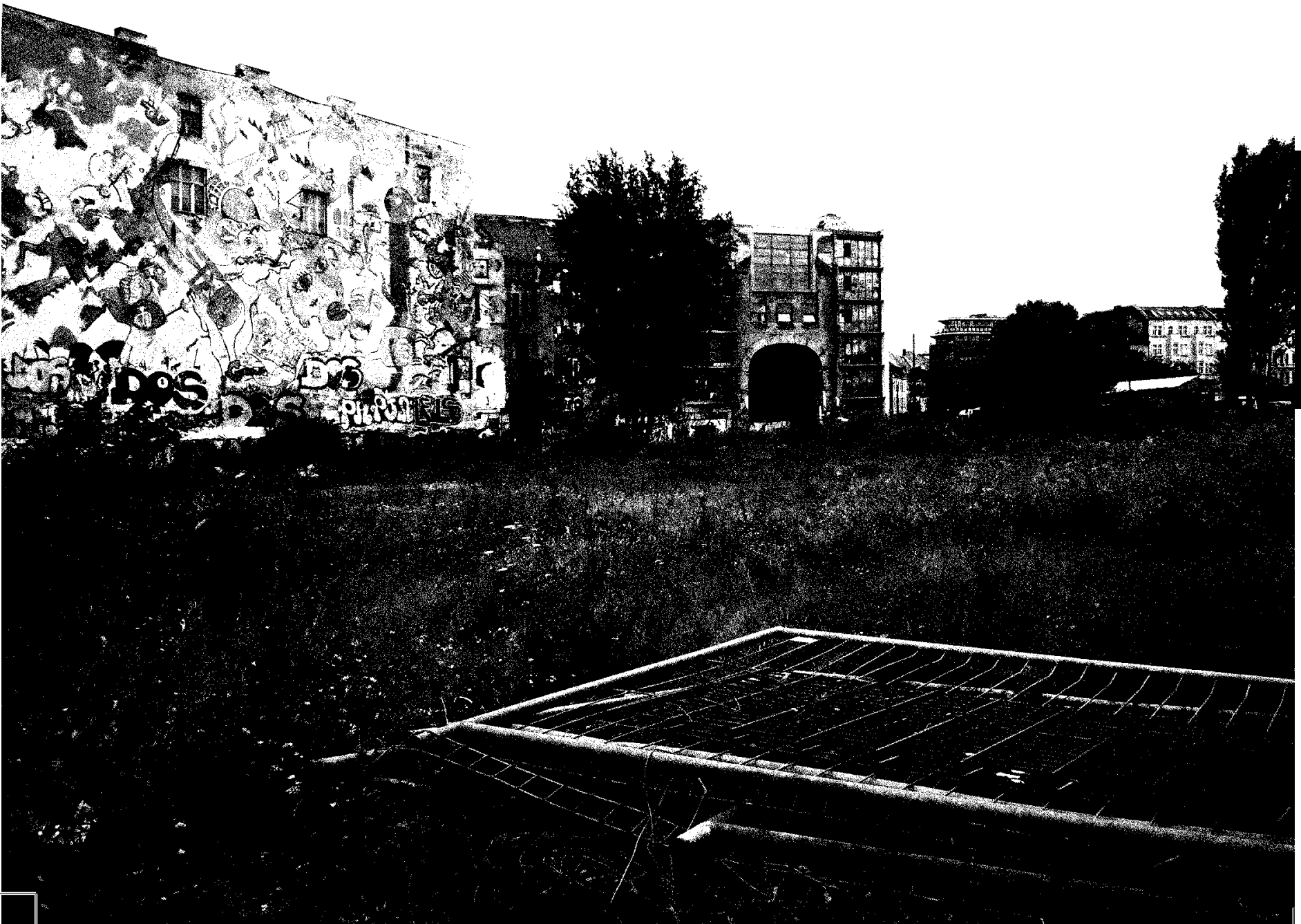


As ruínas tinham um especial

significado na arquitetura desen-

volvida pelo principal arquiteto do

Terceiro Reich, Albert Speer, uma das

figuras mais próximas de Hitler e com quem o

governante compartilhava suas frustradas aspi-

rações artísticas. Em sua autobiografia publicada em

1969, após ter cumprido a sua pena de vinte anos no

presídio de Spandau, no extremo oeste de Berlim, o

arquiteto narrou o episódio da construção dos campos

de desfile em Nuremberg, o Zeppelinfeld, registrados

pelas lentes de Leni Riefenstahl em Triumph des

Willens. "Hitler gostava de dizer que o propósito das

suas construçoes era o de transmitir seu tempo e seu es-

pirito para a posteridade. Em última instância, tudo o que restou para lembrar dos homens das grandes épocas da história foi sua arquitetura monumental, ele filosofava. O que havia restado dos imperadores de Roma? O que daria seu testemunho hoje se seus edifícios não tivessem sobrevivido? Periodos de fraqueza serão inevitáveis na história das nações, ele argumentava, mas no seu pior periodo, sua arquitetura irá falar com eles sobre o seu antigo poder. Naturalmente, uma nova consciência nacional não poderá despertar somente através da arquitetura. Mas quando depois de um longo periodo de inércia, uma noção de grandeza nacional é renovada, os monumentos de ancestrais são as mais impressionantes exortações. Hoje, por exemplo, Mussolini pode apontar para as construções do Império Romano como símbolo de um espirito heroico de Roma. Assim ele pode incendiar sua nação com a ideia de um império moderno. Nossas arquiteturas devem também falar com a consciência de uma futura Alemanha séculos adiante. No âmbito desta argumentação Hitler também destacou o valor de um tipo permanente de construção"
Assim que a construção do Zeppelinfeld

começou, uma area usada para o estacionamento de bondes teve que ser demolida. Segundo conta Speer, após a demolição as armaduras de aço das construções já apresentavam os sinais da corrosão, oferecendo a ele, que visitava o local destruído, uma "visão sombria" que o levou a desenvolver e apresentar a Hitler o que ele chamou de "Uma Teoria do Valor da Ruína", que basicamente tratava da materialidade das construções modernas imaginando seu futuro como ruina. "Para ilustrar minhas ideias, eu preparei alguns desenhos românticos. Eles mostravam como o palanque do Zeppelinfeld estaria depois de gerações de negligência, cobertas de hera, com suas colunas caidas, as paredes em ruinas, aqui e ali, mas os contornos ainda claramente reconheciveis. Na comitiva de Hitler esses desenhos foram considerados uma blasfêmia. Que eu pudesse senhos imaginar um periodo de declinio do recém-fundado Reich, destinado a durar mil anos, parecia ultraj-fundado Reich

destinado a durar mil anos, parecia ultrajante para muitos dos seguidores mais próximos de Hitler. Mas ele mesmo aceitou minhas as como logicas e iluminadoras. Deu ordens para que no futuro as construçôes importantes do seu Reich fossem erguidas sob os princípios da 'lei das ruínas"' 114 . Mais tarde, em plena e frenética construção da área de desfiles de Nuremberg, declarou o local como de interesse histórico: "Se em um futuro distante arqueólogos escavarem aqui e encontrarem o granito, deixe que fiquem estupefatos diante da grande revelação que estremecerá o mundo!"115.

113.SPEER, Albert. Inside The Third Reich. New York, The Macmillan Company, 1970, p.55. Tradução nossa. 114. SPEER, Albert. Inside The Third Reich. New York, The Macmillan Company, 1970, p.56. Tradução nossa. 115. ARQUITETURA da destruicão. Direcão: Peter Cohen. Narracão: Bruno Ganz Suécia: Svenska Filminstitute [producão): Poj Filmproduction AB [producão): Film \& Teater [producãol 1989 [producão] São Paulo: Versátil Home Video, 2006. 1 DVD (121 min.), color, p\&tb. Titulo original: Undergangens Arkitektur. Tradução nossa. 
0 jeito de manter os jardins, com plantas crescendo livremente misturadas umas às outras (em competição?), sem espécies consagradas como ornamentais, com os matinhos se esgueirando entre as frestas de construção, invadindo partes da calçada, atravessando cercas e gradis sem que ninguém aparentemente se importe com isso, despertou em mim um misto de admiração, pela beleza dessa natureza rude e ao mesmo tempo doméstica, e melancolia, pela impressão que às vezes pode dar (para alguém acostumado a ver os ridículos canteiros de grama cortada nas calçadas) de que as coisas talvez não vão muito bem. Lembro-me do garoto do filme do Rosselini andando pela Berlim destruída e sentando na calçada para chorar a sua responsabilidade pela morte do velho pai. Poderia ser essa daqui: essas mesmas plantas crescendo sobre o mosaico de pedras, lentamente abrindo espaço entre elas e essa mesma guia robusta de pedra maciça.

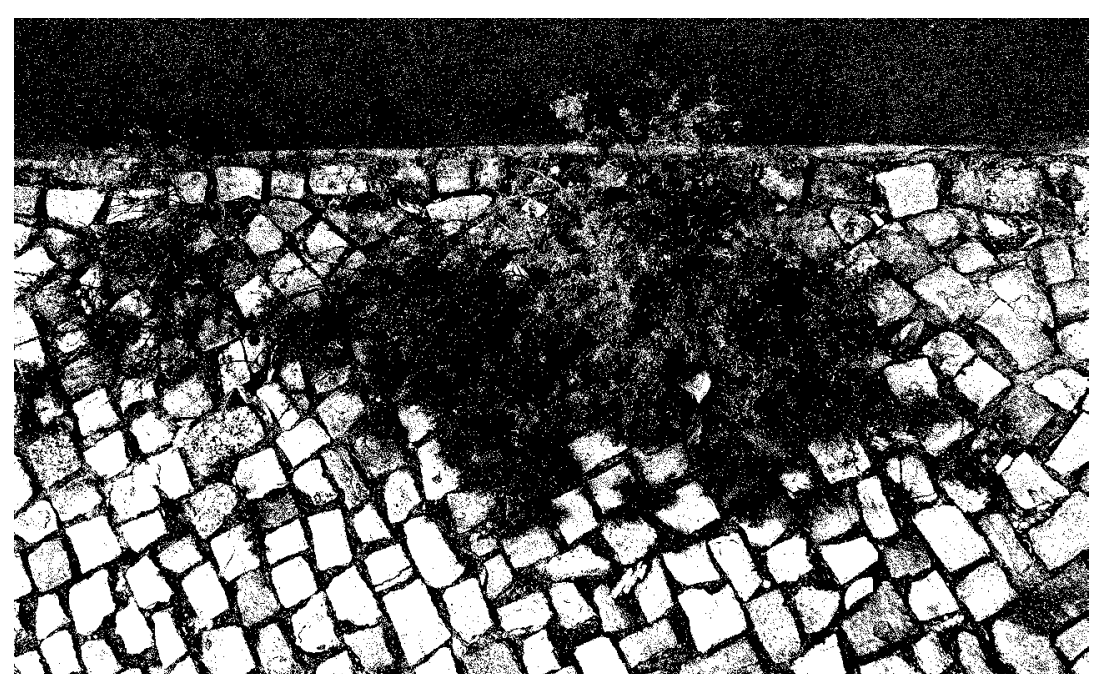

32. Caminho em direção à Fernsehturm, a torre de TV construída na década de sessenta para emitir ondas eletromagnéticas e ser um estandarte da RDA. A particular combinação formal que ostenta uma grande coluna que se estreita da base para o topo, uma esfera reluzente ricamente decorada, e uma esguia antena pintada com faixas de vermelho e branco - traz certa lembrança da Rússia: algo da Torre de Ostankino, sua irmã maior e mais velha, e algo do coroamento das cúpulas douradas do Kremlin. À medida que avanço pelo sistema de pequenas ruas da área mais preservada do antigo Scheunenviertel e me aproximo do seu limite, a Alexanderplatz, a paisagem passa dos estreitos corredores da massa construída, para as largas avenidas cercadas de conjuntos da década de sessenta e setenta, as grandes áreas calçadas e, chegando à Alex (como se dizia antigamente), as linhas de trem de superfície riscando o asfalto por todos os lados. Dois grandes volumes construídos: uma torre envidraçada e uma enorme loja de departamentos. Entrando na praça após passar por uma grande marquise que estranhamente é tomada por uma forte e constante rajada de vento, vejo diversos grupos de adolescentes sentados ao redor da fonte ou arriscando manobras de skate, pessoas circulando pelas beiradas, barracas de feirantes, outros três grandes volumes construídos, também ocupados com atividades comerciais, a estação do S-Bahn e uma linha de Tram que corta o espaço ao meio. Das fotografias e aquarelas antigas que vi, assim como do texto de Döblin, em Berlin Alexanderplatz ${ }^{116}$, só reconheço o grande movimento de pessoas atraídas pelo comércio e pela rede de transporte. Não consigo nem ao menos localizar onde ficava a grande loja de departamentos Hermann Tietz que aqui "reinava”"11. Seu prédio não foi atacado na Kristallnacht, pois a loja já havia sido expropriada, mas foi destruído com a guerra.

116. DÖBLIN, Alfred. Berlin Alexanderplatz. São Paulo, Martins Fontes, 2009 117. GEISEL, Eike. "Excluidos e delinquentes". In: Berlim, 1919-1933: a encarnação extrema da moderidade. Rio de Janeiro, Jorge Zahar, 1993, p.57. 
Atravesso o Rio Spree e a porção da ilha cuja extrema densidade fo arrasada nos bombardeios, sendo substituída no período socialista por grandes edifícios modernos e uma larga avenida de quatro pistas em cada sentido: um trajeto pouco agradável para um pedestre. Grandes edifícios corporativos, provavelmente construídos a partir da década de noventa, e um letreiro da Coca-Cola despontam lá na frente. Chegando mais perto, máquinas demolem uma construção mais antiga ao lado de altas fachadas espelhadas. Até onde o meu olho alcança a partir desse ponto, não vejo nenhum edifício que aparenta ter mais do que 50 anos. Os dois primeiros andares de um deles desenha uma curva para dentro do restante do prédio, formando uma marquise que abre os braços para a rua e levando a um jardim na parte de trás. Como as pedras que fazem o calçamento são as mesmas da calçada, insinuando uma continuidade da rua, aceito o convite e entro. Imediatamente após passar a área sombreada é possível ver uma centena de bancos de concreto de diferentes comprimentos formando três fileiras no gramado desse jardim cercado. Trata-se da Daniela. "Die de texto e às diferentes interpretações que constituem o Talmud, ao Synagoge
Lindenstraße". sinagoga construída no século XIX ${ }^{118}$ e incendiada na Kristallnach em 1938. A identidade dos bancos e a sua funcão, ou seja, a de servir de lugar para sentar, é rapidamente apreendida, pois, de fato, a sua forma não deixa muita margem para outras interpretações, o que é
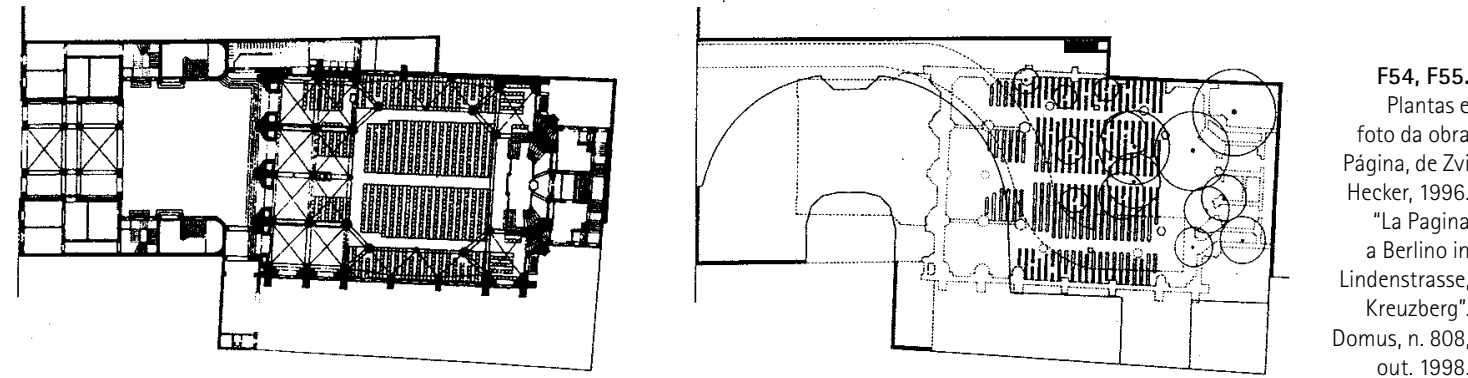

156 reforçado pelo fato de estarem implantados em um espaço identifiado como uma pequena praça. A grande quantidade de peças e disposição em fileiras, por sua vez, me leva de uma indagação com relação ao uso - "Haja gente para tanto banco!" - para a dedução de que aquela obra pretende representar um espaço religioso. Pela maneira como o passeio de pedras que circunda a construção atropela sinuosamente as fileiras que são assim interrompidas, fica também razoavelmente claro que se trata da sobreposição de uma construção nova e uma outra, cuja existência foi perdida. Todo o resto, entretanto, o fato de ser uma construção judaica, de ter sido destruída pela fúria antissemita, e, principalmente, a de fazer referência ao Talmud, exigem de mim entrar em contato com a publicação da obra em uma revista especializada ${ }^{119} \mathrm{e}$ ler o texto crítico que o acompanha. Sobretudo a referência à página impressa do Talmud - alusão que dá nome à obra - mostra-se bastante dependente da representação bidimensional da planta em escala reduzida, na qual é possível a comparação entre a distância dos bancos e o espaçamento entrelinha do texto. Um dos autores da intervenção, o arquiteto Zvi Hecker, participou do concurso do Memorial dos Judeus Assassinados com um projeto ${ }^{120}$ no qual retoma a referência ao Talmud, mas de maneira ainda mais dependente do discurso que o sustenta.

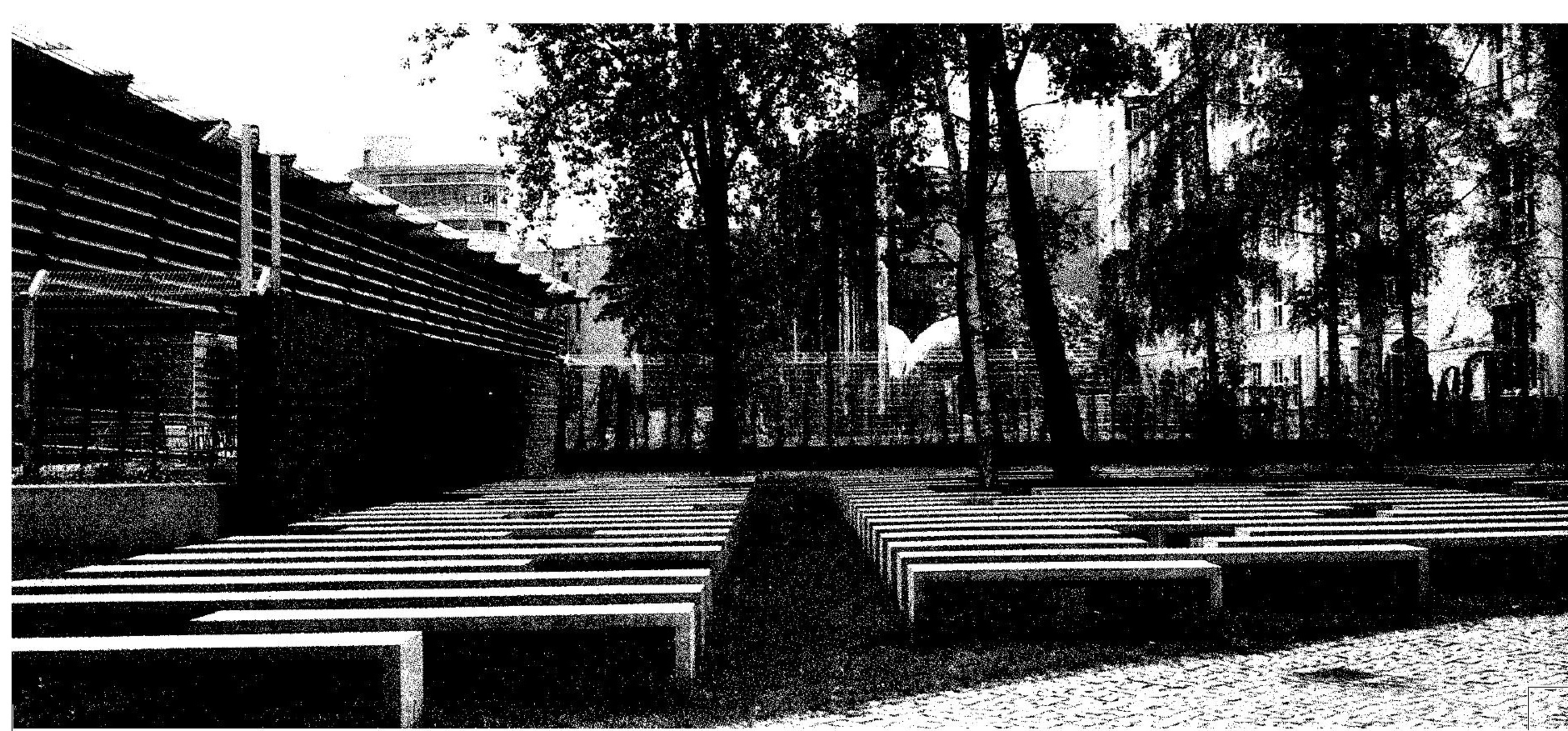




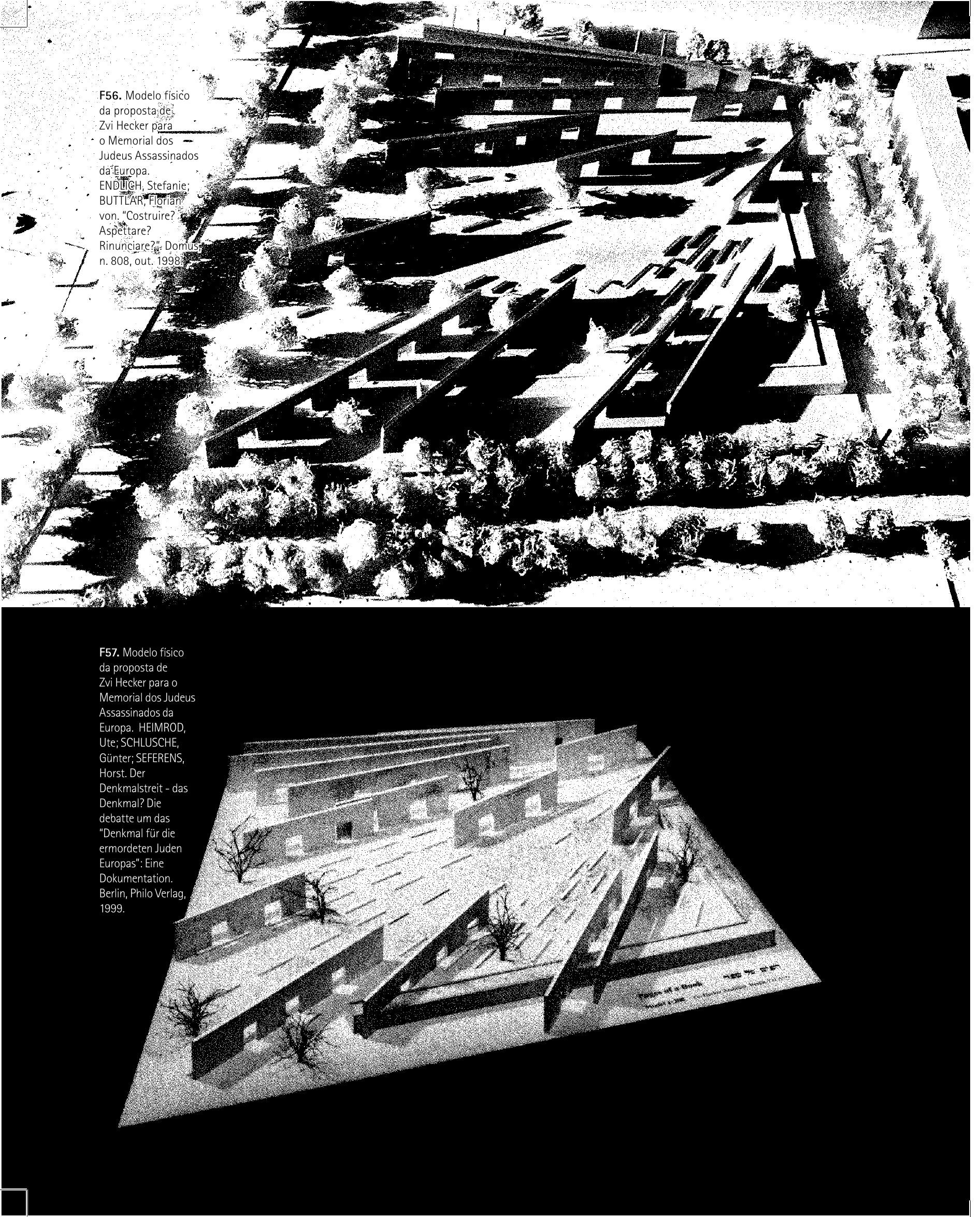

34. De volta à rua, um trecho bastante arborizado, se comparado com o Mitte, e com poucos estabelecimentos comerciais nos térreos dos edifícios corporativos e habitacionais - entrei na Berlim Ocidental - me leva ao Museu Judaico, cujo edifício foi projetado por Daniel Libeskind um ano após a queda do Muro. A sua forma colapsada, insinuando um violento movimento, sobretudo se analisada através das plantas e diagramas explicativos, tornou seu autor bastante conhecido em todo o mundo, não apenas entre seus colegas de profissão. Foi essa arquitetura, segundo diz o museu ${ }^{121}$, a principal responsável por uma inesperada popularidade nascida logo nos primeiros anos de funcionamento, atraindo um enorme público que visitava o edifício mesmo ainda sem nenhuma exposição montada dentro dele. Na proposta entregue por Libeskind - para esse museu, que foi objeto de um concurso de projetos -, o volume zigzag da nova construção é justificado por um composição formal que interpreta a sobreposição de uma obra de Walter Benjamin, Einbahnstrasse ${ }^{122}$, e uma ópera inacabada de Arnold Schoenberg, Moses und Aron. Intitulado de "Entre as linhas", o texto da proposta diz: “(...) duas linhas: uma linha reta, mas quebrada em fragmentos; a outra sinuosa, mas continuando ao infinito. Como as linhas se desenvolvem através deste 'dialeto' limitado-infinito, elas também se quebram - tornam-se desligadas - e mostram-se como separados, de modo que o vazio que corre centralmente atravessando o que é contínu materializa-se no exterior como ruina, ou melhor, como o resíduo sólido de uma estrutura independente (...)"123. Serpenteando entre as árvores que crescem no terreno, o volume é atravessado - algo que só se pode ver claramente através das plantas - por um volume imaginário em uma linha reta, formando seis torres de concreto que cortam o edifício verticalmente desde o subsolo até a

121. JÜDISCHES MUSEUM BERLIN. Disponivel em: <http://www.jmberlin.de/main/EN/04-About-TheMuseum/01-Architecture/00-architecture.php>. Acesso em: 15 dez. 2013.

122. "Rua de mão única" em uma tradução livre. 123. Tradução nossa. 
cobertura. Esses estreitos e altos espaços vazios não recebem qualquer conteúdo museológico, o que não significa que não possuem função no museu. Junto com o restante dos espaços, os corredores descontinuados, a fachada interrompida por diversos rasgos aparentemente aleatórios ${ }^{124}$, forma a representação de uma interpretação bastante particular da memória do Holocausto, feita pelo arquiteto Daniel Libeskind, afastando essa arquitetura dos espaços brancos e supostamente neutros, comumente pregados como adequados para um museu. Outro desses espaços, localizado do lado de fora da construção, é o chamado "Jardim do Exílio" que, muito mais do que todo o restante do museu, proporcionou a mim uma experiência em diálogo com aquilo sobre o que supostamente o espaço fala, nesse caso, o exílio. Curiosamente, essa rara sensação de desorientação não foi criada com a apoteose de ângulos, texturas, dimensões e luzes que marcam o edifício, mas com uma operação bastante simples de deslocamento. Os quarenta e nove blocos de concreto coroados com plantas que formam uma espécie de cobertura, são dispostos regularmente formando uma inclinação de noventa graus em relação ao piso. Mas como o conjunto todo possui uma inclinação de doze graus no sentido diagonal do quadrado, ao entrar nesse espaço senti o conflito entre meus olhos, que diziam estar tudo certo e em ordem, e o restante do meu corpo, que sentia lateralmente a força da gravidade. Saquei minha câmera para fazer uma fotografia e, ao procurar o enquadramento pelo pequeno visor, me vi tombando para o lado até encostar em um dos blocos. Poucos anos depois desse projeto, Libeskind também participou do concurso do Memorial dos Judeus Assassinados da Europa com uma proposta cujo resultado formal é bastante similar ao do Museu Judaico, embora a justificativa dada no texto que acompanhava o projeto apontasse para outras relações desenhadas aqui.

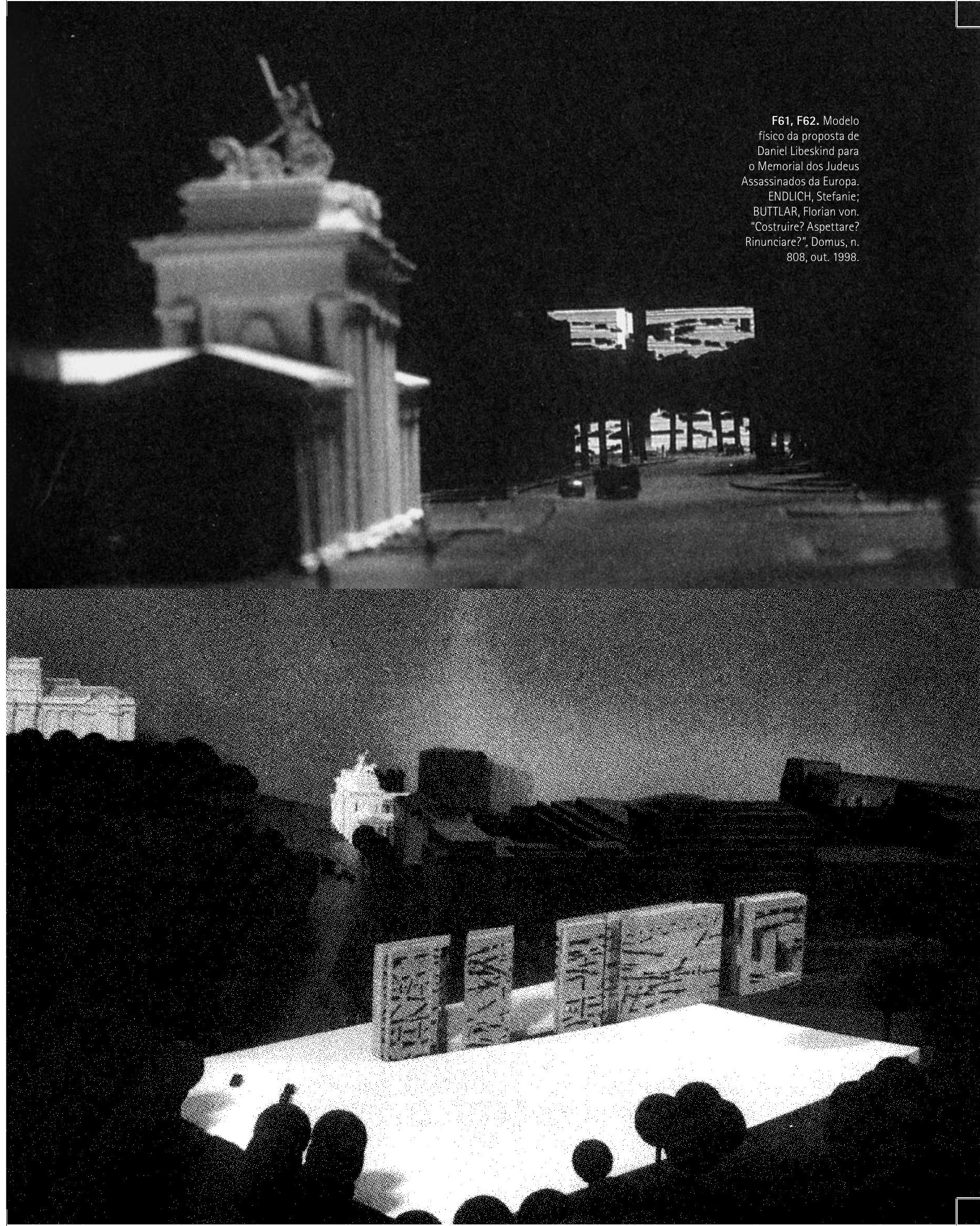


Depois de tropeçar em mais duas pedras - Max Laske, nascido em 1903, morto em 1942; Felix Bobek, nascido em 1898, morto em 1938 - chego ao local onde sobrou um trecho do muro que começou a ser derrubado no final do ano de 1989. Esse período não foi marcado apenas pela queda do muro, mas por uma série de iniciativas de revisão da história recente do país. Em 1985, ano marcado por eventos comemorativos relativos ao aniversário de quarenta ano do final da Segunda Guerra, Richard von Weizsäcker, presidente da Alemanha Ocidental, fez uma espécie de pedido oficial de perdão pelos crimes cometidos pela Alemanha. Nos anos seguintes também foram executadas diversas reparações financeiras às família das vítimas, que haviam sido expropriadas de seus bens durante 0 nazismo. Em 1987, nesse terreno atrás do muro que havia abrigado no passado a sede da Gestapo ${ }^{125}$, foi realizada uma exposição - entitulada de "Topografia do terror" e exposta em pavilhão temporário concebido por Jürg Steiner - contando cronologicamente a ascensão do nazismo e o Holocausto. A polêmica em torno da maneira como a história era contada foi o estopim da reunião de alguns cidadãos, entre eles, a figura central da jornalista Lea Rosh, dando origem à iniciativa que culminou na construção do Memorial dos Judeus Assassinados da Europa. 0 grupo se organizou e gradualmente conquistou apoio à proposta de construção de uma obra em memória dos judeus assassinados durante o regime nazista, proposta apresentada em agosto de $1988 \mathrm{em}$ um debate público. A iniciativa, entretanto, enfrentou sérias resistências por parte de políticos, acadêmicos artistas, que questionavam desde a ausência das outras vitimas - ciganos, homossexuais, etc. - na homenagem, até os problemas conceituais envolvidos com a ideia de monumento. É curioso notar o contexto no qual a proposta e o debate se deram. A Alemanha passava por um período de profundas transformações sociais, como iminente reunificacão e reconstrução da cidade, e, ao mesmo tempo, de lembrança e reflexão sobre a sua própria história. É notável nesse contexto a tensão entre a ideia de uma nova Alemanha, concretizada na reunificação do país e na reconstrução da cidade de Berlim, e a indigesta e massacrante presença da memória da guerra e do Holocausto, exposta diariamente nas ruínas espalhadas pela cidade, nos filmes e programas de TV, no conteúdo didático das escolas e no mal-estar que gerava nas diferentes gerações: as mais antigas, que viveram a guerra e que carregavam a culpa por uma relativa conivência com os horrores do nazismo, e as mais novas, que eram obrigadas a lidar com um passado que não lhes pertencia.

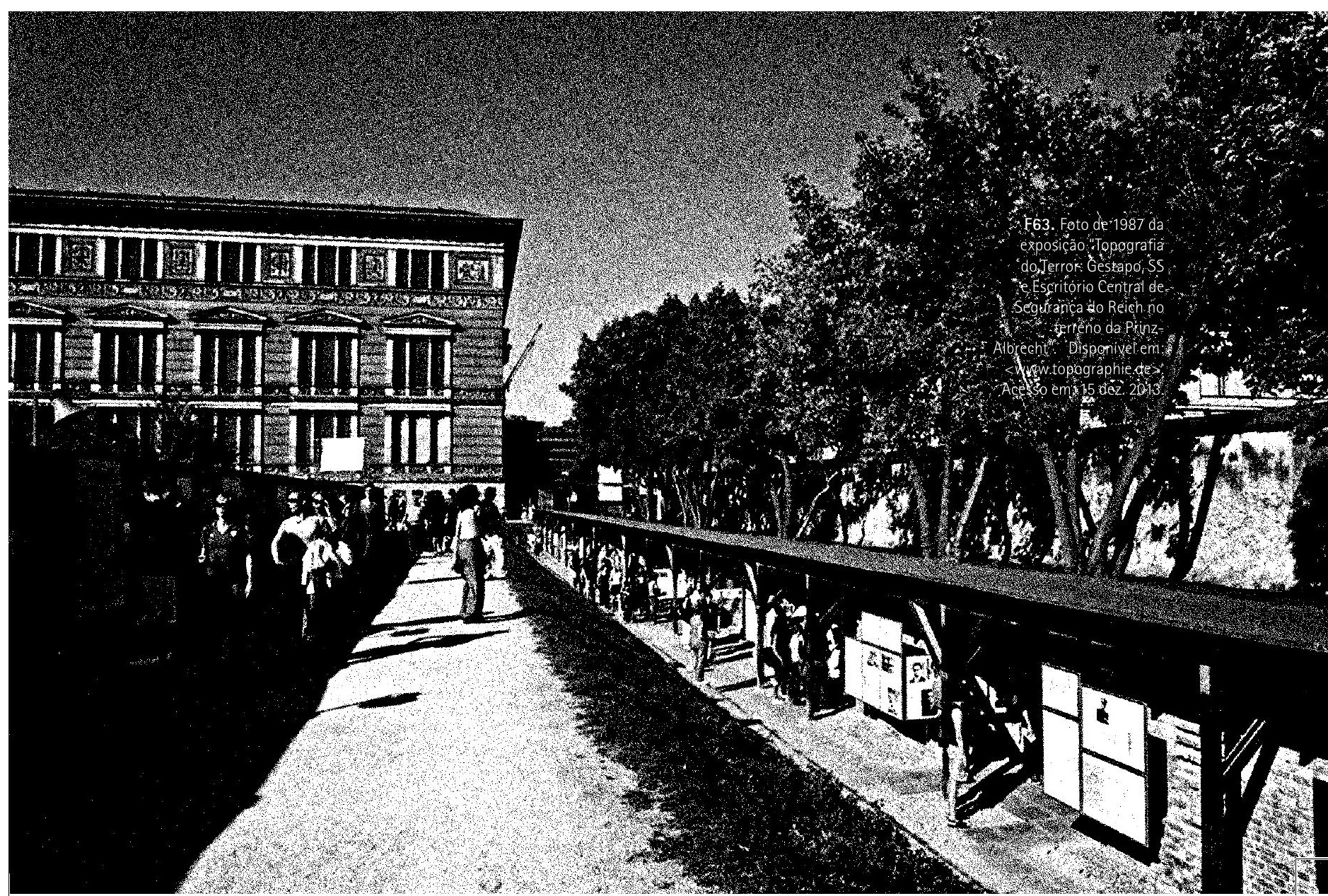


Seguindo pela Kochstraße e dobrando a esquina à esquerda, entro na Friedrichstraße, a importante rua comercial de Berlim que corta a cidade, desde a Torstraße, cujo nome vem do limite da cidade no século XVIII (a rua do portão), até outra entrada da cidade no limite sul, o Hallesches Tor, e que já era um eixo circulação no sentido norte-sul desde o final do século XVII. Passo em frente ao edifício-colagem projetado por Eisenman na década de oitenta, o sítio arqueológico fictício do IBA Social Housing e vejo pendurada em uma das fachadas uma grande bandeira da URSS desbotada e rasgada nas pontas. Acima da vitrine entulhada de cartões postais, camisetas e um cartaz que reproduz um grafitti ironizando o beijo fraternal entre Honecker e Brezhnev, os letreiros anunciam em caixa alta: "MUSEUM CHECKPOINT CHARLIE"; "HAUS AM CHECKPOINT CHARLIE"; "MAUERSHOP IM MAUERMUSEUM". Lá dentro é possível ver objetos da vida cotidiana da época, veículos antigos, placas de trânsito do setor americano e do setor russo e centenas de fotos. Me vejo cercado por uma multidão de pessoas falando as mais diversas línguas. Um ônibus estaciona e dele saem outras cinquenta que se apressam em vistoriar as lojas de souvenir com as quais eu ainda não havia topado. Por falta de espaço em alguns pontos da calçada, elas ocupam e atravessam a rua munidos de suas câmera e smartphones fotografando tudo nos mínimos detalhes: as vitrines, as fachadas, as bandeiras dos Aliados, a cabine de controle onde dois atores se fantasiam de soldados dos EUA e da RDA. Vieram aqui para ver a Guerra Fria, para ver a Berlim dividida. Seguindo em frente tudo volta ao normal. Estou novamente em Berlim no ano de 2012 e caminho sozinho na tranquila e longa rua.
37. Ela veio para cá pela primeira vez no inverno passado e não conseguiu desvincular a experiência da sua visita da memória do Holocausto. Já achava justa essa percepção (se é que cabe algum julgamento para isso), tendo em vista a proximidade da tragédia com a sua história familiar. Mas agora a entendo um pouco melhor. Berlim parece pedir o tempo todo perdão pelos seus pecados, pedido que, no entanto, se manifesta quase sempre em tom de nota oficial a imprensa ou, quando claramente promovida por judeus, em tom de confissão de culpa ou de penitência.

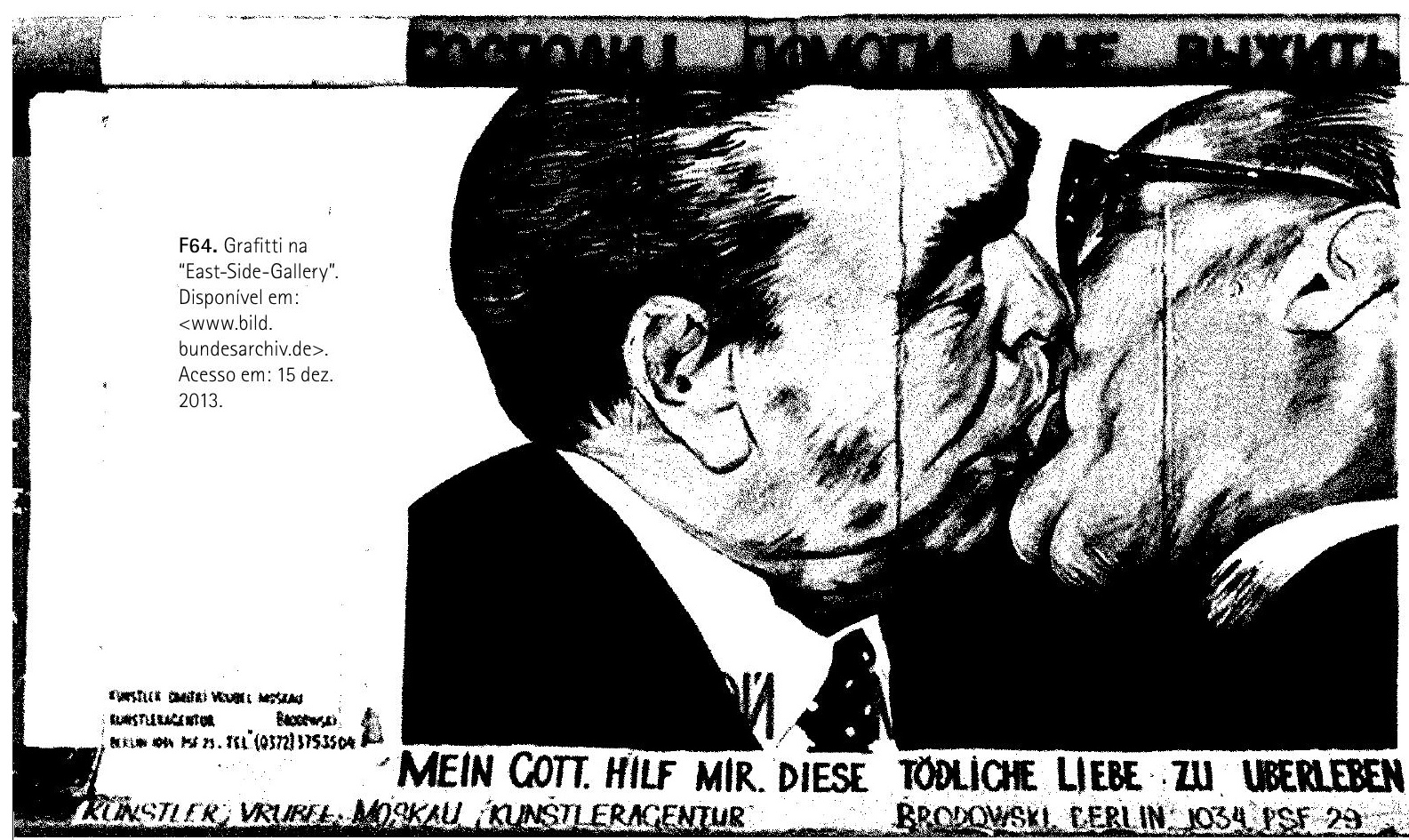

$x=$ 
A memória da guerra e da perseguição e extermínio dos judeus está por toda parte, recorrentemente dita com todas as letras como na placa da Nova Sinagoga - "Esta sinagoga de 100 anos foi incendiada pelos nazistas em 09 de novembro de 1938 no Kirstallnacht. Durante a Segunda Guerra Mundial (1939-1945), foi destruida por um bombardeio no ano de 1943. A fachada da Casa de Deus deve ser um aviso e um lembrete para todos os tempos. NUNCA SE ESOUECA DISSO. Comunidade Judaica da Grande Berlim, Setembro 26. Tradução de $1966^{M_{126}}$-, com apenas algumas delas ostensivamente colocadas na frente da casas, como nas Stolpersteine, ou no dito hermetismo dos monólitos do Memorial dos Judeus Assassinados da Europa. Mas não está apenas nos museus, placas de bronze, memoriais blocos nas calçadas, onde correntemente é funcionalizada como "um lembrete" de que os horrores de fato ocorreram, ou "um aviso" de que podem ocorrer novamente, mas também na forma urbana nos lotes vagos, construções abandonadas, semáforos de pedestres (com um estranho pictograma na Berlim Oriental), no modo de vida econômico dos seus habitantes, na reiterada afirmação em folhetos turísticos e guias de viagem de que "Berlim é uma cidade marcada pela tolerância”. Tudo, de uma forma ou de outra, faz lembrar guerra. Tudo lembra o Holocausto.
39. Parece que com a reunificação da Alemanha foi feita uma tentativa de padronizar os sinais de trânsito, tentativa que foi frustrada pela contrariedade dos habitantes do lado oriental, apegados ao curioso boneco de chapéu, e pela preocupação com a memória do país. A diferença entre os sinais de trânsito entre o ocidente e o oriente recebeu, então, uma espécie de tombamento. Assim, os faróis de pedestre daqui, além de dizer se é ou não a hora de atravessar a rua, servem para indicar em que hemisfério estaríamos se estivéssemos em algum ano entre 1961 e 1989. De acordo com esse à minha frente, eu estaria em Berlim Oriental e neste momento posso atravessar a rua, desde que não demore muito, tendo talvez que dar uma pequena corrida, pois, dentro de poucos segundos não será mais permitido

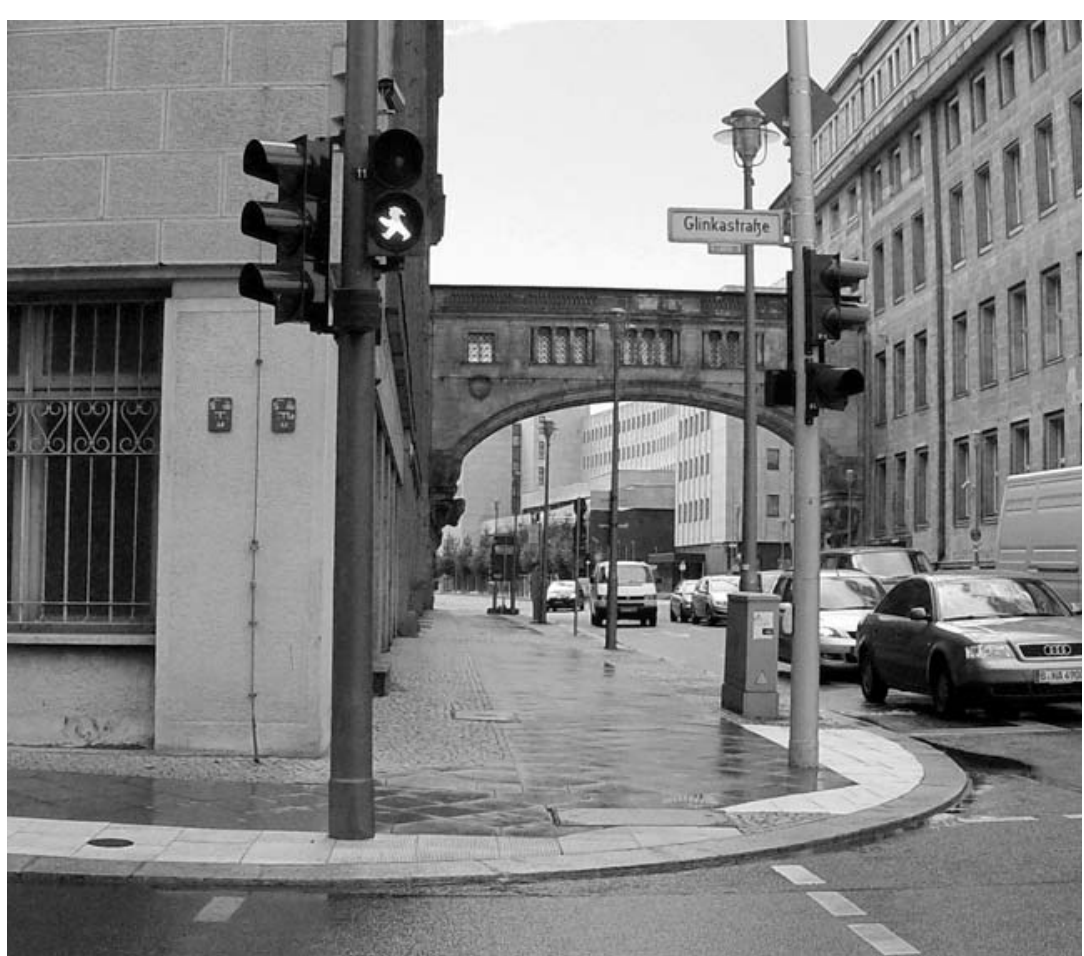


40. A partir da passarela que liga aqueles dois

prédios no cruzamento com a Mauer Straße - que,

segundo vi nos mapas antigos, tem esse nome por ser o
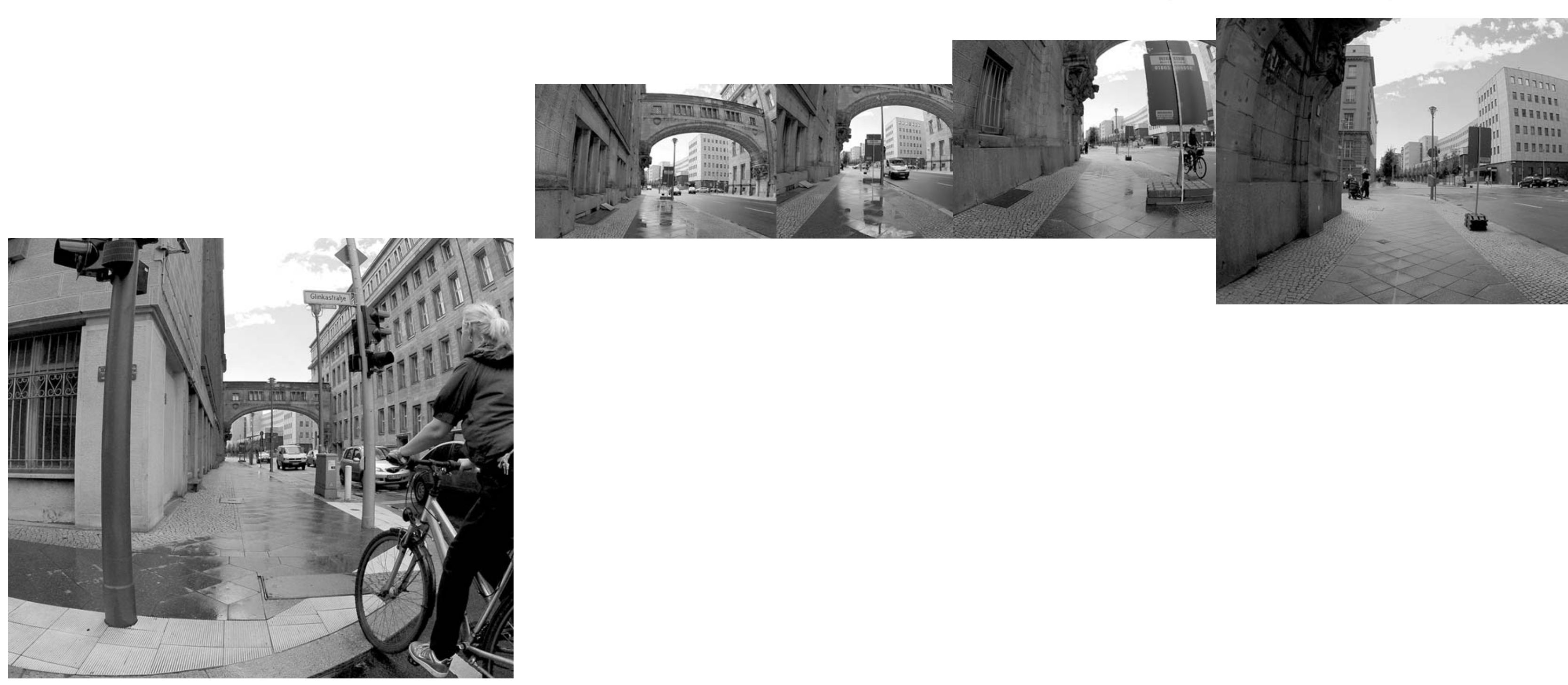
limite da cidade no século XVIII - a espacialidade da rua muda de maneira

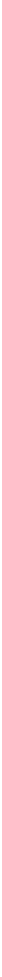


residencial, pequenos comércios: lanchonete, mercadinho, aluguel de bicicletas, loja

aparecer, organizadas em um renque que ocupa todo o térreo de um edifício

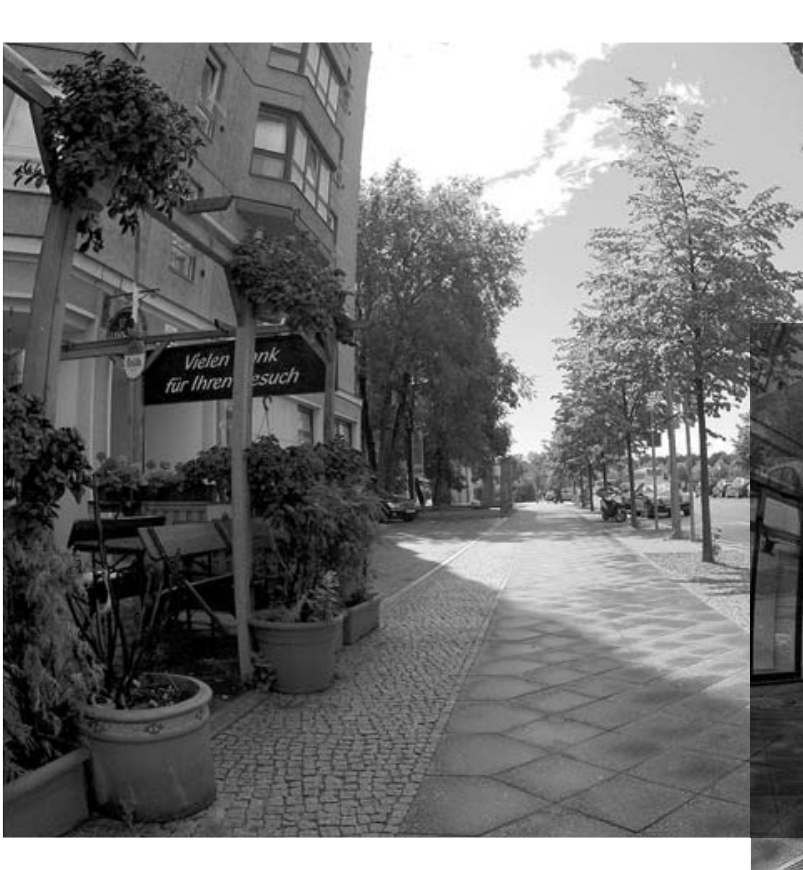

\%
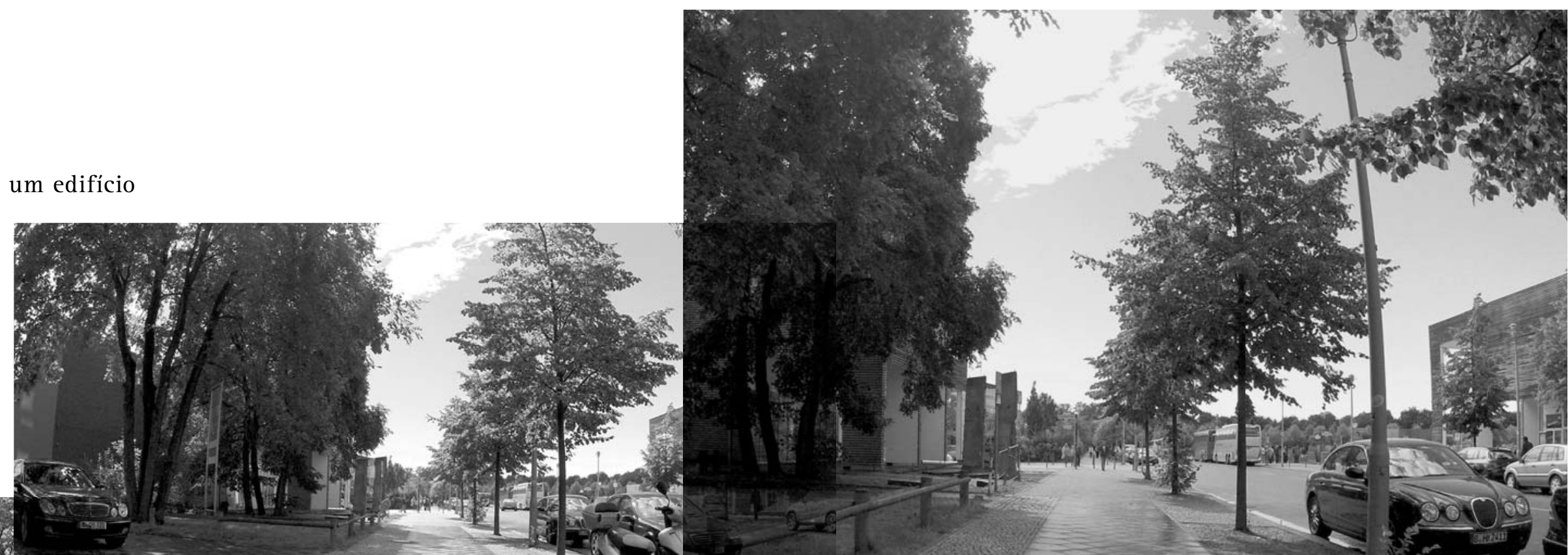

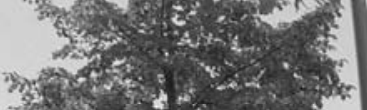

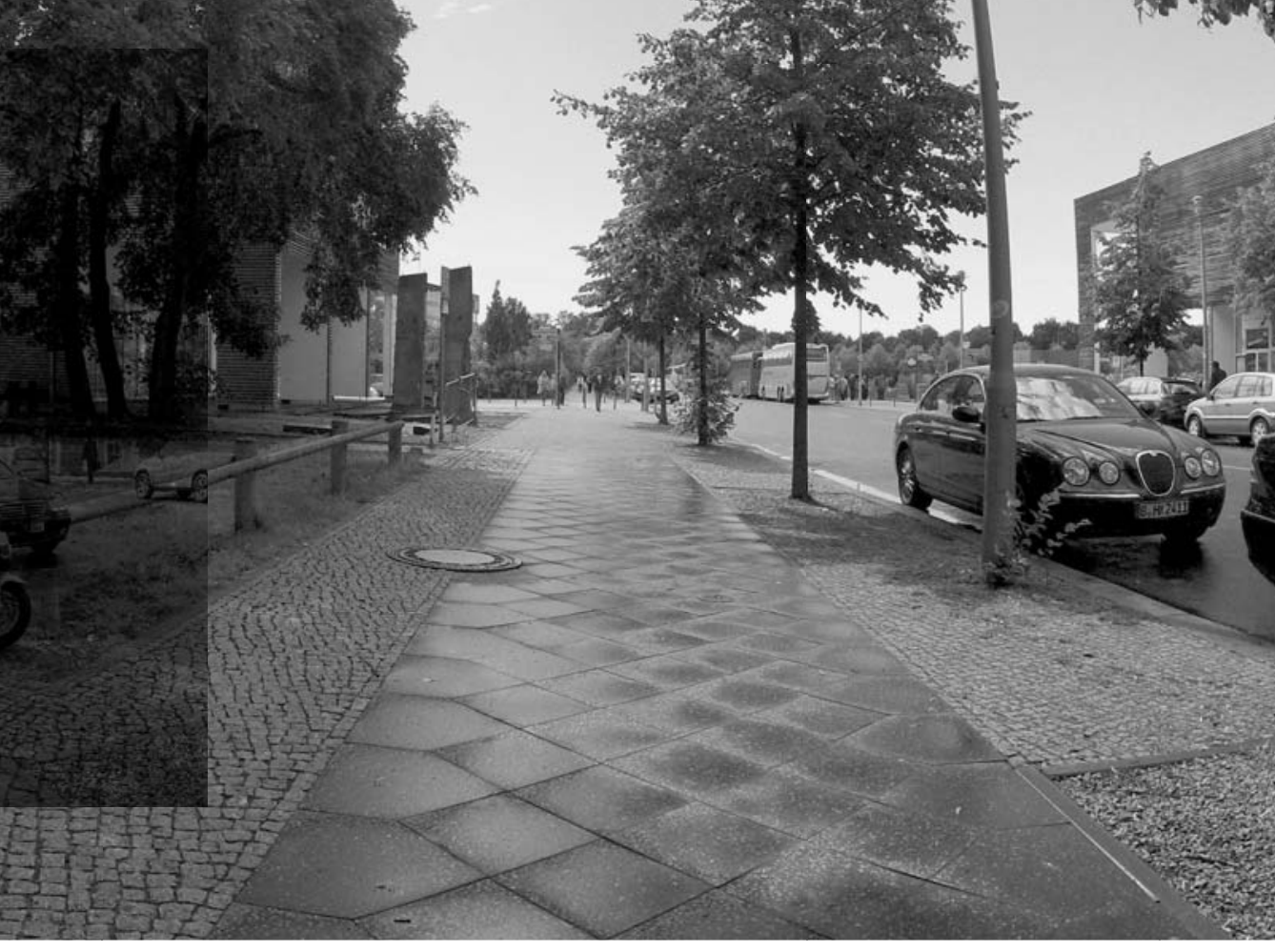


TERCEIRO CAPÍTULO NO MEMORIAL

de souvenires, indicando o movimento de turistas. Estou chegando.

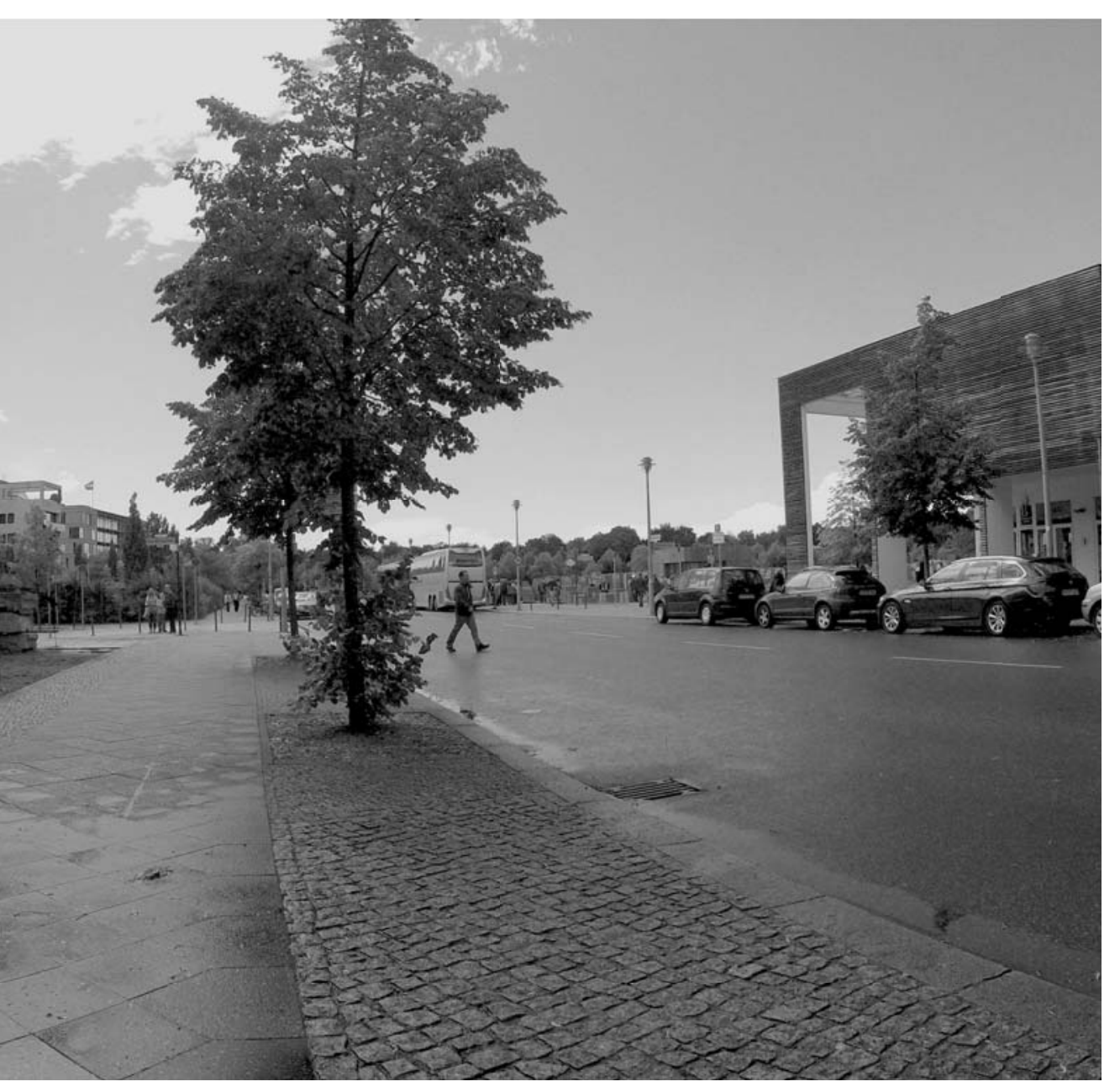


41. Já consigo ver mais à frente, pela ausência de edifícios e pela visão do topo da massa arbórea do Tiergarten, o final dessa área da cidade, a borda do bairro. À medida que caminho e me aproximo do Memorial, que, assim como as árvores do parque, já desponta anunciado por uma estreita faixa horizontal acima do nível da rua, afastam-se os edifícios e encerra-se o corredor da rua, que vejo sendo interrompido pelo parque. A rua não conduz apenas veículos e pedestres, mas também a luz, os ventos e os olhares que, com o rompimento dessa represa, ganha agora a possibilidade de fuga, de transbordo. Meus olhos não esbarram mais no alinhamento dos edifícios e passam a poder passear livremente pela ampla área que se abriu à minha frente.

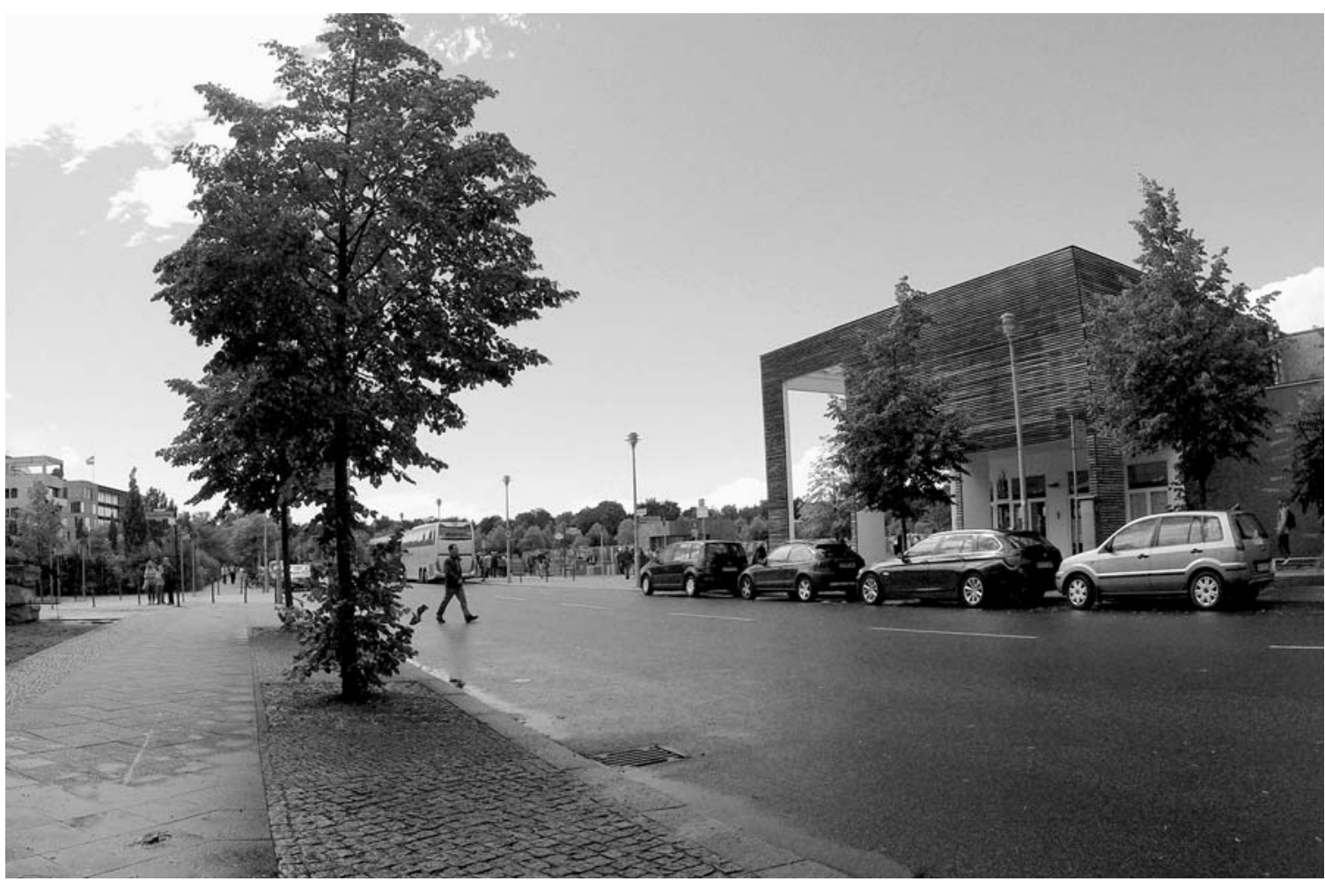


Assim permaneceu até a sua escolha como o local que iria receber o Memorial dos Judeus Assassinados da Europa. Nem mesmo no delirante projeto nazista para a reforma de

Mas a condição de vazio foi rapidamente devolvida poucos anos depois com os bombardeios e a demolição de quase todas as construções desse quarteirão que reunia o centro de poder nazista. Em 1961, com a construção do muro passando pela Ebertstraße (mais uma reincidência de muralhas), apenas uma ruína não foi demolida - colada à Pariser Platz e fora do terreno -, deixando a área completamente vazia em uma de zona de segurança do lado oriental da cidade, a chamada "death strip"

127. STIFTUNG DENKMAL FÜR DIE ERMORDETEN JUDEN EUROPAS. Materials on the Memorial to Verlag, 2005, p.18

5.6.

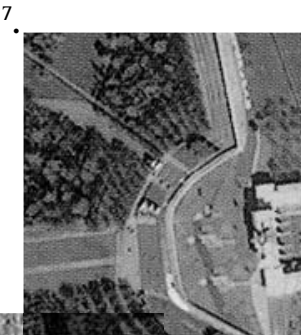

\author{
.
} Berlim, feito por Albert Speer a mando de Hitler, no qual a cidade teria áreas gigantescas demolidas e reocupadas com novas e grandiosas construções, a área do Memorial era afetada, mantendo-se como o jardim dos palacetes da Wilhelmstraße.

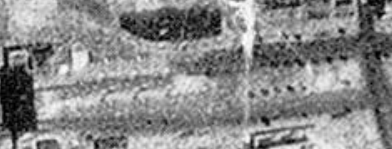
15. 15. 9. . (1) sing Sints 19: (10)

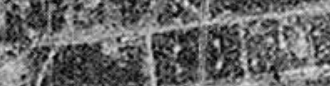
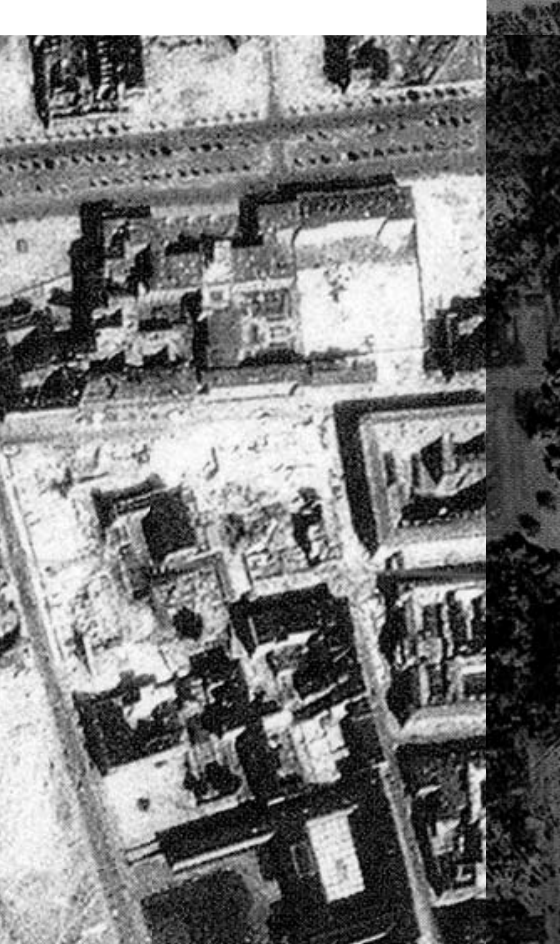

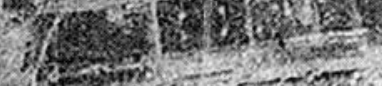
.

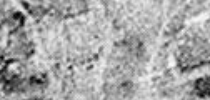

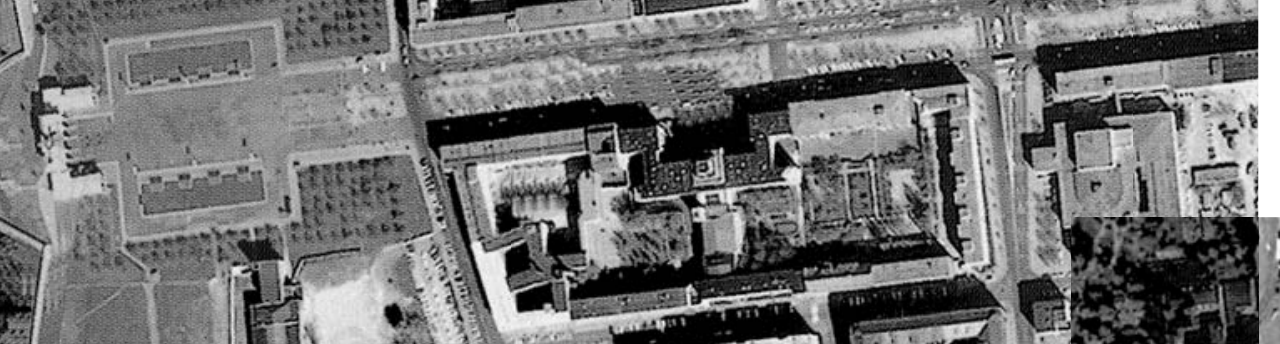

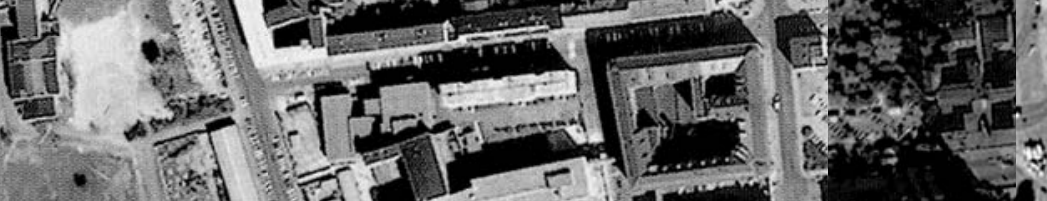

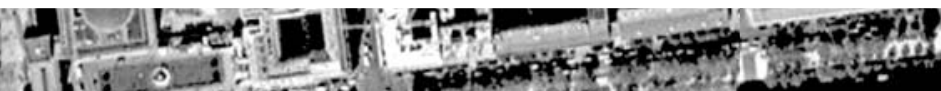
1460 n $27=-\sqrt{1-x i t}-50$

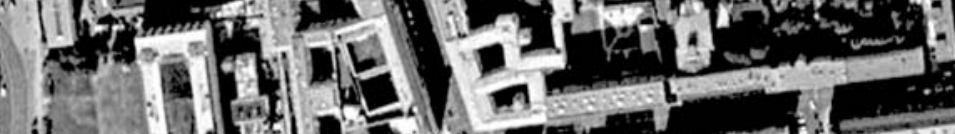
- 1 M

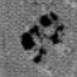
(T)

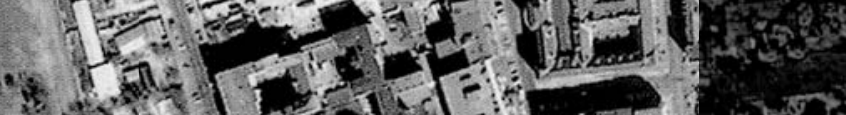

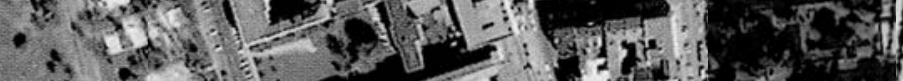
- $a^{2}-L^{2}+5=$ - $127 \mathrm{r}$

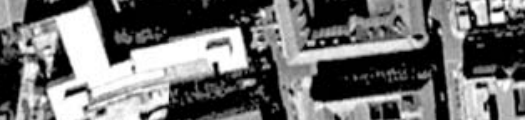
$+20-42$ 4. $+\frac{1}{2}$ 
43.

Não há qualquer utilidade para a minha análise afırmar categoricamente que há a incorporação de uma consciência da história desse sítio no trabalho de Eisenman, algo que contrariaria a natureza puramente hipotética do resultado de uma simples dedução. Além do mais, me interessa muito mais construir uma análise que não procure explicar a obra, mas sim criar movimentos análogos à minha experiência nela, sempre atento à potencial falibilidade de qualquer hipótese em confronto com a abertura de uma realização como essa. De toda forma, não há como não se lembrar das diversas fotocópias de mapas antigos, encontradas entre os desenhos e diagramas preliminares do projeto do Memorial no acervo do Canadian Centre for Architecture, mostrando a cidade de Berlim em diversas etapas de desenvolvimento com algumas anotações feitas com marcador vermelho. Sobre uma delas, uma anotação feita em um pedaço de papel rosa a ela colada indica que o materia foi herdado do projeto de 1982 para a mesma cidade, o IBA Socia Housing, no qual a incorporação da história do sítio - feita, entretanto, como uma colagem descontextualizada da antiga muralha, do Muro de Berlim e da malha urbana da cidade - é não só evidente, como também declarada. A pesquisa feita em 1982, assim como alguns fragmentos do raciocínio feito naquele projeto, teriam sido resgatados e retrabalhados no projeto do Memorial. Mera hipótese que encontra grande dificuldade de ser testada, não apenas pela escassez de indícios mais evidentes à observação, como também pela recusa, amplamente declarada nos textos e nas diversas falas de Eisenman, de uma representação simbólica.

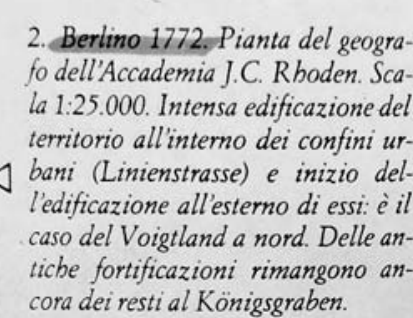

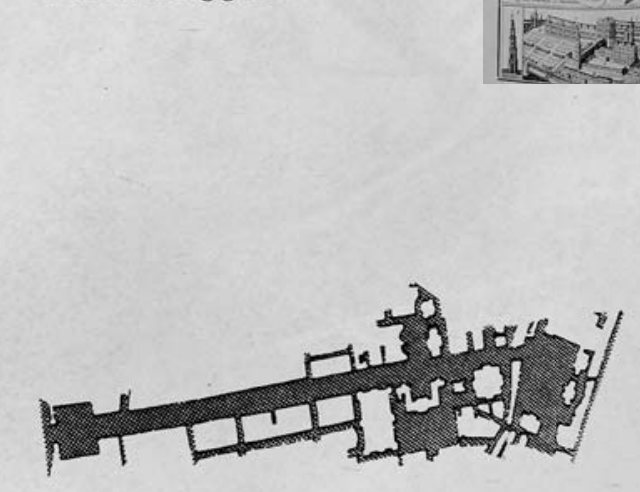

$X$

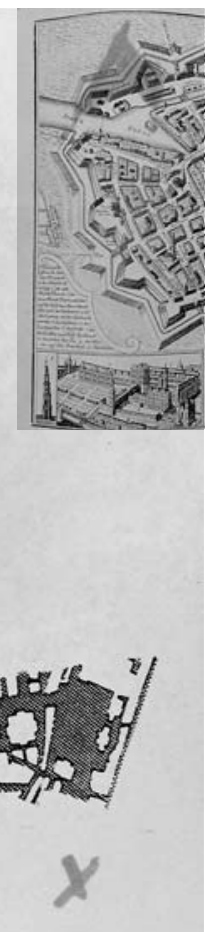

190
F73. Reproduçōes de mapas e anotaçōes
do materia de projeto do Memorial dos Judeus Assassinados da Europa. Acervo
CCA. Foto: Georgia Lobo
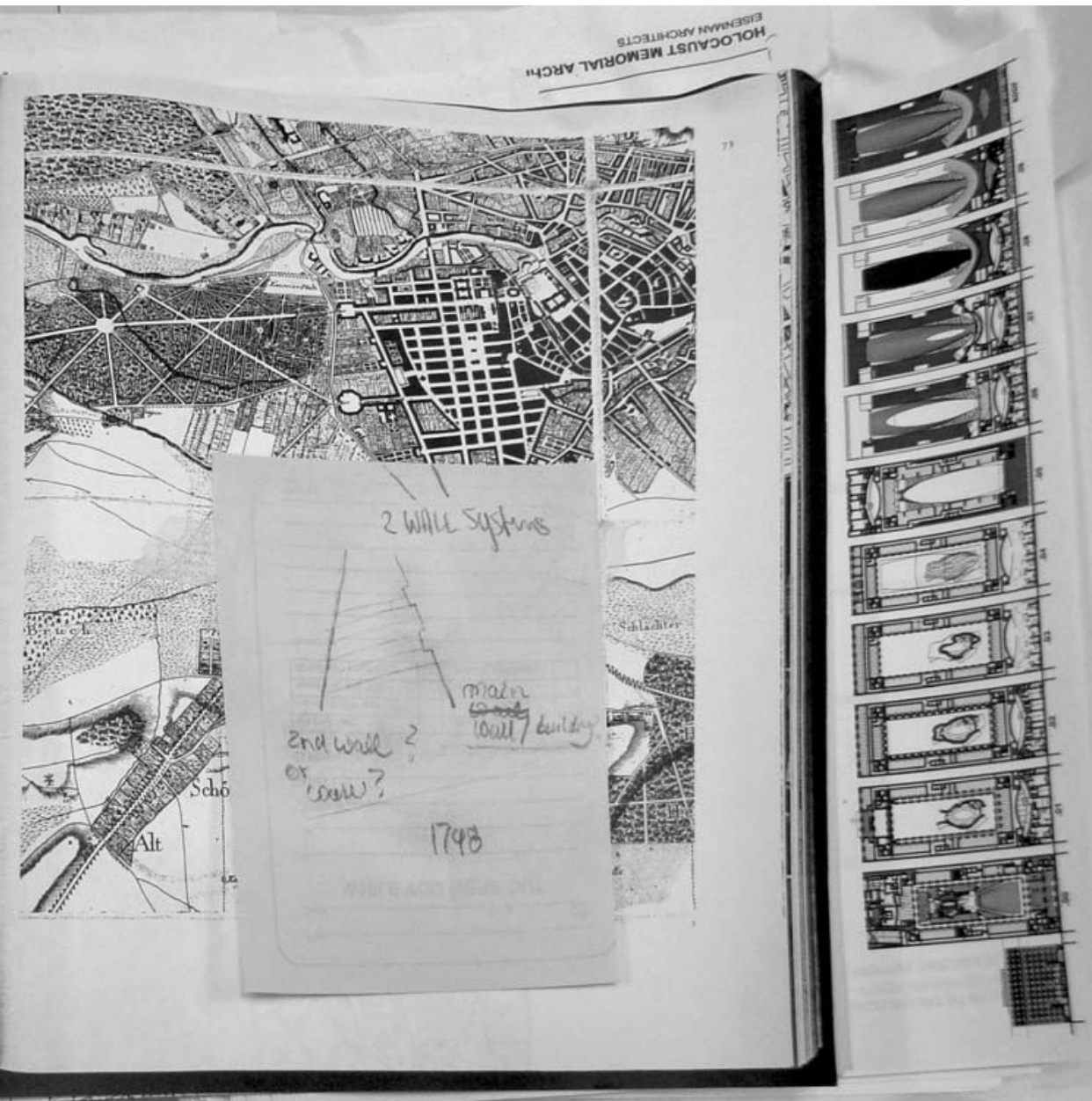
Agora mais de perto, tenho uma visão melhor do conjunto. Cora Berliner Straße com Hannah Arendt Straße. Esse, sem dúvida, é o lado mais movimentado do Memorial, pois logo ali ao lado, bem próxima à calçada da Cora Berliner Straße, está a escadaria de acesso ao Centro de Informações, uma construção subterrânea semelhante aos inúmeros bunkers que foram construídos nessa antiga quadra durante a Segunda Guerra e que abriga um conteúdo museológico: uma exposição permanente e dois bancos de dados de vítimas do Holocausto, o do Arquivo Federal e o do Yad Vashem. Com a escolha da proposta de Eisenman e Serra e o desenrolar do processo, foram demandas por parte do Governo alemão (o cliente da encomenda) algumas mudanças e adaptações no projeto original, evento ao qual é usualmente creditado o fim da parceria com Richard Serra.
Além da criação de uma faixa reservada ao passeio de pedestres no perímetro do lote, a principal alteração e que gerou a mais significativa transformação conceitual da proposta foi a exigência de criação do Centro de Informações. Assim, a demanda colocada foi a de esclarecimento da finalidade daquele memorial através de uma estrutura que, ao contrário da suposta mudez e hermetismo do campo de pedras, conseguisse expor a história do Holocausto.

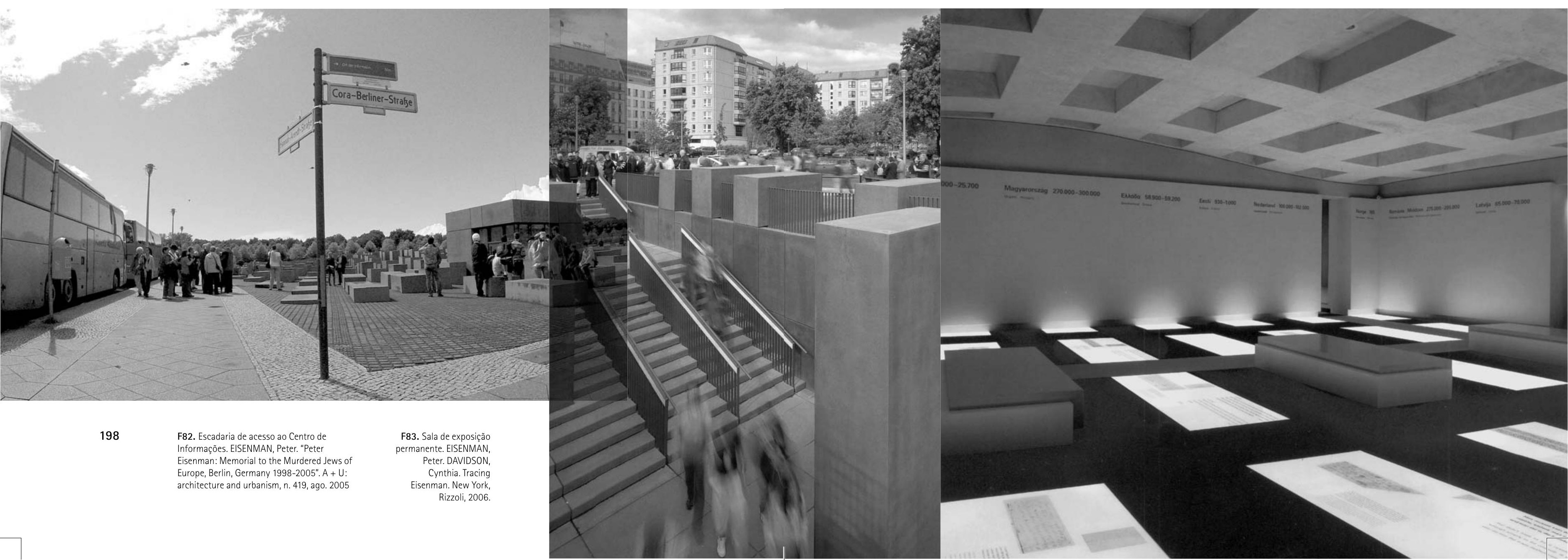


Dessa operação, como observou o filósofo Giorgio Agamben em um pequeno texto crítico publicado no Die Zeit ${ }^{133}$, resultou uma dualidade entre o campo de blocos mudos e o pequeno museu que narra didaticamente uma cronologia de acontecimentos: uma dualidade entre dois tipos de memória. Eisenman, que não o queria como parte da obra, mas, ao contrário de Richard Serra, aceitou incorporá-lo, chegou a estuda uma implantação na aresta oposta do polígono que, coincidentemente ou não, foi o único ponto de toda essa área dos antigos "Jardins do Ministério", até o momento de construção do Memorial, a receber uma edificação de grande porte: as instalações e o bunker de Goebbels.

133. AGAMBEN, Giorgio. Die zwei Gedächtnisse. Die Zeit, Hamburg, n.19, 04 ago, 2005.

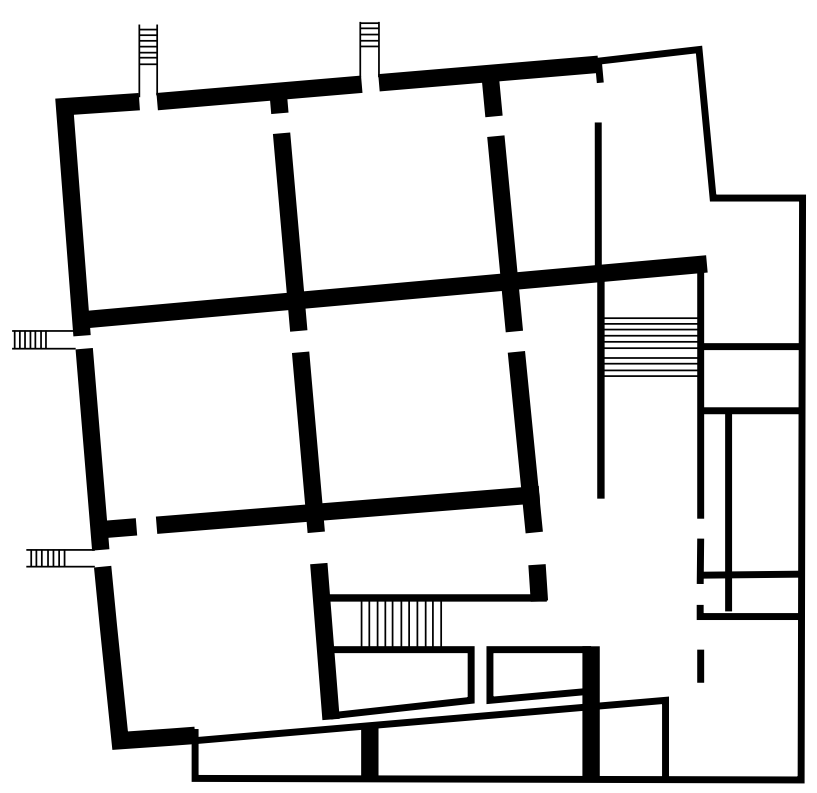

0 curioso desse processo, mesmo com a implantacão nessa esquina não na oposta, onde ficava o bunker é que as duas únicas grandes construções funcionais feitas aqui até hoje - já que o Memorial em s não exatamente possui uma função que não aquela pouco definivel e palpável que a nomeia, a de fazer lembrar - sejam a do Centro de Informações, com sua exposição didática, e as instalações do responsável pela fantástica máquina de propaganda nazista.

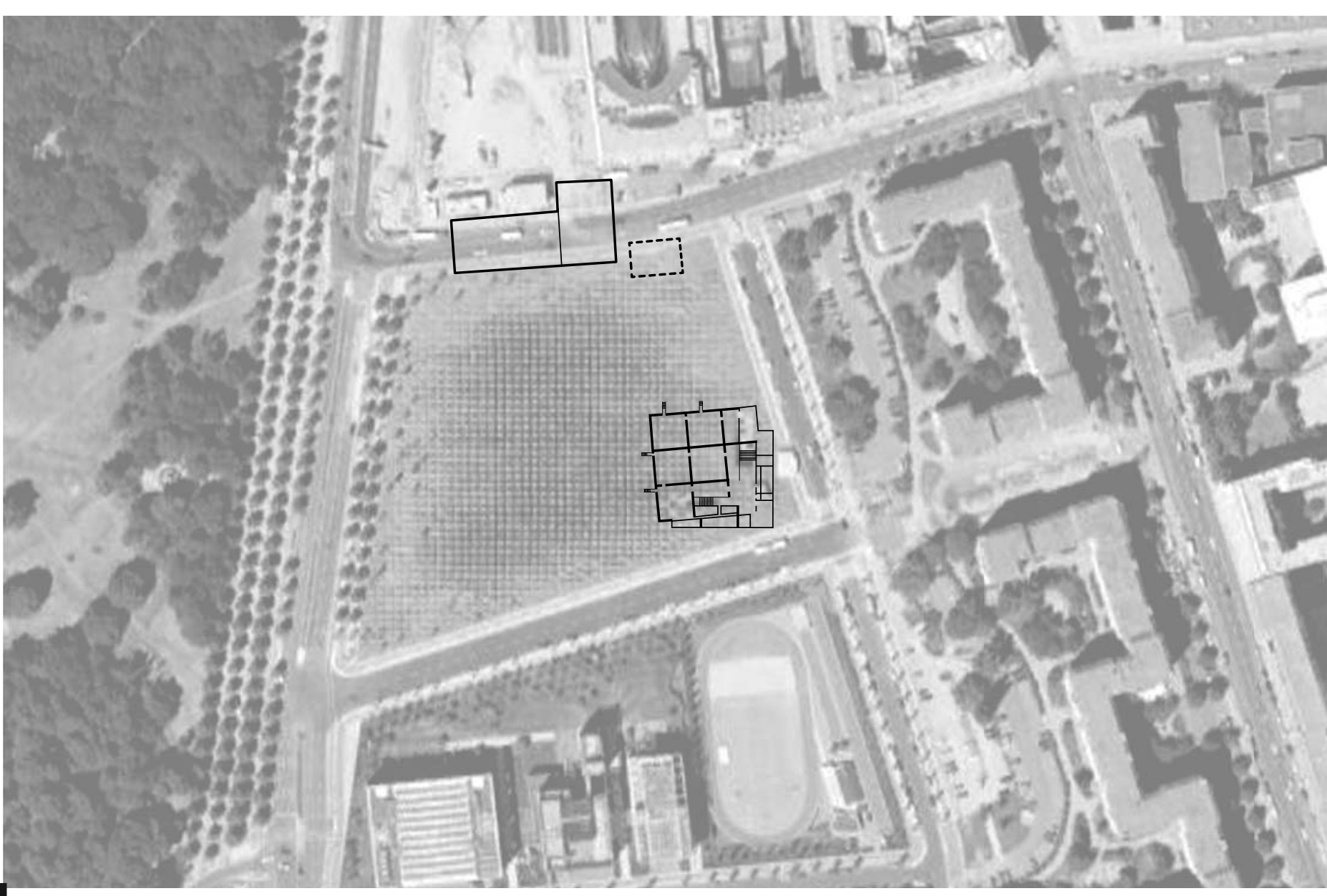


A exigência por alterações colocada pelas autoridades gerou ainda outra associação também curiosa e completamente acidental entre uma característica muito específica da obra, o número de pedras, e o Talmude.
"O número de pilares no meu projeto original era de 4350, o suficiente para preencher o terreno. Mas o Chanceler Kohl notou que algum espaço teria que ser deixado para as calçadas, além de vários outros problemas práticos, o que reduziu o número para 3000. Em seguida, a embaixada americana [de frente para o Memorial] disse que a calçada teria que ser deslocada por razões de segurança, o que reduziu o número ainda mais para 2711: um número sem significado além do que o de preencher o espaço dado a nós. Mas um dia um jovem estudante rabinico veio até mim e me perguntou se eu havia percebido que o Talmude moderno tem duas mil setecentas e onze páginas. Então talvez, depois de tudo, isso tenha algum significado...". ${ }^{134}$

134. EISENMAN, Peter. "Memorial to the murdered Jews of Europe". The Leo Baeck Memorial Lecture,
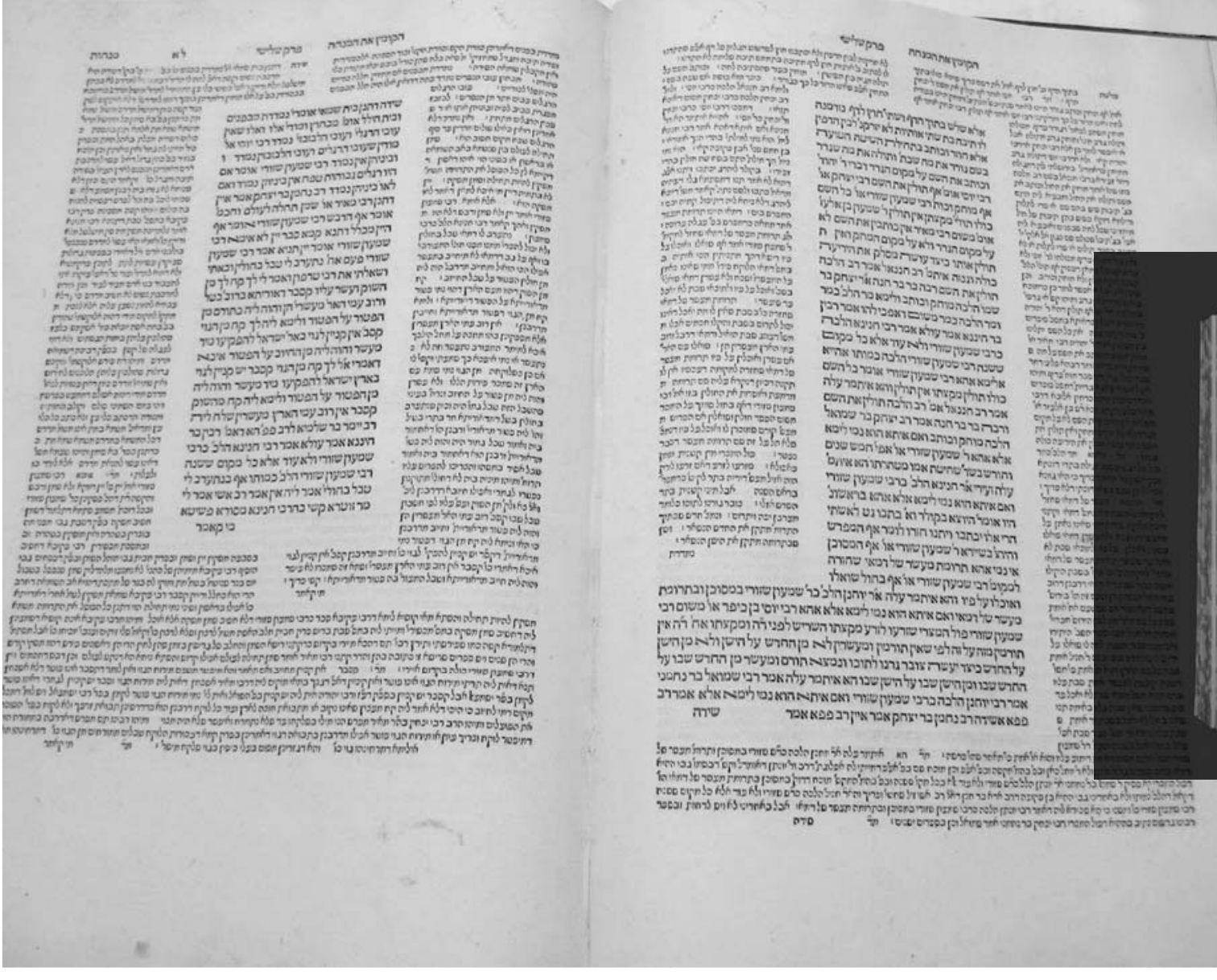

202
F84, F85. Páainas do Talmud.
Disponivel em:< <blog.y.u.edu>. Acesso em: 05 jan. 2014.

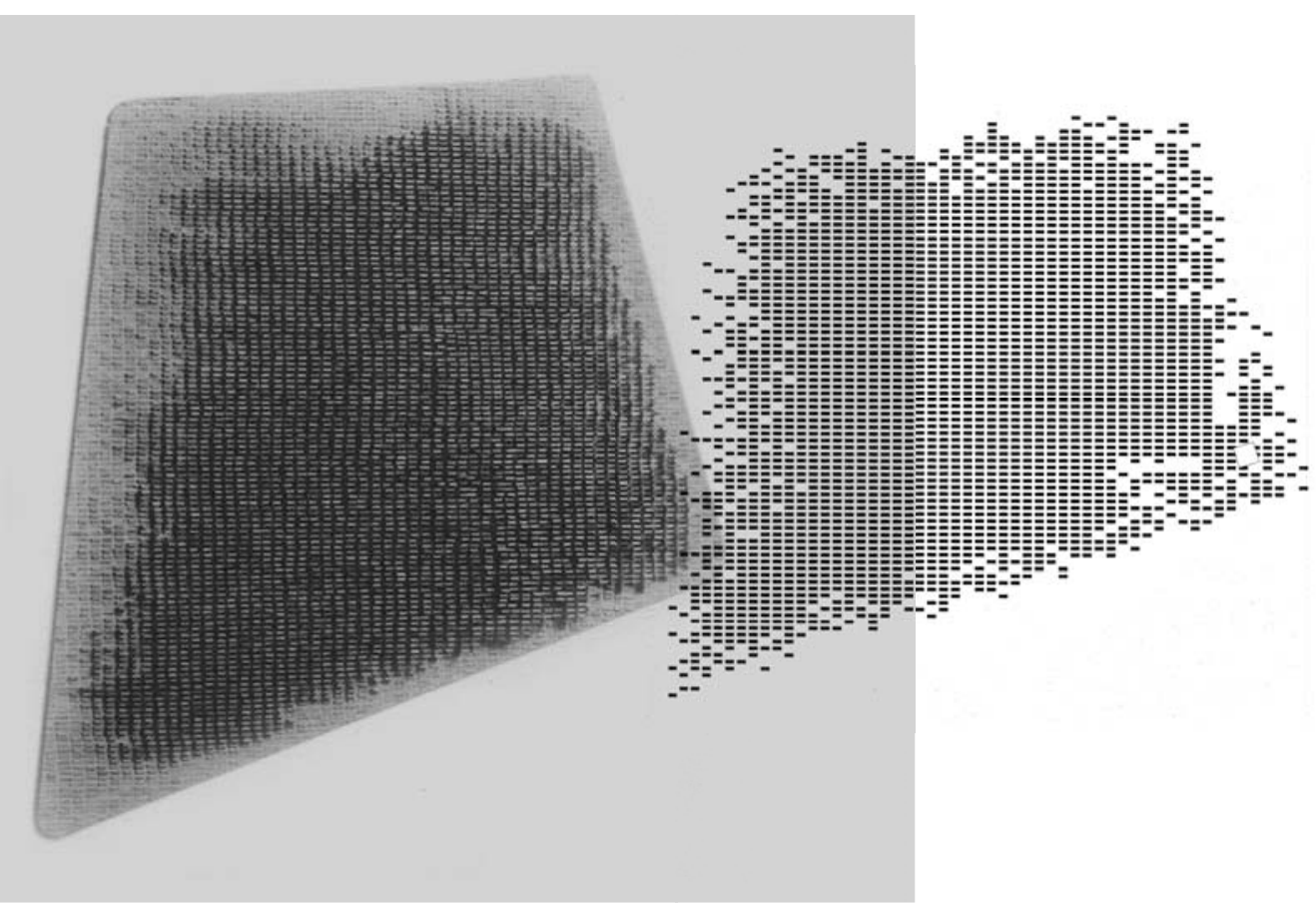

F86. Modelo fisico da proposta de Eisenman e Serra. $\quad$ F87. Mapa dos monólitos. BINET, Helène; RAUTERBERG, Hanno; WASSMANN, Lukas. Holoccaust Memorial Berlin. Baden, Lars Müller Publishers, 2005.
203 
0 calçamento de mosaico de pedras que reveste quase todas as calçadas por onde passei, desde o apartamento até essa esquina, invade a Cora Berliner Straße para indicar a preferência aos pedestres. Atravesso a rua sem olhar para os lados, ansioso para me aproximar mais da obra. 0 calçamento esticado sobre a rua, prosseguindo ao longo da margem do Memorial, indica uma continuidade do passeio público que parece tentar amenizar o contraste entre a cidade e a obra. De fato, a maneira pouco tênue com que o campo de monólitos era implantado na primeira versão do projeto foi motivo de uma polêmica que gerou a exigência de se manter livre o espaço para uma calçada comum, além de se promover um rebaixamento das pedras das margens.
0 assentamento das pequenas pedras do mosaico e das placas quadradas que formam o passeio, assim como em qualquer outra calçada - por que haveria de ser diferente? -, segue estritamente o desenho rua. Mais à frente, encontram de maneira brusca o pavimento de ladrilhos quadrados do piso do Memorial, um encontro conflituoso não apenas pela diferença entre os materiais - o granito de forma e cor irregular da calçada e o monocromático ladrilho de concreto preto -, mas também, e principalmente, pela orientação dos ladrilhos que acompanham os monólitos rigorosamente no sentido Norte-Sul, revelando com essa abstrata referência cartográfica, que a rua faz um desenho no sentido diagonal dos mapas que descrevem a superfície do Planeta Terra. 0 que seria mais arbitrário? Orientar a obra em função dos polos geográficos do planeta ou alinhá-la à rua que foi traçada seguindo princípios desconhecidos? A calçada se estende por todo o perímetro, restando à obra permanecer ilhada dentro dos limites virtuais do que poderia ser chamado de lote.

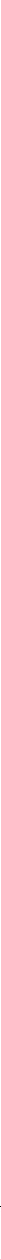


As árvores que eram previstas para circundar o terreno do Memoria no plano de desenvolvimento de toda a área ${ }^{135}$ - e que estavam presentes em algumas das propostas enviadas ao segundo concurso de projetos, como as de Zvi Hecker (o autor da obra "Página", por que passei ao cruzar o rio), Dani Karavan e Hans Hollein - não foram incorporadas no projeto de Eisenman e Serra (ou, ao menos, não representada no modelo físico), mantendo assim livre a vista para o conjunto, condição mantida na última versão do projeto. Apenas na margem Oeste, junto ao Tiergarten, algumas árvores foram plantadas no alinhamento da calçada, junto com outras dispostas irregularmente entre os monólitos, estabelecendo uma espécie de transição entre o parque e o Memorial. A possibilidade de apreensão da obra como um conjunto isolado foi motivo de questionamentos por parte da crítica que apontou uma relação com a ideia de monumento do século XIX ou com a concepção tradicional de escultura com a qual modernismo havia rompido ${ }^{136}$ a de escultura pensada de forma isolada das reverberaç̃os do espaço e da movimentação de quem a observa. Da mesma forma, apontou-se a "perda de substância" em relação à concepção original, feita junto com Serra, configurando um "fracasso artístico" 137, e a anulação do efeito de desorientação que supostamente deveria causar. Segundo essas críticas, boa parte desses problemas conceituais teria surgido ou sido agravada com o atendimento das solicitações feitas pelo Governo alemão e pela Embaixada Americana. Mas, ao analisar o modelo físico da primeira versão do projeto, noto que somente em um dos lados, o lado sudeste, as pedras se elevariam a uma altura suficiente para impedir um passeio livre do olhar, ou seja, somente a partir do lado sudeste não seria possivel olhar o Memorial como um todo. Esse dado coloca dúvidas com relação à responsabilidade das mudanças exigidas pelo governo na perda do dito espírito da "concepção original" (dúvida que talvez não seja tão presente com relação ao Centro de Informações).

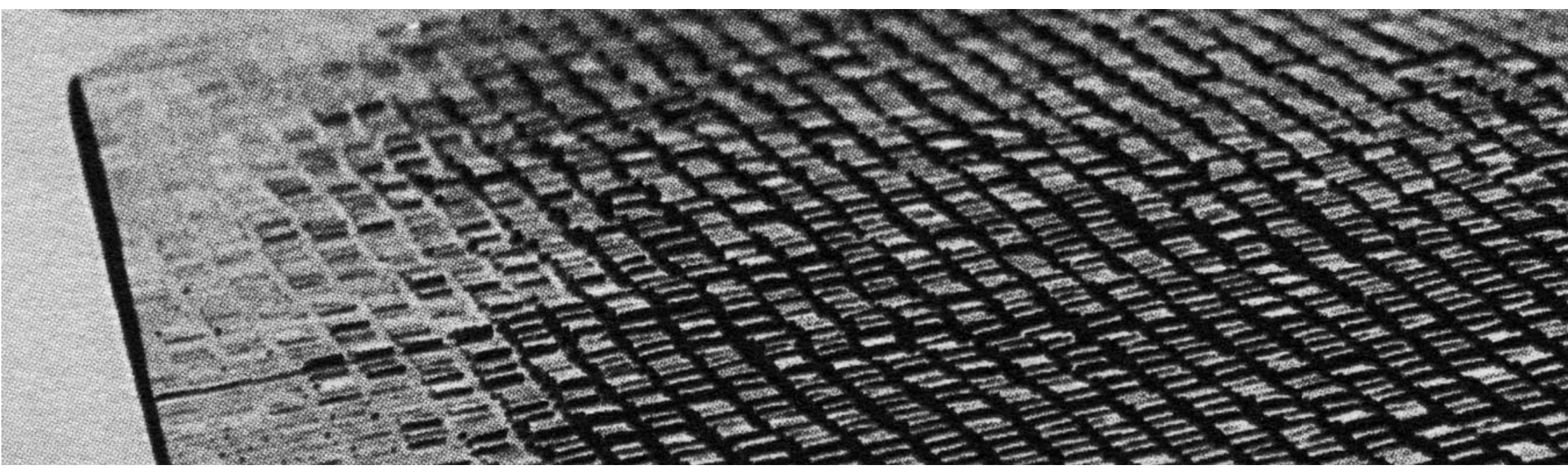

135. HEEMROD, Ute; SCHLUSCHE, Günter; SEFERENS, Horst. Der Denkmalstreit - das Denkmal? Die debatte
um das "Denkmal für die ermordeten Juden Europass: Eine Dokumentation. Berlin, Philo Verlag, 1999, p.200.

136. Segundo Richard Serra, em entrevista concedida a Peter Eisenman em 1983, foi Constantin Brancusi, no conjunto escultural de Targu Jiu, construído na década de 1930 na Romênia, quem marcou o rompimento com essa concepção na escultura. SERRA, Richard. "Interview with Peter Eisenman". 


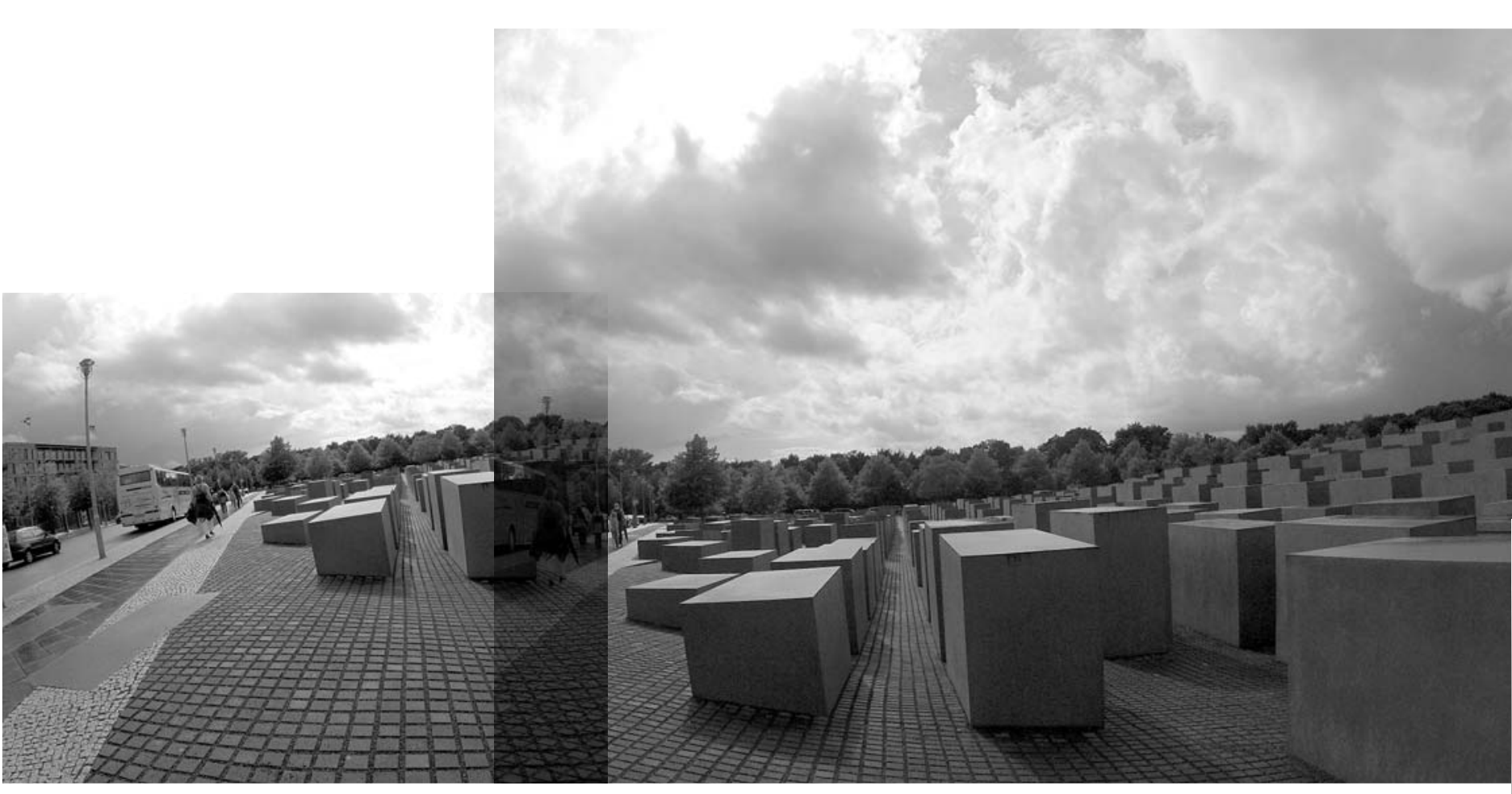

50.

De maneira suave, mas perceptível, o plano da calçada se converte em superfície curva, formando em alguns pontos um declive ao longo do qual as estelas parecem resistir à força da maré. Sentados sobre uma delas, e de costas para a rua, um casal observa as ondas petrificadas.

Com cautela, aquele gru-

po compacto que desceu

do ônibus, acompanha de perto um dos seus que

resolve se arriscar penetrando na descomunal massa cinzenta.

Um a um

e em fila indiana,

vão descendo pelo corredor estreito e

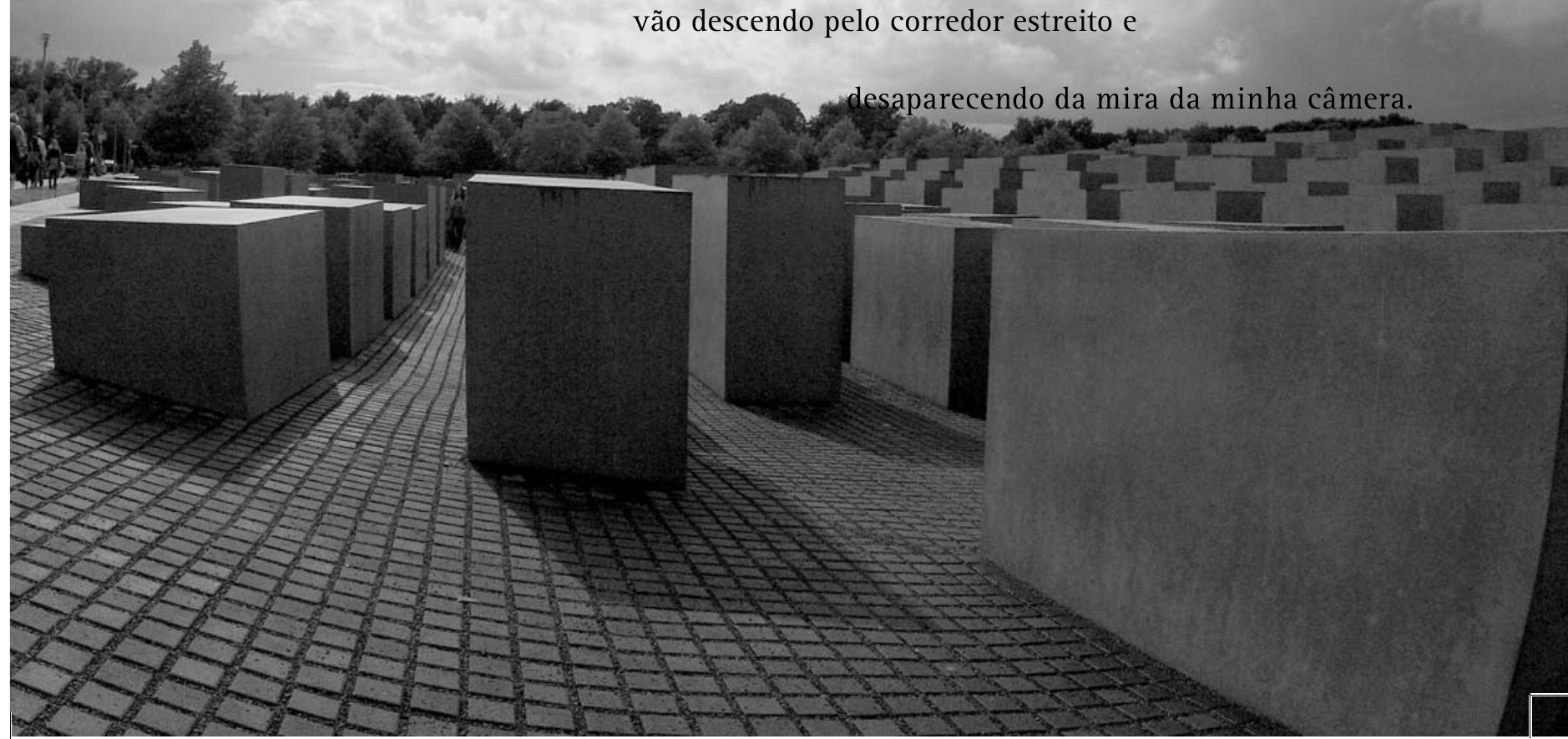


Até conseguir me aproximar daquele ponto e entrar pelo corredor onde se enfileiraram, já os perdi de vista. Resolvo então me desvencilhar da observação do grupo e partir para uma caminhada livre. Sigo em frente descendo a ladeira.

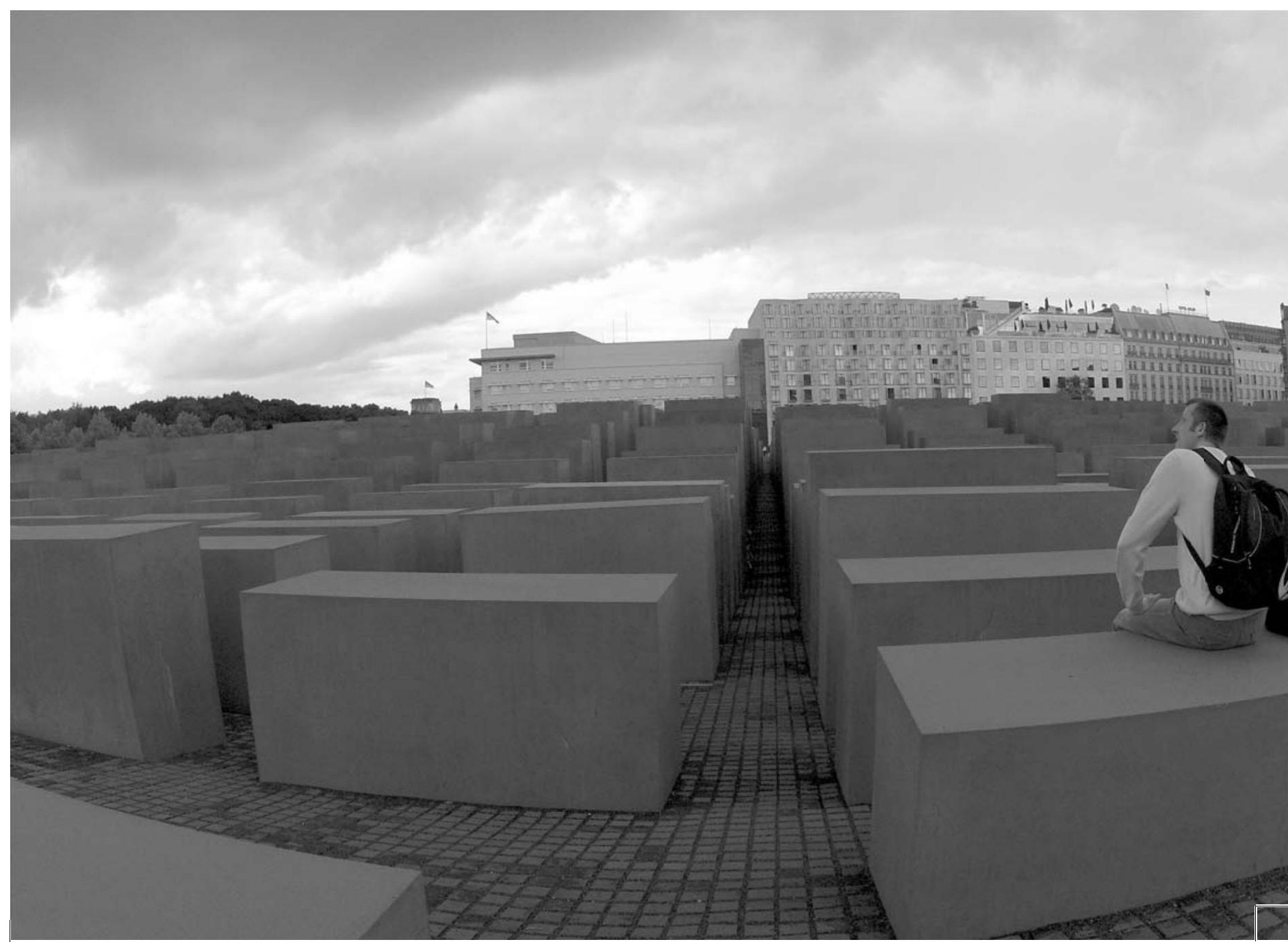


Lembro-me mais uma vez da primeira versão do projeto. Dessa margem pela qua estou entrando seria impossivel, segundo aquela conformação, não apenas ter a noção do conjunto - ou da obra como um objeto, diriam outros -, como também ver os topos das estelas, tocar com as mãos as afiadas arestas, reconhecer a sua aparênci

138. Aparência, pois as peças de concreto armado são, na verdade, ocas.

de volume maciço ${ }^{138}$, descobrir logo de cara, pela observação e sem precisar de deduzir a geometria da sua seção horizontal - que é recorrentemente associada à seção de um écorrentemente associada à seção de u túmulo -, ou ainda, ver a extrema variabilidade de alturas e inclinações que formam
as ondas do campo. Ao invés da imaginária superfície ondulada que produz um efeito de superficie ondulada que produz un efeito de movimento, eu veria la de fora, de maneira
bastante concreta, as grandes superfícies planas e verticais enfileiradas, uma mural ha permeável. Entrar na obra por aqui, seria como acessar um corredor através de uma porta, ou ainda, como penetrar na mata pelo espaço entre duas árvores.

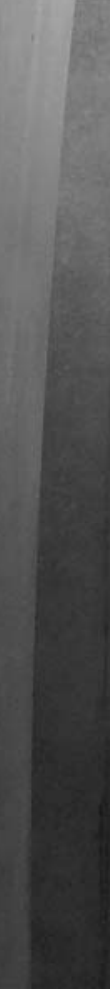

Da maneira como se construiu, entrar é como descer a praia até o mar: o primeiro anúncio de temperatura nos pés, a densidade e resistência da água nas canelas ntade do mergulho na altura da cintura, a visão de superfície na do peito e, por fim, já completamente submerso, o ensurdecimento e descoberta das reverberações subaquáticas.

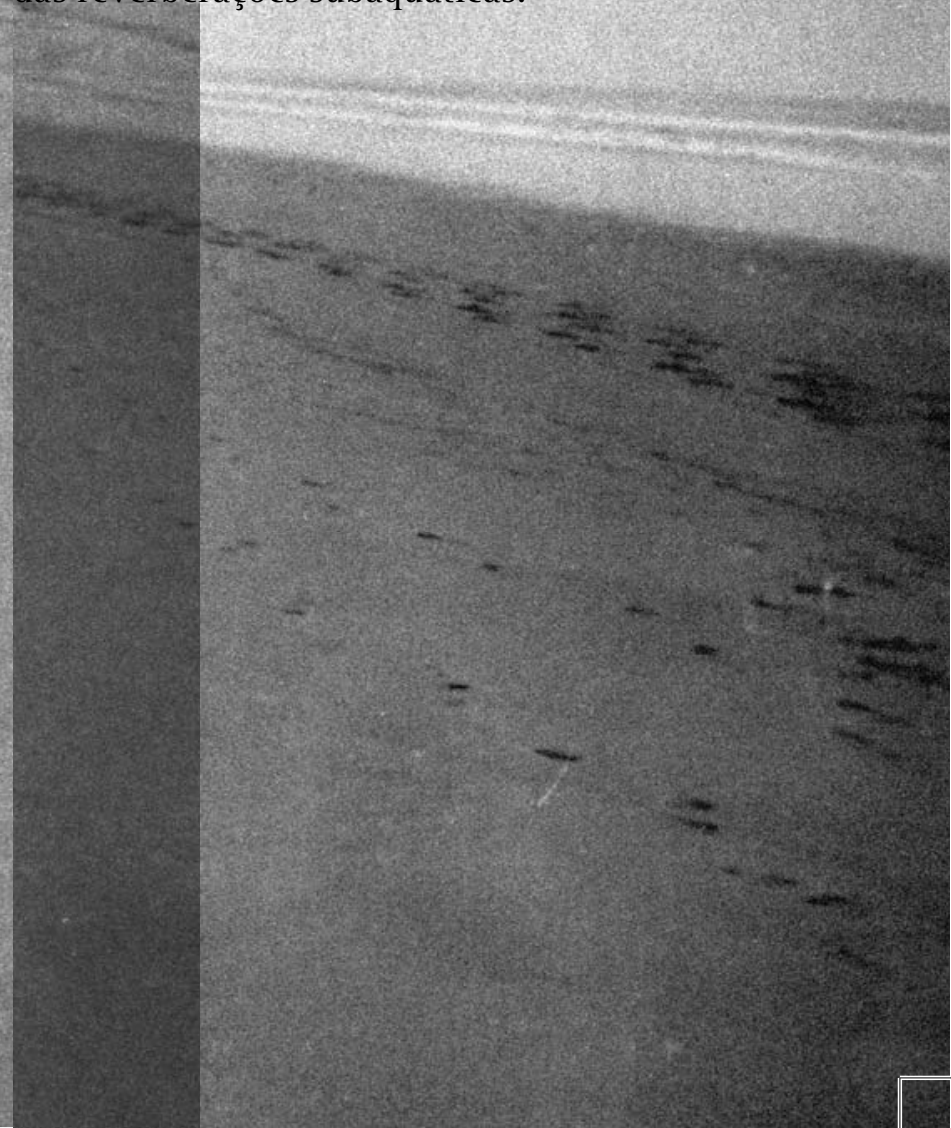


É curioso que um dos fatores responsáveis pela materialidade dos blocos do Memorial não tenha sido desejado por Eisenman ${ }^{145}$, mas imposto pelo governo alemão, ou seja, o tratamento anti-graffiti que acentua o brilho e a impermeabilidade dos blocos, e que dificulta a ação de pichadores, assim como daqueles que eram a maior preocupação das autoridades: os grupos neonazistas. A cobertura química teve que ser aceita pelo arquiteto, mas, no outono de 2003, o andamento da construção do Memorial esbarrou em grande polêmica ao redor dela. Tudo se deveu ao fato de que a substância usada no tratamento era produzida pela Degussa, uma grande indústria química alemã que durante o regime nazista produziu o Zyklon-B, pesticida usado nas câmaras de gás dos campos de extermínio. 0 produto que garantiria que as superfícies permanecessem imaculadas e livres de pichação, e que também foi responsável pelo realce da cor fria e do acabamento perfeito dos blocos, era fabricado por uma indústria que fez parte da máquina que reduziu seres humanos a montes de cinzas ${ }^{146}$.
0 fato, inicialmente terrivel, gerou uma reflexão a respeito da maneira como a Alemanha lidava com seu passado e com a sua responsabilidade pelo Holocausto. 0 argumento central que levou à decisão de prosseguir com a obra e com o produto da Degussa baseava-se na impossibilidade de se construir na Alemanha de maneira absolutamente dissociada de qualquer indivíduo ou empresa que não tivesse participado ou sido conivente com o Holocausto. Muitas das atuais gigantes da indústria alemã não apenas apoiaram o nazismo, como também utilizaram o trabalho forçado de prisioneiros judeus, possuindo em alguns casos, sedes estrategicamente instaladas próximas aos campos de concentração.

145. EISENMAN, Peter; SPIEGEL. "How Long Does One Feel Guilty??". Disponivel em: <www.spiegel. delinternational/spiegel-interview-with-holocaust-monument-architect-peter-eisenman-how-long-

146. A analogia com a cor dos monólitos, embora pouco fértil, não pôde ser evitada.

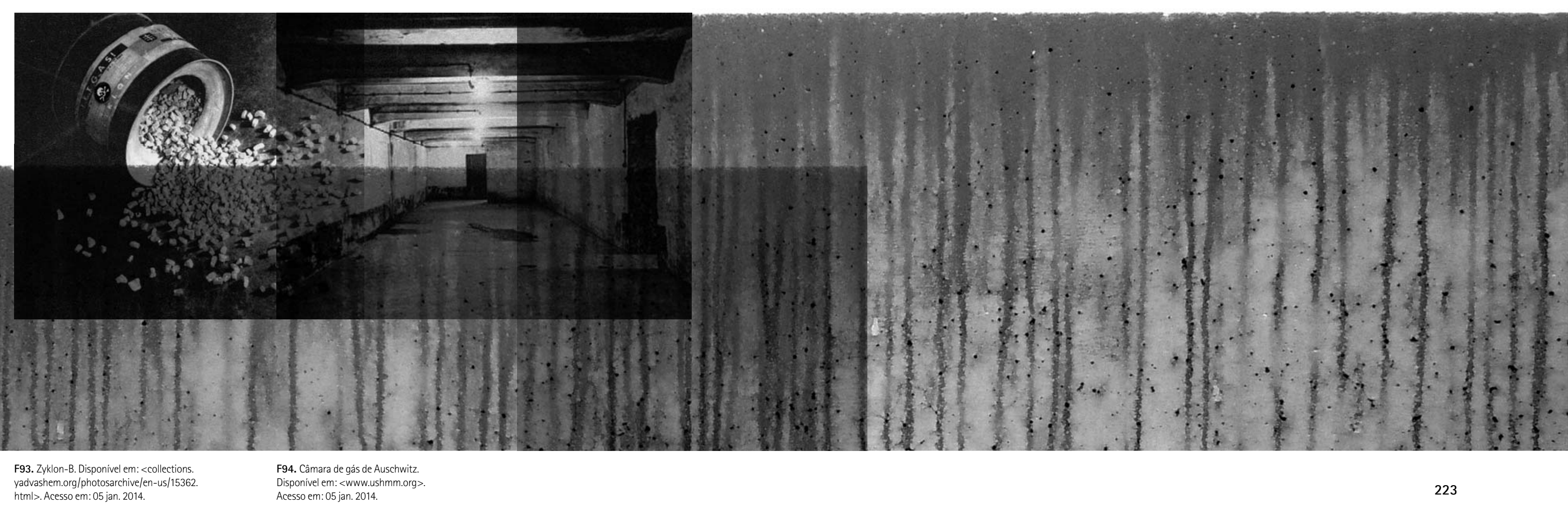




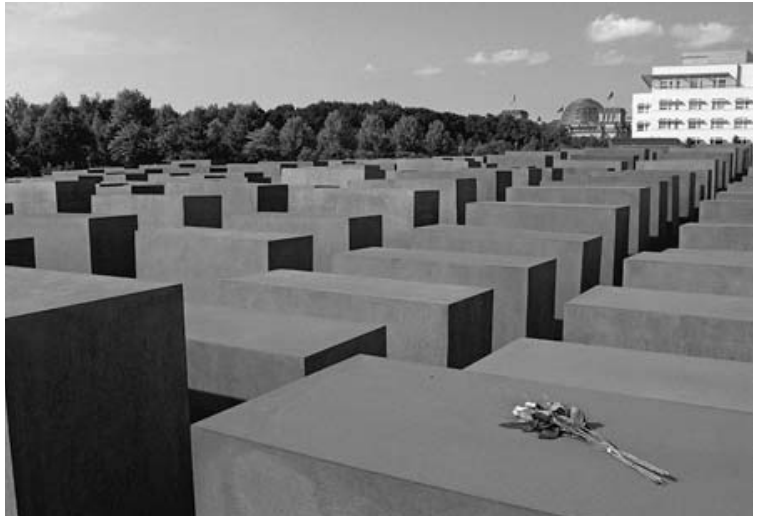

55.

Sobre a superfície do topo de um dos blocos estão depositadas três pequenas pedras. Alguém as colocou aí, lembrando-se do antigo ritual judeu que marca a visita aos parentes mortos. 0 bloco de concreto se converteu em túmulo e o Memorial em cemitério. Estamos em Berlim,

a capital da Alemanha, e o Memorial se trans-

formou em um grande campo de pedras depositadas sobre o seu solo para lembrar de seis milhões de pessoas mortas.

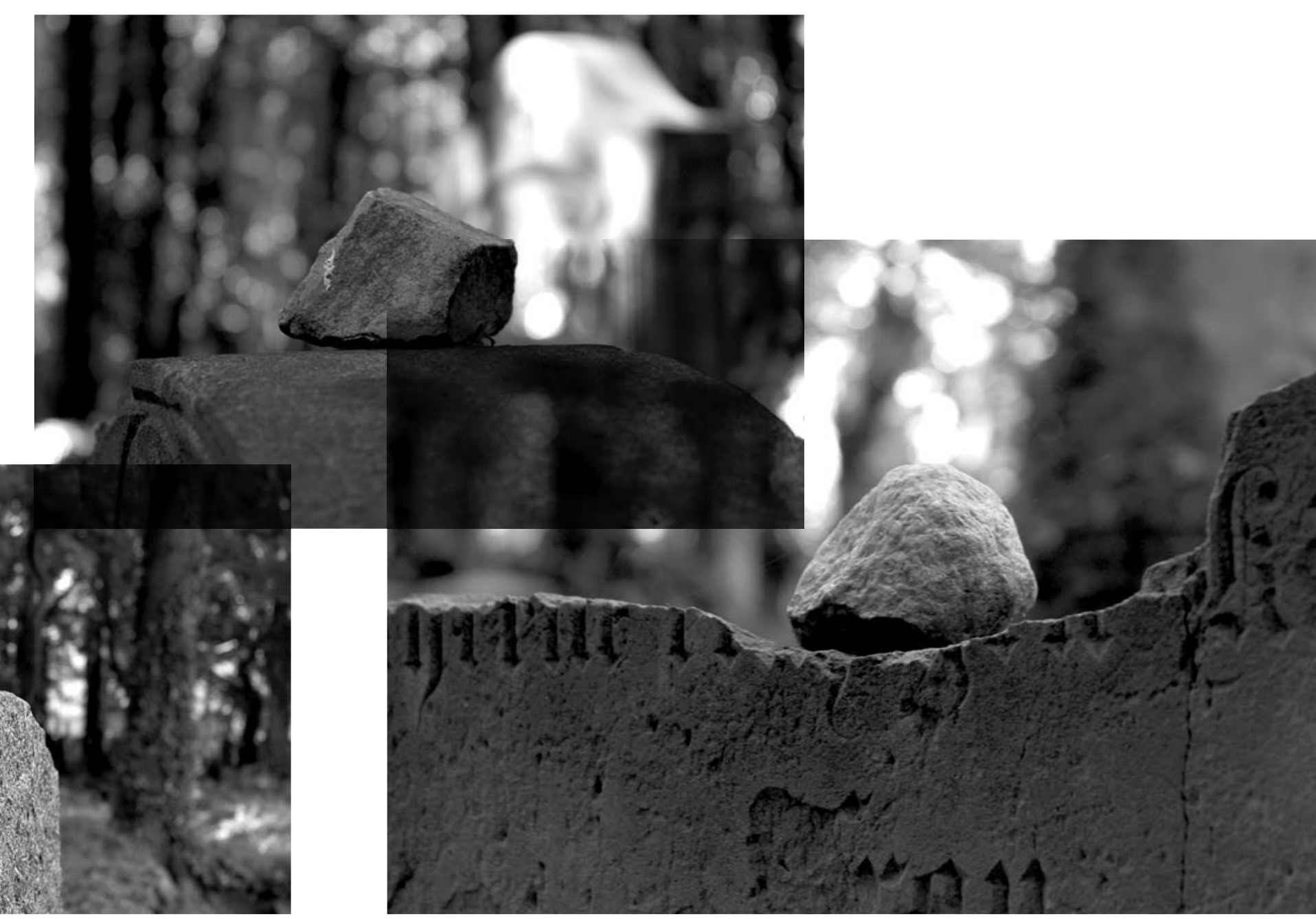

F96. STIFTUNG DENKMAL FÜR DIE S. STIFTUNG DENKMAL EÜR DIE
ERMORDETEN JUDEN EUROPAS. Materials on the Memorial to the 


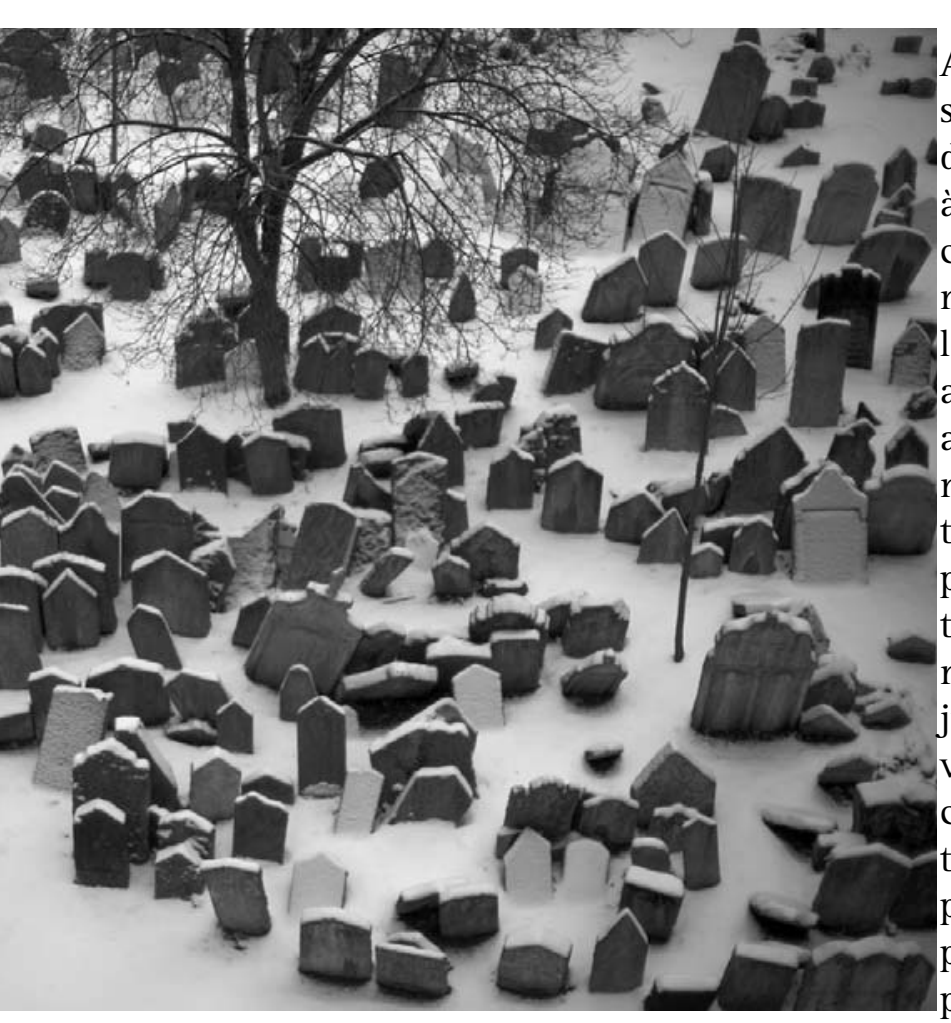

força de lei que uma simples as ociação pode ganhar no processo interpretação da obra, somada a ideia de representação entendid como figuração, parece ter sido o motivo de algumas confusões de eitura e - em parte, talvez devido como muitas vezes esse tipo de artifício é visto com maus olhos o meio arquitetônico - de quesionamentos ou reprovações por parte da crítica. A associação com túmulos e cemitérios - especialmente com um antigo cemitério udeu em Praga, evocado em diversos textos - recaiu sobre a obra om tal força, que acabou por se ornar uma espécie de explicação ara a configuração do conjunto para a volumetria do seu elemento rimário, o monólito de concreto.

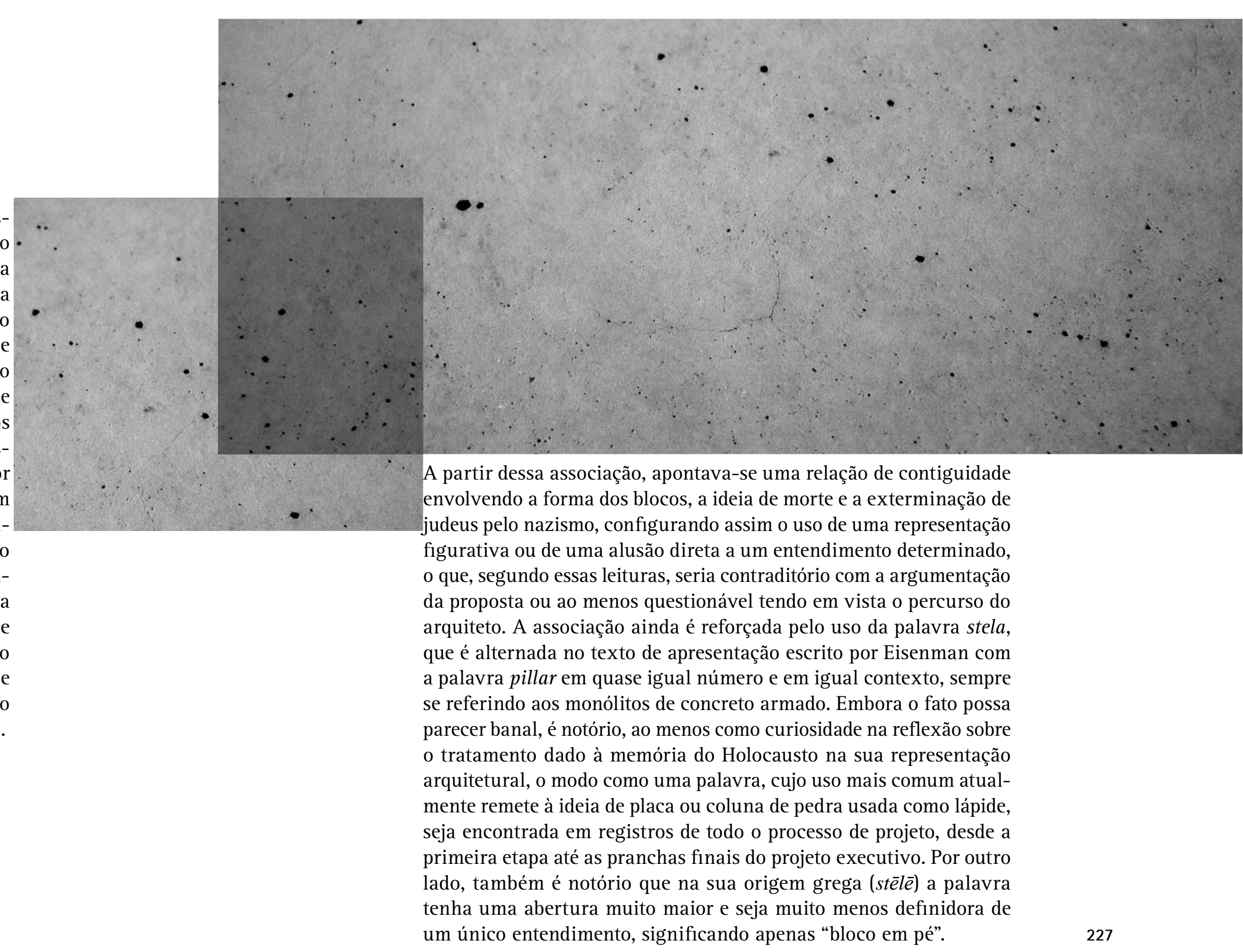

227 


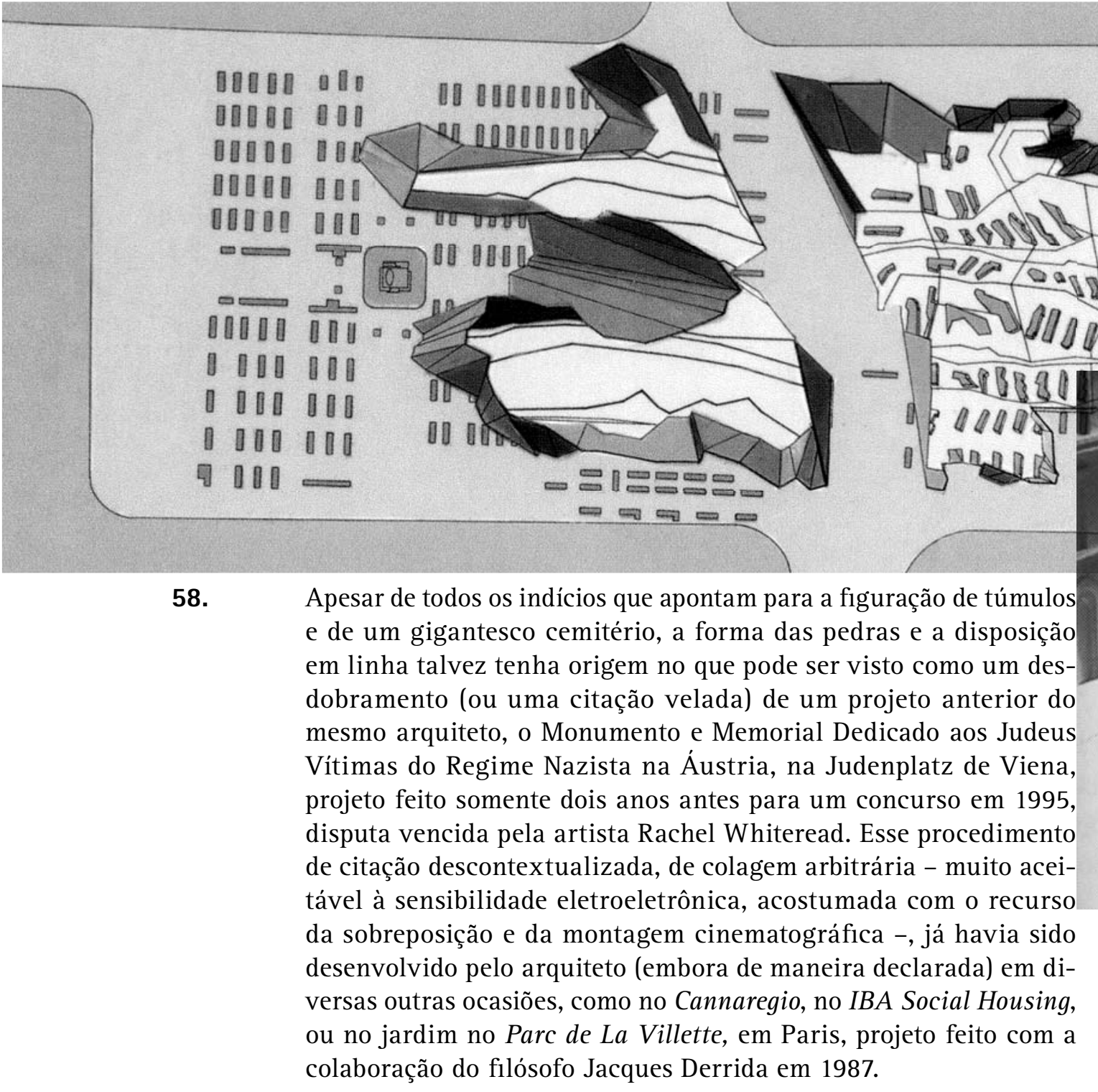
colaboração do filósofo Jacques Derrida em 1987.

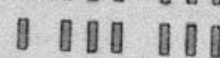

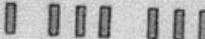

1000 010

पी०

Apesar de todos os indícios que apontam para a figuração de túmulos e de um gigantesco cemitério, a forma das pedras e a disposição (ou uma (los Vítimas do Regime Nazista na Austria, na Judenplatz de Viena, projeto feito somente dois anos antes para um concurso em 1995, tencida pela artista Rachel Whiteread. Esse procedimento da sobreposição e da montagem cinematoóráfica -, já havia sido desenvolvido pelo arquiteto (embora de maneira declarada) em di-
No projeto de Viena, Eisenman efetuou a sobreposição de diversos mapas e o cruzamento de camadas e niveis determinando a configuração espacial da praça. Na primeira camada usou dois mapas de guetos judaicos em Viena, um destruído em 1421 e o outro em 1678 escalados de forma a ajustar-se à dimensão da área. Na segunda, o mapa da Áustria e da Alemanha, indicando a anexação em 1938. E finalmente, a terceira, com a representação bidimensional da planta do complexo de Auschwitz, com seus enormes galpões retangulares organizados em uma típica instalação militar.

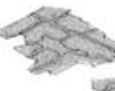

5182

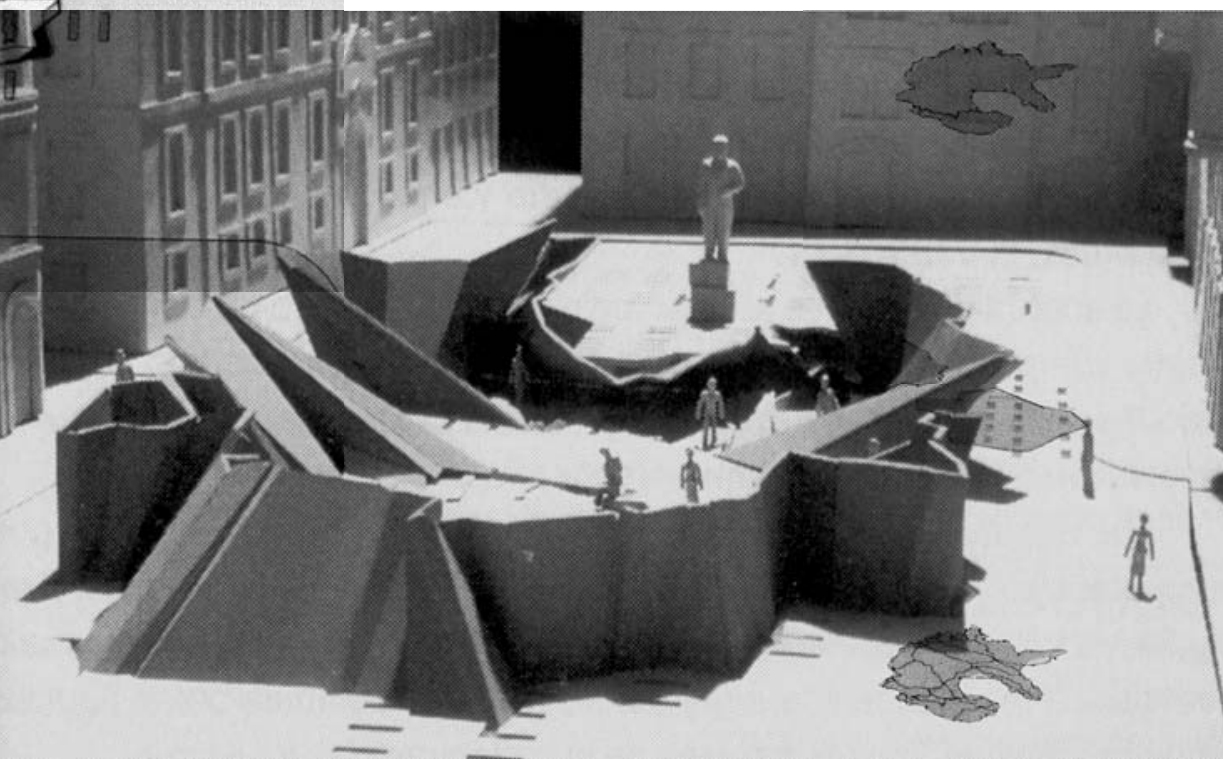

-
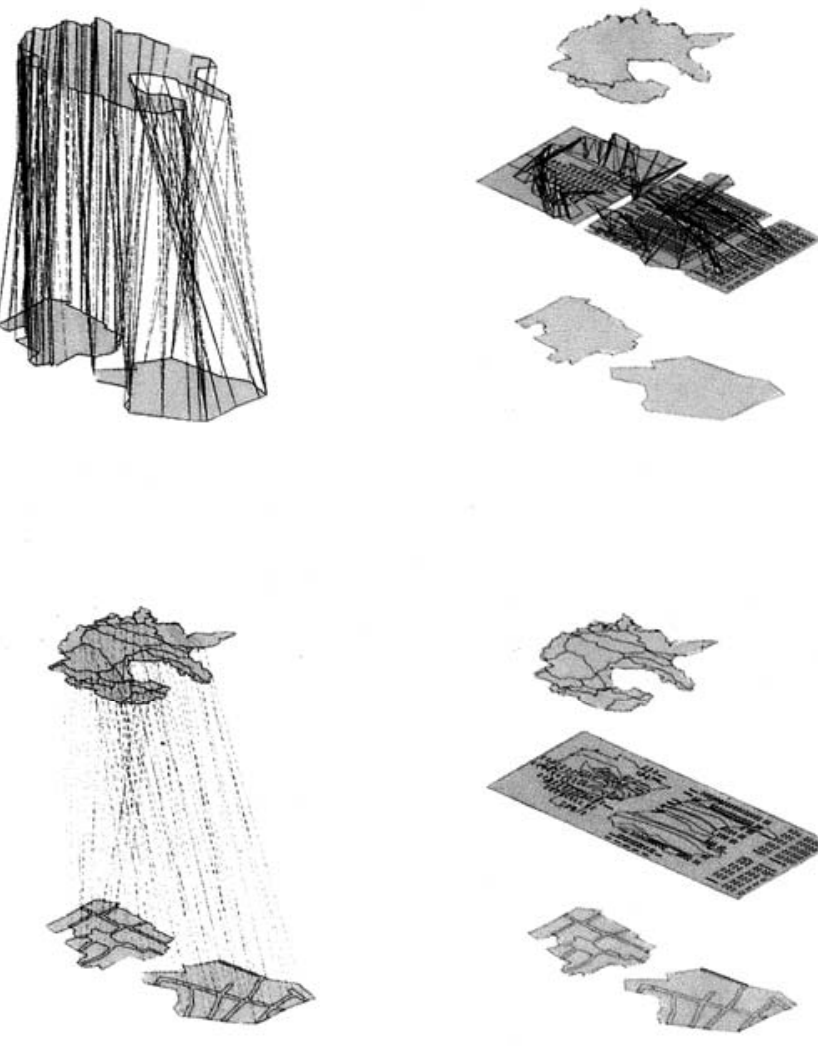

F104. Diagramas,
EISENMAN, Peter EISENMAN, Peter
Diagram Diaries Diagram Diaries
London, Thames 8
Hedson, 1999.9 
É curioso que da associação com túmulos e cemitérios e daquilo que talvez seja a origem da forma dos blocos e do conjunto, ou seja, a planta do campo de extermínio de Auschwitz, reste como elemento em comum somente a similaridade visual e a ideia de morte. Isso se torna fato de grande importância, pois pode indicar, senão um considerável domínio no que diz respeito à consciência do suporte de representação e da comunicação na arquitetura, uma feliz coincidência de elementos formando algo um pouco mais próximo da desejada complexidade na representação da memória do Holocausto.

Ao mesmo tempo, a associação com o cemitério judeu de Praga, cuja origem na cronologia dos textos críticos ainda não pude identificar, é, a meu ver, relevante apenas no que se refere à inclinação das pedras. Excluindo-se o fato de ser reservado somente aos judeus, não sobram muitos elementos de conexão com a configuração formal e conceitual do Memorial dos Judeus Assassinados da Europa Poderíamos evocar a lembrança do cemitério da qual falei a pouco, mas mesmo isso seria uma ligação frágil se considerarmos a existência, não muito longe daqui, de outros tantos cemitérios judeus tão antigos quanto o de Praga e até mais significativos do que ele, tanto com relação à similaridade - pela organização dos túmulos e pela forma das lápides - quanto pelo significado sentimental e histórico para os judeus, se lembrarmos do cemitério demolido durante o nazismo na Grosse Hamburger Strasse.

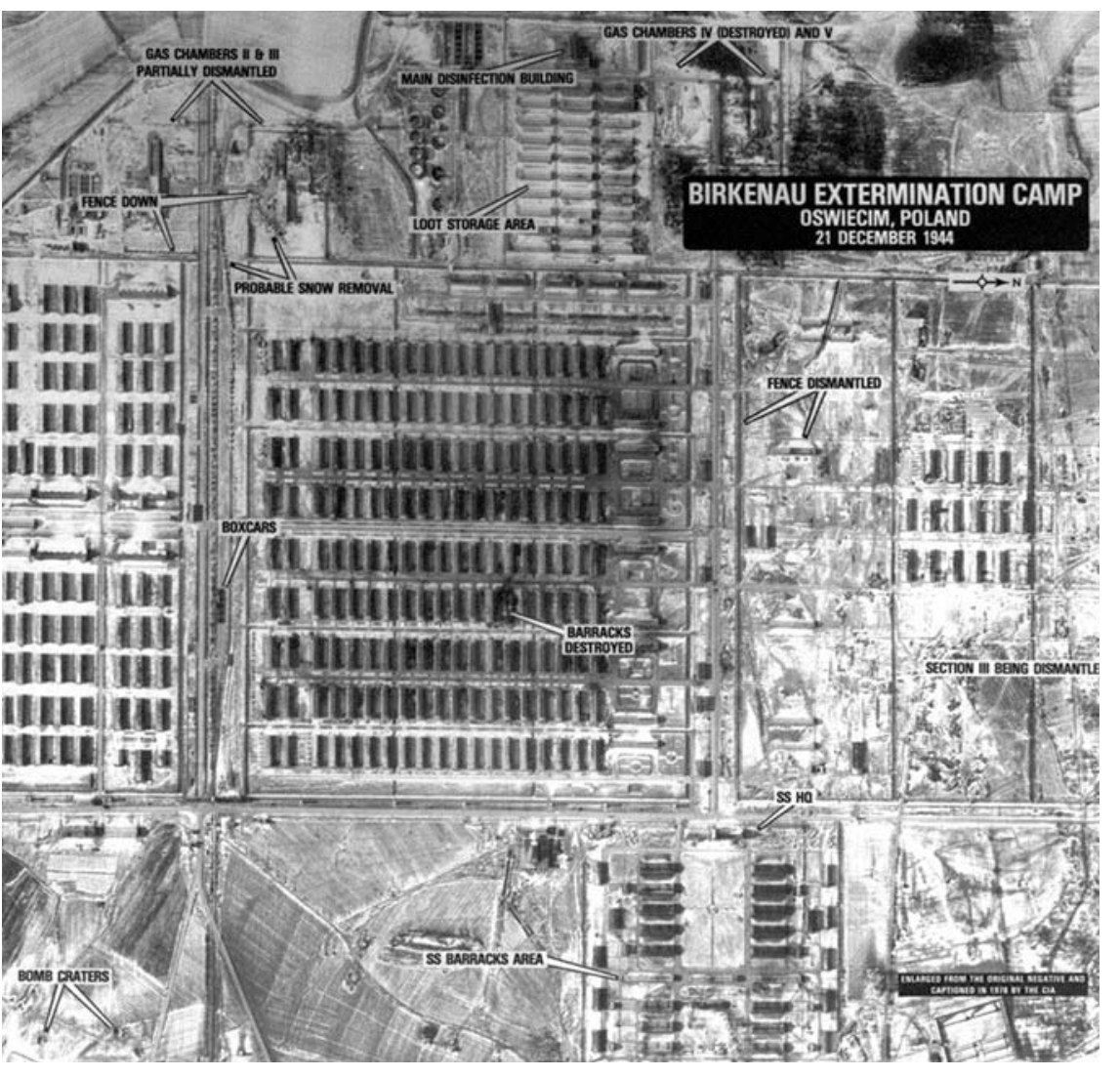

232

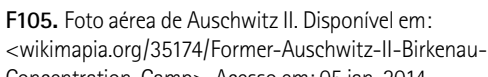

$<$ <wikimapia.org//31744/Former-Auschwitz-II-Birker
Concentration-Camp>. Acesso em: 05 jan. 2014.

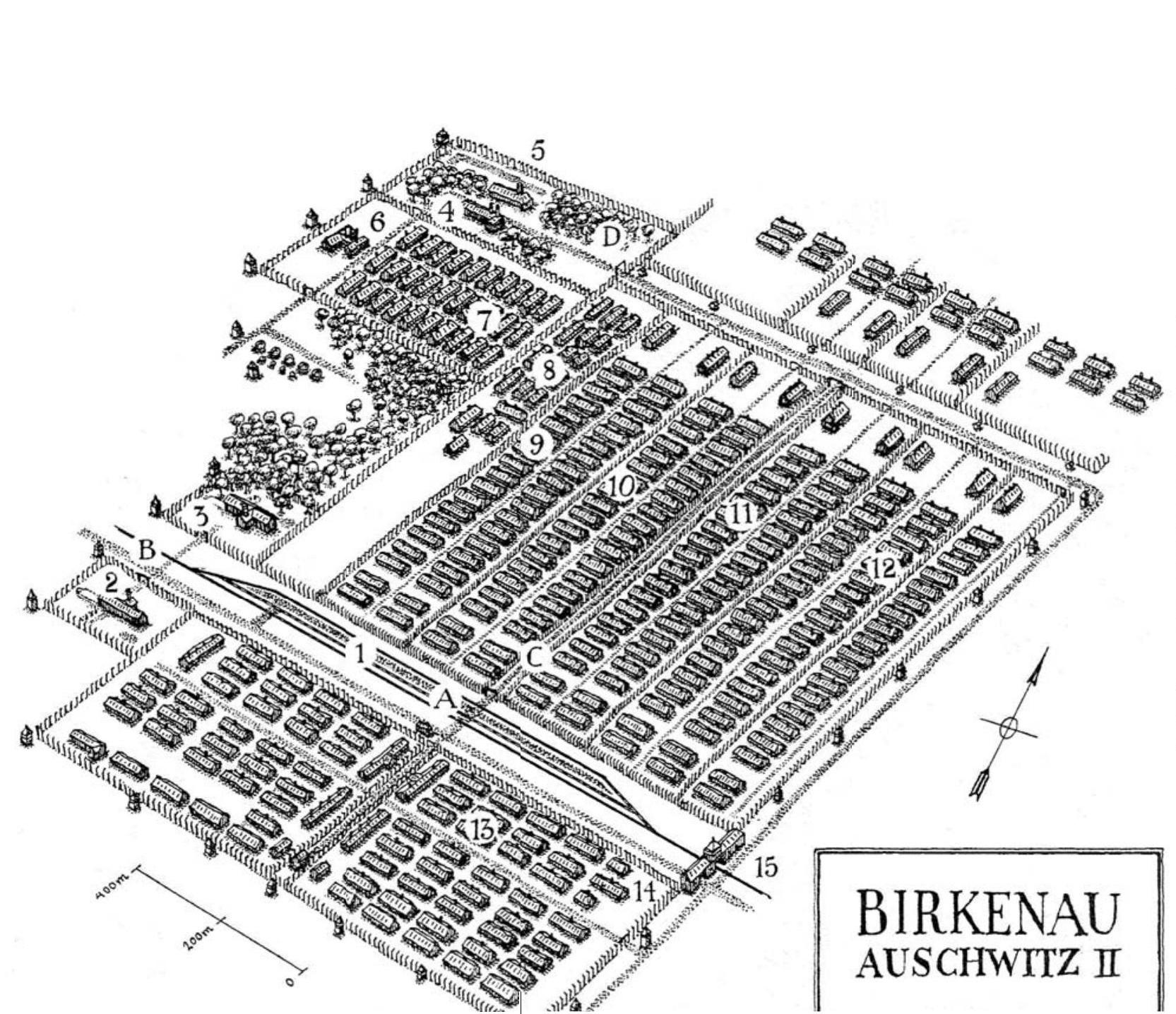

AUSCHWITZ II
F106. Perspectiva de Auschwitz II. Disponivel em:
<codoh.com/library/document/2837>. Acesso em 05 jan. 2014 .

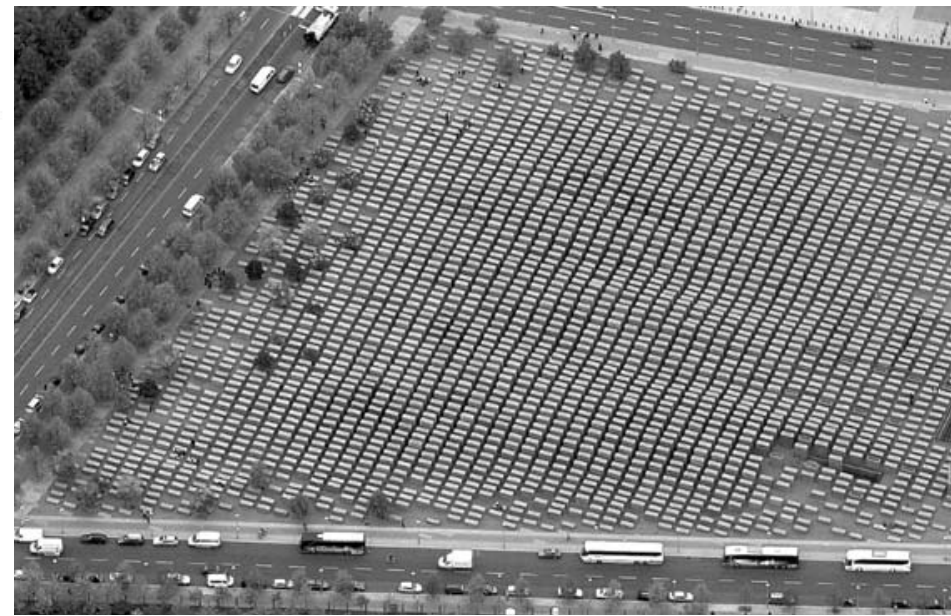


0 vazio que se anunciou tão fortemente assim que eu me aproximei dessa quadra do Memorial é o que permite a ideia de margem, tanto da cidade como da obra, e que, junto com a curvatura que o plano do chão desenha a partir do limite da calçada e dos ladrilhos pretos, a ideia do mergulho. A visão, que a pouco havia ganhado a possibilidade de flutuar livremente pelo espaço, é novamente, à medida que eu avanço pela ladeira, obrigada acompanhar o alinhamento dos blocos, a seguir a perspectiva dos corredores, assim como antes acompanhava as fachadas dos edifícios e, com esse confinamento, era fatalmente conduzida para frente: 0 ponto de destino. A forma da rua possui uma íntima ligação com o principal significado a ela atribuído, ou seja, o uso efetivo como ligação entre lugares e entre pessoas: um bairro a outro, o trabalho à casa, etc. A similaridade entre a rua da cidade e a rua do Memorial - similaridade que se dá não apenas em termos visuais, mas, sobretudo, pela maneira como me desloco no espaço - restabelece uma relacão (e não uma forma específica) interrompida pelo vazio da quadra. Mas aqui não há casas, não há pessoas a quem visitar, não há pontos a serem ligados nesse mar de elementos indistinguiveis, de corredores estreitos inumeráveis. Não há sequer, a princípio, razão ou sentido no deslocamento que não o próprio deslocamento. A forma da rua aqui está desprovid da função que possui na cidade e de todos os sentidos ela associados, as particularidades de cada casa, de cada esquina, das identidades de seus moradores, as memórias ndividuais e coletivas, está reduzida a uma relação espacial na qual a pequena largura do corredor me obriga a olha para frente, a seguir andando por ele sem que eu tenha un motivo específico para isso, a cruzar incontáveis travessas sem a esperança de alcançar a visão de algo novo.

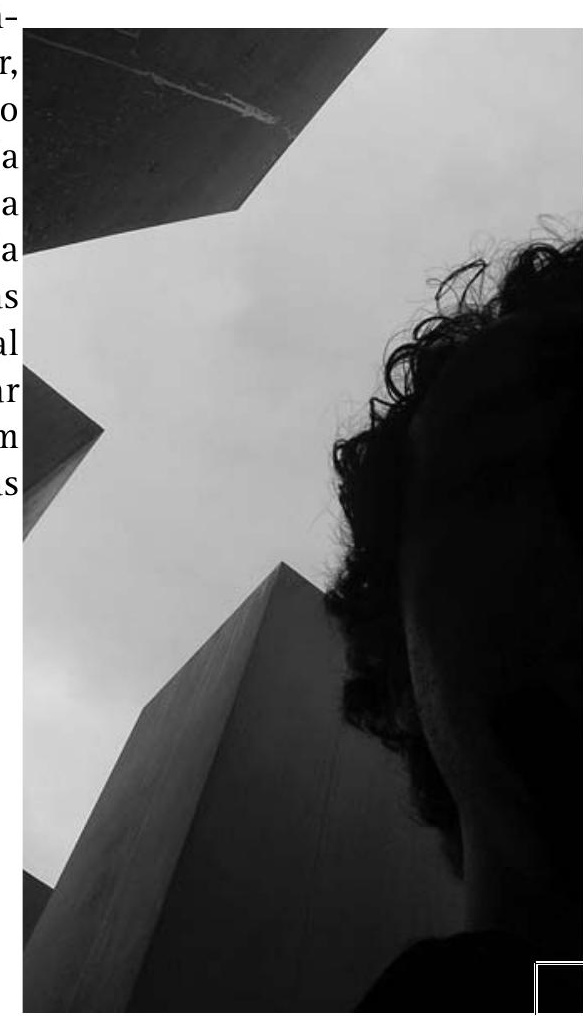


corredor tanto quanto o volume dos

monólitos - noventa e cinco

metros de largura em ambos - e no

sentido transverso, o Leste-Oeste, a

relação cheio-vazio muda para uma

proporção de dois e meio para um,

uma grande diferença de permeabi-

lidade. Em todas as ruas intercalam-

se faixas verticais em infınidades de

tons de cinza escuro que, com a re-

petição ao longo de toda a extensão,

criam um forte efeito de perspectiva.

No ponto de fuga, a visão de uma

pequeníssima parcela da rua.
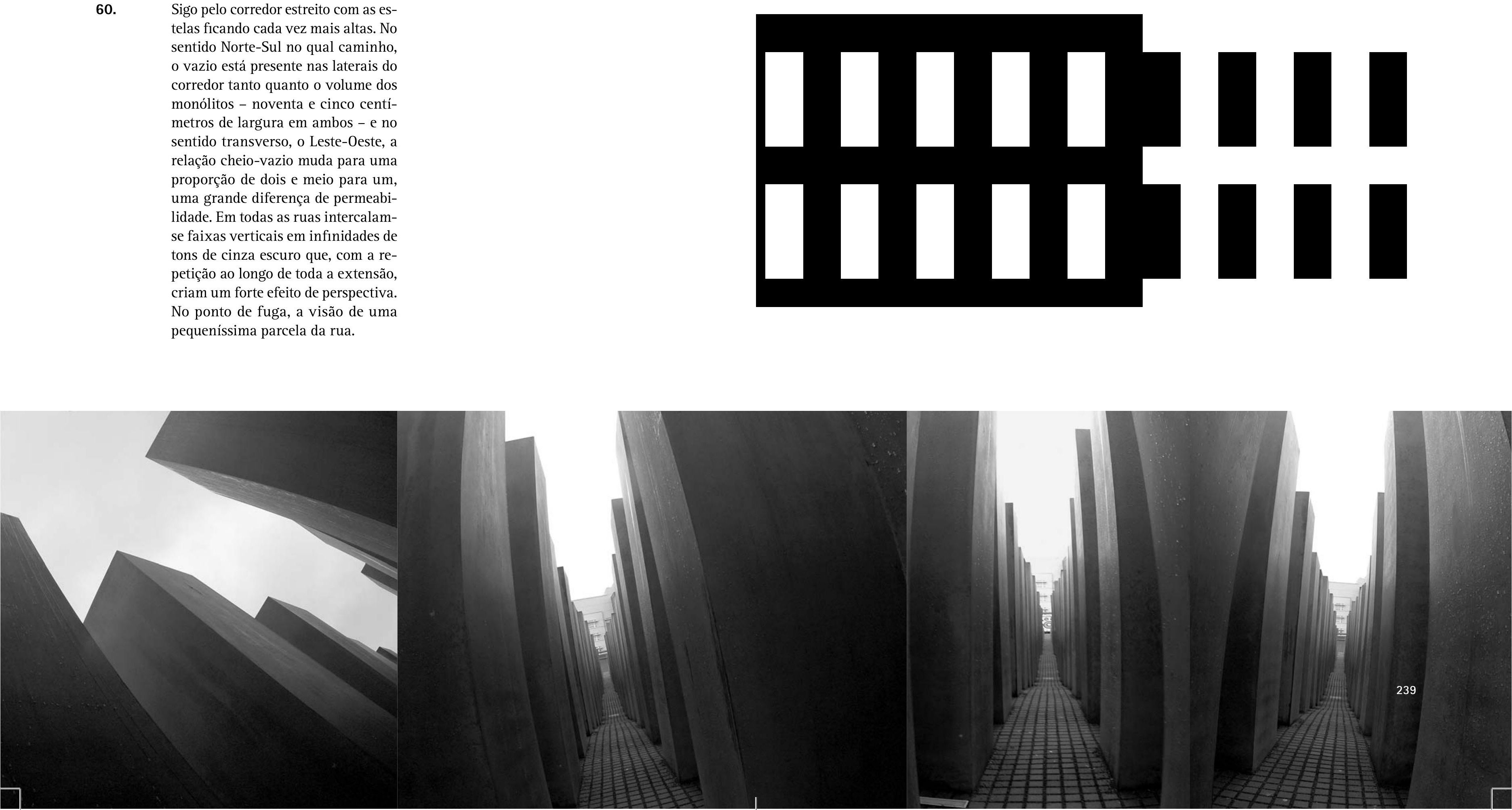
0 céu aqui dentro ganha forma, dimensão, ângulos e arestas. Se nas margens da obra ele dominava a paisagem, aqui é restrito ao enquadramento dos corredores, ao espaço entre os pilares. A luz difusa desse dia meio encoberto, que não deixa chegar aqui em baixo nenhum raio de luz direta, e a cor escura que ocupa todas as superfícies, tanto das paredes, como do piso, gera um achatamento de tons em um contraste que explode as fotografias automáticas dessa câmera: o branco das nuvens contra o preto das estelas. Essa visão contrastada reforça em mim a noção de que caminho no espaço negativo das estelas, naquele que sobrou entre as fileiras. Se de fora, na margem, temos a impactante visão de uma gigantesca massa cinza cuja unidade é reforçada pela possibilidade de vê-la por inteiro e pela fácil analogia com o mar, com algo que, pela sua natureza fluída, se molda ao terreno ocupando todos os espaços disponíveis, no mergulho penetramos por entre as pedras, descobrindo que aquele corpo é extremamente poroso, atravessado por uma infinidade de ruas que permitem a caminhada em qualquer direção. Apesar do peso das grandes pedras de concreto que se impõe ao olhar não somente pela sua materialidade, sua cor e aparência sólida, mas também pela altura que em alguns pontos chega a quase cinco metros, recortando o céu em estreitas faixas cruzadas, impedindo a visão da cidade e a chegada de seus sons, o Memorial se faz mais de vazios do que cheios. Na verdade, e contrariando a minha percepcão, o volume da de monólitos. É só aqui dentro, depois de mergulhar, de começar a andar sem rumo pelos corredores e me assombrar com essa arquitetura improvável, que me deparo com essa revelação e entendo que esse espaço não se faz apenas daquilo que é construído, mas, sobretudo, pelo vazio, pela entrelinha dessa escritura de concreto, pela possibilidade de andar no meio dos blocos, o branco do céu recortado, os raios de sol desenhando formas geométricas nas pedras e no chão, o ensurdecimento do som da cidade e o isolamento das vozes daqueles que nele se perdem. 
Se na margem o que faz a obra é a visão do monumento, no mergulho é o vazio. Mas não exatamente como nos trabalhos de Rachel Whiteread, onde a artista revela a forma do vazio com uma construção negativa e nos oferta a possibilidade de atravessar com nossos corpos e olhares o espaço antes ocupado pelas paredes de uma casa ou uma estante de livros. As obras de Whiteread tentam transformar as coisas conhecidas e cristalizadas pelo hábito revelando o vazio, a parcela não visível. Aqui no Memorial ocorre algo um pouco distinto. Poderíamos imaginar que, como nas obras da artista, revela-se de maneira invertida o espaço vazio de um conjunto de covas escavadas em um pequeno monte. Essa associação, embora possivel de ser feita, parece demasiadamente dependente de uma associação anterior, ou seja, a identificação da geometria do bloco com um túmulo. Mas aqui, pela maneira como são configurados os corredores e pela elevação do conjunto em relação ao nível da calçada, impedindo uma visão aérea, não apenas o reconhecimento de um bloco isoladamente é dificultado, pois a ele se sobrepõem tantos outros, como também não podemos ver do vazio nada mais do que dois estreitos corredores de cada vez, um no sentido Norte-Sul e outro no sentido Leste-Oeste. 
Pedaços de gente nas minhas fotografias: uma perna dobrando, metade de uma cabeça, um olhar de canto, uma mão, costas, mochila, a ponta de um guarda-chuva. 0 movimento das pessoas é escorregadio para essa precária câmera de disparos automáticos. Fico aqui parado torcendo para que, quando puder avaliar o material desse ensaio fotográfico às cegas, consiga ter flagrado alguém por inteiro. Depois de ver e fotografar da margem um visitante desaparecendo no mergulho, vejo-o rapidamente cruzando o corredor ao lado. Tento encontrá-lo para que seja novamente capturado pela lente. Nada feito. Desapareceu mais uma vez entre os blocos.

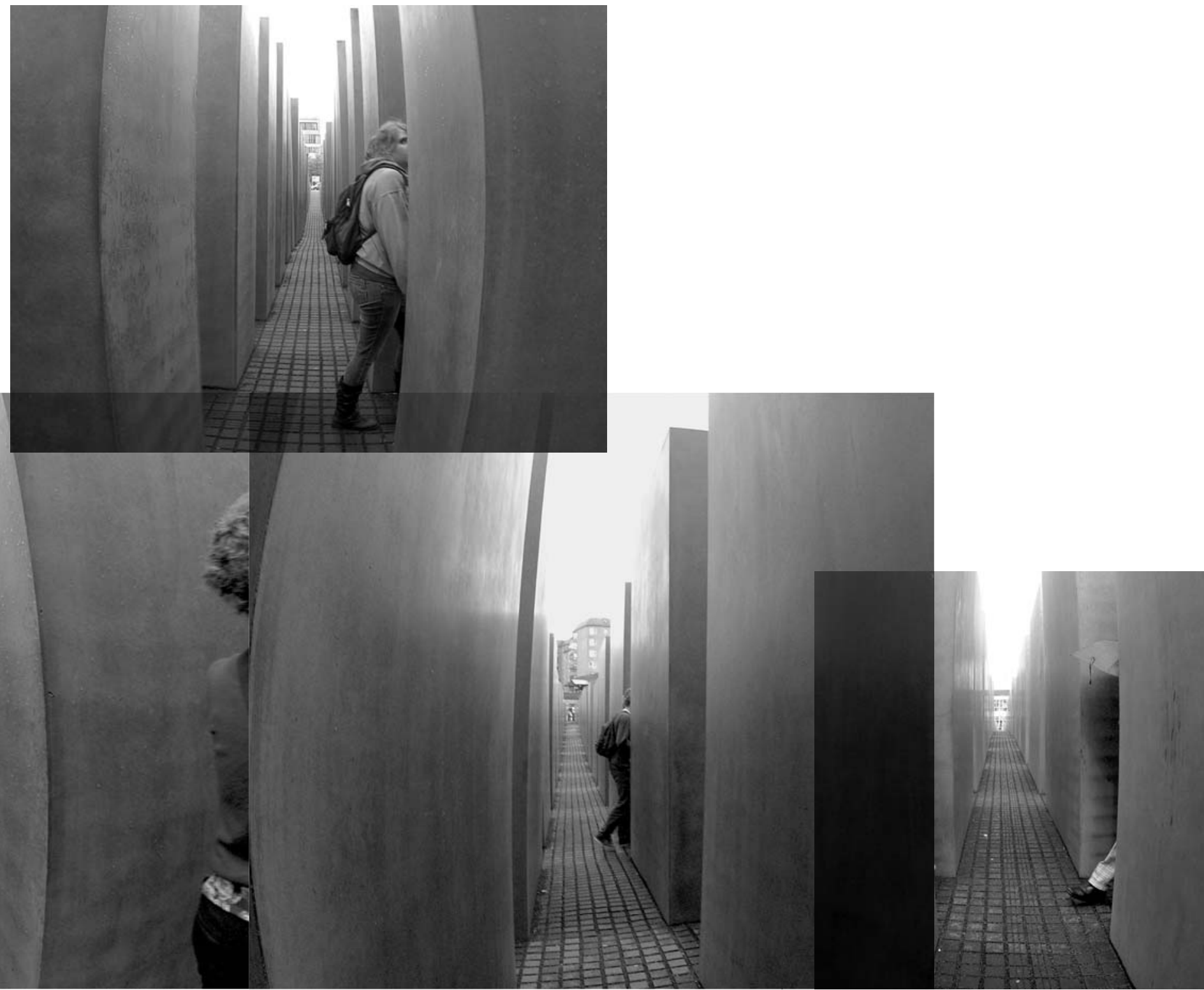


Uma coisa curiosa ocorre nesses corredores: a cada transversal que cruzo, é quase impossível resistir ao impulso de olhar para pelo menos um dos dois lados, como quem atravessa uma rua com o cuidado de não ser atropelado. Com a repetição desses corredores a cada duas passadas, andar em linha reta vira uma tarefa às vezes cansativa. Mesmo sabendo o que posso esperar encontrar em cada um dos corredores - depois de cruzar alguns deles e avistar a repetição da paisagem -, busco uma surpresa, uma peça diferente, uma clareira, uma pessoa. A procura de uma novidade, dobro mais uma esquina.

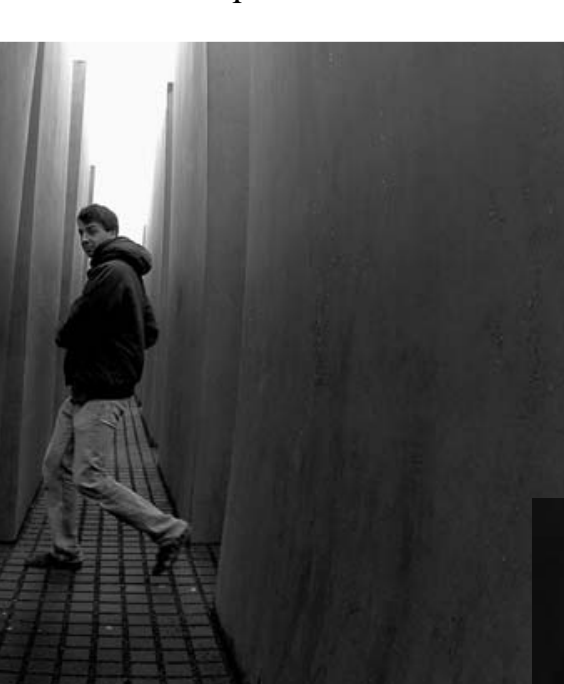

Vejo ali no fundo do corredor: as rvores do Tiergarten, um poste, um carro que passou. Vejo, mas não escuto. Escuto apenas um som abafado, um ruído grave que poderia vir de qualquer lugar. Junto com o recorte microscópico da rua e o canto dos pássaros, é o que restou da cidade. De maneira muito nítida, a reverberação da minha voz, o tecido de nylon da minha mochila e o atrito da sola do meu sapato com as pedrinha pretas que preenchem o espaço ntre os ladrilhos quadrados. Sem poder detectar ao certo a origem, uma constelação de vozes, risos, passos apressados e gritos de susto que se misturam uns aos outros: escuto, mas não vejo. A dureza e polidez das paredes escuras dos corredores faz chegar até aqui o som de uma pessoa que não esteja muito longe de mim, mas não a sua luz. Percebo que, quanto mais nítido distinguivel o som, maior e proximidade da fonte e, com ssa espécie de radar de morcego, consigo adivinhar a trajetória de lguém que se aproxima.

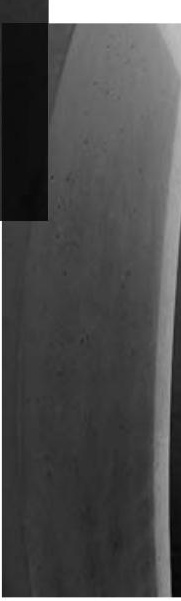

De um corredor derivam muitos outros. Esse, por sua vez, a derivação de um anterior que derivou daquele pelo qual entrei. Dentro das possíveis combinacões, a genealogia do meu percurso provavelmente não será mais repetida.

66.

A regularidade com que tudo se repete - as estelas, os corredores, os ladrilhos quadrados do chão - e o rigoroso alinhamento e modulação de todos os elementos faz saltar à vista a sinuosidade do chão: repleto de ondas pequenas no sentido Norte-Sul e com uma grande e suave concavidade no sentido Leste-Oeste.
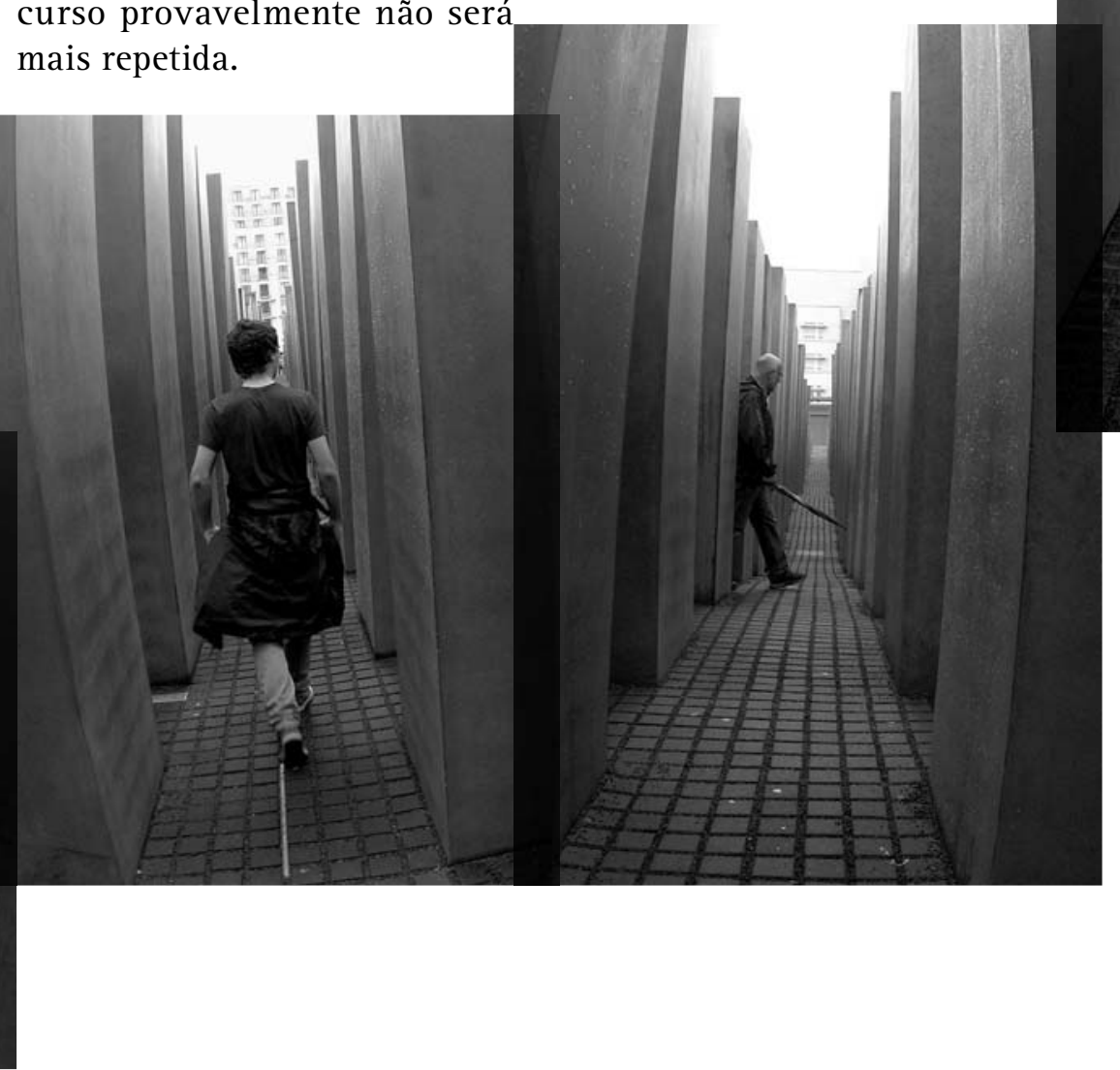
A associação com o sentido ${ }^{147}$ e com a figura ${ }^{148}$ do labirinto, vinda talvez de uma rápida citação no texto de apresentação ${ }^{149} \mathrm{e}$ do efeito de desorientação atribuído a alguns projetos do arquiteto, não parece resistir além do momento em que vejo a obra das bordas. Assim pedras e a finitude de todas as ruas no limite da calçada, percebo que o espaço interno do Memorial passa muito longe da ideia de labirinto. Não li e nem ouvi de Peter Eisenman muitas declarações que apoiam a ideia que eu havia lido em uma série de textos críticos e que eu acabei trazendo na minha bagagem, a de que o campo de

estelas buscava provocar uma desorientação semelhante à do labirinto. Na verdade, só encontrei uma, dita de maneira um pouco mais direta, na qual o arquiteto teria conversado com sobreviventes de Auschwitz que relataram um "sentimento de desorientação e perda”, motivando, segundo o autor do artigo $0^{150}$, a criação de um sentimento análogo. Não pude verificar, pela ausência de referências, a veracidade das declarações citadas no artigo, mas, de fato, isso pouco importa após eu experimentar o espaço. Por mais que eu tente me perder, virando bruscamente repetidas vezes a cada corredor que encontre - experimento que talvez eu tenha feito para tentar comprovar aquela ideia -, bastam frações de segundo para que eu reconheça a silhueta da cidade despontando em cada um dos quatro finais de corredor que consigo enxergar. A navegação aqui é garantida pela organização em malha e pela possibilidade de sempre ver os limites físicos da obra. Além disso, não é tão difícil de perceber, depois de alguns poucos minutos de observação, que a relação cheio-vazio nas paredes do corredor e a de ondulação do chão é bastante diferente nos dois

147. SAEHRENDT, Christian. "Holocaust Memorial".

The Burlington Magazine, v. 147, dez. 2005, p.844.

148. RUYTER, Thibaut de. "Peter Eisenman's

Pemorial to the Murdered Jews of Europe". A

Press, n. 317, nov 2005, p.41.

sentidos - Norte-Sul e Leste-Oeste - o que também me ajuda no esforço de localização e navegação. Do ponto em que estou agora, eu poderia planejar com alguma segurança uma caminhada até um destino definido, pois contaria sempre com referências para corrigir os desvios de rota. Por outro lado, seria quase impossivel determinar o ponto exato em que me encontro. Mesmo avistando ali no fundo a embaixada americana, não tenho como saber com exatidão em que ponto do corredor estou e, muito menos, por qual deles caminho. Se esquecesse a minha mochila aqui, teria grandes dificuldades de encontrá-la novamente. A indistinguibilidade entre as estelas e entre os corredores certamente é responsável por isso. A desorientação, neste caso do Memorial, se dá denro de um campo definido, dentro de certos limites e através da rígida ordem do grid. Da mesma forma, a dimensão da obra é uma das características responsáveis pelo estado de imersão e de isolamento da cidade no qual se encontram aqueles que passeiam pelos longos corredores escuros, estado que difere muito daquele em que estaria uma pessoa perdida em um labirinto. No labirinto a concepção do espaço está baseada na criação de um efeito de desorientação nos seus visitantes que, por sua vez, guiam o tempo da experiência à compreensão do problema, à decifração do enigma. Tudo se resume a um jogo no qual o labirinto quer confundir e o visitante quer compreender. No Memorial, por outro lado, o estado de imersão não está necessariamente relacionado com o de desorientação e, ao contrário do labirinto, não há entradas ou saídas, mas uma centen de ruas indistinguíveis levando a tantas outras, sem qualquer objetivo ou função que não a de simplesmente se percorrida. No memorial não há começo, meio ou fim, não há charada a ser desvendada, não há motivo para cálculos lógicos. 0 que há é frieza das pedras e o vazio por onde caminhamos. 
Um mar de elementos indistinguiveis. Entretanto, cada peça tem uma posição, uma altura e inclinação defınidas em projeto: praticamente nenhuma peça é igual a outra. Apesar de aparentemente simples, repleta de elementos reprodutíveis, de procedimentos e soluções construtivas padronizadas, a obra do Memorial foi complexa e trabalhosa, exigindo extremo rigor desde a fabricação das estelas até o assentamento dos últimos ladrilhos do piso. No documentário Ein weites Feld (Um campo vasto) ${ }^{151}$, obra homônima de um livro de Günter Grass, a documentarista Gerburg Rohde-Dahl flagra certa tensão em um grupo de operários que instalavam um dos monólitos.

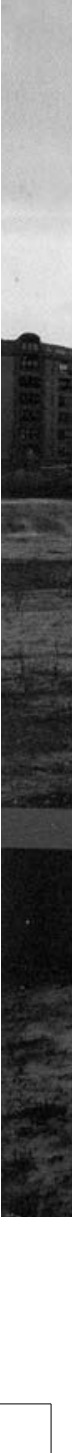
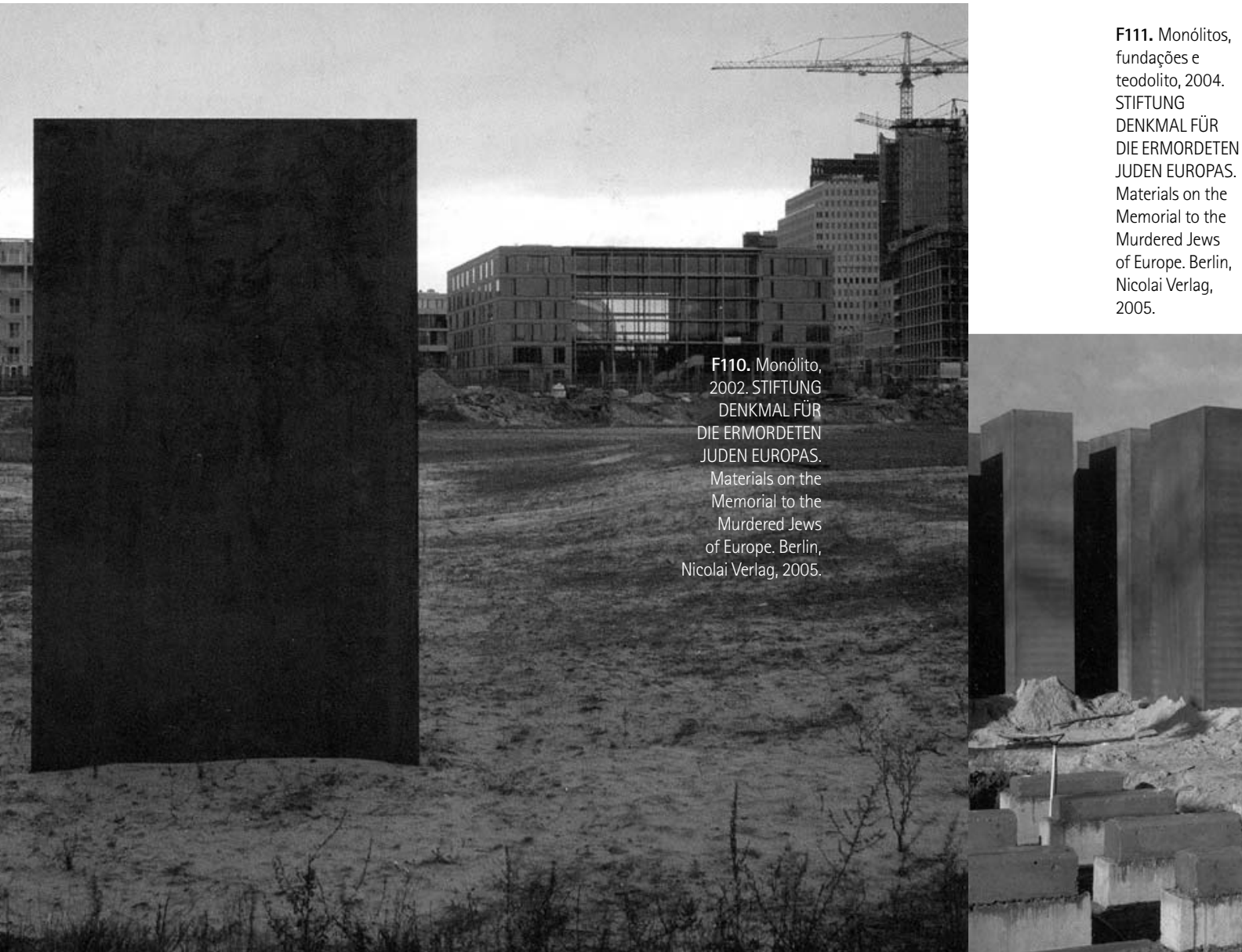

- Vamos acabar fazendo isso três vezes de qualquer maneira... Fica na frente da câmera para esconder isso! Fica ai!

Aproximando-se do grupo, a documentarista aborda um deles perguntando qual é o problema principal.

- Este é um assunto interno. Não podemos comentar. Um assunto interno. Muito complicado...

- $O$ que é complicado?

- Eu não vou ser interrogado!

- Eu achei que você seria capaz de me explicar as dificuldades.

- Isso é fácil. A parte difícil é fazer o torto de maneira certa. Adequadamente torto: é isso! Essa é a parte difícil! 0 grupo se desfaz e cada operário vai para um lado, desaparecendo entre as pedras. Já em uma área mais aberta

a documentarista insiste mais um pouco com um dos operários, que responde agora de maneira mais tranquila. - Vou colocar dessa maneira: a ideia de colocar essas placas em um ângulo especifico, um que funcione. - Qual é o maior desafio?

- As placas grandes. Colocar direito essas placas de metros de altura até que o agrimensor fique satisfeito. Nicolai 2005.
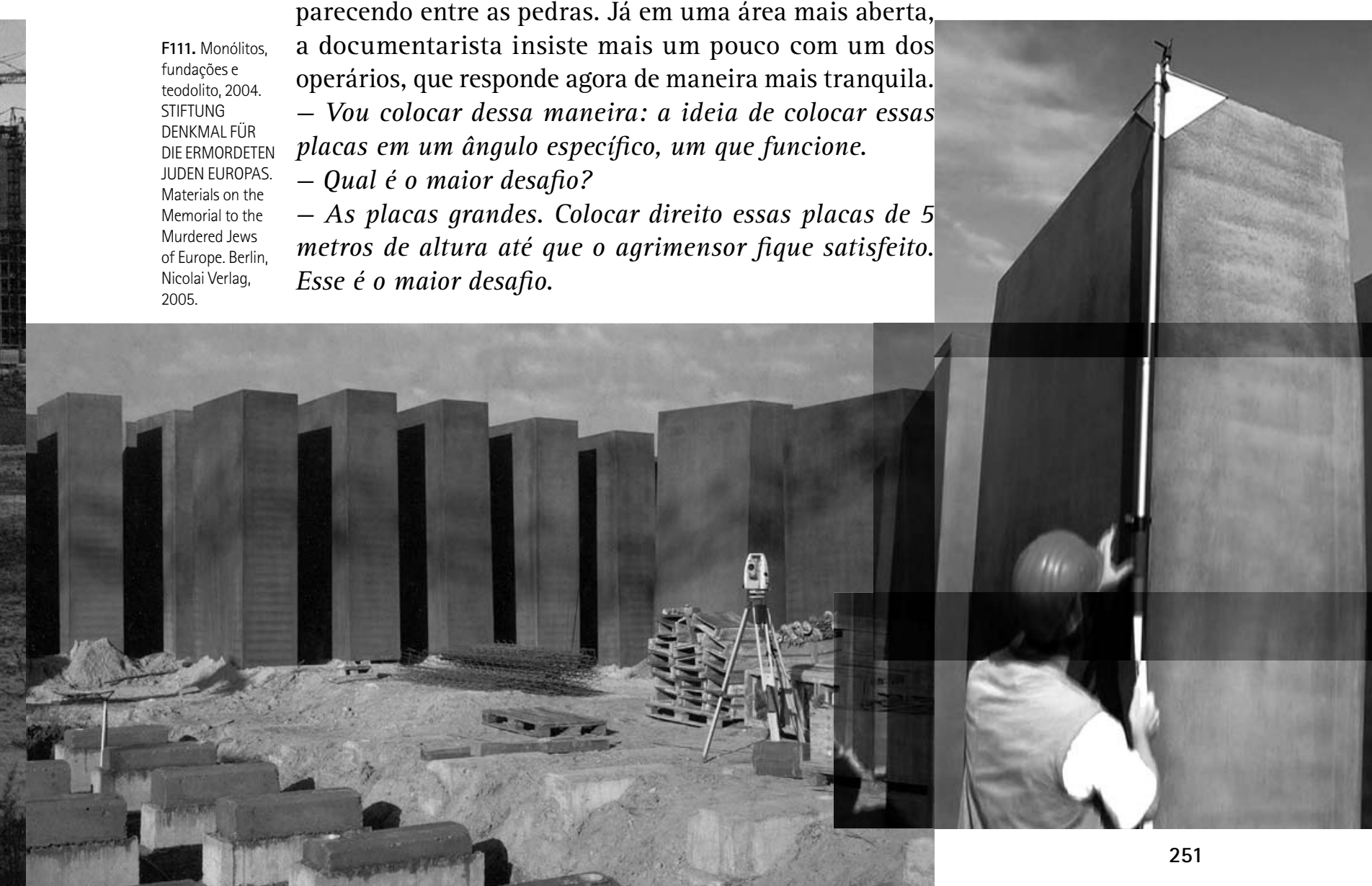
A inclinação das estelas (e aqui a dupla acepção da palavra cai como uma luva), além de ser traço comum a todos aqueles cemitérios antigos a que o Memorial foi comparado - e que ao longo dos séculos sofreram com a ação do tempo e com o imperceptível, mas constante movimento em que todas as coisas estão -, pode ter a sua origem pensada além da simples alusão ou da figuração. Sua origem mais provável, juntamente com a da extrema variação de altura, talvez esteja na precariedade do modelo físico feito na primeira etapa do projeto, na escala reduzida da representação e na limitada precisão da operação manual, que se baseou na ação de inserir elementos prismáticos em uma malha regular perfurada.
A imprecisão e extrema variabilidade de inclinações e alturas, talvez seja também resultado de um processo de projeto manual, ou seja, de um pensamento sobre a arquitetura desenvolvido através da - e na - manipulação do modelo, com formulações de hipóteses para problemas formais em diálogo com problemas conceituais, palpite plenamente aceitável tendo em vista o percurso e as convicções dos autores do projeto nessa etapa de desenvolvimento, o arquiteto Peter Eisenman e escultor Richard Serra. E aqui, sendo acidente ou não, mais uma convergência de elementos nas possiveis interpretações, ou seja, a percepção de uma ação, de um movimento: do arquiteto e do artista sobre o modelo, do prisma sobre a malha e do tempo sobre as estelas.

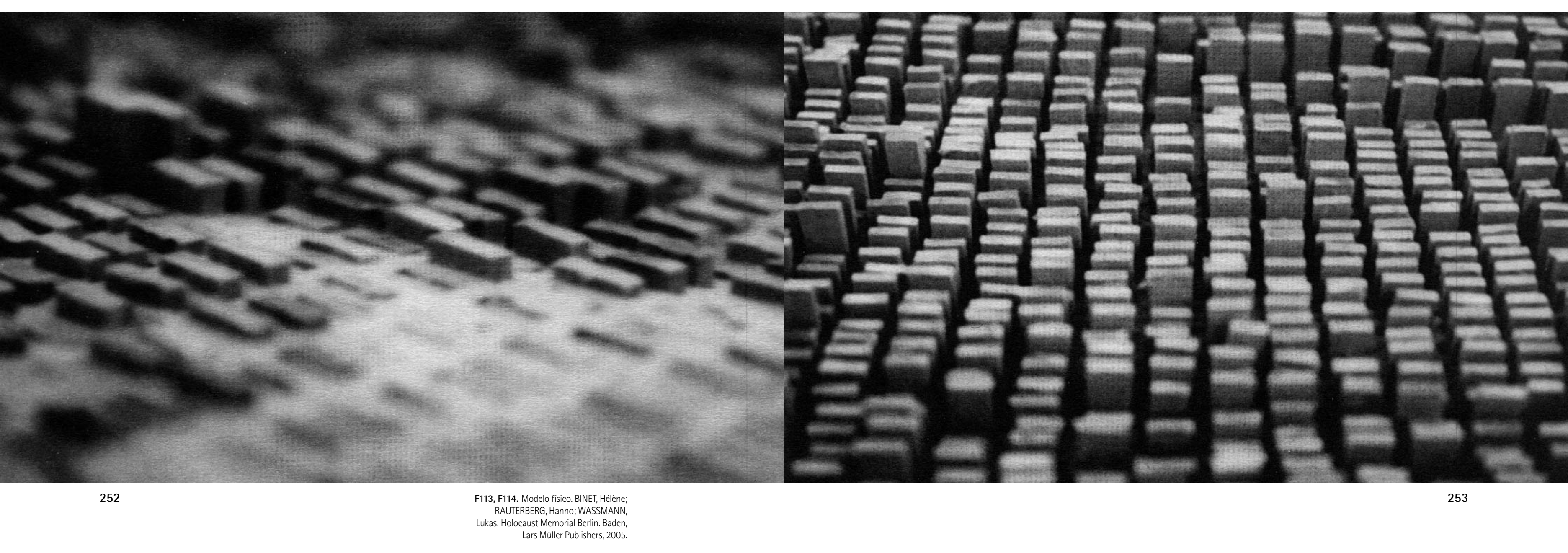


A imprecisão e extrema variabilidade do modelo do concurso, tida como uma qualidade a ser mantida nas etapas posteriores, se transformou na necessidade de extrema precisão e ordem nos processos de projeto e construção. Com o desenvolvimento da proposta e o aumento de definição dos seus elementos visando a construtibilidade, cada monólito, que antes se perdia entre tantos outros cravados da mesma maneira imprecisa na malha perfurada, passou a ter um nome, um endereço e uma descrição física.
0 uso tradicional de eixos nos dois sentidos, embora com um intervalo muito menor do que o usual (resgatando assim a grid com um sentido prático), e de instruções de instalação - que definiam o nome da peça (J16, H42, etc.), o tipo (11 tipos em função da altura) a localização no terreno e as inclinações nos sentidos $x$ e $y$ (variando de $0,5^{\circ}$ a $2^{\circ}$ ) - aliados a um processo industrial de fabricação das peças principais, os monólitos, geraram uma obra extremamente precisa e bem acabada que aumenta em grande grau o contraste com a inclinação e ondulação dos blocos e do terreno.

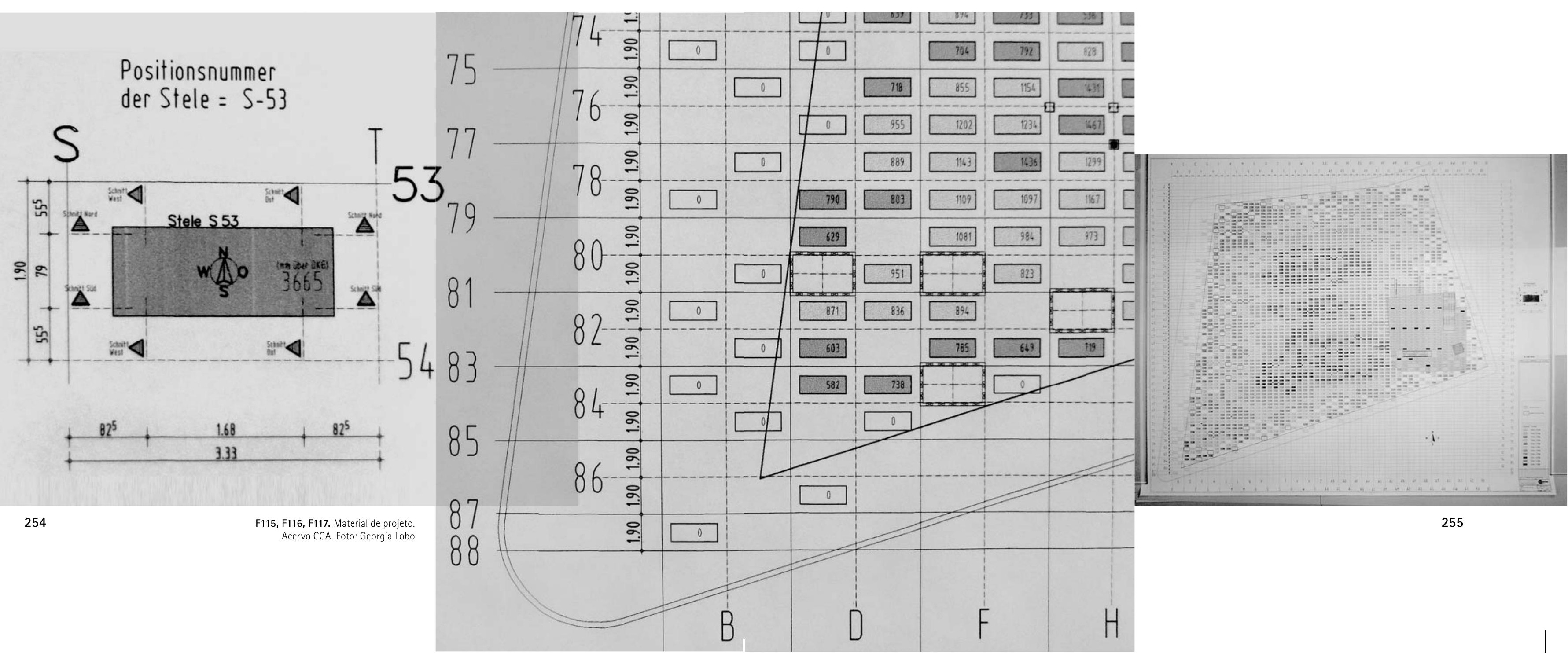


0 uso de ferramentas eletrônicas certamente foi decisivo para a configuração formal da obra. A grande variação de inclinações e alturas vista no modelo físico - resultado da imprecisão do gesto e da escala - foi recriada em modelos eletrônicos. Digitalizados e numerados, os blocos receberam inclinações definidas em cálculos que, curiosamente eram baseados no princípio da aleatoriedade ${ }^{152}$ Assim, é possivel dizer que a inclinação de cada bloco é, ao mesmo tempo, calculada e aleatória. Definir manualmente as características, inclinações e alturas de cada uma dessas pedras, localizá-las no terreno e sistematizar a produção dessa obra seria uma tarefa não impossivel de ser executada, mas certamente um tanto ingrata, caso a obra fosse projetada sem o auxílio de ferramentas eletrônicas. E aqui, um ponto importante: muito provavelmente esse tipo de distinção entre cada uma das pedras, de particularização dos componentes e, sobretudo, de produção racionalizada de uma obra com tantos componentes diferentes, não seria realizada dessa maneira. Muito provavelmente, caso fosse projetada inteiramente na prancheta, ganharia ao longo do desenvolvimento outra configuração. Muito provavelmente a obra se realizaria com outra materialidade.
152. Em uma tensa entrevista dada a Hanno Rauterberg, Eisenman fala rapidamente sobre o uso de ferramentas eletrônicas e da idela de aleatoriedade: "HR: Como o senhor planeja uma coisa como aquela? Uma arquitetura sem sinais, simbolos ou significado? PE: 0 computador foi uma ajuda maravilhosa nesse ponto. Nós o alimentamos com os dados básicos, e depois ele nos devolve duas superfíices bem as combinamos com as estelas Uma das superficies fica sendo o chäo do Memorial, e a a datra mara e a borda superior das estelas. HR: Então, quando estava fazendo o projeto, o senhor passou grande parte do controle para o computador. 0 senhor fez da aleatoriedade um principio orientador. PE: Sim é uma possibilidade de fugir das ideias tradicionais da arquitetura e produzir algo diferente. Veja, é a singularidade, a diferença que me interessa. HR: 0 senhor procura a originalidade em muitos dos seus projetos. Quer sempre desapontar todas as expectativas e construir algo indescritivel. 0 senhor fenterra seus prédios, deixa figuras e superficies se misturarem, gosta de perturbar - fazer tudo como dai? Vocé acha isso inadequado, dado o tema do Holocausto? HR. Poderia ser, com toda certezz. PEE Você pensa que minha busca pela originalidade é uma espécie de fetiche, mas está enganado neste ponto. Meus principios podem se principalmente os mesmos - eu tento me afastar das tipologias usuais, e quero acabar com a ideia de que um prédio deve sempre ter quatro paredes - mas todos os meus projetos têm aparência diferente e geram experiências diferentes. 0 mesmo acontece comigo. 0 Memorial é também um projeto inteiramente distintivo, mesmo que o seja apenas no terreno biográfico" RAUTERBERG, Hanno, EISENMAN, Peter. "Peter Elisenman:e a diversidade, a diferençca, que me interessa".

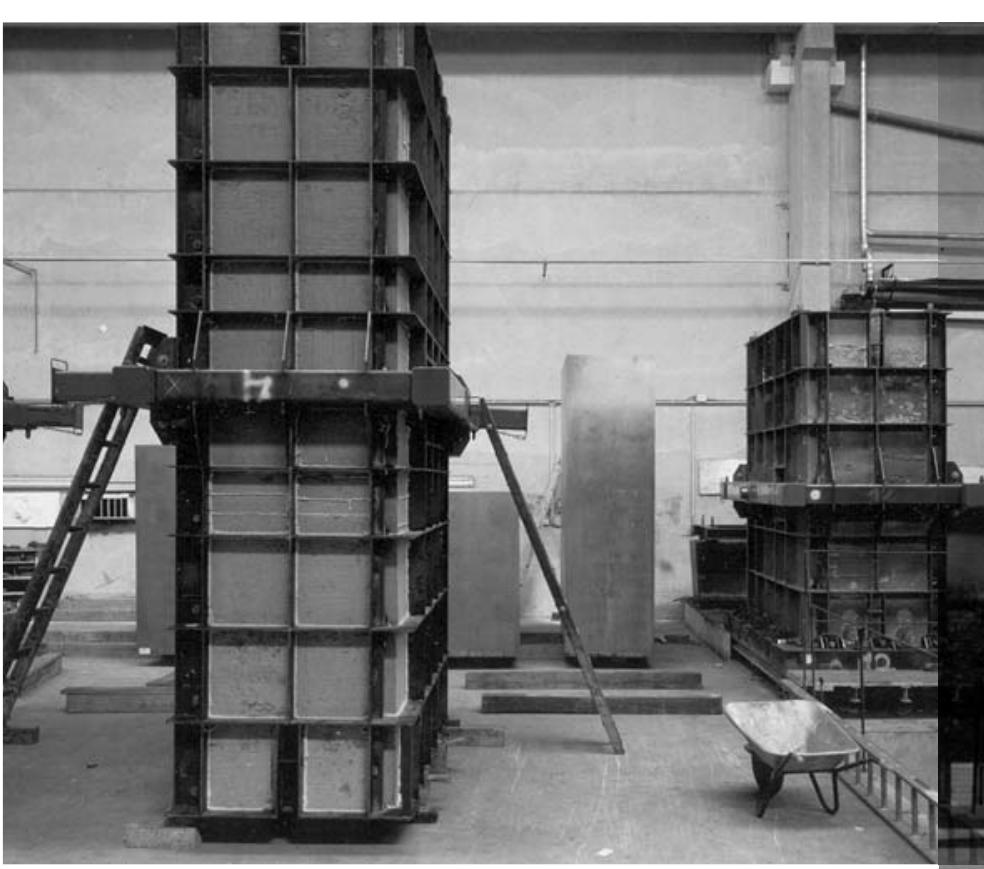

256
F118. Fôrmas metálicas. STIFTUNG DENKMAL FÜR
DIE ERMORDETEN JUDEN EUROPAS. Materials on the Memorial to the Murdered Jews of uurope. Berl Nicolai Verlag, 2005.

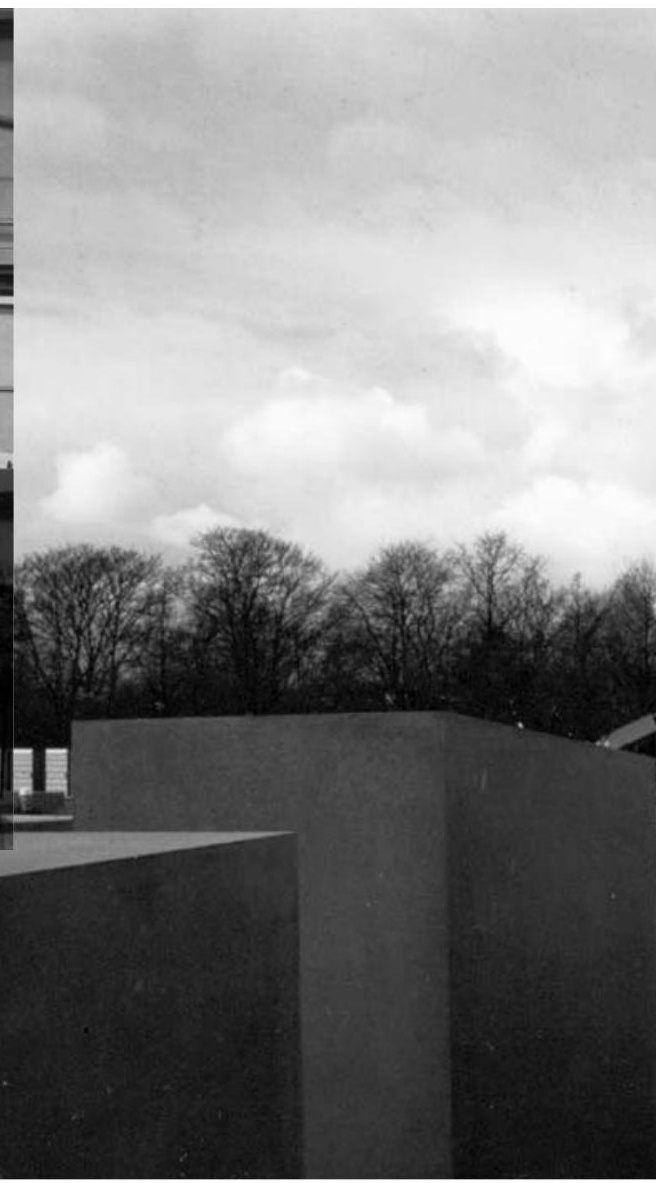

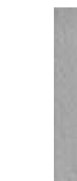


De repente, vindo de algum lugar do lado sul do memorial, um grito agudo que emenda em risos. Em poucos minutos, algo parecido com um efeito em cadeia, o silêncio se converte em uma sequência de gritos, risos e reverberações de passadas apressadas cuja fonte se desloca de um lado para o outro se espalhando e, aparentemente, contaminando todo o Memorial.

Vejo os italianos novamente, dessa vez não mais conversando, mas em uma acalorada perseguição. Mais adiante, o casal de coreanos ensaia meio sem jeito o começo de uma brincadeira. 0 campo de estelas se transformou em um imenso parque de diversões.

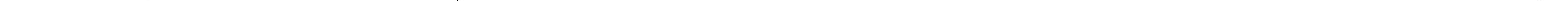


Hoje ela está comigo, mas não andamos um ao lado do outro, pois a largura do corredor não permite. Ela vai à minha frente e eu vou logo atrás. Apesar de tudo, vejo graça na brincadeira que está por toda parte e, para não ser o rabugento da história, resolvo também experimentar. Desacelero um pouco os meus passos, deixando que ela se afaste pelo menos um metro para, de maneira silenciosa e, na medida do possivel, ligeira, dobrar o corredor para tentar despistá-la. Essa tarefa exige de mim não apenas correr, mas também supor o trajeto que ela fará para tentar me encontrar. Não haveria a menor graça em despistá-la de fato, em sair correndo e desaparecer por alguns minutos, então resolvo surpreendê-la armando uma tocaia. Dobro mais uma esquina para dar a volta em um par de estelas enquanto ouço os seus passos atrás de mim: preciso de mais velocidade. $\mathrm{Na}$ minha estratégia instantânea, e correndo mais do que antes, decido dar mais uma volta para poder armar melhor o bote, mas minha manobra fracassa e acabo sendo eu o surpreendido, pois ela me esperava escondida atrás da face menor de uma das estelas. Rimos.

Tocados por uma ponta de vergonha e talvez também por um pouco de culpa, nos calamos e seguimos na caminhada: estamos no Memorial dos Judeus Assassinados da Europa.
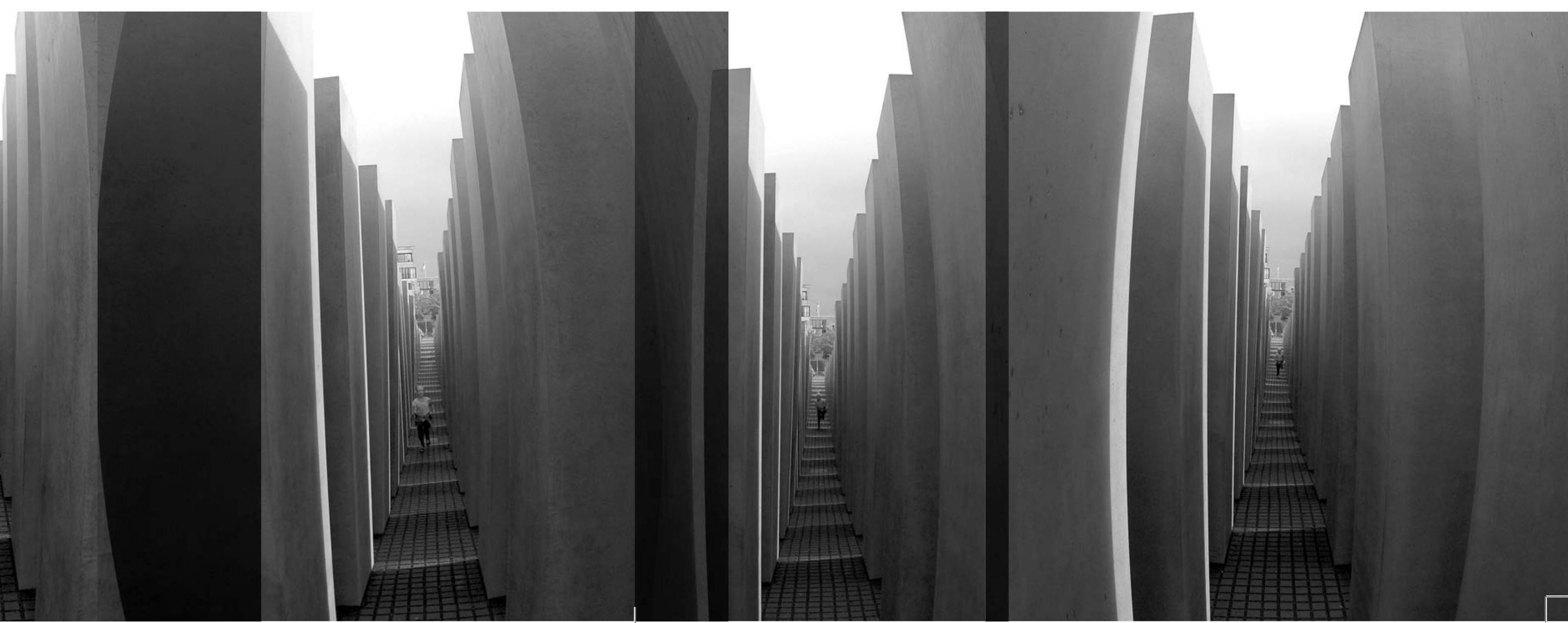
Estou seguro de que o Memorial não funciona como um labirinto, de que não há a possibilidade de que eu me perca aqui dentro. Nos diversos dias em que vaguei sozinho pelos corredores com minhas câmeras fotográficas e meus pequenos cadernos de desenho, não pude experimentar aquele sentimento de completa desorientação que eu esperava encontrar - e que inicialmente busquei -, mesmo submerso por horas e sem me aproximar demais das margens. Sempre contei com a visão da cidade no final dos corredores, com a diferença formal entre os sentidos Norte-Sul e Leste-Oeste e com a extrema ordem da malha, que me garantia um elemento de certeza. É impossivel se perder aqui dentro. Mas depois de ensaiar com ela o começo de uma brincadeira, percebo que não apenas seria fácil desaparecer da sua vista, como também, perdê-la por completo da minha. E impossível se perder aqui dentro, mas é muito fácil se perder de alguém. Pela dimensão desse campo, pela ausência de portas, de entrada ou saídas, pela impossibilidade de ver ao mesmo tempo mais do que dois compridos corredores, percebo que aqui dentro o controle que tenho sobre o espaç diz respeito apenas ao meu próprio corpo. A extrema ordem desse campo, a pequena largura dos corredores e o efeito de imersão a que voluntariamente os visitantes se submetem, induzem à dispersão, à caminhada solitária Aqui todos estão submetidos à mesma ordem, ao mesmo conjunto de relações formais que parecem induzir seus comportamentos dentro do campo. A forma que garante a brincadeira de esconder e pegar, deve ser motivo de desespero para algumas mães com seus filhos pequenos. Vê-los desaparecendo entre as pedras escuras ao descer correndo as ladeiras, ouvir as risadas sem poder ver seus rostos, percorrer apressadamente os corredores olhando a cada transversal, e, não os ouvindo mais e sem conseguir encontrá-los, volta correndo para uma das margens para tentar uma impossível visão panorâmica que esbarra na dureza das pedras, restando apenas esperar pelo seu reaparecimento.

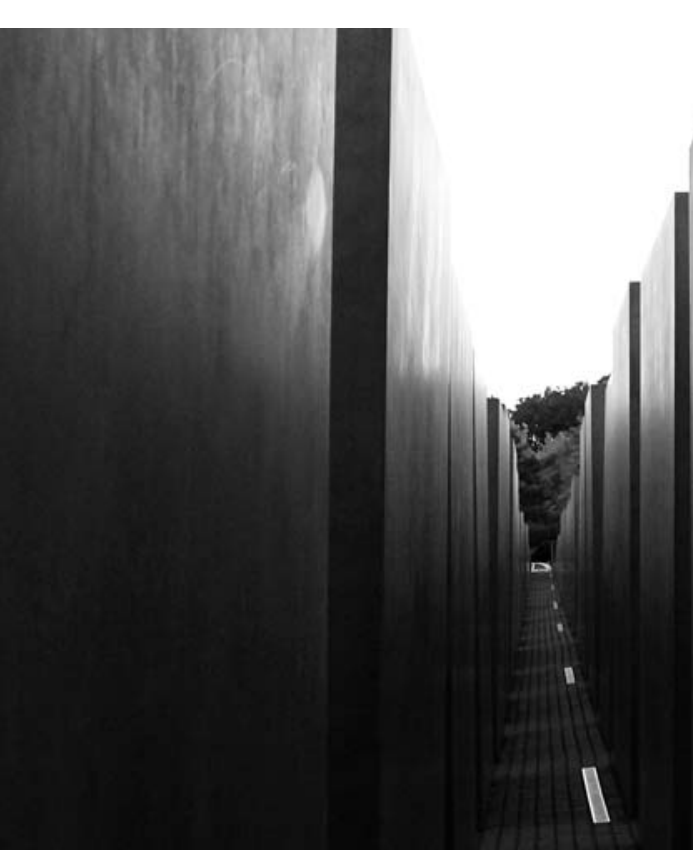


Como mero exercício, e sem a pretensão de chegar a uma conclusão muito relevante, listei algumas das ações executadas na brincadeira mais comum aqui embaixo. Olhando a lista de verbos e abertura que eles têm ao serem escritos na brancura e frieza do papel sem que junto com eles venham necessariamente as faces alegres e ruborizadas que os executavam, penso nesse significado acidental que o Memorial ganhou, ou seja, o uso como um imenso campo para diversas imenso campo para diversas
brincadeiras. Talvez ele não seja tão inconveniente assim do ponto de vista do nebuloso objetivo proposto na sua construção, ou seja, o de lembrar as vítimas do Holocausto.

despistar

esconder

procurar

espreitar

perseguir

encontrar

alcançar

agarrar

assustar

gritar 
Essa gritaria toda já me deixa um pouco cansado. Meus ouvidos, depois de um dia inteiro, se saturaram até o limite da irritação. 0 grito desse moleque bem atrás de mim enquanto eu filmava (e o susto) foi a gota d'água para a minha infinita paciência oriental. $\beta^{*} \#{ }^{\circledR} @$ ! Resmungo olhando feio. Com um olhar e um andar insolente e desafiador - que só um adolescente de 15 anos é capaz de fazer - ele ajeita a gola do casaco e percorre calmamente na minha direção a largura de uma estela antes de virar a quase um metro e meio de distância de mim com um leve sorriso no rosto. Foi um erro meu... Não só por não ter o direito de repreender ninguém, mas também porque com isso coloquei mais um elemento no jogo no qual ele e mais cinco garotos da mesma idade estavam empenhados há horas em jogar. Assim, de obstáculo no tabuleiro passei a ser uma das metas. Caminhando em corredores paralelos ao meu, os seis moleques passaram soltar pequenos gritos que, aparentemente, tinham o objetivo de me testar. Vocês venceram, e por antecipação: não quero jogar. Volto à calçada para ver o final do dia. 
76. Já um pouco cansado de todas essas horas de vertigem percorrendo os corredores - intencionalmente fugindo das bordas - volto à superfície para um descanso. Subo por um dos corredores até o lado norte num aclive bastante suave. Aos ruídos dos meus passos, misturam-se novamente muitos outros. A maneira gradual com que isso acontece permite que eu possa distingui-los, conseguindo dedicar alguns poucos segundos de atenção a cada um que surge até que o volume de outro se sobreponha aos demais. Estou quase na calçada e o estado de normalidade se reestabeleceu: todos os sons ao mesmo tempo.

77. Placa preta de vidro no chão na calçada da Cora Berliner Straße:

Regulamentos para visitantes.

1. Ao longo do ano, o risco pela entrada no campo de estelas é do indivíduo.

2. Sem exceções, a entrada no campo de estelas só pode ser feita vagarosamente e a pé. Há 13 vias que são acessiveis a cadeiras de rodas adaptadas a visitantes com deficiências de mobilidade.

3. $O$ que segue, não é permitido: Barulho de qualquer tipo,

Pular de uma estela para outra;

Trazer cachorros ou outros animais de estimação para o campo:

Trazer e estacionar bicicletas ou equipamentos similares;

Fumo e consumo de bebidas alcoólicas.

4. Os visitantes são solicitados a seguir todas as instruções dadas pelo

pessoal de segurança autorizada.

Fundação Memorial dos Judeus Assassinados da Europa. 
Muita gente sentada, uma garota deitada tomando sol (aparentemente na vã esperança de conseguir um bronzeado), vários grupos reunidos na sombra das árvores plantadas junto à avenida do parque, aproximadamente vinte pessoas em círculo ouvindo as explicações dadas por um guia com o crachá da fundação criada para administrar o Memorial. Bicicletas cheias de propagandas dobrando a esquina em fila, dois seguranças da embaixada. Viro.
Uma turma de adolescentes na crista da onda mais alta tirando fotos de si mesmas. Trocam de posição, ajeitam o cabelo, mandam beijos para a câmera, ensaiam outros enquadramentos: de baixo para cima, de cima para baixo, em grupo esperando a contagem do timer. De repente, os sorrisos se vão e olham sérias para baixo prestando atencão a algo que eu não vejo daqui. Todas ao mesmo tempo, recolhem a parafernália fotográfica em suas bolsas, as sapatilhas e sombrinhas, e parafernália fotográfica em suas bolsas, as sapatilhas e sombrinhas, e
começam a descer para a margem pulando com cuidado de pedra em pedra. Outros pequenos grupos e aventureiros solitários começam a fazer o mesmo e, em muito pouco tempo, a superfície ondulada das estelas está novamente vazia. Vejo lá embaixo, andando no corredor à minha frente, a figura pouco ameaçadora de um senhor calvo de
bochechas rosadas: sapato de borracha, calça social e jaqueta esportibochechas rosadas: sapato de borracha, calça social e jaqueta esporti-
va azul marinho, camisa branca, gravata listrada, um guarda-chuva fechado em uma mão e um walkie-talkie na outra, e, na lapela da

jaqueta, um enorme crachá.
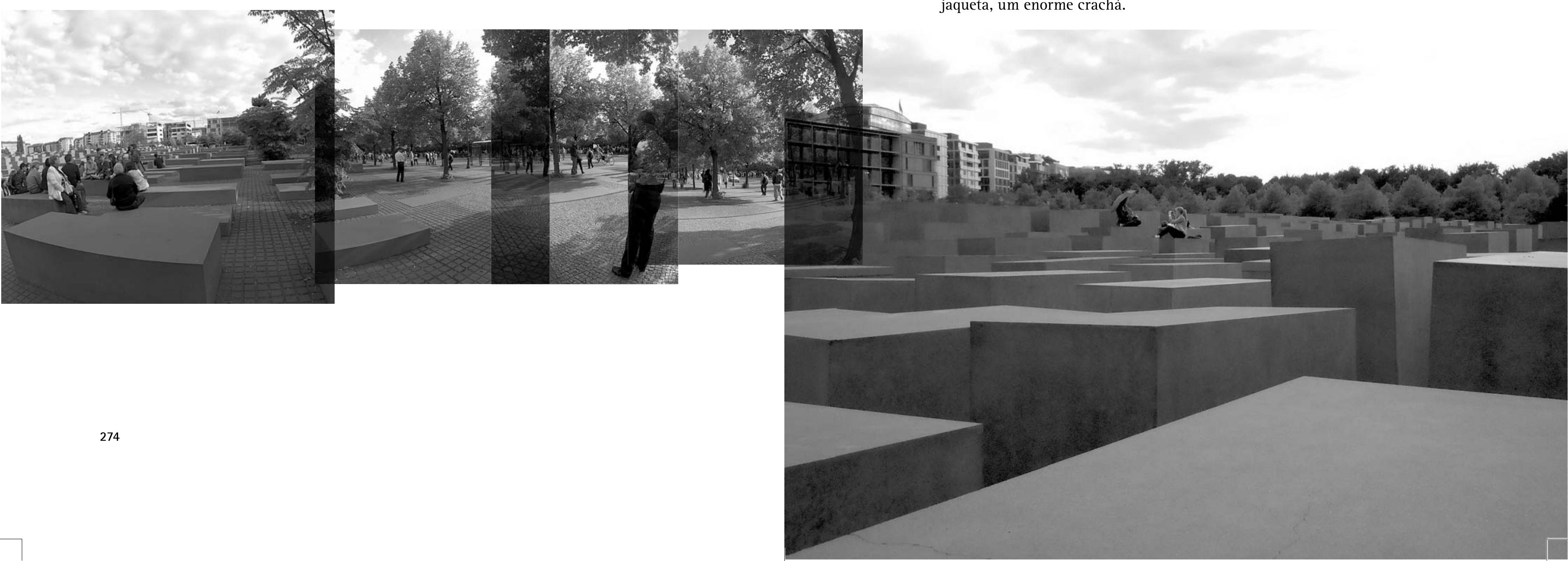


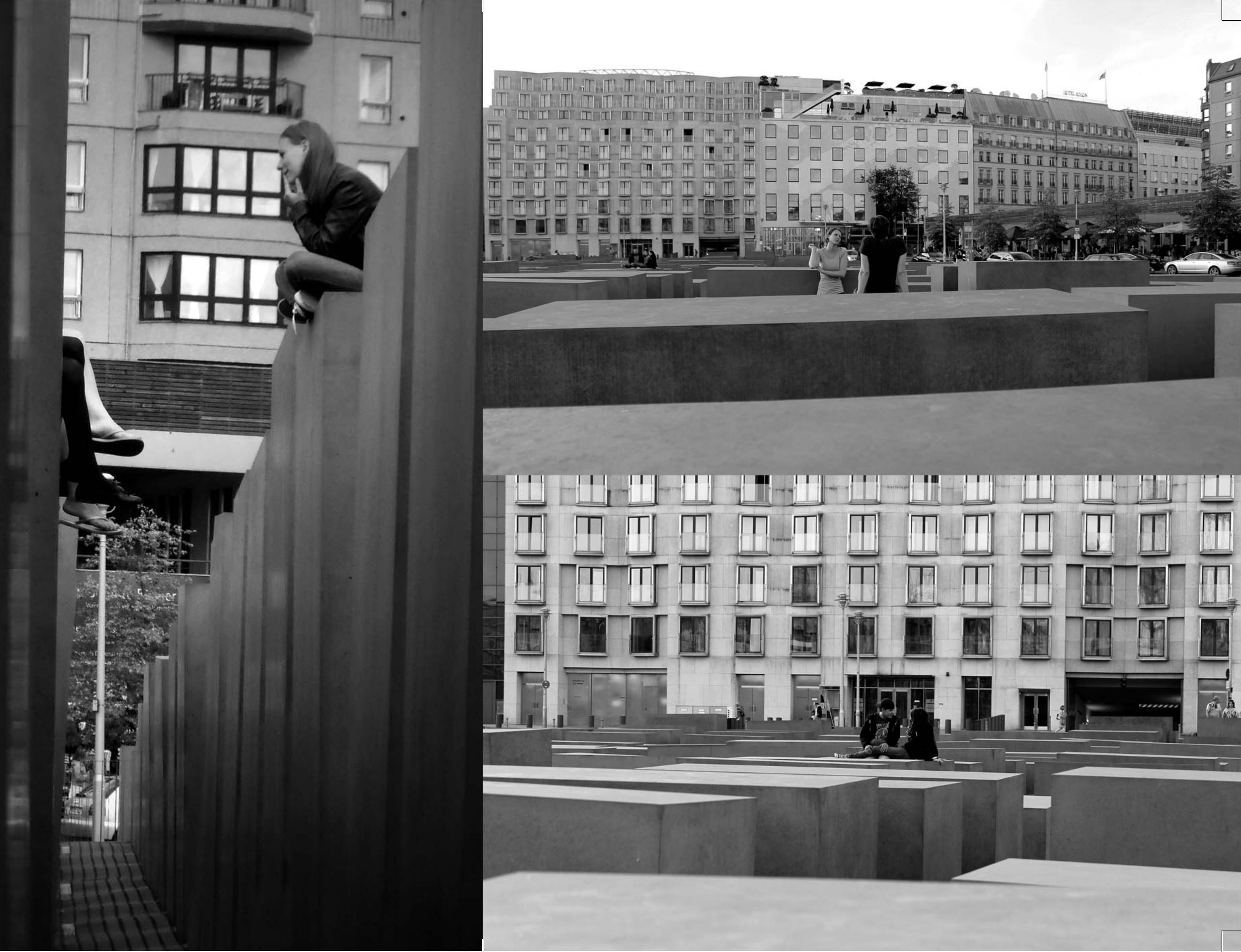


Vendo a aproximação do guarda, o menino se deita no topo de uma das estelas. Espera um pouco e se diverte percebendo que escapou da vista do estraga prazeres. Após alguns segundos, se levanta e continua com seu esporte radical, que agora envolve não só pular de pedra em pedra para vencer os abismos de até cinco metros de altura, como também enganar a autoridade. Voltando à margem para ter a visão da superfície, o guarda mira novamente o garoto, mas como a ordem para descer não pode ser dada de lá mesmo, pois feriria 0 parágrafo primeiro do item três das regras de uso do Memorial dos Judeus Assassinados da Europa, mergulha novamente tendo na cabeça a localização do meliante. Mas o garoto tem ampla vantagem. Tem os superpoderes conferidos pelo grid. Enquanto o guarda é obrigado a seguir pelos corredores, caminhando sempre no sentido Norte-Sul ou no Leste-Oeste, ele é livre e pode saltar de pedra em pedra em

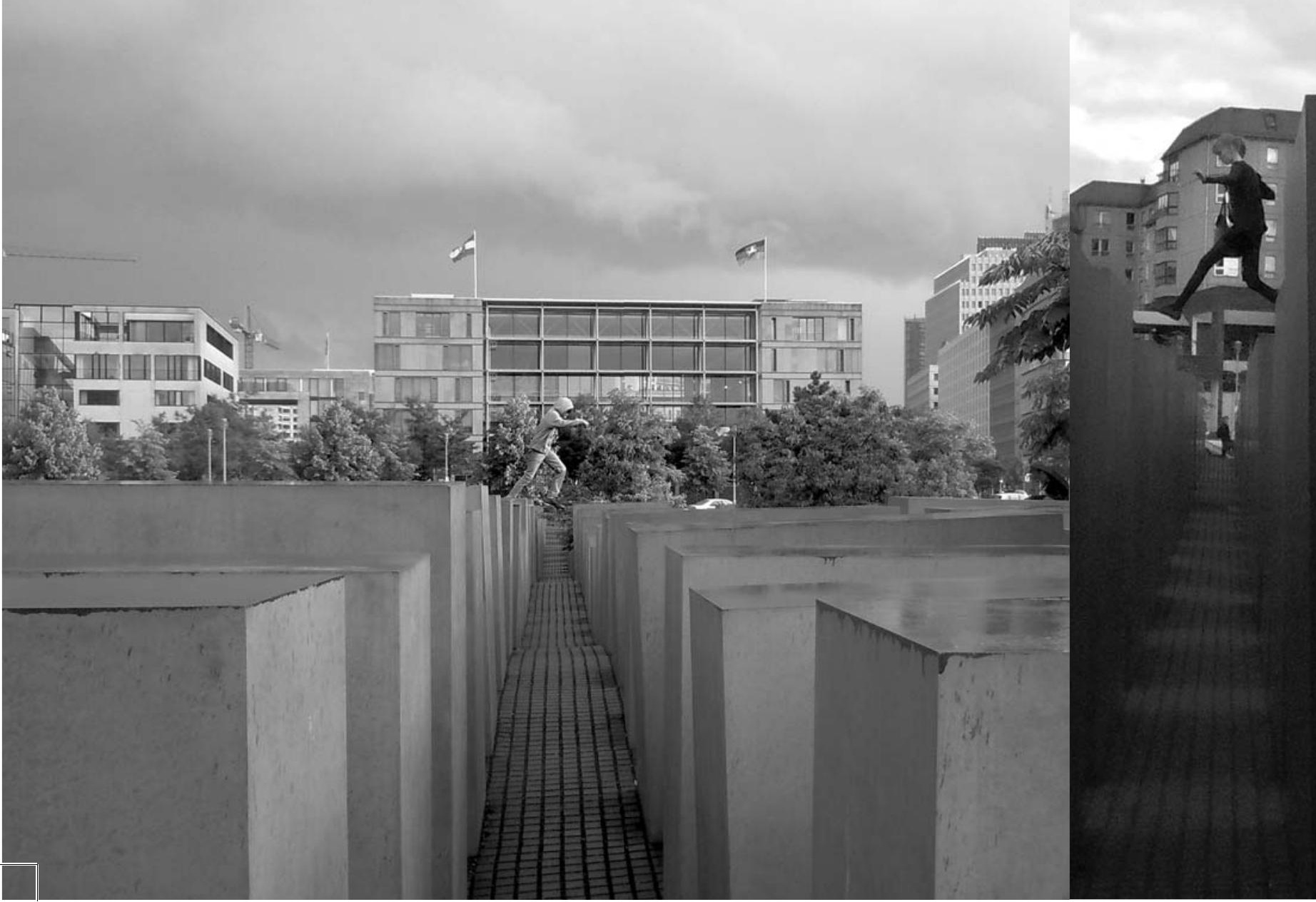

qualquer direção, desenhando diagonais, curvas, elipses, ziguezagues, ignorando não só as regras do espaço, como também as convenções que dão forma a ele. Só mesmo aqueles desavisados para serem pegos. De olho no seu adversário, espera a visão do guarda ser encoberta pela altura das estelas para inverter o sentido da trajetória de saltos que efetuava quando foi flagrado. 0 garoto é o grande vencedor de mais uma rodada.

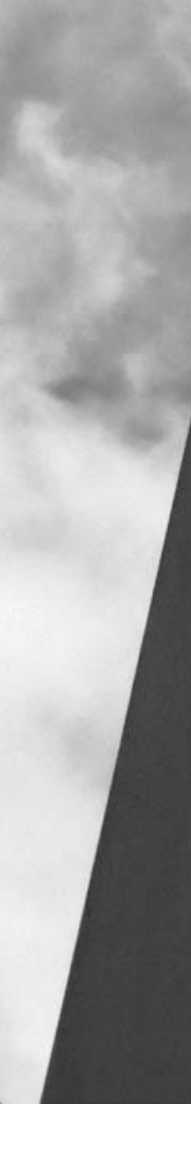




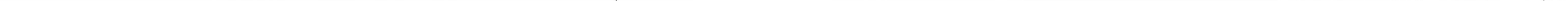


Sentado aqui na margem, observo a superfície formada pelo topo das estelas novamente vazia, assim como a encontrei de manhã. Há pouco densamente povoada pelos mais diversos usos, quase todos proibidos, a superfície agora reivindica a atenção para a sua face. Restam poucas pessoas aqui nesse final de dia. Os ônibus turísticos já não chegam mais. Os visitantes que restaram estão todos, assim como eu, calmamente sentados na margem vendo a obra ser banhada com a luz alaranjada do sol que, entre as nuvens, começa o lento movimento de descida até o horizonte. Meus olhos não veem esse movimento descendente, mas isso não me impede de enxergá-lo. Isso talvez se dê porque a percepção e compreensão desse fenômeno se dão no tempo, tendo como base aquilo que eu havia percebido antes. Da mesma maneira talvez se dê a percepção de movimento em algo tão estático como essas pedras de concreto. Como posso ver nesse campo de pedras algo similar a uma superfície de água perturbada por algo nela arremessado ou a um terreno sob efeito de abalos sísmicos $^{153}$ ? Ver uma onda na variação de alturas de cada estela é como ver o movimento de um cavalo em uma fotografia: aquilo que vemos é tomado pelo significado daquilo a que se associa.

153. Em alguns trabalhos de Maya Lin, como o "The wave field", assim como em obras de Alberto Burri, encontramos fortes elementos que reforçam essa associaçáa. No caso deste ultimo, suas telas com superficices fraturadas pela contraçáa do material usado, como a do fundo de um para a imensa obra em Gibellina, na Itália, um memorial para lembrar dos mortos em um terrivel terremoto.

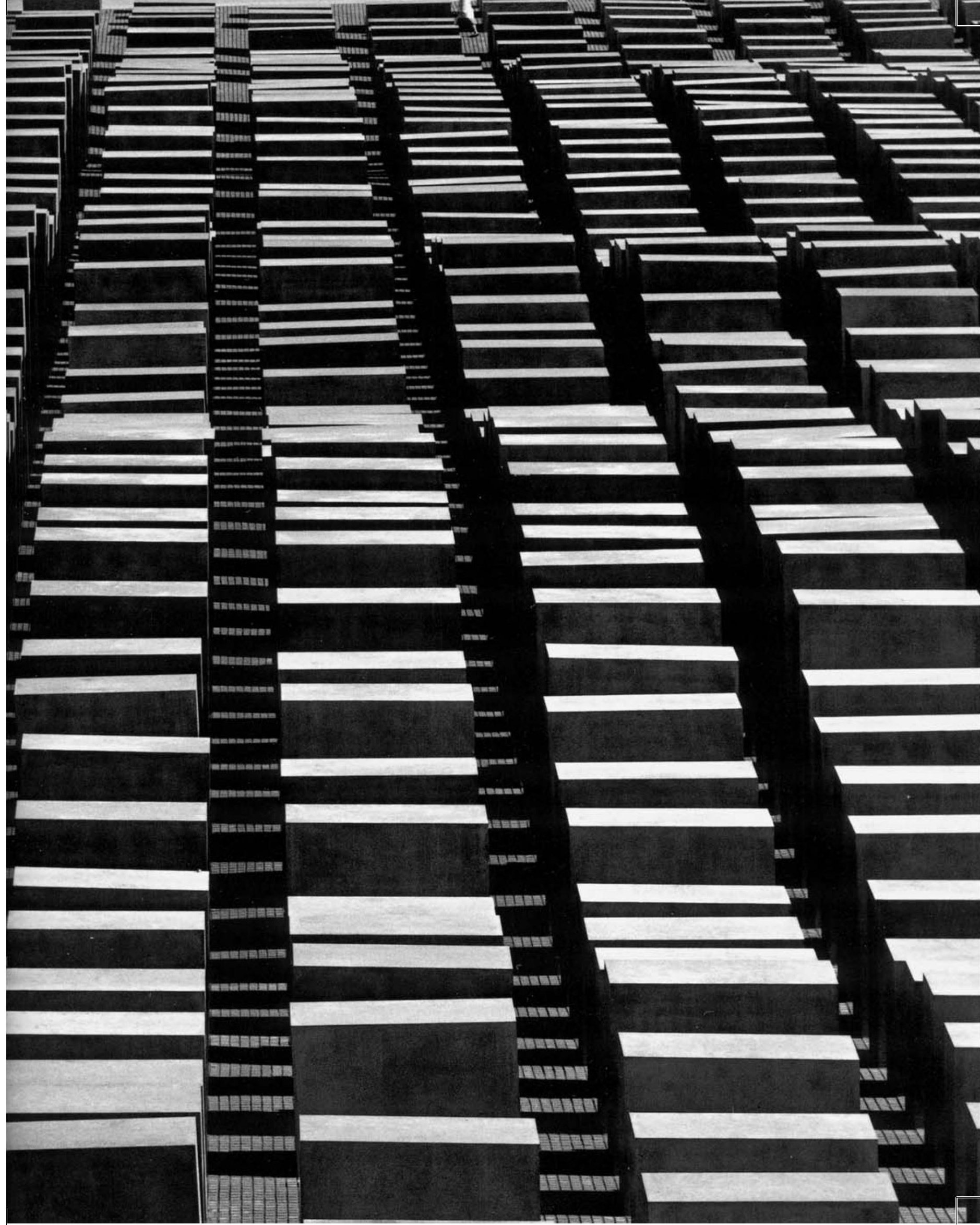


Com o uso de ferramentas tradicionais de desenho de topografia aliados aos estudos com o uso de diagramas gráficos que pareciam analisar a intensidade da perturbação da superfície - trazendo assim um parentesco de primeiro grau com os gráficos desenhados por sismógrafos - e a posterior digitalização do processo, adicionando-se a ideia de aleatoriedade nas inclinações de blocos e no desenho da topografia, a movimentação caótica ganhou ordem e harmonia, formando as ondas bem desenhadas da obra construída que aumentam de forma gradual à medida que se aproximam do centro e de uma das extremidades do terreno. É interessante notar aqui como cada um dos processos percorridos ao longo de um projeto não apenas traduz de uma maneira muito específica o que é trazido das etapas anteriores, moldando o projeto de acordo com as suas possibilidades, como também introduz características da sua própria materialidade e modo de representar.
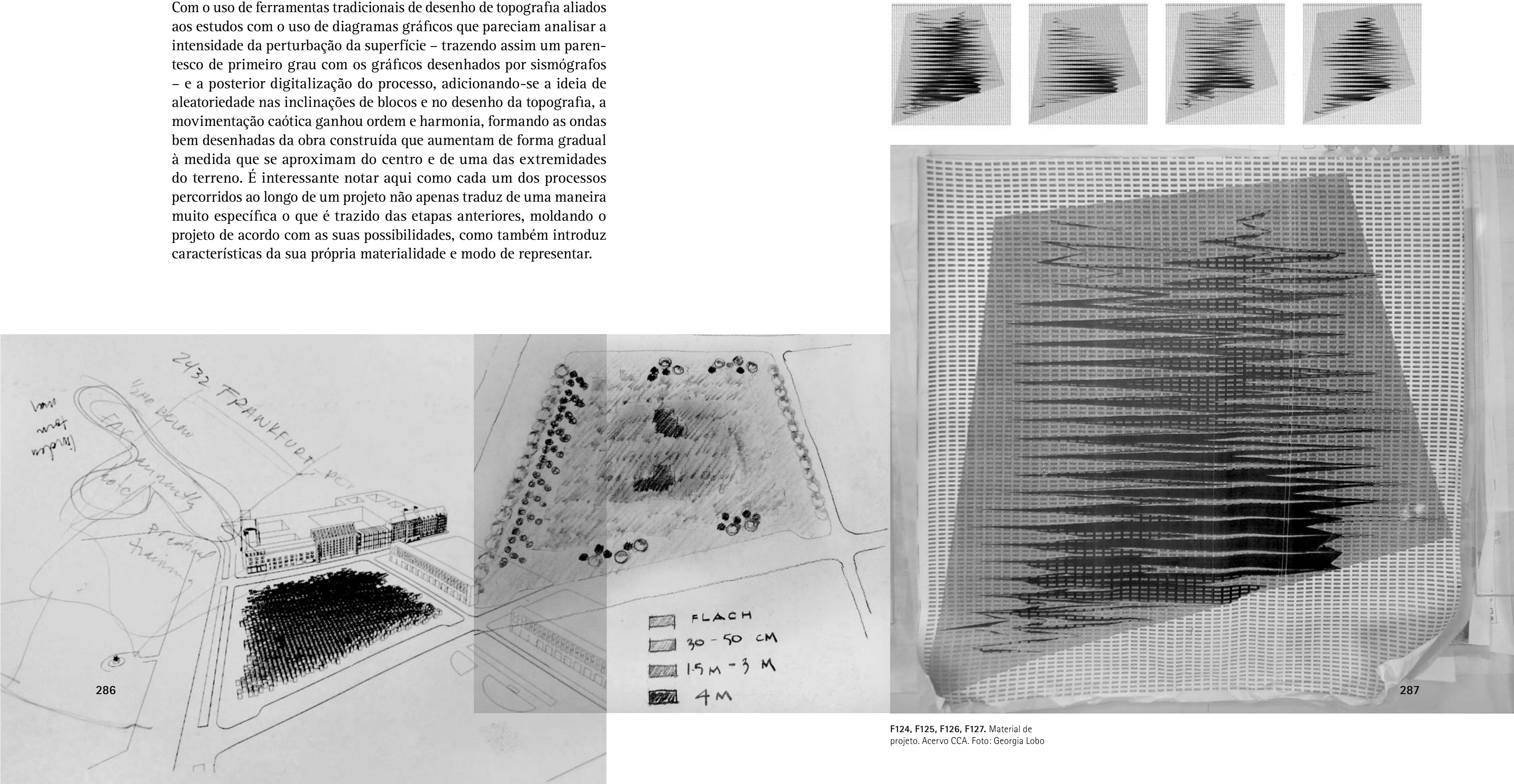

F124, F125, F126, F127. Material de
projeto. Acervo CCA. Foto: Georgia Lobo 


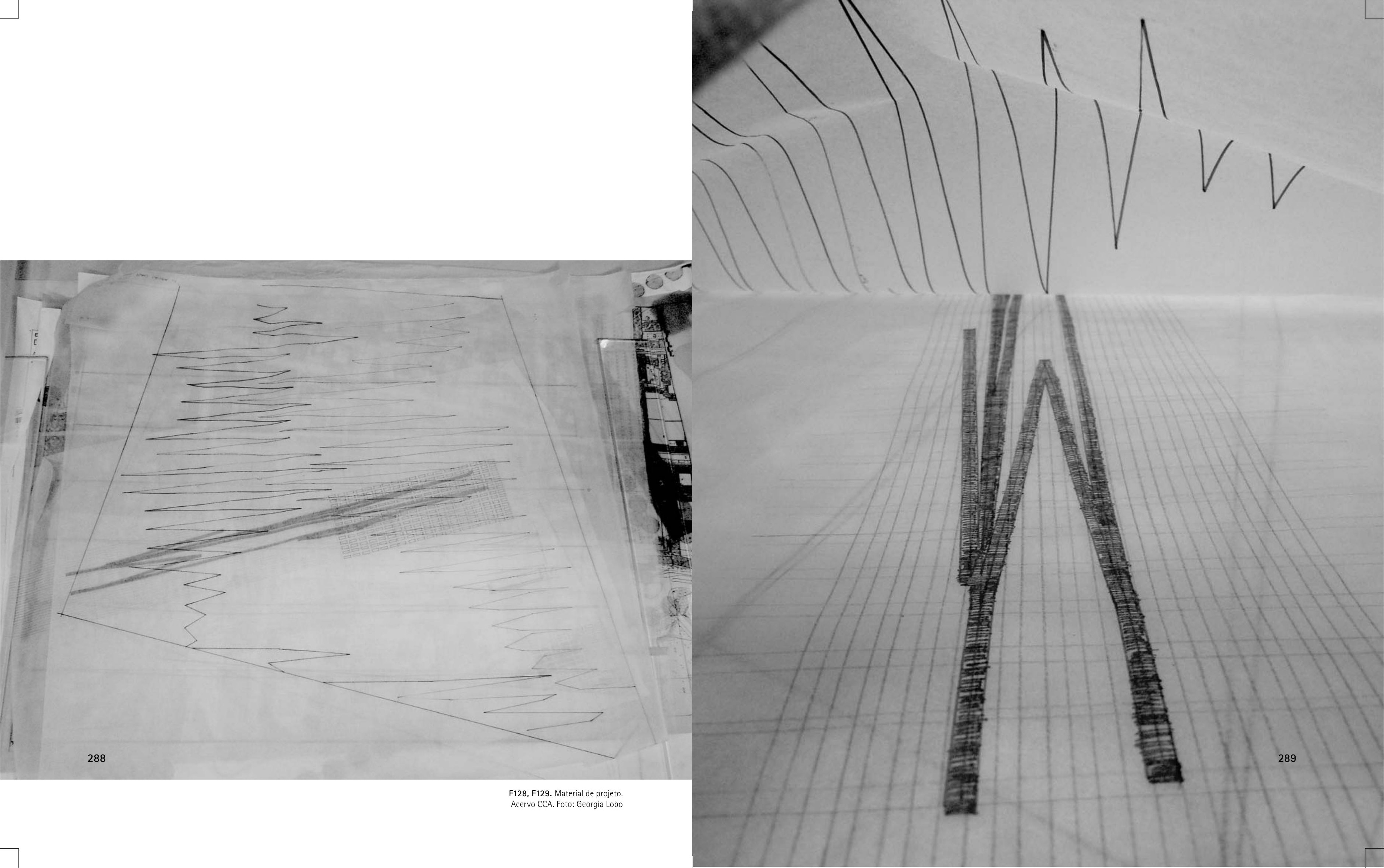



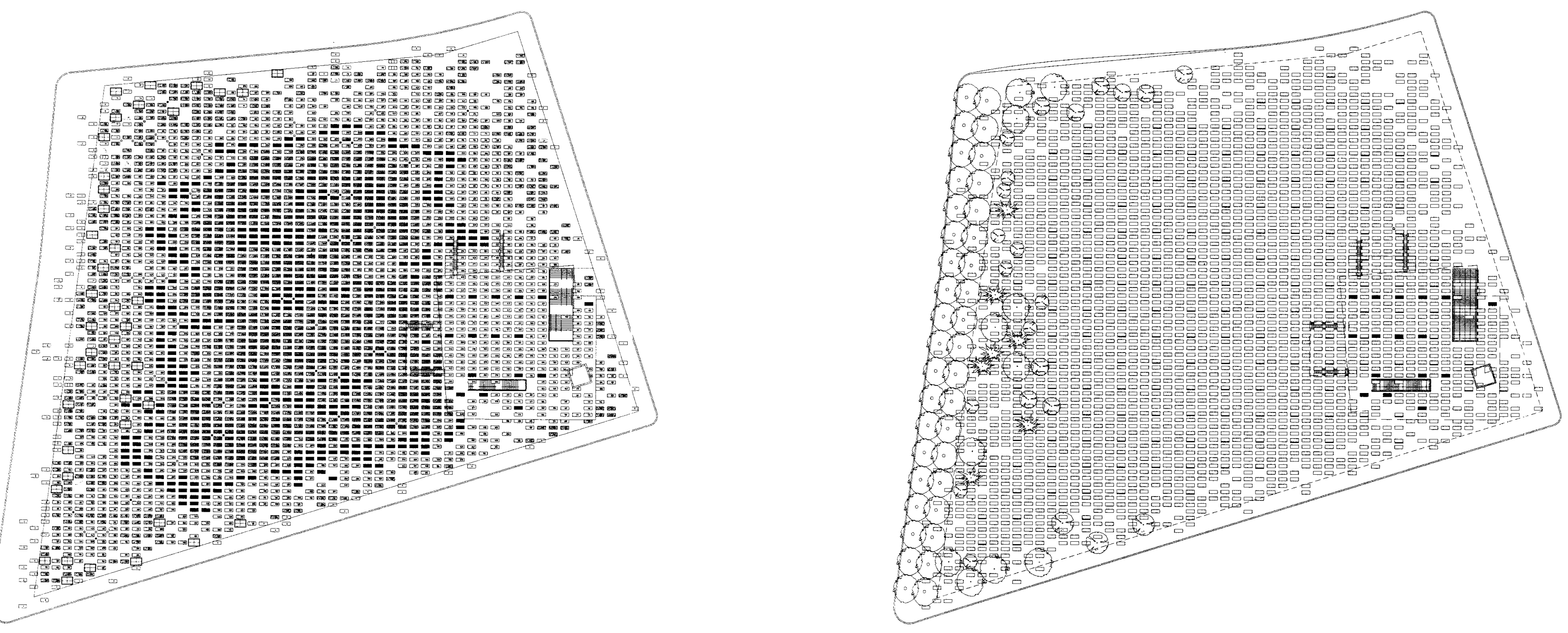
O Memorial ocupa uma área de $19.073 \mathrm{~m}^{2}$ no bairro central de Berlim bem próxima ao Parlamento e aos principais pontos turísticos da cidade. 0 terreno comportaria a implantação de grandes e conhecidos edifícios de Berlim, como o Museu Judaico, o Volksbühne, o Sony Center, ou mesmo, com algum esforço, o Reichstag. 0 Brandenburger Tor e a Pariser Platz ocupam uma área um pouco menor do que a do Memorial. Em uma hipótese absurda, e também com algum esforço de desenho, seria possível até mesmo implantar aqui a Torre Eiffel. É preciso lembrar, entretanto, que a dimensão da obra, ou ao menos da área onde ela se insere, não foi definida pelos autores no ambiente do projeto, mas no ambiente público das disputas políticas, decidida a partir do resultado das negociações entre o governo um grupo de cidadãos. É aceitável pensar que a dimensão da obra seja resultado ou tenha sofrido as reverberações de uma cultura acostumada a produzir tantas realizações monumentais: das colunas de pedra de Karl Friedrich Schinkel no Altes Museum, às de luz de Speer no Zeppelinfeld, da comemoração do triunfo na Siegessäule e no Brandenburger Tor, à da tragédia no Memorial do Holocausto. 0 principal arquiteto nazista, Albert Speer, desenhou uma série de construções a mando de Hitler tendo como principal demanda projetual a monumentalidade: a dimensão como programa. Uma das mais famosas construções projetadas por ele - e que, justamente pela sua dimensão, realizaram uma nova experiência espacial -, a área de desfiles do Zeppelinfeld, se comparada à área do Memorial, coloca mais um ingrediente na polêmica: sua área é mais de seis vezes maior. Outro projeto seu, parte do grande plano de reforma de Berlim que Hitler pretendia executar após ganhar a guerra, 0 Volkshalle, previa uma cúpula com aproximadamente duzentos e cinquenta metros ${ }^{154}$, dentro da qual poderiam ser construídos com folga dois memoriais como esse. Mas qualquer comparação com a dimensão de arquiteturas nazistas se torna desprezivel se o campo de extermínio de Auschwitz for lembrado. Somente um dos principais núcleos do complexo, o de Auschwitz II-Birkenau, somava uma área que correspondia a aproximadamente $1,5 \mathrm{Km}^{2}$, ou seja, mais de setenta e oito vezes maior. Albert Speer, em sua célebre biografia, narra uma fala de Hitler e reflete sobre a dimensão das construções: "No início de 1939, Hitler, em um discurso para trabalhadores da construção civil, justificou as dimensões de seu estilo: 'Por que sempre maior? Eu faço isso para restaurar em cada indivíduo alemão a sua autoestima. Em uma centena de áreas que eu quero dizer para o indivíduo: Nós não somos inferiores, pelo contrário, estamos em pé de igualdade com qualquer outra nação'. Esse amor por grandes proporções não estava apenas amarrado com o matiz totalitário do regime de Hitler. Tais tendências, e o desejo de demonstrar sua força em todas as ocasiões, são característicos da riqueza adquirida rapidamente. Assim, encontramos os maiores edifícios na antiguidade grega, na Sicília e na Asia Menor. E um interessante corolário dessas cidades geralmente governadas por déspotas. Mas, mesmo na Atenas de Péricles, a estátua de Atena Partenos de Fídias tinha quarenta metros de altura. Além disso, a maioria das Sete Maravilhas do Mundo ganhou sua reputação por seu tamanho excessivo: O Templo de Diana em Éfeso, o Mausoléu de Halicarnasso, o Colosso de Rodes, e o Zeus em Olímpia de Fídias. Hitler demandava grandes dimensões, no entanto, envolvia mais do que ele estava disposto a admitir aos trabalhadores. Ele queria o maior de tudo para glorificar suas obras e ampliar seu orgulho. Esses monumentos eram uma afirmação da sua pretensão de dominação mundial muito antes de ele se atrever a manifestá-la, até mesmo para seus colaboradores mais próximos" $" 155$. A comparação com grandes edifícios, praças e monumentos questionando um possível superdimensionamento da obra, ou com a arquitetura nazista, justificando de alguma maneira as proporções, coloca uma interessante questão: Qual seria o tamanho adequado para uma obra que pretende ser a representação da memória do Holocausto? Qual seria a proporção da representação do assassinato de seis milhões de pessoas?

154. SPEER, Albert. Inside The Third Reich. New York, The Macmillan Company, 1970, p.74. 155. SPEER, Albert. Inside The Third Reich. New York, The Macmillan Company, 1970, p.69. Tradução nossa. 


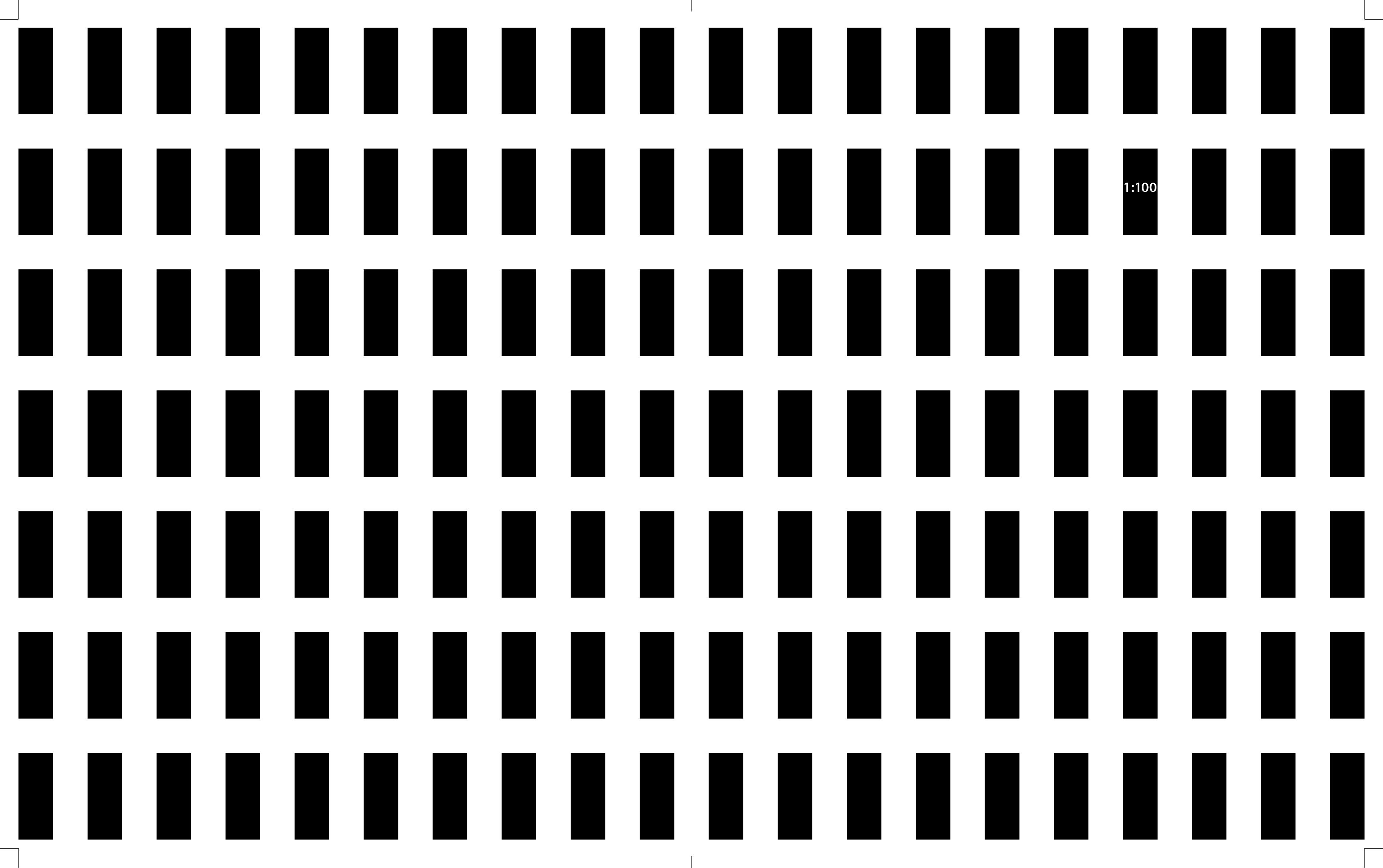



1:1.000.000 
A espantosa dimensão da obra, somada à quantia de recursos públicos destinados à sua construção - quase vinte e oito milhões de euros à sua localização central, bem ao lado do centro de poder alemão e dos principais museus da cidade, participaram da polêmica que marcou todo o processo, envolvendo não somente os realizadores da empreitada - o governo alemão, a associação pró-memorial de Lea Rosh, o arquiteto Peter Eisenman, etc - mas também a imprensa os cidadãos comuns. Rohde-Dahl registrou algumas interessantes opiniões dadas por pessoas que passavam junto às grades que cercavam o canteiro de obras do Memorial, revelando pontos nevrálgicos da obra. Algumas das declarações, que às vezes divergiam entre si, diziam respeito ao incômodo com o tamanho da intervenção:

- "O Memorial é necessário, mas isso passa um pouco do limite". A entrevistada sorri simpaticamente para a câmera e se despede "Obrigado!", mas a entrevistadora insiste: "Por que você acha grande demais?". A mulher se reaproxima e explica: "O uso de espaços públicos em Berlim, em geral, para monumentos ou memoriais.. Outros memoriais não são assim tão grandes. Deve-se mostrar respeito, com certeza, mas eu acho que isso passa do ponto". Chegando mais perto, ela abaixa o tom de voz para quase o volume de um sussurro: "Eu acho que, em geral, há uma tendência ao exagero". "O que é exagero?". "Tudo o que é esperado de nós, alemães! Isso já tem 50 anos, mas ainda estamos tendo nossos narizes esfregados nisso. Claro que os jovens devem conhecer a nossa história, mas às vezes isso é muito... Nossa geração tem sido sobrecarregada pela culpa. Eu acho que uma tensão muito grande é colocada sobre nós".

- "Está relacionado diretamente com a escala do que foi perpetrado. Da mesma forma, porém, uma pergunta: até que ponto a construcão do memorial pode ser considerada uma demonstração de megalomania?".

-“Típica exorbitância alemã !"
- "E os novos edifícios? Tudo bem? Eles não são muito grandes? Essa é a minha opinião. Tudo aqui é... Nós fizemos um tour ontem, e acho que foi dito umas dez ou vinte vezes, 'esta é a maior da Europa', 'este é o maior do mundo'. Eu acho que é uma coisa boa que o maior memorial esteja aqui para representar o que isso representa".

Outras, além de questionar a dimensão, explicitavam um incômodo com a localização e até mesmo com a arquitetura do Memorial:

- "Eu acho que um objeto como esse provoca uma reação que está mais para o antagônico do que para o incentivo de emoções que ele quer sugerir". "Por que? Você pode nos explicar?" "Porque é um espaço que é muito... no meio da vida da cidade, é muito cinza, muito morto... E eu acho que lembranca tem que vir do coração. Ela não deve ser forçada". "Você tem a impressão de que ela é forçada?". "Sim!".

- "É como se um espinho estivesse sendo pressionado em nossa própria carne, de modo a preservar o nosso sentimento de culpa. Eu não gosto disso".

- "Ele afronta você, e provavelmente foi feito para isso. Eu não tenho como lidar com esta arquitetura. As noções politicas por trás dele, sim, mas não com essa arquitetura".

Mas a dimensão, de acordo com o depoimento de Lea Rosh à mesma documentarista, foi intencionalmente determinada tendo em vista a representação do Holocausto:

- "Nós não dissemos como ele deveria parecer. Nós só dissemos, e eu ainda acredito nisso, que ele não poderia ser pequeno. Seis milhões de judeus homenageados com uma obscura e pequena pedra com a legenda "Em memória das vítimas do fascismo", não, obrigado!”15

156. EXPANSIVE Grounds. Direção: Gerburg Rohde-Dahl. [Frankfurt/Main]: Fischer Taschenbuch Verlag, 2002. 1 DVD (66 min.), color. Titulo original: Ein Weites Feld. Tradução noss 
A dimensão e a maneira nada sutil com que se insere no tecido da cidade centenária, ao mesmo tempo em que contribui para ideia de monumento tradicional, também traz uma reverberação do modernismo, herança trazida e exposta, entretanto, como observou Esther da Costa Meyer ${ }^{157}$, como uma terrivel ironia. Pela falta de um ponto central, de um foco de atenção através do qual uma narrativa poderia ser contada, pela dispersão a que induz os seus visitantes, convidando-os a mergulhar no seu mar de corredores e elementos indistinguíveis, a dimensão da obra carrega a experiência do espaço com uma forte ideia de seriação e de expansão indiscriminada e sem controle. Ao mesmo tempo, é bastante significativo que a inteligibilidade do espaço - a clareza e simplicidade das relações espaciais -, tão evidente na facilidade de navegação em um campo daquela dimensão, assim como a "inutilidade" 158 do conjunto e a indistinguibilidade dos elementos, sejam resultado da organização em uma rigorosíssima e arbitrária grid, da ideia de ordem regendo a configuração formal. Se, como em algumas leituras feitas sobre essa obra, nos referíssemos aos elementos trabalhados como uma alusão ou uma figuração, poderíamos dizer que a dimensão da obra é em alguma instância representação do modo de produção típico da era mecânica da Revolução Industrial. A possível analogia traz assim, mais um elemento para essa rede de relações construída na tentativa de representação da memória do Holocausto. Não apenas o massacre foi feito de maneira industrial - o aprisionamento de milhões de pessoas usadas como força de trabalho, ou simplesmente mantidas em condições precárias, a morte em massa nas câmaras de gás, a incineração ou o despejo em grandes covas coletivas -, mas também a perseguição executada desde a ascensão de Hitler ao poder, até os últimos anos do nazismo. 0 censo feito para identifica e classificar judeus e ciganos, assim como os graus de miscigenação, foi possivel, apesar da dimensão da tarefa, graças a uma conhecida tecnologia computacional americana que utilizava cartões perfurados. Transformados em dados muito bem catalogados, os indivíduos poderiam facilmente ser localizados e contabilizados. Um massacre da dimensão do Holocausto não foi possivel de ser feito através da expressão colérica, da explosão de ódio do antissemitismo, mas sim através da frieza e ordem dos sistemas computacionais. Em outro trecho de sua biografia, Albert Speer diz: "A ditadura de Hitler foi a primeira de um estado industrial nessa era de moderna tecnologia uma ditadura que empregou com perfeição os instrumentos tecnológicos para dominar seu próprio povo. Por meio de tais instrumentos tecnológicos como o rádio e os sistemas de endereços públicos, oitenta milhões de pessoas poderiam ser submetidas à vontade de um indivíduo. 0 telefone, o telégrafo e o rádio tornaram possivel transmitir o comando dos mais altos niveis diretamente aos mais baixos órgãos onde, devido à sua alta autoridade, eram executados acriticamente. Assim, muitos escritórios e esquadrões receberam de maneira direto esses comandos malignos. Os instrumentos tecnológicos tornaram possivel manter uma estreita vigilância sobre todos os cidadãos, assim como efetuar operações criminosas envoltas em um alto grau de sigilo. Para alguém de fora este aparelho estatal poderia se parecer com um emaranhado selvagem de cabos em uma central telefônica mas isso que parecia uma central poderia ser dirigido para uma única vontade. Ditaduras do passado precisavam de assistentes da mais alta qualidade nos mais baixos escalões de liderança também - homens que poderiam pensar e agir independentemente. $O$ sistema autoritário na era da tecnologia pode funcionar sem esses homens. Os meios de comunicação por si só lhe permitem mecanizar o trabalho da liderança menor. Assim, o tipo de receptor de ordens acritico é criado"159.

157. MEYER, Esther da Costa. "Speak, Memory". Art Forum, v.44, n.5, jan. 2006, p.48. 158. EISENMAN, Peter. "The futility of objects: Decomposition and the processes of differentiation" In: Eisenman inside out: selected writings, 1963-1988. New Haven, Yale University Press, 2004, p.187. Tradução nossa.

159. SPEER, Albert. Inside The Third Reich. New York, The Macmillan Company, 1970, p.520. Traduçãon nossa. 
ainda uma forte analogia na de morte como

o estado entrópico nas relações que formam a vida. Eisenman disse certa vez em uma palestra: "Eu queria que esse Memorial fosse um Mahnmal e não um Denkmal, um aviso mais do que uma lembrança. Ele deve permanecer como uma advertência contra a razão e a racionalidade que é a marca do século vinte, contra a eficiência das máquinas, da produção e do capital que podem levar ao erro. Este campo como o campo da razãa, ela se torna obsessiva, o caos se instala"160. Ao final desse longo dia, penso novamente na maneira como essa obra foi incorporada na vida da cidade e dos seus cidadãos. Após toda a polêmica que cercou o processo de projeto e construção, todo o incômodo que gerou pela sua localização, pela dimensão ou pela sua forma, inicialmente considerada pouco amigável, parece bastante significativo que a obra ainda seja motivo de outra interessante discussão sobre o uso: a parodica conversão da obra em um campo de brincadeiras e jogos de perseguição. 
86. Essas horas mais silenciosas do dia, quando todos já foram embora, têm algo de amedrontador. Vultos atravessando rapidamente de um lado para o outro o corredor e reaparecendo em outra transversal. São só dois moleques em uma perseguição silenciosa. Berlim é uma cidade segura.

87. Ruínas. Mesmo com todo o controle do processo industrial de fabricação das pedras, o tempo e a tendência à entropia se manifestam nas rachaduras que começaram a aparecer em algumas delas.

88. Fim da minha passagem por Berlim e pelo Memorial: os pássaros entoam todos ao mesmo tempo um canto que não executam a toda hora (um canto de final de dia), um ou outro grito agudo vindo de lá de dentro, o ruído constante da cidade e as vozes das pessoas que restaram. 0 céu vai do azul profundo acima da minha cabeça ao claro na minha testa, passando por uma estreita faixa de nuvens rosa e laranja até o branco amarelado no horizonte. A lua surge entre as poucas nuvens desse dia quente e, ao contrário do que eu esperaria, morre: desce lentamente até se esconder atrás das árvores do Tiergarten. Contrariando a vontade de Peter Eisenman, nessa hora as estelas parecem quentes. Seu cinza é contaminado pelas cores do céu e pela sensação do mormaço que começa a subir. Depois de um dia inteiro contendo-se, tendo que absorver na sua superfície escura toda a luz e todo o calor do sol sem esboçar a menor reação, frias, imóveis, rígidas, as estelas agora desabafam e liberam por suas faces um calor que se sente até mesmo sem tocá-las. 0 Memorial agora é um campo de cinzas quentes de um fogo a pouco extinto. 
Dar início é muito mais fácil e prazeroso do que concluir. Ao meno para mim. Isso se reflete não apenas na pequena dimensão desta considerações fınais, como na quantidade de caminhos que a partir daqui se abrem ou que permanecem abertos para trás. Um deles aponta para uma pesquisa mais aprofundada sobre o Memorial dos Judeus Assassinados da Europa, sobretudo considerando as fases de projeto e construção - objetivo que, a certa altura, esteve no horizonte da minha pesquisa -, que seria possível com o acesso ao acervo completo de Eisenman no Canadian Centre for Architecture 0 centro dispõe de uma ferramenta online de base de dados através da qual é possível acessar de maneira prévia boa parte do conteúdo do arquivo. Entretanto, a maior parcela do acervo de Peter Eisenman ainda encontra-se guardada em outro edifício, um arquivo off-site, esperando a catalogação detalhada e a digitalização. Lá estão dezoito discos, quinze modelos físicos e dois rolos de desenhos e anotações. De todo esse material, tive acesso apenas aos dois rolos e à foto de um dos modelos. Os discos, muito provavelmente, contêm os arquivos eletrônicos das diversas fases de projeto e construção e poderiam oferecer pistas para novas interpretações da obra, sobretudo no que se refere à configuração da ondulação do terreno e do campo de pedras e à aleatoriedade nas inclinações de cada elemento. 0 pape das ferramentas eletrônicas no processo de projeto foi ressaltado pelo próprio Eisenman em uma entrevista, mas, infelizmente não pôde ser verificado com mais segurança, seja pela falta de acesso aos arquivos, seja pela falta de tempo e de recursos financeiros para tenta uma nova consulta ao CCA e ao escritório do arquiteto. Da mesma maneira, o papel dos quinze modelos físicos, cuja documentação inexiste em periódicos e publicações do projeto. Segundo alegou o centro, os modelos estão em péssimas condições de preservação, o que motivou a negativa ao acesso.

Outro caminho também passaria pela consulta ao CCA: um estudo sobre os processos de projeto de Eisenman com o uso de diagramas gráficos e modelos ao longo da sua carreira. Obviamente, não sugiro como alternativa para uma pesquisa futura, mais uma panorâmica histórica do percurso do arquiteto, e sim um aprofundamento (e talvez revisão) de algumas interpretações consolidadas a respeito sobretudo, da primeira fase da sua carreira (interpretações que, inclusive, tem lugar no meu trabalho). Ao encontrar pela primeira vez alguns desenhos feitos à mão, muito diferentes enquanto raciocínio gráfico das perspectivas axonométricas largamente conhecidas e publicadas, fui tomado por uma série de dúvidas com relação a interpretações que eu havia feito e que, pelo pouco tempo que me restava, já não poderia mais rever.

90. 0 que sobrou de toda essa experiência? Sentado aqui em frente ao computador, minha relação com tudo aquilo que fez parte da pesquisa (as obras e textos de Eisenman, as ruas e construções de Berlim, os monólitos e o enorme campo ondulado do Memorial), é praticamente a mesma que tenho com o que a acompanhou (os cômodos do pequeno apartamento alugado, o suco de maçã em garrafa, o sobrevoo e aterrissagem na cidade, as idas à biblioteca da FAU, a cobertura em ruínas por trás do tecido azul): uma relação de memória. Tentando construir este texto, me deparei a todo tempo com elementos perdidos no meio do caminho, recuperados através de associações com aquilo que eu escrevia ou desenhava. De uma frase emergiam outros textos, obras, filmes, imagens, cujas relações que construíam iam aos poucos dando forma à dissertação. Algumas delas surgiam como uma lembrança obscura de algo acontecido há muito tempo, como quando nos deparamos com a similaridade com algo que já vivemos ou vimos. Ou como quando confundimos a imagem congelada em uma fotografia antiga de família com uma lembrança pessoal. Assim eram, e ainda são os inúmeros textos que li durante o mestrado, as imagens vistas em revistas, livros e sites - algumas encontradas por um acidente causado pelos mecanismos 
eletrônicos de busca - as ideias construídas na análise de um desenho técnico ou na contemplação de um terreno baldio, muita delas (a maioria, certamente) perdidas para sempre na fusão da subconsciência. Foi somente depois de acabar este texto que percebi a sua utilidade (que tanto questionei durante o processo), ou seja, a de dar e ser a forma acabada da memória do processo de pesquisa do mestrado. Se antes a dissertação, possuía para mim muito menos importância do que a pesquisa (e, de certa forma, configurava uma espécie de traição de todo o raciocínio), agora "produto final" e "processo" se reconciliam. Assim, respondendo, o que sobrou de toda essa experiência: a dissertação.

REFERÊNCIAS BIBUIOGRÁFICAS

E LISTA DE IMAGENS 
REFERÊNCIAS

“La Pagina a Berlino in Lindenstrasse, Kreuzberg”. Domus, n. 808, out. 1998, pp.103-104.

AGAMBEN, Giorgio. Die zwei Gedächtnisse. Die Zeit, Hamburg, n.19, 04 ago, 2005.

AGAMBEN, Giorgio. O que resta de Auschwitz. São Paulo, Boitempo, 2008

AHR, Johan. "Memory and mourning in Berlin: on Peter Eisenman's Holocaust-Mahnmal". Modern Judaism, vol. 28, n. 3, out. 2008. pp. 283-305.

ANDRADE, Manuella Marianna. "Entre a crítica e a admiração: considerações sobre o discurso poético de Peter Eisenman". Arquitextos, abr. 2011.

ARANTES, Otília Beatriz Fiori. O Lugar da Arquitetura depois dos Modernos. São Paulo, Edusp, 2000.

ARCHITETTURA. "Il cammino della memoria". Architettura, vol. 42, n. 491, 1995. pp. 506-510.

ARQUINE. "Monumento a los judíos asesinados en Europa". Arquine revista internacional de arquitectura y diseño, n. 31 primavera de 2005. pp. 26-31.

ARTIGAS, João Batista Vilanova. Caminhos da arquitetura. São Paulo, Cosac Naify, 2004

BARRIS, Roann. "Architectures of Memory and Counter-Memory: Berlin and Bucharest". The annual Ralph and Ruth Fisher Forum: Interpreting Emotion in Eastern Europe, Russia and Eurasia, University of Illinois, 19-21 de junho de 2008

BELPULITI, Marco. "Labirinto di cemento". Domus, n. 881, mai. 2005. pp. 72-79.
BENJAMIN, Andrew E “Now still absent: Eisenman's Memorial to the Murdered Jews of Europe". Architectural theory review: journal of the Department of Architecture, the University of Sydney, vol. 8, n. 1, abr. 2003. pp. 57-62.

BINET, Hélène; RAUTERBERG, Hanno; WASSMANN, Lukas. Holocaust Memorial Berlin. Baden, Lars Müller Publishers, 2005.

BONDER, Nilton. Portais secretos: acessos arcaicos à internet. Rio de Janeiro, Rocco, 1996.

BONVECCHI, Liliana. "Materia infranqueable: Memorial a los judíos europeos asesinados [Berlin]”. Summa+, n. 81, ago. 2006 pp. 88-93.

CANETTI, Elias; JABÈS, Edmond. "Peter Eisenman: Memoriale per gli Ebrei assassinati d'Europa a Berlino”. Casabella, vol. 69, n. 735, jul.-ago. 2005. pp. 4-21.

CHCHEGLÓV, I. K. "Algumas características da estrutura de As Metamorfoses de Ovídio”. In: SCHNAIDERMAN, B. Semiótica Russa. São Paulo, Perspectiva, 1979.

CLELLAND, Doug. "Architectural Design Profile - Berlin: an architectural history". Architectural Design, n. 53, 1983. pp. 11-12.

COOK, Peter. "Berlin may be entering a new era where free spirits reign again”. Architectural review, vol. 221, n. 1323 , mai. 2007. p. 34.

COX, Ian; Evans, Barrie. "CQ: concrete quarterly". Architects journal, vol. 221, n. 21, 2 de junho de 2005. pp. 1-16; p. 54; p. 71

COYNE, Richard. Derrida for Architects. New York, Routledge, 2011.

CRIMP, Douglas. "Richard Serra: Sculpture Exceeded". October, vol. 18, 1981.

RIMP, Douglas. "The End of Art and the Origin of the Museum" Art Journal, vol. 46, n. 4, 1987. 
DAL CO, Francesco; EISENMANN, Peter. "Peter Eisenman: dalla Casa del Fascio al Monumento all'Olocausto: una conversazione intorno al significato e ai fini della pratica dell-architettura (e qualche ricordo)”. Casabella, vol. 64, n. 675 , fev. 2000. pp. 32-37.

DAL CO, Francesco. "Existing in the absence of names". Log, n. 6 , outono de 2005, pp. 91-95.

DAVEY, Peter. "Field of memory: the new memorial to european jews who perished under the nazis is an unnerving presence in the heart of Berlin". Architectural review, vol. 218, n. 1301, jul. 2005. pp. 80-83.

DAVIDSON, Cynthia (org.). Tracing Eisenman. New York, Rizzoli, 2006. DELEUZE, Gilles. A dobra: Leibniz e o Barroco. Campinas, Papirus, 1991.

DERRIDA, Jacques. "A letter to Peter Eisenman". Assemblage, n. 12, ago. 1990.

DERRIDA, Jacques. "Entrevista de Jacques Derrida a Eva Meyer: Uma arquitetura onde o desejo pode morar". In: NESBITT, Kate. Uma nova agenda para a arquitetura: antologia teórica (1962-1995). São Paulo, Cosac Naify, 2006, p.166. DÖBLIN, Alfred. Berlin Alexanderplatz. São Paulo, Martins Fontes, 2009

DUMAS, Sophie. "Métaphore du vivant: Projet sélectionné/ Peter Eisenman et Felice Fanuele". L'architecture d'aujourd'hui, n. 326, fev. 2000. pp. 58-59.

EISENMAN, Peter; DERRIDA, Jacques. “Talking about Writing”. Any 1, n. 0, mai.-jun. 1993. pp. 18-21.

EISENMAN, Peter; ENDERS, Kilian. "Enormity of the banal: Eisenman's memorial of order and chaos". Architecture today, n. 161, set. 2005. pp. 78-80; pp. 83-84.

EISENMAN, Peter; GRAVES, Michael. "A Conversation with Peter Eisenman and Michael Graves". Dimensions: Journal of the University of Illinois, n. 4, 1990. pp. 10-13.

EISENMAN, Peter; KOOLHAAS, Rem; KIPNIS, Jeffrey; SOMOL, Robert Super-critical - Peter Eisenman \& Rem Koolhaas with Jeffre Kipnis \&t Robert Somol. London, AA Publications, 2010.
EISENMAN, Peter; KRIER, Leon "Peter Eisenman versus Leon Krier: 'My Ideology is Better Than Yours"'. Architectural Design, vol. 59, n. 9-10, set.-out. 1989. pp. 6-18.

EISENMAN, Peter; MASSAD, Fredy; GUERRERO YESTE, Alicia. "Peter Eisenman" [entrevista]. Vitruvius, jul. 2005.

EISENMAN, Peter; ROBERTSON, Jaquelin. "Kock-/ Friedrichstrasse, Block 5". Architectural Design, vol. 53, n. 1-2, 1983. pp. 91-93.

EISENMAN, Peter; SALANT, katherine. Peter Eisenman on the difference between house and home. The Washington Post, Washington, 29 abr. 2011.

EISENMAN, Peter; SPIEGEL. "How Long Does One Feel Guilty?" Disponivel em: <www.spiegel.de/international/spiegel -interview-with-holocaust-monument-architect-peter -eisenman-how-long-does-one-feel-guilty-a-355252. html >. Acesso em: 05 jan. 2014.

EISENMAN, Peter. "Aspects of Modernism: The Maison Dom-ino and the Self-Referential Sign". Oppositions, n. 15-16, 1979. pp. 118-128.

EISENMAN, Peter. "Cardboard Architecture". $A+U$, n. 35, nov. 1973. pp. 185-189.

EISENMAN, Peter. "Conceptual Architecture II: Double Deep Structure I". $A+U$, n. 39, mar. 1974. pp. 83-88.

EISENMAN, Peter. "Dall'oggetto alla relazionalità: la Casa del Fascio di Terragni”. Casabella, n. 344, jan. 1970. pp. 38-41.

EISENMAN, Peter. "Diagram: an original scene of writing". Any, n. 23, 1998. pp. 27-29.

EISENMAN, Peter. "Eisenman Architects". $A+U$, n. 220, jan. 1989 pp. 9-52.

EISENMAN, Peter. "From Object to Relationship II: Casa Giuliani Frigerio. Giuseppe Terragni.” Perspecta, n. 13-14, 1971. pp. 36-75.

EISENMAN, Peter. "House El Even Odd". $A+U$, n. 123, dez. 1980 pp. 96-98.

EISENMAN, Peter. "House III: To Adolph Loos and Bertolt Brecht". Progressive Architecture, n. 55, mai. 1974. p. 92. 
EISENMAN, Peter. Houses for Sale. New York, Leo Castelli GalleryRizzoli International Publications, 1980.

EISENMAN, Peter. "Housing on Kockstrasse, Southern Friedrichstadt, Berlin, 1982-1986". GA Houses, n. 23, ago. 1988, pp. 158-159.

EISENMAN, Peter. "Interview: Leon Krier and Peter Eisenman". Skyline, fev. 1983. pp. 11-15.

EISENMAN, Peter. "Interview: Richard Serra and Peter Eisenman". Skyline, abr. 1983. pp. 14-18

EISENMAN, Peter. "Le rappresentazioni del dubbio: nel segno del segno". Rassegna, n. 9, mar. 1982. pp. 69-74.

EISENMAN, Peter. “M Emory Games”. In: M Emory Games: Emory Center for the Arts. New York, Rizzoli, 1995.

EISENMAN, Peter. "Notes on Conceptual Architecture II A". On Site, n. 4, 1973. pp. 41-44.

EISENMAN, Peter. "Post-Functionalism”. Oppositions, n. 6, 1976. EISENMAN, Peter. Chora L Works. New York, Monacelli Press, 1997. EISENMAN, Peter. "The City of Artificial Excavation”. Architectura Design, vol. 53, n. 1-2, jan. 1983. pp. 91-93.

EISENMAN, Peter. "Wexner Center for the Visual Arts, Ohio". Architectural Design, vol. 58, n. 3-4, mar.-abr. 1988 pp. 62-63.

EISENMAN, Peter. "Biology Center for the J. W. Goethe University of Frankfurt, Frankfurt am Main, 1987". Assemblage, n.5, fev. 1988, p.30. Tradução nossa.

EISENMAN, Peter. "Laboratorios in Frankfurt”. Arquitectura, n. 270, jan.-fev. 1988. pp. 80-91.

EISENMAN, Peter. "Memorial to the murdered Jews of Europe". The Leo Baeck Memorial Lecture, n. 49, 2005.

EISENMAN, Peter. "Monumento all'Olocausto: Berlino 1998" Casabella, vol. 64, n. 675, fev. 2000. pp. 38-41.

EISENMAN, Peter. "Notes on Conceptual Architecture II A". In: EDRA 4: Fourth International EDRA Conference. 1973, p.322.

EISENMAN, Peter. "Notes on Conceptual Architecture: towards a definition”. Design Quaterly, n.78/ 79, 1970, p.1-5.
EISENMAN, Peter "Peter Eisenman: Memorial to the Murdered Jews of Europe, Berlin, Germany 1998-2005”. $A+U$, n 419, ago. 2005. pp. 36-53.

EISENMAN, Peter. "Towards an Understanding of Form in Architecture". Architectural Design, n. 33, out. 1963. pp. 457-458.

EISENMAN, Peter. "Visões que se desdobram: a arquitetura na era da mídia eletrônica". In: NESBITT, Kate. Uma nova agenda para a arquitetura: antologia teórica (1962-1995). São Paulo, Cosac Naify, 2006. p.601.

EISENMAN, Peter. Diagram Diaries. London, Thames \& Hudson, 1999.

EISENMAN, Peter. Eisenman inside out: selected writings, 1963 1988. New Haven, Yale University Press, 2004.

EISENMAN, Peter. House X. New York, Rizzoli, 1982.

EISENMAN, Peter. Il giardino dei passi perduti: uma installazione al Museo di Castelvecchio. Verona, Marsilio, 2004.

EISENMAN, Peter. The formal basis of modern architecture. Baden, L. Müller, 2006.

ENDLICH, Stefanie; BUTTLAR, Florian von. "Costruire? Aspettare? Rinunciare?”. Domus, n. 808, out. 1998, pp.97-102.

FERNÁNDEZ-GALIANO, Luis. "2005 en doce edificios". AV monografías, n.117-118, jan.-abr. 2006. pp. 286-293.

FERNÁNDEZ-GALIANO, Luis. "Laberintos del orden: el Memoria del Holocausto en Berlín”. Arquitectura Viva, n. 62, set -out. 1998. p. 76-77.

FERNÁNDEZ-GALIANO, Luis. "Mayo: la memoria y sus laberintos". AV monografías, n. 117-118, jan.-abr. 2006. pp. 242-245.

FERREIRA, Aurélio B. de Hollanda. Novo Dicionário da Língua Portuguesa. 2.ed. Rio de Janeiro, Nova Fronteira, 1986.

FOSTER, Hal; HUGHES, Gordon. October Files: Richard Serra. Cambridge, The MIT Press, 2000.

FRAHM, Klaus. Memorial to the Murdered Jews of Europe. Berlin Nicolai Verlag, 2005. 
FRAJNDLICH, Rafael. “Um debate americano: mediação, escultura e arquitetura: sobre a entrevista de Peter Eisenman a Richard Serra em 1983”. ARS (São Paulo), vol. 7, 2009. pp. 50-63.

FRAMPTON, Kenneth. História crítica da arquitetura moderna. São Paulo, Martins Fontes, 2003.

GAUDING, Daniela. "Die Synagoge Lindenstraße”. Jüdisch Miniaturen, n. 135. Berlim, HentrichEtHentrich, 2013.

GEISEL, Eike. Berlim, 1919-1933: a encarnação extrema da modernidade. Rio de Janeiro, Jorge Zahar, 1993.

GIOVANNINI, J. "Pitching curves". Art news, vol. 99, n. 10, nov. 2000. pp. 136-140.

GRAHAM, Dan. "Arte em relação à arquitetura", In: Escritos de artistas: anos 60-70. Rio de Janeiro, Zahar, 2009, p.429-451.

GREGOTTI, Vittorio. "Commenti all'intervista di Peter Eisenman" Domus, n. 827, jun. 2000. pp. 46-47.

HATTON, Brian. "Judenplatz Vienna 1996". AA files, n. 33, 1997. pp. 88-93.

HEATHCOTE, Edwin. Monument Builders: Modern Architecture and Death. London, Academy Editions, 1999.

HEIMROD, Ute; SCHLUSCHE, Günter; SEFERENS, Horst. Der Denkmalstreit - das Denkmal? Die debatte um das "Denkmal für die ermordeten Juden Europas": Eine Dokumentation. Berlin, Philo Verlag, 1999.

HESSEL, Franz. Promenades dans Berlin. Paris, L'herne, 2012.

HOBSBAWN, Eric J. Tempos interessante: uma vida no século $X X$. São Paulo, Companhia das Letras, 2002.

INGERSOLL, Richard. "Campo de estelas: Memorial del Holocausto, Peter Eisenman en Berlín”. Arquitectura Viva, n. 103 2005. pp. 90-91.

KOPPENFELS, Johanna von. Jewish Cemeteries in Berlin. Berlin, Berlin Edition, 2000
HUYSSEN, Andreas. "The Vamp and the Machine: Technology and Sexuality in Fritz Lang's Metropolis". New German Critique, n.24-25, pp.221-237.

KRAUSS, Rosalind. "Death of a Hermeneutic Phantom: Materialization of the Sign in the Work of Peter Eisenman". $A+U$, jan. 1980. pp. 189-219.

LE CORBUSIER. Por uma arquitetura. São Paulo, Perspectiva, 1977, p.27. LEVI, Primo. É isto um homem?. Rio de Janeiro, Rocco, 1988, p.131

LOOS, Adolf. Ornement et crime. Paris, Payot \&t Rivages, 2003.

LOTMAN, I. M. A estrutura do texto artístico. Lisboa, Editorial Estampa, 1978.

LUCENA, Francisco Palmeira de. "Arquivo, Arte e Arquitetura: Memorial aos Judeus Assassinados da Europa”. IV Encontro de História da Arte da UNICAMP. Campinas, 2008.

LUCENA, Francisco Palmeira de. Peter Eisenman: autonomia critica da arquitetura. Rio de Janeiro, PUC-RJ, 2010. Dissertação de Mestrado.

MACHADO, Irene; ROMANINI, Anderson V. "Semiótica da comunicação: da semiose da natureza à cultura”. Revista FAMECOS, v. 17, n.2, p. 89-97, 2010, Porto Alegre.

MACHADO, Irene. "Diagrama como problema semiótico". In: Diagramas: explorações no pensamento-signo dos espaços culturais. São Paulo, Alameda, 2014, no prelo.

MASP. Malhas, escalas, rastros a dobras na obra de Peter Eisenman. São Paulo, MASP, 1993.

MEYER, Esther da Costa. "Speak, Memory". Art forum, vol. 44, n. 5, jan. 2006. pp. 47-48.

MIRANDA, Juliana Torres de. Conceito e projeto: o papel da teoria na produção arquitetônica de Eisenman, Hejduk, Libeskind Tschumi. São Paulo, Fauusp, 2007. Tese de doutorado

MOMA. Five architects: Eisenman, Graves, Gwathmey, Hejduk, Meier. New York, Oxford University Press, 1975. 
MONEO, Rafael. Inquietação teórica e estratégia projetual na obra de oito arquitetos contemporâneos. São Paulo, Cosac Naify, 2008, p.139.

MONTANER, Josep Maria. Después del Movimento Moderno: Arquitectura de la segunda mitad del siglo XX. Barcelona, Gustavo Gili, 1993.

MORNEMENT, Adam. "Never ending story". World architecture, n. 77, jun. 1999. pp. 26-27.

NACHAMA, Andreas; SCHOEPS, Julius H., SIMON, Hermann. Jews in Berlin. Leipzig, Seemann Henschel, 2003.

PAGE, Max. "Memory field". Architecture, vol. 94, n. 6, jun. 2005. pp. 38-45.

PASSARO, Andrés Martín. 0 projeto arquitetônico e a análise projetual como metodologia de trabalho. São Paulo, Fauusp, 1996. Dissertação de mestrado.

PATTERSON, R. "Introduction to the holocaust section (special section: the tragic in architecture)". Architectural Design, vol. 70, n. 5, out. 2000. pp. 52-53.

PIGNATARI, Décio. Semiótica da arte e da arquitetura. São Paulo, Cultrix, 1981, p.111.

PORTO FILHO, Gentil Alfredo Magalhães Duque. O fim do objeto: linguagem e experimentação na arquitetura depois do Modernismo. São Paulo, Fauusp, 2004. Tese de Doutorado.

RAMOS, Fernando Vázquez. "19211/2: Van Doesburg e (é) o vento que varre a Bauhaus de Weimar nos anos 20", In: VII Fórum de Arte de Brasília. Brasília, 2009.

RAUTERBERG, Hanno. Entrevistas com arquitetos. Rio de Janeiro, Viana \& Mosley, 2009.

RICHARD, Lionel. Berlim, 1919-1933: a encarnação extrema da modernidade. Rio de Janeiro, Jorge Zahar, 1993.

RIZZI, Renato. La muraglia ebraica: l'imperio eisenmaniano. Milano, Mimesis, 2009.

ROWE, Colin; KOETTER, Fred. Collage City. Massachusetts, The MIT Press, 1983
ROWE Colin “The Mathematics of the Ideal Villa”. In: Architectural Review, mar. 1947, pp.101-4.

RUYTER, Thibaut de. "Peter Eisenman's Memorial to the Murdered Jews of Europe". Art Press, n. 317, nov 2005, p.41.

SAEHRENDT, Christian. "Holocaust Memorial, Berlin". Burlington magazine, vol. 147, n. 1233, dez. 2005. pp. 844-845.

SCHLÖR, Joachim. Memorial to the Murdered Jews in Europe. München, Prestel, 2008.

SCHMEING, Astrid. "Eisenman's design for the Berlin Holocaust Memorial - a modern statement?". Architectural design vol. 70, n. 5, out. 2000. pp. 60-65.

SERRA, Richard. Writings/ Interviews. Chicago, University of Chicago Press, 1994.

SOUZA, Douglas Lopes de. A configuração do discurso do diagrama na arquitetura contemporânea. São Paulo, Fauusp, 2010 Dissertação de mestrado.

SPEER, Albert. Inside The Third Reich. New York, The Macmillan Company, 1970.

SPERLING , David Moreno. Arquiteturas continuas e topologiasimilaridades em processo. São Carlos, Eescusp, 2003. Dissertação de mestrado.

SPERLING, D. M. "Diagrama e processo. Diagrama como processo". In: VII Congresso da Sociedade Iberoamericana de Gráfica Digital (SIGraDi) Cultura Digital e Diferenciacion, 2003.

SPERLING, David Moreno. Espaço e Evento: considerações criticas sobre a arquitetura contemporânea. São Paulo, Fauusp, 2008. Tese de doutorado.

STEPHENS, Suzanne. "Peter Eisenman's vision for Berlin's Memoria to the Murdered Jews of Europe". Architectural record, vol. 193, n. 7, jul. 2005. pp. 120-127.

STEVENS, Quentin. "Nothing more than feelings: abstract memorials". Architectural theory review: journal of the Department of Architecture, the University of Sydney, vol. 14, n. 2, ago. 2009. pp. 156-172. 
STEVENS, Quentin. "Why Berlin's Holocaust Memorial is such a popular playground." OASE: Journal for Architecture n. 77, dez. 2008. pp. 71-79.

STIFTUNG DENKMAL FÜR DIE ERMORDETEN JUDEN EUROPAS. Information on the Foundation Memorial to the Murdered Jews of Europe. Berlin, 2012.

STIFTUNG DENKMAL FÜR DIE ERMORDETEN JUDEN EUROPAS Materials on the Memorial to the Murdered Jews of Europe. Berlin, Nicolai Verlag, 2005.

STIFTUNG DENKMAL FÜR DIE ERMORDETEN JUDEN EUROPAS. Memorial to the Murdered Jews of Europe: Guide to the Information Centre. Berlin, Deutscher Kunstverlag Berlin München, 2010.

STIFTUNG DENKMAL FÜR DIE ERMORDETEN JUDEN EUROPAS. Opening Memorial to the Murdered Jews of Europe - 10 May 2005: Speeches and Pictures. Berlin, 2005.

STIFTUNG DENKMAL FÜR DIE ERMORDETEN JUDEN EUROPAS. Tätigkeitsbericht der Stiftung Denkmal für die ermordeten Juden Europas, 2000 bis 2002. Berlin, 2002.

STIFTUNG DENKMAL FÜR DIE ERMORDETEN JUDEN EUROPAS. Tätigkeitsbericht der Stiftung Denkmal für die ermordeten Juden Europas, 2003 bis 2005. Berlin, 2002.

STIFTUNG DENKMAL FÜR DIE ERMORDETEN JUDEN EUROPAS. Tätigkeitsbericht der Stiftung Denkmal für die ermordeten Juden Europas, 2006 bis 2008. Berlin, 2002.

STIFTUNG DENKMAL FÜR DIE ERMORDETEN JUDEN EUROPAS. Tätigkeitsbericht der Stiftung Denkmal für die ermordeten Juden Europas, 2009 bis 2011. Berlin, 2002.

STIFTUNG TOPOGRAPHIE DE TERRORS. Topography of Terror: Gestapo, SS and Reich Security Main Office on Wilhelm and Prinz Albrecht Strasse: a documentation. Berlin, 2010.

STREITSCHRIFT, Eine. Der wettbewerb für das "Denkmal für die ermordeten Juden Europas”. Berlin, Verlag der Kunst, 1995.
THOMAS, G. "A wound still festering at the heart of Germany". Art Newspaper, vol. 10, n. 95, set. 1999.

TOPOS. "Memorial to the Murdered Jews of Europe, Berlin [Peter Eisenmann, architect]". Topos: the international review of landscape architecture and urban design, n. 56, 2006. pp. 118-119.

TSCHUMI, Bernard; WALKER, Enrique. Tschumi on Architecture: Conversations with Enrique Walker. New York, The Monacelli Press, 2006.

URBANI, Monica. Instabile e atopico: l'architettura di Peter Eisenman e il decostruzionismo di Jacques Derrida. Rimini, Guaraldi, 2009.

VALÉRY, Paul. Introdução ao método de Leonardo da Vinci. São Paulo, Editora 34, 1998.

VENTURI, Robert; BROWN, Denise Scott. "Uma significação para os estacionamentos dos supermercados A\&tP, ou Aprendendo com Las Vegas". In: NESBITT, Kate. Uma nova agenda para a arquitetura: antologia teórica (19621995). São Paulo, Cosac Naify, 2006, p.346.

VIDLER, Anthony. The architectural uncanny: essays in the modern unhomely. Cambridge, The MIT Press, 1992.

WISE, Michael Z. "Berlin's Holocaust Memorial: On a vast site in the center of Berlin, Peter Eisenman's stark, haunting Holocaust memorial offers a glimpse into the heart of darkness". Disponivel em: <www.travelandleisure.com/ articles/concrete-memory>. Acesso em: 05 jan. 2014.

WISNIK, Guilherme. Dentro do nevoeiro: diálogos cruzados entre arte e arquitetura contemporânea. São Paulo, FAUUSP, 2012. Tese de doutorado.

WITTKOWER, Rudolf. Architectural Principles in the Age of Humanism. The Warburg Institute, London, 1949.

YAMAMOTO, João Carlos Amaral. "Espaço e diagrama”. Arq.Urb, n.7, 2012, p. 17-32 
YAMAMOTO, João Carlos Amaral. "Na trilha dos textos de Eisenman". In: Diagramas: explorações no pensamento-signo do espaços culturais. São Paulo, Alameda, 2014, no prelo.

YAMAMOTO, João Carlos Amaral. "Sobre o Memorial dos Judeus Assassinados da Europa”. In: Anais do 20 Seminário Internacional Representar Brasil 2013: As representações na Arquitetura, Urbanismo e Design, 2013. p. 770-785

YOUNG, James E. At Memory's Edge: After-Images of the Holocaust in Contemporary Art and Architecture. New Haven, Yale University Press, 2000

YOUNG, James E. The Texture of memory: Holocaust Memorials and Meaning. New Haven, Yale University Press, 1993.

ZACH, Andrea. "Memorial to the Murdered Jews of Europe in Berlin The 'Spectacular [A]ffect' of Vergangenheitsbewältigung”. International Journal of Zizek Studies, vol. 6, n. 2, 2012.

SITES

YAD VASHEM. Instituto internacional de pesquisa do holocausto. Disponivel em: www.db.yadvashem.org

STATISTIK DES HOLOCAUST. Estatísticas sobre a deportação da população judaica durante o nazismo. Disponível em: www.statistik-des-holocaust.de

JÜDISCHES MUSEUM BERLIN. Disponível em: www.jmberlin.de

STOLPERSTEINE. Projeto de arte para a Europa por Gunter Demnig. Disponivel em: www.stolpersteine.eu

GEDENKTAFELN IN BERLIN. Informações sobre placas comemorativas em locais históricos em Berlim. Disponível em: $<$ www.gedenktafeln-in-berlin.de $>$.

STOLPERSTEINE IN BERLIN. Disponível em: <www.stolpersteine -berlin.de/en/biografie/763>.

MUSEUM BLINDENWERKSTATT OTTO WEIDT. Disponivel em: $<$ www.museum-blindenwerkstatt.de/en/ausstellung themen/the-situation-in-the-workshop-for-the-blind>

UNITED STATES HOLOCAUST MEMORIAL MUSEUM. Disponive em: <www.ushmm.org/online/hsv/source_view. php? SourceId=7107>.

STOLPERSTEINE INITIATIVE FÜR MÜNCHEN. Disponível em: $<$ www.stolpersteine-muenchen.de/english.php $>$.

YOUNG, James E. Germany's vanishing Holocaust monuments. Disponivel em: <www.gerz.fr/deb/put_file. html?ident=d0cb109e93e99da34f3f6fb7ae44de24>.

STOLPERSTEINE. Projeto de arte para a Europa por Gunter Demnig. Disponível em: <www.stolpersteine.eu $>$.

TAZ. Versão eletrônica do jornal diário. "Wer gedenkt am besten?" Disponível em: <www.taz.de/!19361>.

\section{FILMES}

ALEMANHA, ano zero. Direcão: Roberto Rossellini. Itália : Teverfilm [produção]: Union Générale Cinématografique [produção] : Sadfi [produção], 1930 São Paulo: Versátil Home Vídeo [distribuição], 2007. 1 DVD (72 min.), p\&tb. Título original: Germania anno zero.

ARQUITETURA da destruição. Direção: Peter Cohen. Narração: Bruno Ganz. Suécia: Svenska Filminstitute [produção] Poj Filmproduktion AB [produção]: Film \&t Teater [produção], 1989 [produção] São Paulo: Versátil Home Video, 2006. 1 DVD (121 min.), color, p\&tb. Título original: Undergangens Arkitektur. Tradução nossa.

ASAS do desejo. Direção: Wim Wenders. Alemanha : Road Movies Filmproduktion [produção] : Westdeutscher Rundfunk [produção] : Argos Films [produção], 1987 São Paulo : Vídeo Arte [distribuição], 198-. 1 videocassete (128 min.), color, p\&tb. Título original: Der Himmel über Berlin. 
BERLIM, sinfonia da metrópole. Direção: Walther Ruttmann. Alemanha: Fox-Europa Film [produção], 1927 s.l.: Continental Home Vídeo [distribuição], 200-. 1 DVD (77 min.), p\&tb. Título original: Berlin, Die Sinfonie der Großstadt.

EIN WEITES Feld. Direção: Gerburg Rohde-Dahl. [S.l.]: Rohde-Dahl, 2008. 1 DVD (66 min).

EXPANSIVE Grounds. Direção: Gerburg Rohde-Dahl. [Frankfurt/ Main]: Fischer Taschenbuch Verlag, 2002. 1 DVD (66 min.), color. Título original: Ein Weites Feld.

METRÓPOLIS. Direção: Fritz Lang. Alemanha : Universum Film Aktiengesell [produção], 1926 São Paulo : Continental Home Vídeo [distribuição], 2004. 1 DVD (124 min), p\&tb. Título original: Metropolis.

O TRIUNFO da vontade. Direção: Leni Riefenstahl. Alemanha : Leni Riefenstahl-Produktion [produção] : NSDAP Reichsleitung [produção], 1934 Bloomington : Synapse Films [distribuicão], c2001. 1 DVD (120 min.), petb. Título original: Triumph des Willens.

OS AMANTES da Pont-Neuf. Direção: Leos Carax. Fotografia: JeanYves Escoffier. Música: Arvo Pärt, Frédéric Chichin David Bowie. [Paris] : Films Christian Fechner FILMSA2, 1991. 1 DVD (125 min.), color. Título original: Les amants du Pont-Neuf.

OS INCOMPREENDIDOS. Direção: François Truffaut. Fotografia Henri Decaë. Roteiro: Marcel Moussy, François Truffaut. [Paris] : Les Films du Carrosse, 1959 Manaus, AM : Microservice, 2003. 1 DVD (100 min.), petb. Título original: Les quatre cents coups.

PETER Eisenman: Building Germany's Holocaust Memorial. Direção: Michael Blackwood. [S.1.]: Michael Blackwood Productions, 2006. 1 DVD (58 min).

STOLPERSTEIN. Direção: Dörte Franke. Alemanha : Film Kino Text, 2008. 1 DVD (73 min), color.

\section{AUDIO}

EISENMAN, Peter. "Corner in Richard Serra: the architectural implications of his recent works". In: New York - The Creative Catalyst [conferência realizada no MoMA em 12 de julho de 2007]. Audio. Disponível em: <www. moma.org/explore/multimedia/audios/82>

SERRA, Richard. "Art talk: Richard Serra with Edward Goldman" [entrevista]. Audio. Disponível em: <www.kcrw.com/ etc/programs/at/at980922richard_serra $>$

\section{ISTA DE IMAGENS}

\section{CAPITULO 01}

01. Antonio Dias, The Tripper, 1970

2. www.verlustdernacht.de

03. EISENMAN, Peter. The formal basis of modern architecture. Baden, L. Müller

04. EISENMAN, Peter. The formal basis of modern architecture. Baden, L. Müller

05. EISENMAN, Peter. "Notes on Conceptual Architecture: towards a definition”. Design Quaterly, n.78/ 79, 1970, p.1-5.

06. ROBERT SMITHSON, Asphalt rundown, Roma,1969.

07. SOL LEWITT, Incomplete Open Cube No.5-6, 1974.

08. EISENMAN, Peter. House X. New York, Rizzoli, 1982. 
09. BOESIGER, W.; GIRSBERGER, H. Le Corbusier: 1910-56. Barcelona, Gustavo Gili, 1971.

10. MOMA. Five architects: Eisenman, Graves, Gwathmey, Hejduk, Meier. New York, Oxford University Press, 1975.

11. SOL LEWITT, Variations of Incomplete Open Cubes, 1974

12. STRAATEN, Evert van. Theo van Doesburg: Peintre et architecte. Paris: Gallimard / Electa, 1993.

13. MOMA. Five architects: Eisenman, Graves, Gwathmey, Hejduk, Meier. New York, Oxford University Press, 1975.

14. DAVIDSON, Cynthia (org). Tracing Eisenman. New York, Rizzoli, 2006.

15. Canadian Center for Architecture

16. EISENMAN, Peter. House X. New York, Rizzoli, 1982.

17. EISENMAN, Peter. House X. New York, Rizzoli, 1982.

18. EISENMAN, Peter. House X. New York, Rizzoli, 1982.

19. EISENMAN, Peter. Diagram Diaries. London, Thames \&t Hudson, 1999.

20. BOESIGER, W.; GIRSBERGER, H. Le Corbusier: 1910-56. Barcelona, Gustavo Gili, 1971.

21. DAVIDSON, Cynthia (org). Tracing Eisenman. New York, Rizzoli, 2006.

22. DAVIDSON, Cynthia (org). Tracing Eisenman. New York, Rizzoli, 2006.

23. DAVIDSON, Cynthia (org). Tracing Eisenman. New York, Rizzoli, 2006

24. DAVIDSON, Cynthia (org). Tracing Eisenman. New York, Rizzoli, 2006.

25. DAVIDSON, Cynthia (org). Tracing Eisenman. New York, Rizzoli, 2006.

26. DAVIDSON, Cynthia (org). Tracing Eisenman. New York, Rizzoli, 2006.

27. Canadian Center for Architecture

28. Canadian Center for Architecture

29. MARCEL DUCHAMP, Nú descendo a escada nº 2, 1912.
30. DAVIDSON, Cynthia (org). Tracing Eisenman. New York, Rizzoli, 2006

31. EADWEARD MUYBRIDGE, Woman walking downstairs, 1887

\section{CAPITULO 02}

32. www.zeno.org/Fotografien/B/Marey.

33. LINSKER, Roberto. Mar de homens. São Paulo, Terra Virgem, 2005.

34. OS INCOMPREENDIDOS. Direção: François Truffaut. Fotografia: Henri Decaë. Roteiro: Marcel Moussy, François Truffaut. [Paris] : Les Films du Carrosse, 1959 Manaus, AM : Microservice, 2003. 1 DVD (100 min.), p\&tb. Título original: Les quatre cents coups.

35. Discurso de Hitler em Nuremberg.

36. AD Architectural Design Profile, n.50, 1983.

37. BERLIM, sinfonia da metrópole. Direção: Walther Ruttmann. Alemanha: Fox-Europa Film [produção], 1927 s.l.: Continental Home Vídeo [distribuição], 200-. 1 DVD (77 min.), p\&tb. Título original: Berlin, Die Sinfonie der Großstadt.

38. Über Berlin: Kartenmappe, Berlin von oben. Panorama-Berlin, 2013. 39. George Grosz, Dedicado a Oskar Panizza, 1917-1918.

40. George Grosz, Man is Good, 1920.

40. Über Berlin: Kartenmappe, Berlin von oben. Panorama-Berlin, 2013. 41. Über Berlin: Kartenmappe, Berlin von oben. Panorama-Berlin, 2013.

42. Über Berlin: Kartenmappe, Berlin von oben. Panorama-Berlin, 2013.

43. Google Maps.

4. Google Maps.

45. www.volksbuehne-berlin.de.

45. commons.wikimedia.org/wiki.

46. www.museum-blindenwerkstatt.de.

47. www.statistik-des-holocaust.de/list_ger_ber_ot35.html

48. commons.wikimedia.org/wiki.

49. gerz.fr.

50. gerz.fr 
51. ENDLICH, Stefanie; BUTTLAR, Florian von. "Costruire? Aspettare? Rinunciare?”. Domus, n. 808, out. 1998

52. HEIMROD, Ute; SCHLUSCHE, Günter; SEFERENS, Horst. Der Denkmalstreit - das Denkmal? Die debatte um das "Denkmal für die ermordeten Juden Europas": Eine Dokumentation Berlin, Philo Verlag, 1999.

54. "La Pagina a Berlino in Lindenstrasse, Kreuzberg”. Domus, n. 808, out. 1998

55. "La Pagina a Berlino in Lindenstrasse, Kreuzberg". Domus, $\mathrm{n}$. 808, out. 1998

56. ENDLICH, Stefanie; BUTTLAR, Florian von. "Costruire? Aspettare? Rinunciare?”. Domus, n. 808, out. 1998

57. HEIMROD, Ute; SCHLUSCHE, Günter; SEFERENS, Horst. De Denkmalstreit - das Denkmal? Die debatte um das "Denkmal für die ermordeten Juden Europas": Eine Dokumentation. Berlin, Philo Verlag, 1999.

58. daniel-libeskind.com.

59. daniel-libeskind.com.

60. daniel-libeskind.com

61. ENDLICH, Stefanie; BUTTLAR, Florian von. "Costruire? Aspettare? Rinunciare?”. Domus, n. 808, out. 1998.

62. ENDLICH, Stefanie; BUTTLAR, Florian von. "Costruire? Aspettare? Rinunciare?”. Domus, n. 808, out. 1998.

63. www.topographie.de.

64. www.bild.bundesarchiv.de

\section{CAPITULO 03}

65. LINSKER, Roberto. Mar de homens. São Paulo, Terra Virgem, 2005. 66. notlion.github.io/streetview-stereographic.

67. Über Berlin: Kartenmappe, Berlin von oben. Panorama-Berlin, 2013. 68. Über Berlin: Kartenmappe, Berlin von oben. Panorama-Berlin, 2013.

69. Über Berlin: Kartenmappe, Berlin von oben. Panorama-Berlin, 2013.

70. Über Berlin: Kartenmappe, Berlin von oben. Panorama-Berlin, 2013

71. Über Berlin: Kartenmappe, Berlin von oben. Panorama-Berlin, 2013.
72. Google Maps.

73. Acervo CCA. Foto: Georgia Lobo.

74. Muro dos Nomes no Memorial de la Soah, 2005.

75. Daniel Libeskind, Museu Judaico, 1999.

76. Rachel Whiteread, Judenplatz Holocaust Memorial (Nameless Library), Viena, 2000.

77. George Segal, The Holocaust, San Francisco, 1984.

78. Kenneth Treister, Holocaust Memorial of the Greater Miam Jewish Federation, Miami Beach, 1990.

79. ENDLICH, Stefanie; BUTTLAR, Florian von. "Costruire? Aspettare? Rinunciare?”. Domus, n. 808, out. 1998.

80. ENDLICH, Stefanie; BUTTLAR, Florian von. "Costruire? Aspettare? Rinunciare?". Domus, n. 808, out 1998.

81. HEIMROD, Ute; SCHLUSCHE, Günter; SEFERENS, Horst. Der Denkmalstreit - das Denkmal? Die debatte um das "Denkmal für die ermordeten Juden Europas": Eine Dokumentation. Berlin, Philo Verlag, 1999.

82. EISENMAN, Peter. "Peter Eisenman: Memorial to the Murdered Jews of Europe, Berlin, Germany 1998-2005”. A + U: architecture and urbanism, n. 419, ago. 2005

83. EISENMAN, Peter. DAVIDSON, Cynthia. Tracing Eisenman. New York, Rizzoli, 2006

84. blogs.yu.edu.

85. blogs.yu.edu.

86. BINET, Hélène; RAUTERBERG, Hanno; WASSMANN, Lukas. Holocaust Memorial Berlin. Baden, Lars Müller Publishers, 2005

87. BINET, Hélène; RAUTERBERG, Hanno; WASSMANN, Lukas. Holocaust Memorial Berlin. Baden, Lars Müller Publishers, 2005.

88. Acervo CCA. Foto: Georgia Lobo.

89. ENDLICH, Stefanie; BUTTLAR, Florian von. "Costruire? Aspettare? Rinunciare?”. Domus, n. 808, out. 1998. 
90. SCHLÖR, Joachim. Memorial to the Murdered Jews in Europe. München, Prestel, 2008

91. www.altamurafilms.com.

92. BINET, Hélène; RAUTERBERG, Hanno; WASSMANN, Lukas. Holocaust Memorial Berlin. Baden, Lars Müller Publishers, 2005

93. collections.yadvashem.org/photosarchive/en-us/15362.html.

94. www.ushmm.org.

95. SCHLÖR, Joachim. Memorial to the Murdered Jews in Europe. München, Prestel, 2008.

96. STIFTUNG DENKMAL FÜR DIE ERMORDETEN JUDEN EUROPAS. Materials on the Memorial to the Murdered Jews of Europe. Berlin, Nicolai Verlag, 2005.

97. www.flickr.com/photos/a-weidinger.

98. SCHLÖR, Joachim. Memorial to the Murdered Jews in Europe München, Prestel, 2008.

99. www.cafetorah.com

100. panoramio.com/photo/74306198

101. www.ad.nl/ad/nl/4565/Buitenland/photoalbum/de tail/3561884/484192/27/Sneeuw-in-Jeruzalem.dhtml.

102. DAVIDSON, Cynthia (org.). Tracing Eisenman. New York, Rizzoli, 2006.

103. GIMÉNEZ, Carlos G.; MIRÁS, Marta; VALENTINO, Julio. La arquitetura cómplice. Buenos Aires, Nobuko, 2011.

104. wikimapia.org/35174/Former-Auschwitz-II-BirkenauConcentration-Camp.

106. codoh.com/library/document/2837.

107. www.bing.com/maps.

108. Cova coletiva

109. STIFTUNG TOPOGRAPHIE DE TERRORS. Topography of Terror: Gestapo, SS and Reich Security Main Office on Wilhelm and Prinz Albrecht Strasse: a documentation. Berlin, 2010.
110. STIFTUNG DENKMAL FÜR DIE ERMORDETEN JUDEN EUROPAS. Materials on the Memorial to the Murdered Jews of Europe. Berlin, Nicolai Verlag, 2005.

111. STIFTUNG DENKMAL FÜR DIE ERMORDETEN JUDEN EUROPAS. Materials on the Memorial to the Murdered Jews of Europe. Berlin, Nicolai Verlag, 2005.

112. EIN WEITES Feld. Direção: Gerburg Rohde-Dahl. [S.l.]: RohdeDahl, 2008

113. BINET, Hélène; RAUTERBERG, Hanno; WASSMANN, Lukas. Holocaust Memorial Berlin. Baden, Lars Müller Publishers, 2005.

114. BINET, Hélène; RAUTERBERG, Hanno; WASSMANN, Lukas. Holocaust Memorial Berlin. Baden, Lars Müller Publishers, 2005.

115. Acervo CCA. Foto: Georgia Lobo.

116. Acervo CCA. Foto: Georgia Lobo.

117. Acervo CCA. Foto: Georgia Lobo.

118. STIFTUNG DENKMAL FÜR DIE ERMORDETEN JUDEN EUROPAS. Materials on the Memorial to the Murdered Jews of Europe. Berlin, Nicolai Verlag, 2005.

119. STIFTUNG DENKMAL FÜR DIE ERMORDETEN JUDEN EUROPAS. Materials on the Memorial to the Murdered Jews of Europe. Berlin, Nicolai Verlag, 2005.

120. STIFTUNG DENKMAL FÜR DIE ERMORDETEN JUDEN EUROPAS. Materials on the Memorial to the Murdered Jews of Europe. Berlin, Nicolai Verlag, 2005.

121. STIFTUNG DENKMAL FÜR DIE ERMORDETEN JUDEN EUROPAS. Materials on the Memorial to the Murdered Jews of Europe. Berlin, Nicolai Verlag, 2005.

122. BINET, Hélène; RAUTERBERG, Hanno; WASSMANN, Lukas. Holocaust Memorial Berlin. Baden, Lars Müller Publishers, 2005. 
123. BINET, Hélène; RAUTERBERG, Hanno; WASSMANN, Lukas. Holocaust Memorial Berlin. Baden, Lars Müller Publishers, 2005.

124. Acervo CCA. Foto: Georgia Lobo.

125. Acervo CCA. Foto: Georgia Lobo.

126. Acervo CCA. Foto: Georgia Lobo.

127. Acervo CCA. Foto: Georgia Lobo.

128. Acervo CCA. Foto: Georgia Lobo.

129. Acervo CCA. Foto: Georgia Lobo.

130. BINET, Hélène; RAUTERBERG, Hanno; WASSMANN, Lukas. Holocaust Memorial Berlin. Baden, Lars Müller Publishers, 2005

131. BINET, Hélène; RAUTERBERG, Hanno; WASSMANN, Lukas. Holocaust Memorial Berlin. Baden, Lars Müller Publishers, 2005

132. BINET, Hélène; RAUTERBERG, Hanno; WASSMANN, Lukas. Holocaust Memorial Berlin. Baden, Lars Müller Publishers, 2005. 